ISABELLA BATALHA MUNIZBARBOSA

\title{
O LUGAR NO CONTEXTO DAS REDES GLOBAIS: O POLO INDUSTRIALE DE SERVIÇOS DE ANCHIETA, ES \\ - uma paisagem em transformação
}

Tese a presentada à Faculdade de Arquitetura e Urbanismo da Universida de de São Paulo para obtenção do título de Doutor em Arquitetura e Urbanismo.

Área de Concentração: Paisagem e Ambiente Orientadora: Prof.ạDr.ạMaria Ângela Faggin Pereira Leite

São Paulo

2010 
AUTORIZO A REPRODUÇÃO E DIVULGAÇÃO TOTAL OU PARCIAL DESTE TRABALHO, POR QUALQ UER MEIO CONVENCIONALOU ELEIRỐNICO, PARA FINSDE ESTUDO E PESQUISA, DESDE QUE CITADA A FONTE.

E-MAIL: bella.barbosa@uol.com.br

Barbosa, Isabella Batalha Muniz

B238L O lugar no contexto das redes globais: o Polo Industrial e de Serviços de Anchieta, ES - uma paisagem em transformação / Isabella Batalha Muniz Barbosa. --São Paulo, 2010.

341 p. : il.

Tese (Doutorado - Área de Concentração: Paisagem e Ambiente) - FAUUSP.

Orientadora: Maria Ângela Faggin Pereira Leite

1.Planejamento territorial 2.Globalização 3.Paisagem 4.Estado (Política) 5. Mercados I.Título

CDU 711 
À memória da minha avó, Cecília (1910 - 2009), exemplo de vida. Independente e talentosa, viveu os anos da modernidade e a arte em sua essência. 

Dedico esta tese, em especial, às pessoas queridas do meu cotidiano, pelo apoio incondicional, pela paciência ante a ausência sentida nas solicitações do dia a dia. Sem essa compreensão e esse aporte por parte delas, a realização dessa tese não seria possível:

A Paulo,

Aos meus filhos, Gabriel, Julia e Luisa,

Aos meus pais, Regina e José. 



\section{AGRADECIMENTOS}

À minha orientadora, Professora Dr. ${ }^{a}$ Maria Ângela por compartilhar de sua experiência e de seus conhecimentos; pela dedicação e atenção, críticas e comentários, que possibilitaram o meu amadurecimento na forma de conduzir e estruturar a tese e de evitar os desvios de percurso; enfim, pelo cientificismo que empreendeu à metodologia para que eu avançasse no sentido de qualificar objetivamente a tese.

Aos Professores Drs. Eugênio Queiroga e Maria Monica Arroyo, que compuseram a Banca de Exame de Qualificação, pelas observações e críticas pertinentes, que em muito contribuíram para enriquecer o desenvolvimento da tese.

A todos os professores da área de Paisagem e Ambiente com quem convivi por quase oito anos no cumprimento do Programa de Pós-Graduação - Mestrado e Doutorado -, pelo aprendizado contínuo, pela criatividade e habilidade na docência, sem deixar de fazer menção especial aos Professores Drs. Catharina Lima e Jorge Oseki (in memoriam).

À Professora Dr. ${ }^{a}$ Eneida Maria de Souza Mendonça, do Departamento de Arquitetura e Urbanismo da Universidade Federal do Espírito Santo, pela admiração e pela seriedade com que conduz os assuntos acadêmicos. Incansável, está sempre disposta a contribuir no desenvolvimento dos trabalhos, das dissertações ou teses.

À Diretoria do Instituto Jones dos Santos Neves - Ana Paula Vitali Janes Vescovi (Diretora-Presidente), Andréa Figueiredo Nascimento (Diretora Administrativa), Rodrigo Borrego Lorena (Diretor de Estudos e Pesquisas), pelo apoio no período dedicado à finalização da tese.

À Professora Maria Dalva Marchezi, pelo trabalho de revisão.

A Camila Chicchi e Eugênio Herkenhoff, pelo carinho e pela disponibilidade no trato das imagens e do projeto gráfico. 
Aos meus irmãos, Flávia e Hylson, e demais familiares, Zélia e Guida, que sempre me apoiaram nas horas difíceis.

A Edna, pelo cuidado para com os meus filhos.

Às amigas Esther, Gorete, Vera Carreiro, pela amizade e torcida para a conclusão da tese.

Aos amigos da Pós-Graduação, Peter e Cristiane, pelas trocas e pela solidariedade.

Ao Professor Roberto Garcia Simões, ao Dr. Perseu Carvalho, à jornalista Helena Macedo e demais pessoas que contribuíram com entrevistas e depoimentos.

Aos representantes das Instituições que me apoiaram no período de desenvolvimento desta tese:

Ana Márcia Erler - ADERES.

Adélia Maria Souza - Secretaria de Turismo da Prefeitura Municipal de Anchieta.

Claudimar Marçal - Instituto Jones dos Santos Neves (Dept ${ }^{\circ}$ Estudos Econômicos).

Heloires Nogueira - Instituto Jones dos Santos Neves (Banco de Dados) Hideko Nagatami Feitoza - Especialista em SIG da Unidade Central GEOBASES /IJSN.

Sandra Berredo - Espaço Construtora - Estudos do Plano Diretor Municipal de Anchieta. 
Os novos formatos e significados atribuídos aos lugares perante a globalização têm reflexos expressivos na produção do espaço, assim como no cotidiano. Em face das tecnologias de rede a serem implantadas no território do Espírito Santo, inúmeras variáveis se apresentam como possibilidades de novas formas de organização socioespacial. O objeto empírico da tese é o Polo Industrial e de Serviços de Anchieta (ES) no âmbito das relações estabelecidas entre Estado, mercado e redes globais. A hipótese é a de que as estratégias para efetivação do Polo Anchieta privilegiam os interesses do mercado, o que notadamente compromete os processos socioambientais do espaço coletivo e da paisagem. A redução do território à sua dimensão estritamente econômica rompe, de maneira profunda, a trama das relações estabelecidas historicamente nos lugares de vida. O Estado perde autonomia pública e abre mão do seu papel regulatório ao substituir largamente o planejamento por um imediatismo mercadófilo, beneficiando duplamente as grandes corporações: por um lado, permite a instalação dos objetos técnicos, e, por outro, viabiliza a modernização dos sistemas de engenharia e da logística de transportes, vetores fundamentais para a especialização produtiva do território. A tese investiga ainda as tendências de concentração econômica e tecnológica, preferencialmente no litoral e no entorno da Região Metropolitana da Grande Vitória, direcionadas por um Plano de governo, o que leva ao desenvolvimento desigual das redes de infraestrutura. Com isso, a rede técnica é expandida, mas aprofundamse as diferenças regionais.

Palavras-chave: Planejamento territorial. Globalização. Estado. Mercado. Lugar. Paisagem. 

New formats and meanings assigned to places as a result of globalization markedly influence space production, as well as daily life. In face of the network technologies that are about to be introduced into the Espirito Santo State territory, countless variables are proposed as possible new forms of social and spatial organization. This thesis empirical object is the Polo Industrial e de Serviços de Anchieta (ES) (Anchieta - ES Industry and Service Center) in the context of the relationships established among state, market, and global networks. The hypothesis is that the strategies used to create the Anchieta Industry and Service Center will favor market interests, which will greatly affect common space and landscape, as far as their social-environmental processes are concerned. Reducing the territory to its strictly economic dimension severely breaks up the historically established web of relationships in the living places. The State loses its public autonomy and renounces its ruling role as planning is extensively replaced by a marketing immediacy that will twice benefit the large corporations: on one hand, it allows the set up of the technical objects, and on the other, it makes the modernization of engineering systems and transport logistics feasible, which are fundamental vectors towards the territory productive specialization. This thesis further investigates the economical and technological concentration tendencies, preferably along the coast and surrounding the metropolitan area of Grande Vitória, which are controlled by a government plan and lead to an uneven development of the infrastructure networks. In this way, the technical network is expanded, but the regional differences grow deeper.

Key Words: Territorial planning. Globalization. State. Market. Place. Landscape. 

Figura 1

Figura 2

Figura 3

Figura 4

Figura 5

Figura 6

Figura 7

Figura 8

Figura 9

Figura 10

Figura 11

Figura 12

Figura 13

Figura 14

Figura 15

Figura 16

Figura 17

Figura 18

Figura 19

Figura 20

Figura 21

Figura 22

Figura 23

Figura 24

Figura 25

Figura 26

Figura 27

Figura 28

Figura 29

Figura 30

Figura 31

Figura 32

Figura 33

Figura 34

Figura 35

Figura 36

Figura 37

Figura 38

Figura 39

Figura 40

Figura 41

Figura 42

Figura 43

Figura 44

Figura 45

Figura 46

Figura 47

Figura 48

Figura 49

Figura 50

Figura 51

Figura 52

Figura 53

Figura 54
Carta Altimétrica do Espínito Santo

Localização dos portos no litoral do Espírito Santo.

Cidades-polo isoladas no Espírito Santo do século XIX. $\quad 71$

Companhia Siderúrgica de Tubarão (CST) e respectivo porto. $\quad 77$

Fábrica da Aracruz Celulose.

Plantio de eucalipto no município de Aracruz. $\quad \mathbf{8 1}$

Protesto pela devolução das terras indígenas - Aracruz Celulose. $\quad \mathbf{8 1}$

Protesto contra o desmatamento - Aracruz Celulose. $\quad 81$

Limites territoriais do município de Vitória. $\quad \mathbf{8 8}$

Região Metropolitana da Grande Vitória e os limites territoriais

Uso do Solo da Região Metropolitana da Grande Vitória. $\quad 90$

Distribuição do PIB por microrregião.

Distribuição de renda no Espírito Santo.

Índice de violência do Espírito Santo.

Saneamento Urbano Espírito Santo. $\quad 96$

Rede de cidades contempladas no Plano $2025 . \quad 114$

Distribuição dos Investimentos 2007-2012. 129

Sistema Logístico Goiás-Minas Gerais - Espírito Santo. 121

Logística portuária e de transportes do Plano $2025 . \quad 122$

Esquemático dos projetos logística elencados no Plano 2025. 123

Mapeamento dos campos de petróleo no litoral do ES. 126

Percurso da Unidade de Tratamento de Gás (UTG) sul. 127

Zona Industrial do Polo e as áreas desapropriadas. 142

Polo Anchieta e sua inserção geográfica no Espírito Santo. $\quad 145$

Localização do Polo em relação ao Macrozoneamento PDM 145

Desenho do Polo e respectivo zoneamento. 146

Relativização do perímetro urbano de Anchieta antigo e atual. $\quad 154$

Perímetro Urbano de Anchieta .

Mapa Plano Diretor Municipal de Anchieta e zoneamento. 159

Mapa Plano Diretor Municipal e ZEIAs. 161

As manchetes veiculadas nos jornais capixabas. 177

A região do Pólo Anchieta vizinho à RMGV 195

Divisão Distrital do município de Anchieta. 197

$\begin{array}{ll}\text { Estrutura urbana linear polinucleada. } & 198\end{array}$

Estrutura Fundiária do município de Anchieta. $\quad 200$

Sítio histórico de Anchieta às margens do Benevente. $\quad 213$

Santuário de Anchieta com Igreja e residência anexa. $\quad 214$

Cela do aposento do Beato Anchieta $\quad 214$

Praia de Anchieta e o busto do beato.

Sítio arqueológico de Riritiba. $\quad 214$

O Rio Salinas, tributário do Rio Benevente, que leva às Ruínas. 216

Ruínas do Rio Salinas. $\quad 216$

Mapa Uso do Solo do município Anchieta. $\quad 220$

A baía do Rio Benevente $\quad 222$

O barco, a rede e a pesca, símbolos da tradição local. $\quad 222$

Lagoa Mãe-Bá. $\quad 223$

APA de Guanandy.

Floresta de transição entre o mangue e a Mata Atlântica. $\quad 225$

Falésias em Ubu. $\quad 226$

A criação de parques sugeridos pela Agenda 21 de Anchieta. 226

Monte Aghá, em Píuma visto das praias de Anchieta. $\quad 230$

Monte Aghá destaca-se na paisagem. $\quad 230$

Estação Ecológica do Papagaio em relação ao Pólo. $\quad 242$

Lagoa Mãe-Bá em relação ao Polo. 
Figura 55 Monte Urubu em relação ao Polo.

Figura 56 Distribuição das APP’s no interior do Polo.

$\begin{array}{lll}\text { Figura } 57 & \text { Recursos Hídricos da Microrregião Metrópole Expandida Sul. } & 248\end{array}$

Figura 58 Estudo da construção das barragens na microrregião sul. 250

Figura 59 Partículas Totais em Suspensão (PTS) - Situação atual. $\quad 254$

Figura 60 Partículas Totais em Suspensão (PTS) - Situação com o Polo. 254

Figura 61 Implantação de Wind fence para contenção do pó de minério. 255

$\begin{array}{llr}\text { Figura } 62 & \text { Loteamento Monte Aghá. } & 257\end{array}$

$\begin{array}{lll}\text { Figura } 63 & \text { Censo Imobiliário do setor imobiliário na RMGV. } & 261\end{array}$

Figura 64 A notícia veiculada na mídia: governo estadual veta a Baosteel. 279

Figura 65 Mídia especula: a priorização das atividades petrolíferas. 280

Figura 66 Pátio do Santuário de Anchieta de onde se avista o mar. 311

Figura 67 Escadaria junto ao Santuário - percurso dos jesuítas. 311

Figura 68 Casarão da família Assad na vila histórica de Anchieta. 311

Figura 69 Atracadouro de barcos na baía do Benevente.

Figura 70 Pôr do sol em Anchieta. 
USTA DE TABELAS

Tabela 1 População dos municípios da RMGV - $2008 \quad \mathbf{8 8}$

Tabela 2 População por Macro e Microrregião (ES) - 1991 e 2000

Tabela 3 Distribuição PIB por microrregião 106

Tabela 4 Evolução, número de projetos, do valor total e do valor unitário 108

Tabela 5 Investimentos previstos 2007-2012, PIB 2005 e principais atividades 115

Tabela 6 Investimento do Espírito Santo - PAC 117

Tabela 7 Investimentos PAC por setor de atividade - 2007-2010 117

Tabela $8 \quad$ Principais atividades de investimentos no Espírito Santo 118

Tabela 9 Principais investimentos no Espírito Santo - 2008-2013 129

$\begin{array}{lll}\text { Tabela } 10 & \text { Projetos vinculados ao Polo Anchieta } & 147\end{array}$

Tabela $11 \quad$ População Anchieta $2000 / 2007 \quad 195$

Tabela 12 População, Área e Densidade Demográfica, Micorregião Sul - $2000 \quad 196$

Tabela 13 Taxa de urbanização (\%) Guarapari, Anchieta e Piúna 199

Tabela 14 PIB para a Microrregião Metropolitana Expandida Sul 203

Tabela 15 Produto interno bruto - Município de Anchieta 2005 por setor (\%) 203

Tabela 16 Elementos de destaque meio ambiente - Anchieta 227

Tabela 17 Estimativa de população 2007-2020 - Anchieta 238

Tabela $18 \quad$ Projeção de crescimento da população com Pólo Industrial 238

Tabela 19 Quadro de demandas atuais, vazões e projeções para 2012 e 2018

Gráfico $1 \quad$ Investimentos previstos pelo Plano $2025 \quad 97$

Gráfico 2 Produção industrial estados federados - abril $2009 \quad 270$ 
18 | INTRODUÇÃO 
AAE Avaliação Ambiental Estratégica

ADERES Agência de Desenvolvimento em Rede do Espírito Santo

APA Area de Proteção Ambiental

CST Companhia Siderúrgica de Tubarão

CEFETES Centro Federal de Educação Tecnológica do Espírito Santo

ES Espírito Santo

GAMA Grupo de Apoio ao Meio Ambiente

IBGE Instituto Brasileiro de Geografia e Estatística

IEMA Instituto Estadual do Meio Ambiente

IJSN Instituto Jones dos Santos Neves

IPHAN Instituto do Patrimônio Histórico e Artístico Nacional

PDM Plano Diretor Municipal

RMGV Região Metropolitana da Grande Vitória

SEP Secretaria de Estado de Economia e de Planejamento

SETADES Secretaria de Estado do Trabalho, Assistência e do Trabalho.

SNUC Sistema Nacional de Unidades de Conservação

TAC Termo de Compromisso de Ajuste de Conduta

UFES Universidade Federal do Espírito Santo 
20 | INTRODUÇÃO 
INTRODUÇÃO 25

\section{PARIE I: A Globalização como processo; o Tenitónio como instrumento 35}

CAPÍTULO 1 - PLANEJ AR E GERIR O TERRITÓ RIO NA GLOBALIZAÇÃO 37

1.1 As fronteira s não impõem limites às redes téc nic as $\mathbf{4 4}$

1.20 Temitónio: estruturação na escala local, regional e nacional $\mathbf{5 0}$

CAPÍTULO 2 - O TERRITÓRIO COMO SUPORTE DO SISTEMA DE OBJ ETOSE DEAÇÕES 61

2.1 Da ação dos homens 64

2.2 A tec nific ação e a constituição desigual do temitório do Espínito Santo 75

2.2.1 A especialização e centralidade da RMGV 85

PARIE II: Especialização produtiva e preparação do Temitónio 101

CAPÍTULO 3 - O PLANO 2025 - ESTRUTURAÇÃO E ESTRATÉG IAS 103

3.1 Diretrizes de desenvolvimento 109

3.1.1 Desenvolvimento da rede de cidades $\mathbf{1 1 1}$

3.1.2 Desenvolvimento da logística e de circulação de mercadorias $\mathbf{1 2 0}$

3.1.3 Imagem e comunic ação do Plano $\mathbf{1 3 0}$

3.2 As interfaces entre Estado e mercado: o movimento empresarial "ES em Ação" 131

CAPÍTULO 4 - O POLO INDUSTRIAL E DE SERVIÇ OS DE ANCHIETA 139

4.1 Localização e área de influência 144

4.2 Desenho Conceitual do Polo $\mathbf{1 4 7}$

4.3 Plano Diretor Municipal respa Ida o Polo? $\mathbf{1 5 0}$

CAPÍTULO 5 - O DISCURSO EA PRÁXIS INVERTIDA 167

5.1 A retórica e o mito da "sustentabilidade" 179

PARIE III: O Pólo conectando o Lugar ao Mundo 185

CAPÍTULO 6 - ANCHIETA: UM LUGAR DO MUNDO 187

6.1 As dinâmic as socioespacia is na região de influência do Pólo 194

6.1.1Saneamento Básico 204

6.1.2 do sistema viário 206

6.2 A paisagem e os objetos loca Imente qua lific ados 209

6.2.1 Ec ossistemase ambiente urbano $\mathbf{2 1 8}$ 


\section{CAPÍTULO 7 - RISCOSE VULNERABILDADESDO POLO 235}

7.1 Sobrecarga na estrutura física e social $\mathbf{2 3 6}$

7.2 A questão a mbiental 243

7.2.1 Água: imprescindível para o funcionamento do Polo $\mathbf{2 4 7}$

7.2.2 A emissão de poluentes tende a aumentar 253

7.2.3 O turismo ameaçado 256

7.2.4 O boom imobiliário na região do Polo e reflexos na RMGV 260

CAPÍTULO 8 - OSCENÁRIOS ANTE AS FLUTUAÇÕESDA ECONOMIA MUNDIAL 265

8.1 Os resultados da AAE e a saída da Boasteel 271

CAPITUULO 9 - AS INTERVENÇÕES: COTIDIANO E IMAGINÁRIO SOCIAL 287

CAPÍTULO 10 - UMA REFLEXÃO: E COMO FICA A PAISAGEM? 303

CAPÍTULO 11 - CONSIDERAÇÕ ES FINAIS: O Futuro do Lugar 315

REFERÊNCIAS 325 
Pensar é viver. Viver é pensar. Não há pensamentos sem riscos. Não há pensamento que não seja um afrontamento pessoal com o mundo. Pensar também é esbarrar no precipício, assumir o desespero e a solidão que possam resultar do pensamento. Pensar é se expor.

Hannah Arendt (journal de pensée, 1950) 



\section{INTRODUÇÃO}

$\mathrm{Na}$ atualidade, nosso meio de pensar a sociedade contemporânea é a noção de rede, mais flexível que a noção de sistema, mais histórica que a de estrutura. A rede é o fio condutor que integra e desafia todas as epistemologias. As redes técnicas se realizam, tornando-se história, com a intermediação das empresas e do Estado ${ }^{1}$. Na medida em que um lugar ou determinada porção do território se torna um grande negócio para o capital global, as leis de mercado passam a ditar as regras do ordenamento e da configuração socioespacial que se consolidam pelo ato jurídico. Das possibilidades da ação, emerge o planejamento, como instrumento técnico para a superação dos problemas e a concretização das metas. A forma clássica e óbvia do planejamento é o plano, viabilizando uma dada estratégia de desenvolvimento e preparando o território para recepção das redes técnicas: o plano como um resultado das relações de poder que nele encontrarão expressão concreta. Esta tese não se restringe, porém, apenas ao contexto social do planejamento e aos interesses do poder, mas focaliza também o envolvimento com os coletivos, com os objetos e com os sujeitos.

O planejamento tem que acordar com a ideia de que a irreversibilidade da globalização é um fato do qual não se pode mais escapar, assim como é indiscutível a interdependência entre a história geral, coletiva, e as histórias particulares. A globalização, ao assinalar a existência de um outro tempo, que é o tempo da ressignificação dos conteúdos, dos novos nexos que rearticulam as inscrições do vivido, aciona também o movimento das dimensões pulsantes e desejadas. Na mistura dos tempos, as marcas da história, os eventos, condensam-se, deslocam-se e criam novos sentidos. A história do sujeito contemporâneo não é, portanto, uma linha reta, mas é traçada por pontos de condensação nos quais as tramas do vivido se entrecruzam e pulsam, no passado e no presente, no local e no global. Ao tentar transpor essas redefinições do domínio da subjetividade para o da história coletiva e do território para o plano global, encontramos muitas dificuldades. Hoje, o que está sendo privilegiado são as relações pontuais entre os grandes atores globais; no entanto, muitas vezes, falta sentido de cognição às ações por

$1 \mathrm{Na}$ tese, o uso da palavra "Estado" em letra maiúscula faz referência à instância do poder político; e "estado" em letra minúscula refere-se a unidade territorial federativa. 
eles comandadas nos lugares de vida. Como enfrentar os discursos que partem do pressuposto (na origem iluminista) de que a história sempre avança em direção a um progresso tão certo quanto indefinido e cambiante? O entendimento da dialética inerente à questão talvez resida na crença de que a articulação histórica do passado é inseparável daquela escrita agora, no presente. Não se trata, então, de adquirir um conhecimento isento, dito objetivo, do passado, mas de articular passado e presente de tal maneira que ambos sejam transformados em visões pautadas pela existência.

No contexto atual de aparente instabilidade, em que as superestruturas se interpõem e se sobrepõem às microestruturas, falar do meu interesse no objeto empírico da tese, a princípio, parece um pouco complexo, especialmente em se tratando de um lugar com uma construção coletiva específica, carregada de configurações culturais e simbólicas, cuja paisagem e sociedade estão ambas sob domínio da economia globalizante e em vias de significativas mudanças. A planificação espacial que será discutida ao longo desta tese não é capaz de dar conta da dialética do espaço, quanto mais de superá-la, considerando que, em geral, a concepção do planejamento está imbuída de um discurso ideológico repleto de contradições que contrasta com o espaço concreto, o do habitar: gestos e percursos, símbolos e sentidos, conflitos entre desejos e necessidades.

Em 2007, eu havia acabado de retornar ao Espírito Santo após um longo período de ausência morando no estado de São Paulo, onde desenvolvia atividades acadêmicas ligadas ao Programa de Pós-Graduação da FAU/USP. Interessante que, ao chegar, logo percebi um movimento intenso acerca de um assunto que, até então, era para mim desconhecido e que permeava diversos segmentos da sociedade. Diariamente, e de forma enfática, o assunto circulava na mídia: o Polo Industrial de Anchieta. Naquele momento, ante um objeto técnico de tal magnitude, que suscitava sentimentos ambíguos na sociedade capixaba, tanto de êxtase quanto de estarrecimento, algo de enigmático impulsionava a minha capacidade de compreensão para a contextualização do objeto, no lugar e no mundo. A importância do significado é o que estava buscando. $\mathrm{O}$ assunto foi despertando o meu interesse quase que de imediato, uma vez que o Polo Industrial e de Serviços de Anchieta, além de ser um empreendimento ambicioso, consolida as parcerias entre o Governo do Estado do Espírito Santo e o setor privado e carrega, em 
seu bojo, incongruências que se explicitam à medida que se aprofunda $\mathrm{o}$ conhecimento das questões que o envolvem.

O Polo Industrial e de Serviços foi criado pelo Governo do Estado por decreto de utilidade pública (n¹247-S/2007), no distrito urbano de Anchieta, e tem na siderurgia o seu projeto-âncora, o que requer ainda empreendimentos paralelos de logística para sua operacionalização. O Polo tem por objetivo oferecer condições na criação de vantagens competitivas das atividades desenvolvidas no seu interior que possam ampliar a inserção do Espírito Santo no contexto das redes técnicas globais. Os critérios para seleção e organização de locais que respondam às crescentes necessidades das redes técnicas obedecem a objetivos quantitativos de expansão da produção que, em geral, emergem de considerações imediatas ou de curto prazo. A escolha de Anchieta para sediar o Polo Industrial se deu por alguns aspectos considerados estratégicos para o bom funcionamento do empreendimento, do ponto de vista da localização, tais como a vocação portuária, aliada ao desempenho da atividade siderúrgica e ao fato de o local facilitar a exploração do petróleo via gasoduto.

Mediante questionamentos que iam surgindo, passei a refletir sobre o objeto de interesse por outros vieses, indagando quando e a partir de que premissa se atribui valor e significado a determinado objeto. A princípio, depareime com a possibilidade desse interesse ter sido manifestado pela nostalgia acionada pelo imaginário, ou seja, uma forma de pensamento que se afasta do real e se apoia na percepção e na memória. Considerando o contexto do lugar, são relevantes os aspectos de sua paisagem natural entrecortada por praias, lagoas, rios e mangues, enriquecidos pelo patrimônio histórico, artístico e cultural. Dentre outras razões, especulei se a razão do interesse não poderia ter sido também causada pelo receio de que a paisagem singular de Anchieta, captada em determinado instante por imagens desiderativas e bucólicas do lugar, pudesse estar literalmente na iminência de se encerrar ante o panorama impactante dos projetos previstos para o Pólo Industrial. Estas talvez pudessem ter sido as razões iniciais para as quais eu estivesse sendo instigada a estabelecer uma interlocução com o objeto de estudo.

No decorrer do processo, várias questões ambivalentes foram sendo por mim incorporadas. Um tanto quanto provocativas e instigantes, as questões que envolvem o Polo Industrial de Anchieta foram capazes de 
permitir o deslocamento de um interesse manifestado inicialmente para o desenvolvimento da tese, o qual a princípio, estaria focado na investigação da construção imagética do urbano capixaba, da orla ao mangue, dando continuidade à pesquisa já empreendida na minha dissertação de Mestrado $(2005)^{2}$. Essa pesquisa já destacava, dentro de uma perspectiva histórica, o “projeto de modernização” da Região Metropolitana da Grande Vitória (RMGV), vinculado diretamente ao planejamento estratégico do Estado, que, no modelo desenvolvimentista de industrialização dos anos 1970/1980, já visava atender às demandas da economia internacional.

Os estudos mostraram que a parceria entre setor público e privado foi o principal vetor da expansão da Grande Vitória na primeira fase de industrialização do Espírito Santo. Essa parceria interferia sistematicamente na formação do mercado imobiliário de terras urbanas, revelando uma gama de conflitos no uso e na ocupação do solo, o que resultou num processo de segregação socioespacial e na fragmentação de áreas ambientalmente sensíveis. Busquei, assim, identificar o papel do poder público como elemento estruturador do espaço e da especialização do território, tendo como eixo de abordagem a Baía Noroeste de Vitória. Ao se pensar o Polo Anchieta, não há como desvinculá-lo da experiência com a primeira fase de industrialização no Espírito Santo, que gerou uma série de conflitos de cunho ambiental e social. Ainda hoje, o processo tecnológico do Espírito Santo, associado à disseminação das políticas neoliberais, tende a privilegiar as relações de mercado, especialmente aqueles setores considerados estratégicos para consolidação do comércio exterior com base na siderurgia.

Esta tese de doutorado visa dar continuidade às pesquisas já empreendidas no Mestrado, ampliando o contexto metropolitano para a dimensão regional, tendo como tema central a implantação do Polo Anchieta no âmbito das estratégias formuladas pelo Plano 2025 do Governo do Estado do Espírito Santo. Observa-se que a eleição de um lugar para receber os objetos técnicos tem sido cada vez mais pautada não somente pelas condições locais oferecidas, mas preferencialmente pelos circuitos internacionais de produção que se estruturam num âmbito maior, global, para depois incidirem na escala do lugar. Há, na concepção do Polo Anchieta, um contexto 
de supervalorização das questões relativas ao mercado dentro do qual se dá uma forma específica de construção e apropriação da paisagem sobre a qual símbolos e significados sociais se alteram ou adquirem novos valores.

A macroeconomia política e suas instâncias contêm seus mecanismos de regulação, ou seja, do que é permitido (uso industrial) e do que possa ser explorado (as belezas naturais e o sítio histórico). Os próprios instrumentos normativos geridos pelo poder público - Planos Diretores Municipais e Plano 2025 - interferem na estruturação do território, e com frequência, instituem dispositivos legais geradores de conflitos. O decreto estadual que cria o Polo Industrial assim como o próprio zoneamento do Plano Diretor Municipal de Anchieta dispõem sobre grande área destinada ao uso industrial, contígua às áreas ambientalmente sensíveis. O tema da tese emerge, portanto, das indagações e conflitos gerados no próprio seio do planejamento. Em que medida a especialização produtiva e a tecnológica, a despeito de geração de empregos e arrecadação tributária gerados, privilegiam as relações de mercado e promovem a alienação dos lugares de vida, moldando comportamentos e eliminando tradições e hábitos culturais? Ante a economia global, o planejamento, em vez de atuar como mediador, torna-se gerador de conflitos? Nessa perspectiva analítica, a tese procura investigar a forma como o espaço estratégico dialoga com o espaço natural e como a mediação entre ambos irá configurar novas estruturas de urbanidade.

Outra hipótese que a tese procura investigar é a de que, apesar das intenções manifestadas no Plano 2025 com a criação de polos de atração regional, como o Polo de Anchieta, a Região Metropolitana da Grande Vitíoria (RMGV) deverá continuar a comandar a centralidade econômica, cultural e de serviços em relação às demais regiões. Com a inserção mais proeminente nas redes globais e a ampliação de mercados, configura-se uma tendência ao adensamento de tecnologias nos municípios adjacentes à região metropolitana. Uma das indagações fundamentais, consiste em averiguar em que medida a criação de vários centros ou "rede de cidades polo" passa por um processo social de disputa entre grupos e instituições privadas, que têm um papel importante na redefinição e recomposição da centralidade no contexto contemporâneo. Como essa combinação de interesses pode levar tanto à revalorização da RMGV, quanto, ao mesmo tempo, redirecionar a economia com a constituição de novos eixos de centralidade como o Polo Industrial 
de Anchieta? O movimento, claramente observado, dos investimentos nas duas regiões litorâneas que fazem limite com a RMGV indica a possibilidade futura de conurbação entre elas, ampliando-se e estendendo-se o que seria hoje a região metropolitana. Os investimentos continuam concentrados e direcionados para a Região Metropolitana e em seu entorno imediato, na costa litorânea dos municípios adjacentes.

Com base na abordagem conceitual acerca das categorias analíticas do espaço _o território, o lugar e a paisagem, sobre os quais direcionei os meus estudos no programa de pós-graduação da FAU/USP-, reconheci, no Pólo Industrial e de Serviços de Anchieta, o estudo de caso que possibilitava apoiar as minhas argumentações em teorias de autores já consagrados, em especial, no arcabouço teórico de Milton Santos, cuja fundamentação converge para a capacidade de percepção do movimento dialético do mundo e respectivo rebatimento nos lugares de vida.

Importante resgatar o particularismo do lugar, ressaltando premissas básicas do componente socioambiental, junto aos processos técnicos e projetuais que imprimem materialidade e forma ao território e à paisagem. É no lugar que o espaço e o tempo mundiais são indissociáveis e onde a configuração do sistema técnico se revela. A escolha dos aspectos qualitativos e respectivas escalas de abordagem, nem sempre é fácil, ou seja, selecionar alguns aspectos e abstraí-los dos demais, porque há inúmeras possibilidades críticas de construção das análises qualitativas, considerando que, ações e objetos são interdependentes e conformam a complexidade das estruturas existentes. A mediação entre um subsistema e um sistema global é indispensável, mas a análise se torna inconsistente se não observada as razões sociais as quais fazem com que os homens adotem comportamentos que conduzam a mudanças no espaço.

Para mensurar possíveis impactos que um objeto técnico de magnitude possa imprimir num pequeno lugarejo, há que se definir alguns indicadores necessários que possam dar conta de estimar a capacidade de suporte atual do município no atendimento às demandas potenciais a serem geradas pelo Polo Industrial. Os dados e indicadores referentes à economia, dinâmica populacional, infra-estrutura e o sistema viário são relevantes para avaliação da reprodução e ampliação da estrutura urbana, observados o grau de consolidação e de carência em face da perspectiva de aumento considerável 
das demandas. Não que se vá proceder a um levantamento detalhado desses aspectos, mas, pelo menos, buscar um panorama reflexivo da situação atual. A análise relacional se torna imprescindível. Além das análises das condições urbanísticas e socioespaciais dos municípios diretamente atingidos pelo Polo Industrial, imprescindível reconhecer o vínculo substancial estabelecido entre homem e natureza, aquilo que comumente se denomina ecossistemas urbanos. Assim, situam-se os objetos localmente qualificados que interagem no espaço. De posse de um diagnóstico sintético das dinâmicas socioespaciais e estruturas de suporte, prospectar um cenário de futuro ante a imbricação do lugar às redes técnicas.

Os dados se baseiam no levantamento das principais fontes secundárias das estatísticas oficiais, de modo a compatibilizá-las num universo analítico convergente e próximo da realidade. Em geral, as publicações de dados oficiais privilegiam as regiões metropolitanas em detrimento das bases municipais. Apesar dessa lacuna, tentou-se chegar o mais próximo possível de um diagnóstico que espelhe as principais dimensões das dinâmicas dos municípios que compõem a microrregião sul, e em especial, o município de Anchieta. Além da análise empreendida com base nos dados censitários, algumas informações relativas às principais atividades econômicas municipais com agregados de emprego e renda foram obtidas do Cadastro Central de Empresas (Cempre) ${ }^{3}$, um levantamento realizado pelo IBGE, disponível para o período de 1996 a 2005, além dos dados fornecidos pela SETADES ${ }^{4}$. Outras fontes também foram pesquisadas para levantamento de indicadores, tais como, os documentos da Agenda 21, os estudos do Plano Diretor Municipal, o documento "Perfil de Anchieta" elaborado pelo Instituto Jones dos Santos Neves (IJSN) ${ }^{5}$ e Avaliação Ambiental Estratégica do Pólo Industrial de Anchieta (2008).

Quanto às escalas de abordagem, pelo porte dos investimentos previstos no Polo, os impactos terão repercussões em toda a região sul do estado com reflexos para a Região Metropolitana da Grande Vitória, assim como também, para o território estadual, tendo em vista novas formas de articulação entre as redes de cidades. Com a implantação do Polo, passa-se a

3 A base de dados do Cempre são as empresas e unidades locais formalmente constituídas, registradas no CNPJ (Cadastro Nacional de Pessoa Jurídica).

4 Secretaria de Estado do Trabalho, Assistência e Desenvolvimento Social (SETADES)

5 O Instituto Jones dos Santos Neves (IJSN) está vinculado à Secretaria de Estado de Economia e Planejamento do Espírito Santo (SEP). 
verificar de que forma as estruturas urbanas que integram a microrregião do litoral sul se relacionam e como também são impactados pelo Polo. O foco da análise recai sobre os municípios diretamente afetados, Anchieta, Púuma (Microrregião Expandida Sul) e Guarapari (R.M.G.V), observandose a interação dos processos espaciais estabelecidos entre eles, bem como, as articulações existentes entre o Polo e as respectivas cidades. Procura-se, assim, explicitar a formação econômica da região, seus principais ciclos produtivos, as diferenças e similaridades.

A linha argumentativa desta tese se apoia na ideia de que as representações produzidas por uma cultura estão em constante intercâmbio e respondem aos conflitos por meio de processos e linguagens distintos, existindo, assim, a possibilidade de se trabalhar conjuntamente a interpretação dos fenômenos globais e locais. Graças a seu poder de síntese, o conflito possui a propriedade de integrar os cidadãos em uma temática ampla e de rever os fatos que se sucedem no tempo e no espaço. A configuração do território em questão está, portanto, vinculada ao real pelos símbolos culturais e pelos modos concretos da ação. Essas duas questões são, na verdade, indissociáveis.

Como os lugares não se realizam independentemente dos fluxos, a representatividade espacial do lugar - Anchieta - bem como todo o seu funcionamento enquanto sistema e produtor dinâmico da herança histórica e cultural que se configura na paisagem justificam um esforço de síntese para a compreensão da dinâmica das redes técnicas em relação ao contexto local. A tese dialoga com essa perspectiva de abordagem, ou seja, a compreensão da história inserida num amplo processo de produção globalizante, comunicação e recepção de fatos e significados que afetam a vida cotidiana. Nessa busca, é preciso refletir sobre conceitos que fundamentam as práticas da produção espacial contemporânea, que se descortinam na paisagem, e, por meio deles, tentar explicar as estruturas “invisíveis”, ou seja, aquilo que está oculto por trás dos fenômenos.

Considerando o processo de urbanização historicamente vinculado ao modo de produção capitalista, há que se destacar também a importância do caráter histórico do Estado na constituição do espaço e as relações que ele estabelece com grandes empresas no contexto global. A fundamentação teórica passa necessariamente pela interpretação do meio técnico-científicoinformacional (SANTOS; SILVEIRA, 2005) como forma de ampliação e 
sustentação do processo capitalista de produção. A partir da abordagem conceitual, é possível uma reflexão sobre as estratégias e ações referentes à implantação do Polo Anchieta, que incidem diretamente no lugar - Anchieta (ES) - e no território - o estado do Espírito Santo. A tese pressupõe o entendimento da questão, considerando o espaço como instância social, a globalização como processo, o território como instrumento e os lugares como protagonistas das ações globais. Está dividida em três partes:

Parte I - A Globalização como processo; o Território como instrumento. A primeira parte da tese nos remete aos questionamentos atuais sobre as condições intrínsecas da globalização, e sobre como essas condições favorecem, ou não, as possibilidades de ordenação dos territórios quando considerados imersos em contextos que não mais operam somente mediante limites físicos estabelecidos por fronteiras. Para tanto, é necessário resgatar conceitos sistematizados pela Geografia, que possam auxiliar na compreensão da inserção econômica do estado do Espírito Santo nas redes globais e de como se dão as manifestações locais para essa nova realidade. O referencial teórico refere-se ao planejamento das ações no contexto da globalização e à responsabilidade do Estado na articulação das políticas públicas de ordenamento territorial, sem deixar de considerar novos vínculos associados ao território.

Vale ressaltar que mesmo sendo o Polo Anchieta o objeto empírico da tese, seus reflexos se estendem para além dos limites oficiais do próprio município, sendo relevantes alguns condicionantes históricos representativos do estado do Espírito Santo como um todo, onde o território evoluiu de forma diferenciada em conformidade com as sucessivas ações que nele se estabeleceram. Resgatam-se ainda nesta primeira parte, as ações pautadas na construção socioespacial do território, as quais, historicamente, comandaram a efetivação da Região Metropolitana da Grande Vitória como centralidade econômica e tecnológica.

Parte II - Especialização produtiva e preparação do Território. A segunda parte se refere à dinâmica particular do território do Espírito Santo no âmbito do planejamento estratégico contemporâneo e da globalização. Aqui são apresentadas as diretrizes do planejamento de longo prazo do Governo do Estado do Espírito Santo - o Plano 2025 -, que permitiram respaldar a criação do Polo Industrial de Anchieta. A abordagem das estratégias 
de articulação das parcerias pública e privada e do processo de inovação tecnológica, particularmente aquele relacionado à fluidez do território por meio da logística estabelecida entre sistemas de transporte / tecnociência / comunicação / informação, é central para a construção da linha argumentativa da tese. Tratar-se-á, também, do discurso inerente ao planejamento na preparação do território para a implantação das redes técnicas e aos aspectos intrínsecos relacionados a esse discurso. Nessa perspectiva, buscar-se-á compreender como os próprios recursos do discurso procuram responder, com uma determinada técnica e sentido da imaginação, aos conflitos de ordem socioespacial e a construção de uma base ideológica favorável à reprodução dos interesses corporativos.

Parte III - O Lugar e a imbricação às redes técnicas - Esta terceira parte se refere à categorização do lugar - Anchieta - no contexto da Microrregião Metrópole Expandida Sul no qual se insere, abordando aspectos relativos à configuração histórico-cultural e à estrutura de suporte do município com respectivas dimensões analíticas. Partindo do pressuposto de que o espaço carrega em si um conteúdo material e imaterial ao longo do processo de sua formação, as ações que envolvem o Polo Anchieta requerem uma reflexão sobre os desdobramentos do quadro atual, ou seja, um esforço de prognóstico acerca de possíveis impactos que objetos técnicos, e notadamente econômicos, possam causar nos lugares protagonistas do processo e que incidem diretamente no cotidiano. Criam-se assim, condições objetivas de investigar, qualificar e monitorar o ambiente cotidiano em via de transformação. Na parte III se procede à apresentação dos condicionantes socioespaciais e dos ecossistemas, destacando-se as áreas legalmente protegidas, para num segundo momento, avaliar os fatores críticos e/ ou de risco os quais estas estruturas estão submetidas. A abordagem do Pólo como objeto de articulação entre o lugar - Anchieta - e o mundo, introduz a discussão sobre a redefinição do lugar como expressão mundial, visto que o processo produtivo dá-se também fora das fronteiras do lugar específico. Neste cenário de complexidade, vale ressaltar a pertinência do conteúdo simbólico dos objetos inerentes à paisagem de Anchieta no imaginário social, revelando a importância do valor estético e cultural que atribui sentido de existência ao lugar. 


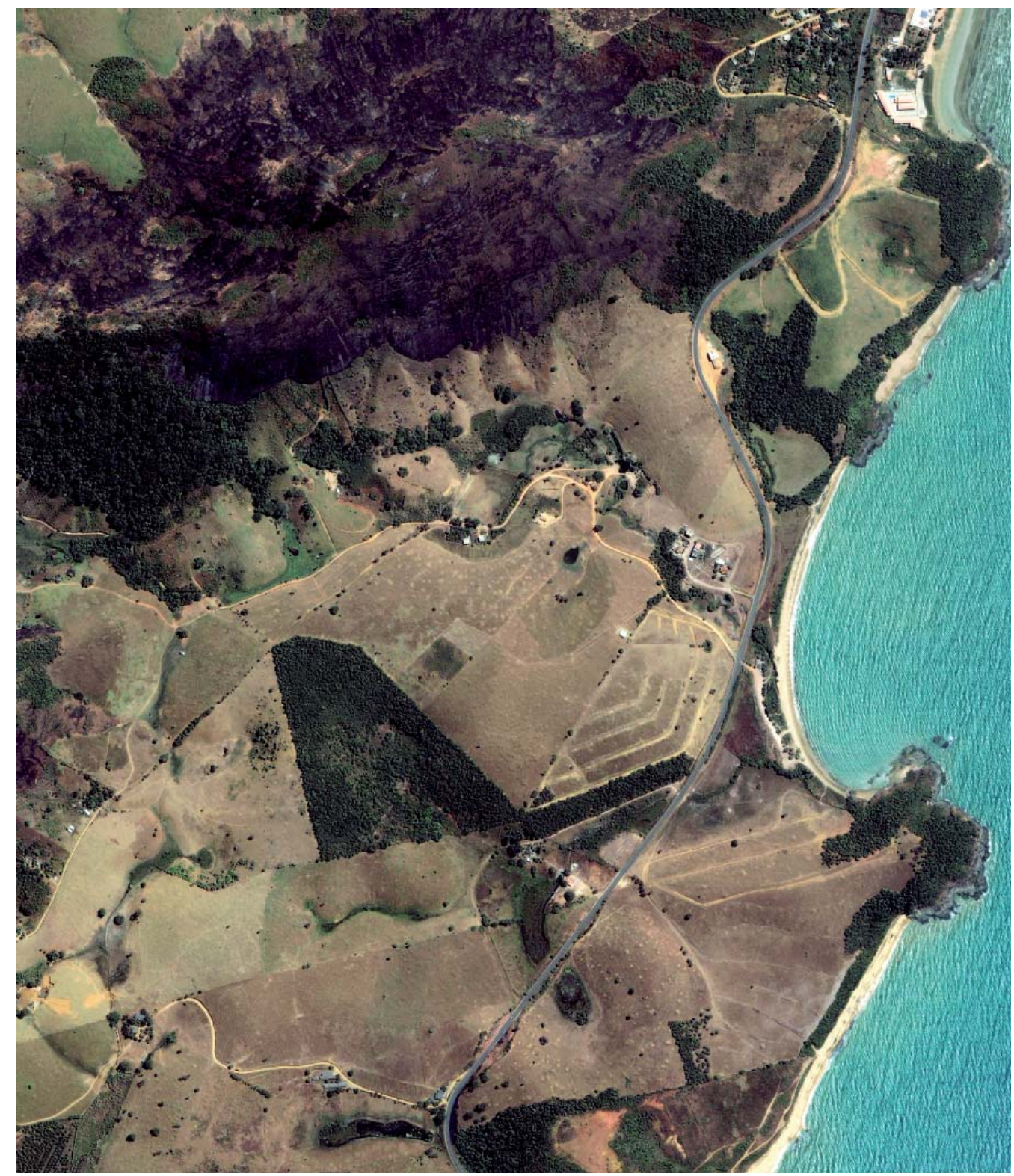

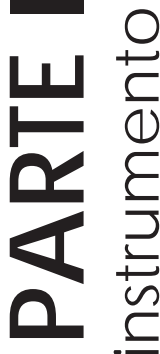

हำ

$\cup$

은

0

8

(1)

$\cup$

?

응

U

O

$2 \pi$

Un

N

O sistema técnico dominante no mundo de hoje tem uma outra característica, isto é, a de ser invasor. Ele não se contenta em ficar ali onde primeiro se instala e busca espalharse, na produção e no Território. Pode não o conseguir, mas essa é a sua vocação. 

38 | CAPÍtULO 1 
Todo projeto de transformação da sociedade pressupõe apreender a complexa estrutura das práticas espaciais e temporais. Compreender a lógica espacial com que novas tecnologias incidem sobre uma determinada região ou lugar passa pelo entendimento das relações históricas e seu rebatimento no território, com a intermediação do Estado, das demais instituições e do conjunto de agentes da economia. Cada época se molda em função dos processos hegemônicos que a lideram, e cada lugar sofre importantes modificações qualitativas advindas desses processos, conforme os condicionantes existentes.

Para os limites desta tese, ou seja, a análise sobre como o recorte territorial (o lugar) se insere num contexto global e sobre o rebatimento dessa inserção nas questões cotidianas, torna-se imperativo avaliar as mudanças associadas aos movimentos e às configurações de maior complexidade nesse quadro de dispersão de fluxos com que se defrontam as unidades territoriais na atualidade. O lugar, espaço da concretização das possibilidades do mundo, não pode mais ser explicado em si mesmo, mas somente a partir de uma lógica que envolve as relações globais mediadas por objetos e sistemas técnicos. Assim, algumas contextualizações teóricas devem ser relembradas para nortear o entendimento das ações no mundo contemporâneo.

A história da mudança social é, em parte, apreendida pela concepção do espaço e do tempo. Na perspectiva materialista, as concepções do tempo e do espaço são criadas necessariamente por meio de práticas e processos materiais que servem à reprodução da vida social (HARVEY, 1989, p.189-208). No processo de produção capitalista, a organização espacial eficiente e o tempo de giro são condicionantes fundamentais que servem de medida à busca da lucratividade - e ambos estão sujeitos a mudanças. Para Santos (1979), "as modificações do papel das formas conteúdo - ou simplesmente da função cedida à forma pelo conteúdo - são subordinadas, e até determinadas, pelo modo de produção tal como ele se realiza na e pela formação social” (SANTOS, 1979, p.17). Assim, há toda uma história de inovações técnicas e organizacionais que visam colocar no centro da 
modernidade capitalista a aceleração do ritmo dos processos econômicos e, em consequência, da vida social. Portanto, trata-se aqui de desvendar as relações espaço/tempo no mundo contemporâneo. A mediação dessas relações é dada pela técnica, que implica transformações profundas na reprodução das relações sociais, provocadas pela aceleração das ações.

Hoje, temos uma nova forma de organização social, que se viabiliza pela tecnologia e pela informação. A globalização, se observada em suas implicações simultaneamente econômicas, políticas e culturais, constitui-se como nova experiência, abrangente e contraditória, como um processo que adquire predominância crescente no mundo contemporâneo sobre as formações sociais, seja locais, nacionais, seja regionais. Muitas disciplinas estão empenhadas em compreender e explicar as novas situações, os acontecimentos e as rupturas assim como as relações que engendram estruturas que se transformam com a sociedade global e se revelam no espaço. Há várias interpretações formuladas acerca da natureza do espaço, mas, diante do interesse em compreender como se dão as relações ante a complexidade do processo de globalização, ative-me, preferencialmente, à abordagem teórica de Milton Santos. O autor argumenta que o espaço é o resultado do casamento indissolúvel entre sistemas de objetos e sistemas de ações (SANTOS, 1994, p.43). Todo objeto pressupõe uma técnica que permite atuar sobre a materialidade e se consolida por meio do trabalho humano. Partindo desse pressuposto, a técnica é elemento fundamental na intermediação entre esses dois sistemas, objetos e ações.

A construção e a reprodução do cotidiano na contemporaneidade têm por base a ideia de que as relações sociais são regidas por um conjunto de objetos cada vez mais técnicos e artificializados. A noção de objeto técnico será central na tese e, para tanto, é pertinente apresentar a proposição conceitual de Seris (Apud SANTOS,1994, p.22): “será objeto técnico todo objeto susceptível de funcionar, como meio ou como resultado entre os requisitos de uma atividade técnica." E é justamente na forma como se estabelecem as relações entre objetos e ações que se procura um sentido para a reafirmação dos valores sociais.

Os objetos técnicos estão presentes praticamente em todos os lugares. O objeto é científico graças à natureza de sua 
concepção, é técnico por sua estrutura interna, é científicotécnico porque sua produção e funcionamento não separam técnica e ciência. E é, também, informacional porque, de um lado, é chamado a produzir um trabalho preciso - e de outro lado, funciona a partir de informações.

SANTOS (2008, p.215)

As novas tecnologias alteram as relações de produção e consumo e implicam uma nova concepção de espaço-tempo e mesmo das identidades culturais mescladas. O chamado mercado global se impõe e procura instalar sua vocação de expansão mediante processos que levam à busca da unificação nas diversas escalas territoriais. Poderíamos chamar de "macroatores" àqueles que de fora da área, determinam as modalidades internas da ação. Santos (2008,p.28) distingue dois períodos relativos à difusão de tecnologias no Brasil: o primeiro, que ele denomina de "meio técnico-científico", que se caracteriza pela revolução das telecomunicações no Brasil; o segundo período, ele denomina de "técnico-científico-informacional", e nesse período, os sistemas de informação e finanças passam a configurar uma nova geografia com base na aceleração dos fluxos . Assim, a globalização deve ser encarada a partir de dois processos paralelos: de um lado, dá-se a produção da materialidade, ou seja, das condições materiais que nos cercam e que são a base da produção econômica, dos transportes e das comunicações. De outro há a produção de novas relações sociais entre países, classes e pessoas (SANTOS, 1994,p.43).

No plano global, as ações constituem normas de uso dos sistemas localizados de objetos, enquanto no plano local, o território, em si mesmo, constitui uma norma para o exercício das ações (SANTOS,1994,p.43). A partir dessas duas ordens, constituem-se, paralelamente, uma razão global e uma razão local que, em cada lugar, se superpõem e, num processo dialético, tanto se associam quanto se contrariam. É nesse sentido que o lugar defronta o mundo, mas também o confronta, graças à sua própria ordem. Esses destaques de Milton Santos reforçam o pensamento de que uma das grandes contradições do mundo contemporâneo é aquela que opõe, de um lado, o acelerado desenvolvimento técnico e, de outro, o aprofundamento das desigualdades socioeconômicas e territoriais. Esse e outros processos fazem parte da lógica de acumulação capitalista que, a um só tempo, cria a abundância e a escassez, divide e especializa o trabalho na 
unidade de produção, na sociedade e no território com base no desenvolvimento geograficamente desigual e combinado.

Massey ${ }^{6}$ (1993) analisa a ideia de compressão espaço-tempo no âmbito da globalização, acrescentando suas distintas "geometrias do poder", em que a compressão se multiplica pela desigualdade de suas configurações, de sua origem e de sua distribuição. Assim, torna-se imprescindível distinguir quais são seus agentes e como a globalização afeta diferentemente não só as classes sociais, em termos das violentas desigualdades sociais em que todos se inserem, mas também as diferentes etnias, os diferentes gêneros, grupos etários, etc. A compressão espaço-tempo, nesse contexto, portanto, não diz respeito apenas a quem se desloca e a quem não se desloca; diz respeito também ao poder em relação aos fluxos e ao movimento. Diferentes grupos sociais têm distintas relações com essa mobilidade igualmente diferenciada. Alguns são mais implicados do que outros; alguns iniciam fluxos e movimentos, outros não; alguns estão mais na extremidade receptora do que outros; alguns estão efetivamente aprisionados por ela (MASSEY, 1993, p. 61). Não se trata, porém, de uma transformação meramente quantitativa, como mais alternativas territoriais, maior facilidade de acesso, maior velocidade de mudança. Para Haersbaert (2005), há uma transformação qualitativa, envolvendo tudo, que se revela como sendo a nova experiência de tempo-espaço, mais fluida, e que inclui a compressão ou o desencaixe espaço-temporal - mergulhados nas distintas "geometrias de poder", profundamente diferenciadas de acordo com as classes sociais e os grupos culturais.

Além do reconhecimento da complexidade da compressão tempo-espaço a partir da diferenciação dos seus objetos e atores, e das relações de poder extremamente desiguais, como destaca Massey, é importante focalizar outra questão tão ou mais relevante: o reconhecimento de que a compressão espaço-tempo envolve apenas uma das formas com que o espaço social se manifesta, aquela que se encontra mais diretamente ligada ao que Shields (1992) denomina relação de "presença e ausência". Juntamente com a diferenciação ou contraste, a inclusão e a exclusão ou o dentro e o fora, a relação de presença e ausência integra o conjunto dos três componentes 
da espacialização da sociedade, segundo o autor: "inclusão, exclusão e diferenciação espacial continuam aparentemente imutáveis. Pode-se afirmar que as desigualdades e a exclusão sócio-espacial foram até intensificadas" (SHIELDS: 1992, p.187). Para Shields, o pós-modernismo, fenômeno contemporâneo da globalização, desestabiliza a estrutura metonímica que relaciona presença e ausência com proximidade e distância.

\footnotetext{
Uma união sintética de distância e presença, do estrangeiro e do íntimo, torna-se concebível e praticável [...] As próprias fronteiras, assim, mudariam de sentido, elas podem ter-se tornado mais do que linhas que definem o que está delimitado do que não está, o ordenado do não-ordenado, ou o conhecido do desconhecido, mas, tais fronteiras parecem estar se dissolvendo.
}

(SHIELDS, 1992, p.192)

Segundo Shields, o resultado dessa relação complexa entre presença e ausência é um espaço profundamente descontínuo, fragmentado. Pode-se destacar o movimento, ação ou processo global como a possibilidade de acessar ou conectar, num mesmo local e ao mesmo tempo, diversos territórios. Isso pode se dar tanto por uma "mobilidade concreta", no sentido de um deslocamento físico, quanto informacional, no sentido de acionar diferentes territorialidades, mesmo sem deslocamento físico, como em algumas experiências proporcionadas por meio do chamado ciberespaço. Alguns objetos se movem muito mais rapidamente do que outros, afetando a vida de todos que dependem dessa mobilidade. Enquanto alguns produtos efetivamente se libertam do constrangimento da distância, outros adquirem novos valores justamente por dependerem dessas distâncias e por se tornarem, assim, relativamente menos acessíveis. Portanto, a seletividade espacial é resultado da forma como as redes de tecnologia se organizam. O tempo necessário para cruzar distâncias pode ter diminuído de maneira inversamente proporcional aos diferentes modos de fazê-lo, mas o acesso a esse privilégio é tão mais restrito quanto maior for a sua potencialidade técnica e seu alcance espacial. Nessa perspectiva, os territórios são mais densos e mais complexos se considerados sob o ângulo dos múltiplos poderes que nele e sobre ele atuam.

A globalização, portanto, não é apenas resultado dos avanços tecnológicos e dos mercados competitivos em expansão, mas fundamentalmente um 
fenômeno político e ideológico. Tomar consciência do processo nos leva a refletir com profundidade sobre as dimensões conflitantes e contraditórias da realidade brasileira, em especial, dos lugares alvo das redes técnicas. Pensar em ordenar o território na atual conjuntura requer, como pressuposto, diversificar o foco e as escalas de análise, identificar a forma como os vetores econômicos se distribuem nos infindáveis circuitos espaciais, entender essa complexidade como associada à mudança da base técnica produtiva do país, destacando as forças motrizes que têm impulsionado a especialização/diferenciação dos lugares. É preciso ir além do espaço físico, sem entretanto, subestimá-lo; é preciso pensar em diferentes escalas, integrando a lógica da continuidade e da descontinuidade no espaço. Com isso, é preciso repensar as regiões, ressaltar os novos eixos e a nova logística territorial nacional, condição técnica e operacional indispensável para se pensar o planejamento e/ou políticas públicas.

A forma de inserção regional/local no processo de globalização transforma as condições históricas do território, engendrando novas formas de produção do espaço ordenador/ regulador. Para tanto, é necessário resgatar conceitos sistematizados pela geografia que possam auxiliar na compreensão da inserção econômica do estado do Espírito Santo nas redes globais e como se dão as manifestações locais para esta nova realidade.

\subsection{As fronteiras não impõem limites às redes técnic as}

Com a globalização, as ações e estratégias do planejamento, em geral, se fundam nas tecnologias de rede e, em última instância, têm seu rebatimento no território, o que não determina que este seja pensado apenas como mero palco das ações políticas, mas como uma representação em si mesmo. O resgate das origens do conceito do território é essencial para esclarecer sua condição atual. Cada autor, dependendo da sua linha de trabalho e de suas concepções teórico-metodológicas, dá ênfase a alguns aspectos dentro do território, seja o aspecto econômico, político e cultural ou o entrelaçamento desses fatores, para explicar o conceito e a dinâmica de um espaço que está sempre em construção. Não é objetivo, aqui, proceder a uma extensa revisão bibliográfica sobre conceitos de território; porém alguns pressupostos básicos acerca do território estabelecidos pela Geografia clássica e crítica, são necessários para introduzir a questão. Se, 
por um lado, há proposições que distinguem o território como área de exercício do poder e da soberania do Estado, concepção associada às raízes da Geografia política, por outro lado, o território pode ser entendido como espaço identitário. Soma-se a esses dois conceitos, outra proposição contemporânea que afirma ser o território a própria expressão do movimento global.

O conceito fundador do território para a Geografia encontra-se em Paul Vidal de La Blache, que convencionou usar expressões como "fisionomia de uma região", "fisionomia de um país", "fisionomia da paisagem" ou "fisionomia da terra". Trata-se de levar em conta, toda vez, a característica do território considerado, isto é, aquilo que o especifica e o distingue dentre os outros, e que é preciso compreender. "Fisionomia e característica não são representações subjetivas, são realidades objetivas que identificam verdadeiramente um território, e que é necessário reconhecer, delimitar, localizar, tanto espacialmente como qualitativamente, a fim de reproduzilas", como observa La Blache, que prossegue afirmando que é, "portanto, sobre o plano das aparências que é preciso se situar para apreender toda a sua densidade epistemológica e ontológica. $\mathrm{O}$ aspecto das coisas é uma realidade geográfica."7

O território, suporte da ação dos homens em um processo contínuo e ininterrupto, associa as referências naturais expressivas às culturais historicamente construídas, numa relação ímpar de identificação do território. As heranças vão se acumulando no tempo e no espaço por meio de sua materialidade historicamente socializada. Pertencer a um determinado lugar faz parte de um processo de identificação com seu entorno. O lugar passa a ter significado simbólico. E, nesse contexto, ressalta-se o trabalho mútuo e de cooperação entre os homens, como fator de evolução, como marca da luta pela existência. Falar em território é evidenciar que os lugares nos quais estão inscritas as existências humanas foram construídos pelos homens, e, ao mesmo tempo, pela sua ação técnica e pelo discurso que mantinham sobre a ação. As diversas etapas do processo de trabalho determinadas pelas relações sociais, marcam, também, as mudanças verificadas no espaço geográfico, tanto morfologicamente, quanto do ponto

7 Texto: A fisionomia da paisagem, de Alexander Von Humboldt a Paul Vidal de La Blache. Tradução Vladimir Bartalini (AUP5834). FAU / USP. Pg.44 
de vista das funções e dos processos. É assim que as épocas se distinguem uma das outras.

Há de se considerar que, dependendo do grupo cultural, do contexto histórico e geográfico, o processo de territorialização se dá privilegiando determinadas variáveis que se conjugam no tempo e no espaço. Tanto as representações territoriais quanto as identidades intrínsecas a elas são categorias e produtos da cultura, em um determinado momento, num certo ambiente. O território é, pois, sempre conjuntura histórica e forma geográfica que incorpora sentido por meio dos processos sociais que se expressam por meio dele. Muitas dessas formas vão se acumulando de maneira diferenciada ao longo do tempo, originando a multiplicidade de regiões hoje existentes com características diversas conjugadas num território mais amplo, o país.

Como não poderia deixar de ser, Milton Santos dá relevantes contribuições para a construção do conceito de território em várias de suas obras, de grande importância para a Geografia. Para Santos (1979), um espaço nacional pode ser estudado como um sistema, cujos recursos são, na verdade, indivisíveis do capital, da população, da força de trabalho, etc. O autor entende que não há como pensar o espaço desvinculado do território: "a configuração territorial se compõe do conjunto de sistemas naturais e dos acréscimos superpostos pela socie $\neg$ dade em uma área ou país" (SANTOS, 1996, p. 51). E o autor prossegue na sua argumentação: “em cada período histórico esses recursos se combinam e se distribuem de maneira diferente". Santos provoca o leitor, movendo-o para seu raciocínio amplo e significativo da importância maior em compreender a categoria território, uma vez que, para o autor, é na base territorial que tudo acontece, mesmo com as configurações e reconfigurações mundiais influenciando o espaço territorial.

Raffestin (1993, p.150-151) reconhece a relação intrínseca entre território e modos de vida, ao afirmar que "a prática espacial se traduz por uma produção territorial, por mais simples que seja a sociedade, gerando sistemas de malhas, nós e redes que se imprimem no espaço, constituindo o território”. A análise de Raffestin enfatiza a construção do território mediante relações marcadas pelo poder. $\mathrm{Na}$ concepção do referido autor, o territó- 
rio é tratado, principalmente, com uma ênfase político-administrativa, isto é, como o território nacional, espaço físico onde se localiza uma nação; um espaço onde se delimita uma ordem jurídica e política; um espaço medido e marcado pela projeção do trabalho humano com suas linhas, limites e fronteiras. Assim, para o autor, faz-se necessário focar a análise em uma categoria essencial para a compreensão do território, que é o poder exercido por pessoas ou grupos sem o qual não se define o território. Poder e território, apesar da autonomia de cada um, vão ser enfocados conjuntamente para a consolidação do conceito de território. Observa-se, então, porque os problemas do território e a questão da identidade estão indissociavelmente ligados. Assim, o poder é relacional, pois está intrínseco em todas as relações sociais, conforme observa Raffestin:

[...] um espaço onde se projetou um trabalho, seja energia e
informação, e que, por conseqüência, revela relações mar-
cadas pelo poder. (...) o território se apóia no espaço, mas
não é o espaço. É uma produção a partir do espaço. Ora,
a produção, por causa de todas as relações que envolve, se
inscreve num campo de poder [...]

(RAFFESTIN, 1993, p. 144).

Haesbaert analisa o território com diferentes enfoques, elaborando uma classificação em que se verificam três vertentes básicas: 1) jurídico-política, segundo a qual "o território é visto como um espaço delimitado e controlado sobre o qual se exerce um determinado poder, especialmente o de caráter estatal"; 2) cultural(ista), que "prioriza dimensões simbólicas e mais subjetivas, ou seja, o território visto fundamentalmente como produto da apropriação feita através do imaginário e/ou identidade social sobre o espaço": 3) econômica, "que destaca a desterritorialização em sua perspectiva material, como produto espacial do embate entre classes sociais e da relação capital-trabalho" (HAESBAERT apud SPOSITO, 2004, p.18).

Com base nas argumentações dos grandes autores da Geografia, poderíamos afirmar que a relação tecida entre a história e o espaço fornece uma base aparentemente material à identidade que se configura em um território. O território é, assim, domínio (natural, concreto) e apropriação (simbólica), sendo ambos formas de controlar e ordenar; porém, a existência e influência das redes globais e fluxos é considerada como ele- 
mento essencial para complementação do conceito do território. Pensar a condução de políticas de ordenamento territorial não pode prescindir desse entendimento. Nessa perspectiva, ao se definirem os limites dos territórios dotados de certa homogeneidade natural, cultural e simbólica, há que se considerar a preponderância dos múltiplos fluxos e conexões que atravessam esses territórios e que fazem de cada um deles a combinação específica de um conjunto de redes. De certa forma, a complexidade do contexto mundial é ressaltada como uma dificuldade para implementar o ordenamento do território, com base no pressuposto de que as redes de informação, empresariais e sociopolíticas, transcendem fronteiras e geram novas relações locais/globais.

A nova dinâmica imposta pela globalização implica reconhecer que as novas redes de fluxos funcionam mediante circuitos conectados externamente $\mathrm{e}$, no mais das vezes, por cima ou à margem dos sistemas de regulação e controle de que dispõem os governos nacionais e estaduais. Diante dos novos desafios que o fenômeno da globalização propõe, muitos autores identificam a evidente instabilidade da configuração territorial clássica adotada pela Geografia. O espaço global se reorganiza para atender as novas necessidades do processo produtivo, que não mais reconhece, necessariamente, as fronteiras regionais, territoriais ou culturais. Podemos nos reportar a essas dinâmicas de fluxos em constante movimento, que interagem no espaço, como as denominadas por Deleuze e Guattari (1980) de "desterritorialização" e que, por isso, devem ser consideradas em qualquer processo de operacionalização de políticas de planejamento territorial que procurem um resultado mais eficiente.

Essa nova articulação territorial em rede dá origem a territórios-rede flexíveis, onde o mais importante é ter acesso aos pontos de conexão que permitem jogar com a multiplicidade de territórios existentes, criando assim uma nova territorialidade. Não se trata, também, como no passado, da simples possibilidade de acessar diferentes territórios. Trata-se, de fato, de vivenciá-los, concomitante e/ou consecutivamente, num mesmo conjunto, sendo possível criar aí um novo tipo de experiência espacial integrada. Essa multiplicidade de justaposição ou convivência simultânea de tipos territoriais distintos será denominada por Haesbaert como "múltiplos territórios". Ele sintetiza esse fenômeno pela ocorrência das seguin- 
tes modalidades: uma dimensão tecnológica de crescente complexidade que resulta na extrema densificação de alguns pontos do espaço altamente estratégicos; uma dimensão simbólica cada vez mais importante, onde é impossível estabelecer limites entre as dimensões material e imaterial da territorialização; o fenômeno do alcance planetário instantâneo (dito em "tempo real"), por contatos globais dotados de alto grau de instabilidade e imprevisibilidade; a identificação espacial ocorrendo muitas vezes no/ com o próprio movimento e, no seu extremo, com a própria escala planetária (HAESBAERT, 2002, p.47-48).

A cada novo período, especialmente com o fenômeno da globalização, as fronteiras constituídas historicamente estão sujeitas às novas ações e comandos de agentes hegemônicos que se estabelecem no plano mundial. Em seu estudo sobre territorialidade e identidade, Claval (1996) considera que, assim como todas as construções, as identidades também podem ser colocadas em questão - e por vezes o são. Há crises identitárias que provocam frequentemente uma modificação da relação com o espaço: as transformações da realidade espacial correm o risco de provocar, ao contrário, um questionamento das construções identitárias; elas devem ser reformuladas ou reconstruídas sobre novas bases. Considerando essa linha argumentativa, o espaço territorial está sujeito a transformações sucessivas, conforme seja analisado sistematicamente no contexto histórico. A partir dos sistemas de variáveis e a ocorrência de fenômenos que conjugam cada período histórico, há possibilidade de desmantelamento da ordem estabelecida e a harmonia do conjunto anterior. As cidades se transformam em polos de um sistema articulado em escala mais ampla, regional, mundial, no qual se desenvolvem novas bases operacionais.

O quadro que se apresenta na contemporaneidade, portanto, é o da reorganização da vida cotidiana. A construção e a destruição de regiões são indissociáveis da construção, da destruição e da reconstrução de territórios. O problema, então, é o de como regionalizar ou polarizar atividades em torno de uma região, num mundo envolvido em dinâmicas sempre mutantes. Conforme sejam dadas as rupturas e descontinuidades históricas, surgem rearranjos organizacionais que se privilegiam das técnicas como forma de constituir um novo sistema inteligente para superação das adversidades. Poderíamos, assim, reconhecer diversos momentos em um 
processo de evolução que é permanente.

Em outros termos, está-se diante de um movimento de diferenciação de espaços territoriais de largo espectro, e os vetores que o impulsionam são de natureza multidirecional e, em grande medida, estão relacionados aos usos divergentes, competitivos e conflitantes dos lugares e das suas potencialidades intrínsecas (recursos naturais, posição na rede de fluxos, infraestrutura e outras), bem como às migrações dos capitais produtivos (principalmente os industriais) nas escalas intrametropolitanas, intermunicipais, interestaduais e inter-regionais. Observa-se que, no Brasil, prevalecem as desigualdades socioespaciais e em escalas diversas, isto é, nas regiões, nos estados, nas metrópoles e nos centros urbanos. As interconexões das diversas escalas do espaço variam de acordo com sua capacidade de acumulação técnica, o que é, para Milton Santos, revelador da produção histórica da sociedade e do acúmulo da riqueza na sociedade capitalista.

Desse modo, os conflitos reais e potenciais embutidos no complexo e desigual uso do território se revelam de forma explícita na materialidade concreta, cabendo ao poder público, seja qual for a instância de poder que esteja legitimada, a função de ordenar e gerir esses espaços territoriais. Pela perspectiva dessa reflexão, uma das consequências da globalização é a forte tendência atual de restringir/confinar a formulação das políticas públicas abrangentes (ou estratégicas) às regiões ou porções do território nacional nas quais se verificam as menores densidades de fluxos e redes. Pensar o "planejar" implica estabelecer conexões entre focos dinâmicos da economia e das regiões e lugares postos à margem desse processo de reconfiguração acelerada do território nacional. Nesse contexto, o planejamento teria por princípio estabelecer um diagnóstico que permita identificar e representar os principais movimentos e vetores que impactam as regiões e os lugares, indicando tendências e aferindo demandas e potencialidades de modo a estabelecer metas para as políticas públicas.

\subsection{0 temitónio: estruturação na escala local, regional e nacional}

O Brasil está inserido num processo globalizante, onde os territórios, assim como as regiões, estão se tornando muito mais complexos, imersos em redes múltiplas de relações locais/globais, cujas variáveis os atingem e 
os transformam de forma acelerada. Como vimos, esse movimento dinâmico e global acirra as múltiplas diferenciações econômicas e regionais. $\mathrm{O}$ país como um todo é emblemático dessa situação desigual, o que sugere pensar a forma como se instalam as redes globais no território nacional: a riqueza se dá, mas, simultaneamente, a reboque da marginalização social de grande parte da nação. Assim, qualquer proposta de mudança ou ordenamento do território que possa reverter este quadro em benefício de toda a sociedade passa, necessariamente, por uma tentativa de compreender o território como uma totalidade, a partir das ações e dos usos de todos os atores que nele operam. A compreensão do planejamento das ações pressupõe a verificação dos fatos e as peculiaridades da organização territorial brasileira numa escala mais ampla, global, passando pela escala local, regional e nacional.

Para referenciar as análises, é importante nos reportarmo-nos aqui às diferentes escalas que designam as diversas intervenções no espaço. A abordagem antes de tudo deve ser relacional, conforme propôs Lacoste (1976), considerando-se, em primeiro plano, a forma e a natureza das relações sociais e suas interações espaciais, cuja percepção poderá variar bastante, de acordo com o contexto; por exemplo, regiões em Portugal e certas regiões no Brasil dizem respeito a recortes em dimensões muitíssimo diferentes. Em geral, o recorte territorial local é identificado, muitas vezes e simplesmente, com os limites jurídico-administrativos, restringindo-se, preferencialmente, ao município. Entretanto, na escala "local", há que prevalecer a ideia de recortes espaciais em graus variáveis, de acordo com o seu tamanho, expressando esses recorte a vivência pessoal do espaço. Santos define a "cidade local como a aglomeração capaz de responder às necessidades mínimas vitais, reais ou criadas, de toda uma população, função esta que implica uma vida de relações”(SANTOS, 1979, p.71). Já a escala regional, bastante debatida por geógrafos, variáveis distintas lhe podem ser atribuídas, mas em primeiro lugar o fato de ela constituir uma identidade imediata do nível local, onde ocorrem processos e peculiaridades similares. Uma característica da escala regional é que ela pode se desdobrar em vários níveis, podendo chegar a até três: macrorregional, (meso) regional e microrregional. A escala nacional diz respeito à escala do país, do território ocupado por um Estado soberano. E, por fim, a escala global abrange o mundo inteiro e diz respeito, sobretudo, a fenômenos de ordem 
econômica no sistema mundial capitalista (SOUZA, 2006, p104-110).

Há que se considerar a diferenciação regional como pressuposto básico para entendimento da configuração e estruturação do território brasileiro, que vai se dar muito em função do caráter histórico de uso do território apropriado pelo Estado para consecução de seus objetivos. Na hipótese de Lefebvre, o espaço desempenha uma função na estruturação de uma totalidade, como um instrumento político, à medida que é apropriado, transformado em território. A representação do território está, assim, sempre a serviço de uma estratégia projetada. O Estado, a sociedade e a estrutura territorial compõem a totalidade, com múltiplos centros federados de poder, múltiplos núcleos de atores públicos e privados e uma estrutura territorial que se torna, progressivamente, mais densa, à medida que reflete a multiplicidade de poderes específicos e seus projetos de desenvolvimento sobre territórios determinados (LEFEBVRE, 1976, p.25-31).

Para se pensar a questão regional no âmbito do planejamento, vale aqui resgatar o conceito de região, diretamente vinculado ao de território. Território e região são como dois conceitos-chave da Geografia; precisam andar juntos e são mesmo indissociáveis. Não há consenso para o estabelecimento de uma definição única do conceito de região, o que, muitas vezes, torna necessário considerar, para efeitos referenciais, a região como uma construção de espaços territorialmente delimitados, para algum objetivo específico. O que subsiste é a necessidade de tratá-la não somente como um objeto rígido, mas como fenômeno que se transforma historicamente. Para Komar (1976), "uma região é uma área que tem uma categoria histórica. No curso da evolução social, muda com relação aos seus conteúdos e quanto ao grau de diferenciação interna, podendo também alterar-se territorialmente em uma ou outra medida" (KOMAR Apud LEITE:2006, p.25).

Um dos referenciais teórico-metodológicos em que se apoia a questão regional é aquele que procura conciliar elementos de homogeneidade e heterogeneidade desenvolvidos sistematicamente desde o século XIX. O primeiro caminho procura envolver aspectos e indicadores geográficos, sociais, econômicos e culturais que permitam compor uma determinada área com características comuns de forma a tratá-la como região homogê- 
nea. O segundo caminho busca ressaltar a natureza heterogênea do espaço ou território produzida na existência local de um estoque (infraestrutura, recursos humanos, capital, etc) e de fluxo (migração, informação, conhecimento, mercadorias, serviços). Conciliar essas duas premissas básicas permite levar em conta a importância, não da análise estática da região, mas de contextos dinâmicos, de fluxos que interagem intra e entre lugares ou áreas. Ademais, um dos princípios do desenvolvimento é a valorização das diferenças - base da competitividade e da complementaridade -, reconhecendo-se não haver um modelo único a ser adotado, mas, sim, múltiplos caminhos a configurar o desenvolvimento como um processo de mudança, e não como um estado em si.

Algumas teorias acerca da organização espacial exerceram considerável influência na adoção de planos setoriais de intervenção no Brasil, particularmente as da escola francesa ${ }^{8}$. Essas teorias viam o Estado como o sujeito motor da intervenção e da ação, sendo o território um conjunto a ser dividido em regiões de desenvolvimento, sujeitas a processos de hierarquização, estruturação e polarização. A ideia força central ${ }^{9}$ dessas teorias, mais implícita que explícita, continuava a ser a da modernização da cidade.

Em um texto clássico da geografia regional, Kayser ${ }^{10}$ (1969) escreveu o seguinte: "o espaço polarizado que se organiza em torno de uma cidade é uma região". No artigo, o geógrafo destacou a força centrípeta exercida pela cidade, que ocorreu em função da progressiva concentração espacial de bens e serviços e dos meios de produção que interferem na dinâmica econômica regional. Essa linha de raciocínio não é nova e foi motivada, em grande parte, pelo reconhecimento de processos socioeconômicos que romperam os limites jurídico-administrativos do que convencionalmente chamamos de cidade. No Brasil, essas teorias vinculadas a polos de desen-

8 Dentre as principais teorias formuladas, destacam-se a "Teoria do Lugar Central”( 1930/1940), representada pelo geógrafo Walter Christaller, e a "Teoria dos Pólos de Desenvolvimento", representada principalmente por Perroux. A primeira considera o espaço plano e homogêneo, no qual a cidade é considerada como um lugar central. A segunda, baseia-se no princípio da heterogeneidade a partir de polos de desenvolvimento. A atração exercida pela cidade em torno de sua área circundante, em razão das atividades comerciais e de serviços, provoca a criação de áreas de influência, formando as regiões polarizadas. (CROCCO, M. CEDEPLAR/UFMG.2008)

9 A ideia- força central tem origem no Urbanismo modernista de Le Corbusier, complementada por outras ideias-força como ordem e racionalidade, assim como modernização da cidade.

10 KAYSER, B. (1969). A região como objeto de estudo da geografia. In: GEORGE, Pierre et alli. A geografia ativa. São Paulo:Difel, 1980, p.283 
volvimento se adequaram ao momento de autoritarismo político, servindo assim de apoio ideológico à formulação de políticas espaciais que tinham por discurso a correção dos desequilíbrios regionais. Entretanto, o enfoque racional, esteve, via de regra, ligado a uma realidade estruturada em sistemas, o que não contemplava as prioridades ou os problemas concretos a serem superados, mas, sim, girava em torno dos procedimentos, vale dizer, do método.

\begin{abstract}
A abordagem sistêmica (systems planning), e mais ainda uma variante a ela estreitamente racional (racional process view) sublinharão a racionalidade dessa abordagem como elemento distintivo em face do planejamento físico-territorial. Não que a preocupação com a racionalidade estivesse ausente do planejamento clássico; entretanto, a maneira como essa preocupação passa a ser veiculada conhece uma virada nos anos 70. Em ambos os casos, trata-se de uma racionalidade instrumental, que se volta exclusivamente para a adequação dos meios a fins preestabelecidos, permanecendo estes últimos inquestionáveis.
\end{abstract}

(SOUZA, 2006, p.132)

As ações implementadas pelo planejamento desde o início da formação do meio-técnico-científico no Brasil, assim como no caso do Espírito Santo, criaram antagonismos socioambientais e desigualdades regionais, priorizando sempre, e, em primeira instância os interesses dominantes. As desigualdades regionais são flagrantes e pronunciadas. O sistema de infraestruturas e de redes técnicas desigualmente distribuídas concentra-se nas regiões Sudeste e Sul, conforme atestam Santos e Silveira (2005). Essa concentração se dá devido a um processo circular, no qual a divisão territorial do trabalho mais intensa gera uma maior necessidade de circulação e encontra resposta na difusão dos transportes, que permite, por sua vez, uma maior especialização e distribuição das funções produtivas.

O planejamento público nacional centralizado dos anos 1980 foi a alternativa encontrada para minorar as disparidades regionais; entretanto, trouxe em seu bojo a falência do planejamento regional pautado numa visão fundamentalmente macrorregional (regiões administrativas). A implementação das ações de liberalização da economia e de redução do papel do Estado não favoreceram o planejamento público, em particular o regional. Ao contrário, observou-se uma não adequação de ferramentas ao novo 
contexto mundial e o desmantelamento dos vários instrumentos disponíveis até então.

Alguns fatores concorreram decisivamente para enfraquecer a legitimidade do exercício de planejar. Na tradição político-administrativa brasileira, a região sempre foi mais uma escala de intervenção do que de administração. Assim, as regiões responderam muito mais à centralização do que à descentralização, ao contrário do que ocorreu, por exemplo, na França. O resultado disso é que, exceção feita para raros casos, a forma como o planejamento se instaurou no Brasil não foi capaz de estimular um "pensar" para além do reconhecimento da polarização regional. Outro fator relevante foi a derrota do planejamento no âmbito urbano com a transferência das responsabilidades para os planos diretores e o esvaziamento dos movimentos sociais urbanos que haviam dado suporte ao Movimento Nacional pela Reforma Urbana ${ }^{11}$. A importância de planos e garantias formais foi exagerada, em detrimento de uma análise social mais ampla. A participação popular, que, deveria ser vista como o fator-chave para a democratização do planejamento, tornou-se secundária, haja vista a pouquíssima atenção dispensada aos conselhos municipais e de desenvolvimento.

Nos anos 2000, os avanços na agenda de curto prazo do país permitiram cogitar a reestruturação do planejamento de médio e longo prazo. O ideário político-econômico liberal passa a fornecer as grandes linhas inspiradoras de ações que visam às reestruturações econômicas e territoriais. Nesse novo contexto, a questão regional vem retomando seu papel de relevância, perdida nas últimas décadas. Hoje, devido ao impacto dos movimentos preponderantes das redes globais sobre as nações, reconhece-se que as unidades territoriais, seja regiões seja municípios, permanecem como importantes atores no cenário mundial, e procura-se fortalecer as possibilidades de eixos de desenvolvimento. Com o indiscutível fortalecimento dos municípios nos últimos quinze anos, decresce consideravelmente o poder da União como indutor e o coordenador exclusivo das estratégias e políticas de alcance nacional. Desse modo, reforça-se a necessidade do Estado em compreender e agir sobre as regiões, em especial, as metropolitanas e

11 No Brasil, no final da década de 1980, surge a concepção progressista da Reforma Urbana, caracterizada como um conjunto articulado de políticas públicas, de caráter redistributivo. A Reforma Urbana estaria voltada para o atendimento do seguinte objetivo: reduzir os níveis de injustiça social no meio urbano e promover uma maior democratização do planejamento e da gestão das cidades. 
os aglomerados urbanos, que são, atualmente, os mais importantes vetores de especialização e de diferenciação do território nacional. Esses espaços territoriais (metropolitanos) representam forças de difícil controle e coordenação, seja pela complexidade inerente a eles, seja pela sobreposição das escalas de gestão dos níveis de governo que neles atuam. Nesse contexto, uma questão suscita conflitos de competência no seio do Estado ante a existência das territorialidades-redes: como ordenar e o que ordenar?

Pensar em política pública de ordenamento territorial ou de mitigação dos problemas expressos no território implica pensar uma dimensão tecnológica de crescente complexidade, que resulta na densificação de alguns pontos altamente estratégicos do espaço. A importância do quadro atual é destacada por meio da construção de novas formas no exercício das funções do Estado e dos diversos atores intervenientes. De certa forma, há uma postura inovadora na condução de políticas públicas no Brasil quando se atribui papel central ao território na consecução de objetivos estratégicos. Uma premissa a realçar é a da revalorização das regiões no contexto mundial, não mais tratadas somente como provedoras passivas de insumos ao desenvolvimento.

Com a mundialização dos mercados e o processo de globalização econômica e cultural, a importância das regiões e dos blocos regionais ganhou novos contornos, constituindo-se em doutrina a defesa das economias regionais e a possibilidade de competitividade dessas economias na economia global. As escolhas são feitas também pela eficiência das malhas de coordenação e pelo alcance da gestão de recortes territoriais mais reduzidos. Nessa perspectiva, o fortalecimento da rede de cidades e/ou microrregiões favorece a criação de novas centralidades, motivada por interesses econômicos. As cidades deixam de ser apenas as sedes da vida cotidiana, para se transformarem em polos de um sistema articulado em escala mais ampla, a regional, favorecidos pela mobilidade e flexibilização do sistema de transportes e comunicação. As grandes cidades continuam a exercer importância na articulação e polarização econômica, em especial, as metrópoles.

A possibilidade de antecipar os efeitos locais de uma determinada ação, tendo o território como referência prévia, é que faz a região uma ferra- 
menta estratégica importante. O planejamento das ações deve ter por princípio as regiões consideradas como estruturas socioespaciais ativas, possuindo, conforme sejam ordenadas, a capacidade de ajustar-se à dinâmica da competição global. Hoje, as abordagens do território no contexto do planejamento conciliam a importância de contextos dinâmicos, de fluxos que interagem intra e entre locais. Em linhas gerais, a análise da literatura aponta que os arranjos territoriais, que, de alguma forma, são adjetivados de "cidades-regiões"12, são resultados do período de acumulação flexível, das transformações do sistema fordista e das novas tecnologias que se transformaram em fator de produção. A esse respeito, Harvey escreve:

\footnotetext{
A acumulação flexível envolve rápidas mudanças dos padrões de desenvolvimento desigual, tanto entre setores quanto em regiões geográficas, criando, por exemplo, um vasto movimento no emprego chamado "setor de serviços", bem como conjuntos industriais completamente novos em regiões até então subdesenvolvidas tais como "Terceira Itália”, Flandes, os vários vales e gargantas do silício, para não falar da vasta profusão de atividades dos países recém-industrializados. (HARVEY, 2000, p.140)
}

Essa linha de raciocínio em torno das cidades que influenciam uma abrangência maior de escala não é nova e foi motivada, em grande parte, pelo reconhecimento de processos socioeconômicos que romperam os limites jurídico-administrativos do que convencionalmente chamamos de cidade. Tanto na análise da literatura quanto no debate sobre as políticas governamentais, os argumentos sobre as cidades-regiões prevalecem em dois pontos principais: 1) a abertura ao mercado global fez com que as estruturas locais e regionais se tornassem mais frágeis, o que, em alguns casos, coincide com mudanças na base produtiva, com impacto direto na oferta de emprego; 2) de posse desse diagnóstico e com base na ideia de reestruturação, caberá aos atores locais-regionais (o regional é uma forma de dizer que os problemas da reestruturação atingem mais que uma cidade) reunir forças para superar os problemas (ARRAIS, 2008, p.86).

O avanço teórico-empírico recente no campo do planejamento regional é

$12 \mathrm{O}$ conceito de cidade-região se aplica às regiões metropolitanas ou cidades que exercem grande influência sobre outras em seu entorno, preferencialmente no que diz respeito às atividades econômicas e de prestação de serviços. 
respaldado por novos e sofisticados instrumentos metodológicos, em face dos resultados positivos alcançados na União Europeia. A nova política industrial francesa, por exemplo, tem no seu eixo principal, os chamados "polos de competitividade". Esses pólos são constituídos de projetos coletivos que reúnem empresas (com uma, pelo menos, considerada âncora), centros de pesquisa, em uma zona geográfica determinada. Trata-se de um instrumento de competitividade industrial/empresarial e de atratividade territorial/empresarial, que tem como critérios a inserção territorial, a visibilidade internacional, a qualidade das parcerias e sinergias potenciais entre empresariado e desenvolvimento do território ${ }^{13}$. Esses polos urbanos direcionais, as chamadas cidades mundiais ou cidades-regiões globais, com suas complexas redes de empresas, são lugares estratégicos para a produção de funções especializadas. As cidades deslocam crescentemente sua atenção dos assuntos internos para atividades externas, ganhando consciência da importância, para seu desempenho, de decisões tomadas fora de suas fronteiras. Mas a questão que permeia a reflexão não passa apenas pelo reconhecimento da existência de processos econômicos que integram cidades e regiões. Agnew coloca a questão da seguinte forma:

A questão é que essas regiões raramente coincidem com as regiões político-institucionais. Portanto, há um déficit político na capacidade das cidades-regiões administrarem seus negócios. O Estado ainda controla a maior parte das alavancas das políticas e planos de ação.

(AGNEW, 2000, p.106)

Considerando o argumento de Agnew, nos países em desenvolvimento em especial, o foco do debate sobre as "cidades-regiões" passa a ser, desse modo, político, e isso serve para diferentes formações regionais, especialmente porque o prevalecimento da questão econômica tornou mais visíveis os problemas de degradação ambiental, falta de saneamento básico, desemprego, carência de infraestrutura urbana. De modo geral, as alianças estratégicas do planejamento atual são condicionadas pelo viés dos interesses empresariais na definição da agenda, o que muito pouco resta em matéria de discurso sobre o interesse público. Reside, portanto, no fato político, a necessidade de reconhecer/estimular respostas para além da

13 BRASIL. Ministério da Integração Nacional. Anais da I Mostra Nacional de Desenvolvimento Regional. Salvador. 2009. 
escala local.

No entender de Santos, o comando do funcionamento do meio técnico há muito deixou de estar nas mãos dos Estados nacionais e, hoje, está concentrado nas grandes empresas multinacionais, que se organizam em forma de oligopólio, cuja coordenação de decisões, graças à sua flexibilidade, constitui um poderoso instrumento de expansão econômica (SANTOS, 2005, p.305). É preciso qualificar os atores ${ }^{14}$, explicitando seus interesses na questão regional de modo a desvendar o significado de sua ação, pois disso depende a percepção do que foi, do que é e do que será uma determinada região.

$\mathrm{Na}$ verdade, há uma dificuldade em visualizar tanto os desafios quanto os atores. A questão colocada é eminentemente política, o que depende, fundamentalmente, de considerar a tradição das políticas territoriais e até mesmo a questão federativa dos diversos países, e não apenas o contexto de inserção na globalização. Apesar de o país estar em processo de democratização, ainda não se observa, seja tecnicamente, seja politicamente, um referencial convergente para a constituição de estratégias de implementação de instrumentos dos agentes públicos ou privados na questão do ordenamento territorial. No Brasil, a questão regional é uma questão setorial, tratada em suas várias especificidades. A falta de uma visão e de um arcabouço mais consistentes sobre a questão propicia que cada parcela de poder público (União, estados e municípios), a despeito de objetivos setoriais legítimos, elabore e pratique sua própria visão de organização do território e das ações territoriais. Essa situação de compartimentalização das políticas fica evidente na diversidade de propostas de regionalização existentes no país. Cada órgão do governo ou do Estado, ou mesmo do setor privado, tem sua atuação, de alguma forma, territorializada.

Por mais embasadas numa análise da realidade que sejam as propostas de intervenção, para serem inteiramente legítimas, elas necessitam ser submetidas à deliberação por parte daqueles que sofrerão os efeitos de sua imple-

14 A definição de ator para Markusen (2005, p. 58) parece bem útil: "Defino atores como instituições que funcionam como agentes decisórios, empreendedores que decidem estabelecer ou criar firmas em determinados locais e trabalhadores que tomam a decisão de migrar. (...) Outros atores são, também, importantes - entidades de caráter não lucrativo, cooperativas, grupos comunitários, associações profissionais, organizações religiosas, indivíduos e, acima de tudo, o Estado." 
mentação, o que inclui levar em conta as opiniões dos atores envolvidos em instâncias participativas de gestão urbana. Por isso, urge o desenvolvimento de um conhecimento relacional capaz de apreender criticamente a complexidade geográfica contemporânea. Considerando-se que esta se apresenta como um mosaico de situações em movimento, esse conhecimento requer, assim, a operacionalização concomitante da sucessão e da simultaneidade dos eventos, a valorização do sujeito de conhecimento e suas práticas espaciais no mundo sensível, cotidiano. Arrais (2008, p.87) assim sintetiza a situação: "há um déficit entre os processos sociais que insistem em mostrar a integração regional e o processo político, que insiste em fragmentar, devido a nossa geometria do poder, o espaço integrado".

A articulação entre os territórios estratégicos, as macrorregiões e os novos pólos regionais/locais cumpre, assim, importante papel na organização territorial das estratégias e das ações. Sob um ângulo autonomista do planejamento, o território - e tudo aquilo que ele articula e gera econômica, social, ambiental e politicamente - é uma das premissas essenciais para a construção de estratégia social inclusiva e integradora de desenvolvimento. Essa clareza tem de advir de um debate democrático e de natureza essencialmente política e não restrita apenas às questões técnicas. Tal enfoque deve admitir a possibilidade de que, na atual situação em que um país como o Brasil se encontra, o Estado pode criar condições de protagonizar ações e implementar políticas públicas que favoreçam o grau de autonomia dos menos favorecidos, dependendo da conjuntura de forças que se queira priorizar. 


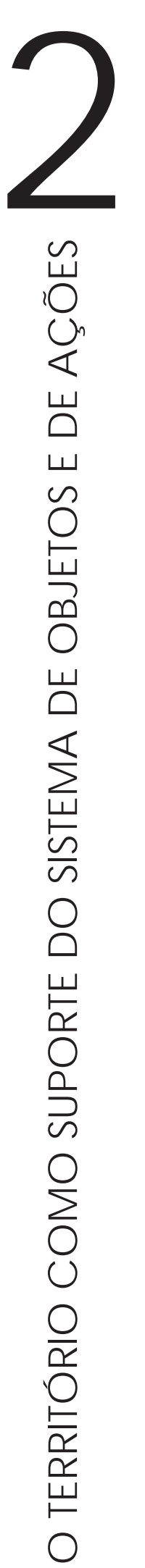

Os objetos não têm por si mesmos uma história, nem uma geografia. Mas sua existência histórica depende de sua inserção numa série de eventos - uma ordem vertical - e sua existência geográfica é dada pelas relações sociais a que o objeto se subordina, e que determinam as relações técnicas ou de vizinhança mantidas com outros objetos - uma ordem horizontal. Sua significação é sempre relativa

Milton Santos (2008, p.102) 
62 | CAṔ́tULO 2 


\section{O TERRTÓRIO COMO SUPORIE DO SSTIEMAS DE OBJ EIOS E DE AÇÕES}

Os usos do território se fazem de maneira diferenciada conforme sejam os objetos do seu suporte físico aliados às ações implementadas pelos homens. A técnica ${ }^{15}$ entra como elemento fundamental na intermediação entre esses dois sistemas, objetos e ações, definindo formas de apropriação e evolução, conforme sejam dadas as adaptações e transferências tecnológicas às condições preexistentes. O território é necessário como suporte material da organização da vida e lhe fornece uma de suas bases simbólicas.

Milton Santos (1977) observa que as rugosidades espaciais vão diferenciar os lugares, capacitando-os, de maneira desigual, a participar dos sucessivos processos de modernização. A natureza heterogênea do território, produzida na existência local, envolve necessariamente elementos técnicos de estoque, os fixos (objetos) e de fluxos (ações), que, combinados historicamente a partir de uma base geomorfológica, constituem um conjunto de efeitos cumulativos e de escala, definindo lugares distintos, mas que exercem influência em uma determinada área ou região de entorno. As implicações desse processo cumulativo das ações humanas possibilitam com frequência um desequilíbrio na dinâmica de construção do espaço social, fazendo com que o território se reestruture de forma heterogênea. Num país de economia integrada onde o Estado federado centraliza recursos e decisões, torna-se imperativo avaliar o papel do Estado na organização do espaço, uma vez que o Estado assegura a integração entre fixos e fluxos ${ }^{16}$ na execução da infraestrutura urbana.

Para compreensão do objeto tratado na tese, é importante que se faça uma análise da macroestrutura do território do Espírito Santo de forma mais ampla, para, depois, gradativamente, serem identificados os contextos específicos que constituíram as heterogeneidades regionais do estado. Des-

15 Um produto social adquire um significado superior e pressupõe uma necessidade e uma técnica. A técnica é um produto historicamente construído e vai sendo transmitida, avaliada, aperfeiçoada e se consolida como uma estrutura. A técnica se consolida com a atividade, a medida que se experimenta. Portanto, o espaço social é senão um produto da atividade humana e do trabalho social, intermediada por uma técnica, construído historicamente. (Lefébvre, Henri. Le Materialisme Dialetique.Quadrige. Paris.1940)

16 SANTOS, Milton. A Natureza do Espaço. Técnica e Tempo, Razão e Emoção. 4.ed. São Paulo: Editora da Universidade de São Paulo,2008, p 61-65. 
se modo, estruturam-se, neste capítulo, duas partes: a primeira se destina a conhecer o sistema de objetos e ações que, a partir dos precedentes históricos, possa explicar o porquê das referências sempre tornadas secundárias no território nacional; a segunda análise se refere às ações implementadas pelo planejamento dos anos de 1970/1980 que conformam, hoje, regiões completamente distintas no estado do Espírito Santo, especialmente do ponto de vista econômico e de distribuição de bens e serviços, conferindo à Região Metropolitana de Vitória uma posição de centralidade.

A transformação do território metropolitano no âmbito da modernização industrial demanda uma análise do desenvolvimento da economia do Espírito Santo e da ação do Estado, enquanto agente promotor dessa diversificação econômica. Essa abordagem se faz necessária em face das novas formas de organização do território propostas pelo planejamento estratégico atual, que visa minorar as disparidades regionais, a partir de diretrizes coordenadas por macroestratégias de mercado. Desse modo, para compreender os sistemas de objetos e ações que comandaram mudanças estruturais no território estadual e fazer a conexão de como se deu a inserção do estado na nova dimensão global, um esforço de periodização se faz necessário, pois os usos são diferentes nos diversos momentos históricos.

\subsection{Da ação dos homens}

Uma primeira análise da conformação físico-natural do Espírito Santo preconiza uma leitura do território extremamente diversificada, conjugando paisagens mistas e transitórias, que vão das serras e vales às planícies litorâneas, destacando-se rios e mangues. A riqueza e a alternância de processos geomorfológicos mostra que não é pela ausência de referenciais locais que o estado sempre se manteve à margem do processo de desenvolvimento do sudeste brasileiro, mesmo considerando que as características fisiográficas de um território, por mais que possam ser adaptadas pelas obras de engenharia, serão sempre importantes condicionantes da forma urbana, do seu desenvolvimento e das relações que se estabelecem no seu interior. Há que prevalecer a hipótese de que as ações dos homens sobre um dado território estão condicionadas pelas técnicas, que são mais amplas e determinantes de sua condição ou representatividade espacial do que seus condicionantes naturais. 
O estado do Espírito Santo se configura por uma pequena extensão territorial inserida na região Sudeste do Brasil, perfazendo um total de 45.597 $\mathrm{km}^{2}$, o que corresponde a apenas $0,53 \%$ de todo o território nacional, e apresentando uma população no ano de 2009 em torno de 3.487 .199 habitantes ${ }^{17}$, distribuída em quatro macrorregiões administrativas e doze microrregiões. Considerando a população brasileira em torno de 191.506.729 habitantes (contagem IBGE/2009), o percentual do estado corresponde a apenas $1,82 \%$ deste total, portanto, percebe-se que o estado passou a ter um relativo crescimento demográfico em período recente com a industrialização. $\mathrm{O}$ aspecto misto da configuração do território do Espírito Santo confere-lhe, à primeira vista, notável representatividade na paisagem, dada a conjugação e o jogo de transição entre diferentes formas e relevos.

A geomorfologia do território capixaba é caracterizada por três faixas longitudinais que atravessam todo o seu território: a zona serrana é predominante e abrange cerca de $77 \%$ de sua superfície; a zona de tabuleiros (com altitudes abaixo da cota de $200 \mathrm{~m}$ ) e a zona das baixadas litorâneas (MORAES, 1974). Desse modo, não é difícil identificar, no sentido longitudinal, duas regiões diferenciadas: uma, notadamente, nordestina que se relaciona naturalmente ao extremo sul da Bahia, e outra notadamente relacionada ao sudeste brasileiro, a que se associa ao norte fluminense. Já no sentido transversal, há uma outra região notadamente interiorana, que se relaciona diretamente ao "mar de morros" mineiro (Figura1). Nesse sentido, podemos falar em três regiões diferenciadas, que supõem, a cada direção, o desenho característico dos estados limítrofes e que, ao se encontrarem no conjunto da baía de Vitória, configuram uma área especial de convergência e de transição em todos os sentidos (MONTEIRO, 2008, p.54).

A orla litorânea apresenta uma extensão de $416 \mathrm{~km}^{2}$. O litoral sul espíritosantense, embora também apresente o conjunto de sedimentos e tabuleiros em seus $130 \mathrm{~km}$ de extensão, traz como traço comum as pontas de amarração dos cordões litorâneos e dos cursos d'água, a saber: a ponta do Jucu e da Fruta, ambos no município de Vila Velha, as pontas do Una

17 Fonte: IBGE. Dados de população contagem 2009 com base no Censo IBGE 2000. 


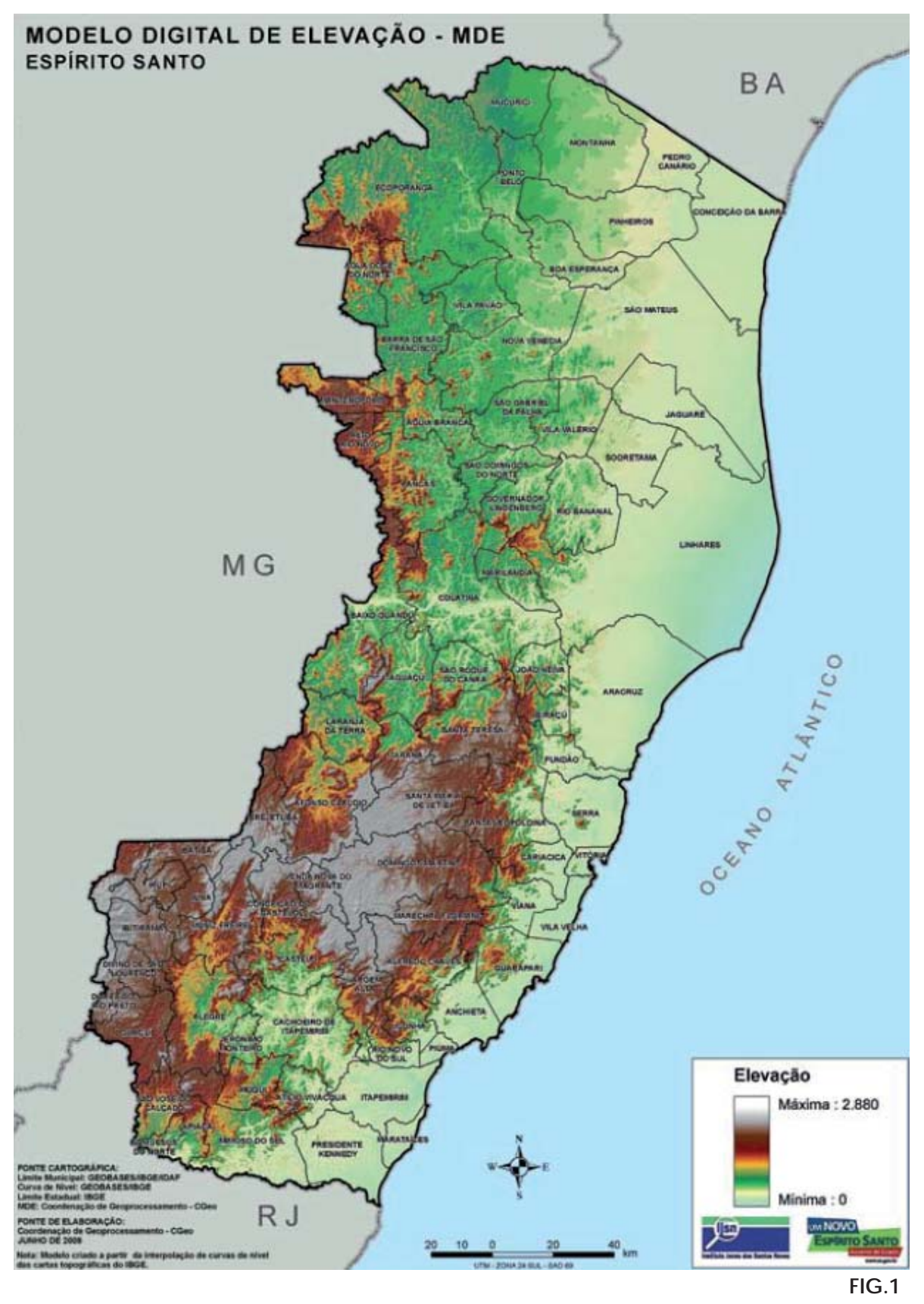

RG.1

Carta Altimétrica do Espírito Santo. Fonte: IJ SN

(Guarapari), Anchieta, Piúma, Barra do Itapemirim e Marataízes. Entre os limites da Baía de Vitória e o município de Anchieta, a formação da costa litorânea favoreceu a implantação de três portos: Porto de Vitória; Porto de Capuaba (Vila Velha) ambos no canal da Baía de Vitória, e Porto de Ubu, este último no município de Anchieta. Ainda nesse trecho, destacase a presença de manguezais junto a estuários dos rios Santa Maria (Vitória), Jucu, Guarapari, Benevente (Anchieta) e Itapemirim. 


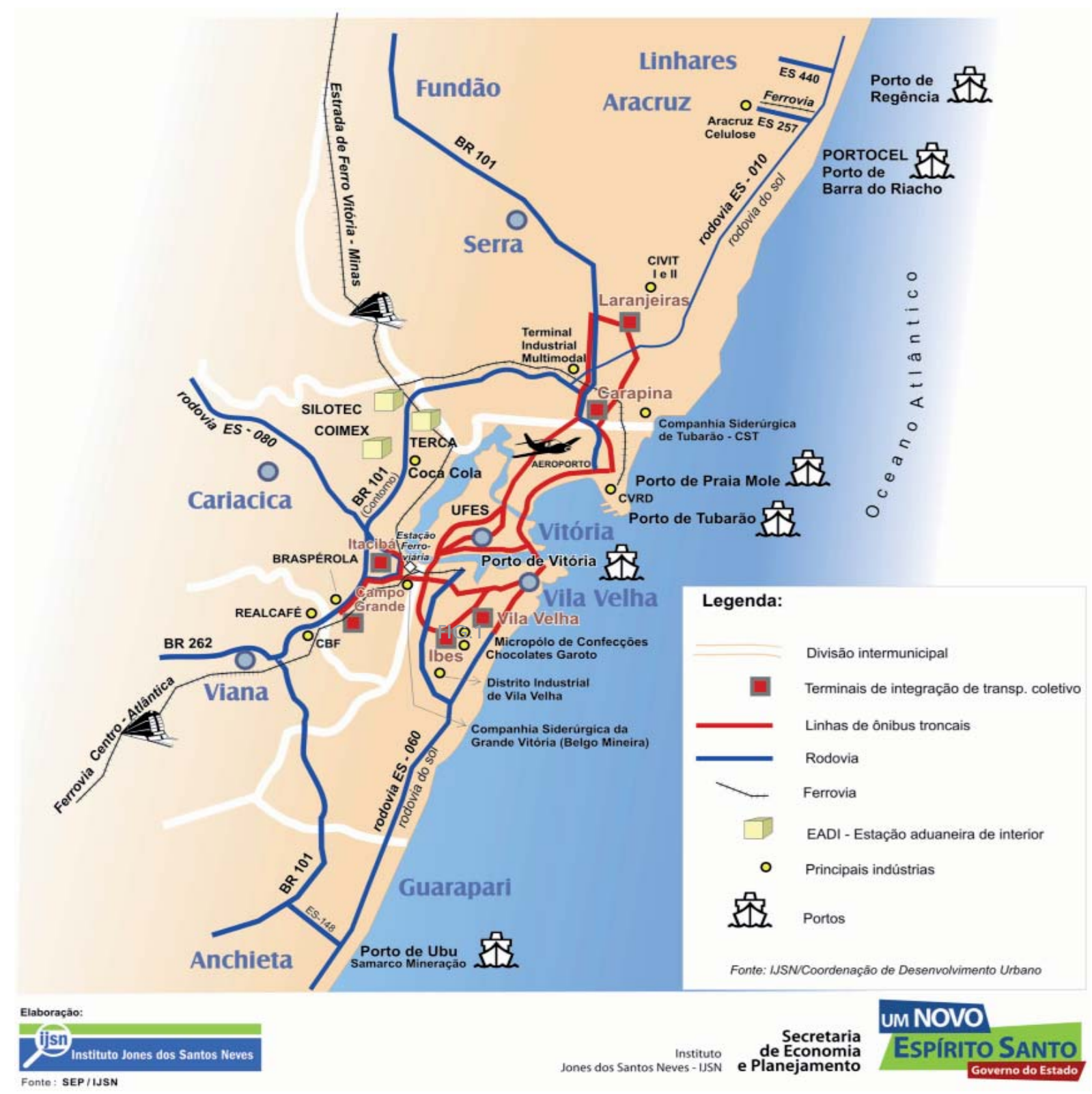

FG.2

Localização dos portos no litoral do Espínto Santo. Fonte: IJ SN

O litoral norte se configura no trecho mais recortado da costa capixaba, sendo seu desenho mais diversificado. Até a ponta de Tubarão ${ }^{18}$, podemos encontrar arranjos variados dos tabuleiros e terrenos cristalinos do Atlântico. Os $60 \mathrm{~km}$ do trecho entre Barra do Riacho (município de Aracruz) e a ponta de Tubarão são caracterizados por maior proximidade dos tabuleiros junto ao mar e por uma descontinuidade em seu relevo. Este tipo de geomorfologia favoreceu a implantação de quatro portos neste trecho, tais

18 A ponta de Tubarão está localizada nos limites entre os municípios da Serra ( ao norte) e de Vitória e nela, estrategicamente, situa-se o complexo Porto e Siderúrgica de Tubarão ( Arcelor Mittal). 
como, Porto de Regência (Linhares), Portocel (Barra do Riacho), Porto de Praia Mole e Porto de Tubarão (Figura 2). Portanto, considerando um pequeno trecho do litoral, desde a região norte na altura de Linhares, até o município de Anchieta, cuja extensão perfaz aproximadamente $160 \mathrm{~km}$, concentram-se sete portos, estando a Região Metropolitana da Grande Vitória em uma posição de convergência e quase equdistante entre os portos do norte e do sul. Como se vê, a posição geográfica do território do Espírito Santo define um caráter eminentemente marítimo, favorecendo o desenvolvimento das atividades portuárias.

A região interiorana do Espírito Santo configura-se numa paisagem predominantemente serrana, marcada por formações geológicas antigas do précambriano, onde se destaca a presença das rochas cristalinas (MORAES, 1974). A existência de duas serras-mestras que cortam transversalmente o território, o sistema da serra dos Aimorés, ao norte, e o sistema da Serra do Caparaó ou Mantiqueira, conjugadas aos rios que cortam o estado no sentido oeste-leste indo desembocar no litoral, constitui uma alternância de paisagens extremamente interessante e diferenciada. A região central serrana do estado apresenta temperatura mais amena, o que contribuiu para o estabelecimento da cultura cafeeira durante longo período no estado. Dos cursos d'água, o grande destaque fica por conta da presença do rio Doce - o maior e o mais importante - e do rio Santa Maria - principal rio que deságua na baía de Vitória. A Baía de Vitória é um braço de mar que penetra profundamente pelo continente, tornando-se um espaço favorável à navegação e ao comércio portuário.

No momento atual, as referências geográficas do território do Espírito Santo, especialmente os condicionantes geográficos do litoral sul, foram importantes indicadores para a tomada de decisões com fins à ampliação da atividade siderúrgica. Os portos tornam-se estruturas extremamente interessantes para a economia do estado junto às redes globais. Tais estruturas são consideradas prerrogativas favoráveis à instalação de objetos técnicos que prescindam de sistemas logísticos aliados à configuração territorial e respectivos sistemas geográficos. Assim, a cada novo período, mudam-se os conceitos e, conforme sejam as demandas do processo produtivo, novas referências territoriais são valorizadas e incorporadas ao processo produtivo. 
A base das periodizações não é constituída apenas pelas relações sociais. Estas raramente tomam em consideração a materialidade e os dinamismos do território; portanto, não bastam como dado explicativo (SCHERER,1987). Considerando tal premissa, é preciso, então, pensar as técnicas como formas de fazer e regular a vida, e ao mesmo tempo, pensá-las como cristalização dos objetos geográficos, pois estes têm um papel de controle devido ao seu tempo próprio, que modula os demais tempos (SANTOS; SILVEIRA 2005, p.24). Daí, a importância de se resgatarem os fatores e as sobreposições das divisões do trabalho, selecionando as variáveis preponderantes que foram capazes de imprimir mudanças no âmbito da totalidade do território estadual.

Durante pelo menos quatro séculos, o estado do Espírito Santo evoluiu em sua conformação espacial mediante uma contribuição pequena de recursos da técnica. Tal fator determinou, historicamente, uma representatividade quase nula do Espírito Santo no contexto nacional, não conseguindo alavancar o mesmo destaque que impunha a presença dos estados vizinhos que compõem a Região Sudeste, na qual o Espírito Santo se insere. Embora tenha sido, um dia, considerada a mais abastada da costa, a capitania do Espírito Santo sempre teve poucos recursos devido principalmente aos obstáculos, tais como a presença de grupos indígenas bravios e a presença dos contrafortes da Serra da Mantiqueira - o que dificultou sobremaneira a ocupação do seu interior no período colonial. $O$ fato que poderia privilegiar o uso do território do Espírito Santo, com o avanço das bandeiras paulistas, no final do século XVII, e a consequente descoberta do ouro e de diamantes no sertão do Brasil (estados de Minas Gerais e Goiás), não ocorreu. Mesmo sendo o Espírito Santo a saída mais próxima de Minas Gerais prevaleceu a exportação das riquezas minerais junto à cidade do Rio de Janeiro, posteriormente constituída sede da Colônia portuguesa. Ao território capixaba coube apenas servir como estratégia de defesa aos eventuais ataques que pudessem ocorrer ao estado vizinho de Minas Gerais.

No século XIX, inicia-se a ocupação da região sul do estado e difunde-se a produção cafeeira com base na grande propriedade e nos moldes escravistas, presentes nos estados de Minas Gerais e Rio de Janeiro, conforme 
descreve Taunay:

Ao mesmo tempo em que os espírito-santenses lutavam por expandir as suas lavouras de café pelas exíguas áreas litorâneas, os fluminenses que já haviam alcançado o vale do Paraíba, juntamente com os mineiros da Zona da Mata, iriam penetrar pela primeira vez o planalto interior através das cabeceiras dos rios Itabapoana e Itapemirim, partindo respectivamente de Itaperuna (RJ) e Muriaé (MG); assim, as zonas interioranas do Espírito Santo, no seu trecho Sudeste, tão temida ainda no séc. XIX em função das tribos indígenas que por aí vagavam, iriam ser penetradas do interior para o mar por mineiros e fluminenses, que constituiriam as primeiras grandes fazendas da província, nas mesmas bases de suas respectivas áreas.

(TAUNAY Apud CAMPOS:2002,p.32)

A vinda de mineiros e fluminenses para ocupar o sul do estado coincidiu com a emergência do período de crise do trabalho escravo. Em meados do século XIX, a cada nova restrição ao tráfico negreiro, estreitavam-se as bases de reprodução da estrutura produtiva então vigente, ou seja, o latifúndio. A alternativa à crise do trabalho escravo foi o incentivo à imigração pelo governo federal. O imigrante tinha por garantia do governo o acesso à terra, condição imprescindível requerida por eles. $\mathrm{Na}$ análise de Campos (2002), a política de imigração como alternativa à crise do trabalho escravo, ao contrário do que comumente se supõe, resultou no aumento da ocupação territorial para o interior do Espírito Santo e, principalmente, na ampliação do cultivo do café que tinha por base a pequena propriedade e as relações de trabalho familiar. A vinda dos imigrantes, sobretudo italianos e alemães, que se estabeleceram em regiões praticamente intocadas da região serrana no interior do estado e fragilmente ligadas aos núcleos do litoral, fez com que se desenvolvessem as chamadas "ilhas culturais", cuja diversidade étnica mostrou a maneira como eles se adaptavam ao novo ambiente.

Os rios, nessa época, também eram as principais vias de comunicação para o acesso do litoral às regiões cafeeiras do interior e serviram de instrumento para a ocupação do território e para o escoamento da produção. É importante ressaltar aqui que grande parte da imigração italiana adentrou o interior do Espírito Santo por meio do rio Benevente, principal 
via navegável do município de Anchieta, para acesso às terras férteis da região de Alfredo Chaves, no último quartel do século XIX, difundindo a cultura cafeeira em pequenas propriedades. Foi nessa época que a vila de Benevente - atual sede do município de Anchieta - alcançou um dos momentos de maior prosperidade de sua história. Era grande a produção daquela importante região, que incluía, além de Alfredo Chaves, o que seriam hoje também as terras de Iconha até Piúma; tudo pertencia à região de Benevente. E o porto da cidade de Anchieta, que serviu de entrada para os imigrantes, tornou-se corredor de saída para a exportação do café de toda essa próspera região.

Em fins do século XIX, no auge da produção cafeeira, a ocupação territorial havia formado regiões produtivas no Espírito Santo em torno de cidades que não se comunicavam entre si por transporte terrestre regular. As três principais regiões eram: a Sul, polarizada por Cachoeiro de Itapemirim; a Central, convergente para Vitória e a Região Norte, produtora de mandioca e polarizada por São Mateus (CAMPOS, 2002). Nesta época, era notável o isolamento do território, e todas essas três cidades comer-

FG.3

Cidades-polo isoladas no Espínito Santo do século XIX. Fonte: Acervo pessoal

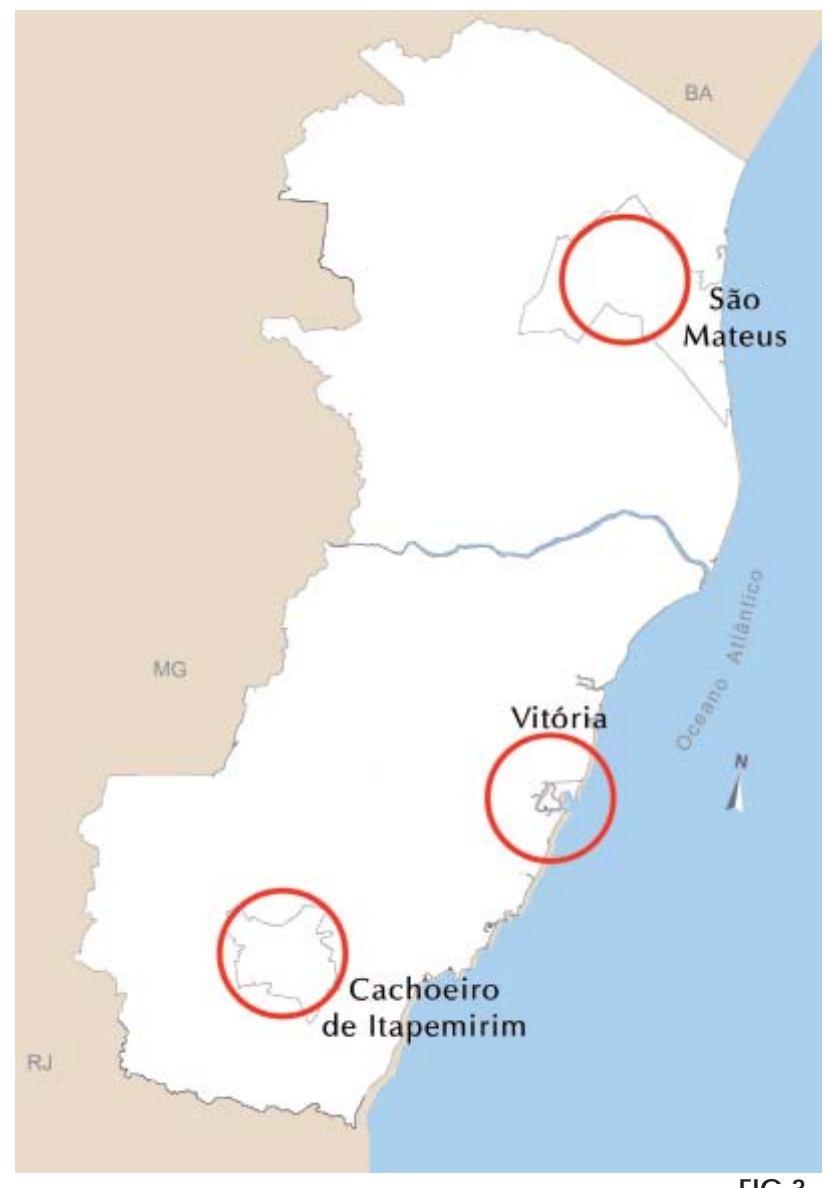

FG.3 
cialmente mais destacadas se comunicavam preferencialmente através do transporte fluvial ou maritimo (Figura 3). Até então, o Espírito Santo vivia fechado regionalmente, e o seu território não se inseria no universo de que o capital nacional/internacional dispunha para se reproduzir.

Alguns estudos defendem a hipótese de que, desde a época áurea do café, a produção cafeeira não convergia para Vitória, e sim era exportada para o Rio de Janeiro. A proximidade física entre Cachoeiro do Itapemirim e o Rio de Janeiro e a sua ligação por intermédio da Leopoldina Railway com a capital federal contribuíam para que o café produzido no sul do Espírito Santo fosse exportado pelo Rio de Janeiro, como se ele se originasse naquele estado vizinho. As firmas exportadoras do Rio de Janeiro tinham agentes estabelecidos na cidade de Cachoeiro, ao sul do estado, que facilitavam esse desvio da produção. Essa situação acarretou bastante prejuízo de receita para os cofres do Espírito Santo. Apesar de o café ter participado, em determinado momento, com $82 \%$ a $97 \%$ das exportações do estado e de ter sido ele responsável pela terceira colocação do Espírito Santo nas exportações brasileiras, o argumento defendido por Campos é de que o excedente da produção cafeeira não contribuiu para transformar a base produtiva local e nem mesmo migrou para o setor da indústria, mas serviu, sim, para estimular a busca por mercados mais promissores e para investimentos nos centros maiores - Rio e São Paulo -, especialmente no setor imobiliário. Assim, o estado ficou praticamente estagnado economicamente e sem projeção política por quase todo o período colonial até grande parte do século XIX (CAMPOS, 2002, p.41).

No início do século XX, houve no Espírito Santo, uma inserção maior dos sistemas de engenharia e de transportes com a construção de pontes, estradas de ferro e o início de mecanização dos portos. Paralelamente, ocorreu a difusão de novas formas de comunicação. O progresso técnico, ainda que incipiente, fez com que a organização do território fosse se delineando em outros moldes. A base produtiva do estado, que era eminentemente agrícola, apoiada na monocultura do café, passou a ter uma interlocução maior com as atividades comerciais e de serviços, notadamente com a capital, Vitória. Por outro lado, a particularidade natural do território do Espírito Santo favorecia o desenvolvimento das atividades marítimas e portuárias, estabelecendo um vínculo imediato à exportação 
de matérias-primas. Houve um aprimoramento da base portuária estabelecida na cidade de Vitória. Essa condição propiciou um incipiente crescimento econômico à capital, com o aumento de empresas prestadoras de serviços. A cidade de Vitória se manteve eminentemente comercial e prestadora de serviços como sede político-administrativa do governo estadual, além de estar atrelada às atividades portuárias.

Tomando por base indicadores da indústria de transformação para o conjunto do Espírito Santo, observa-se que, até a década de 1960, esse setor não era diversificado e não representava nem 1\% do valor da produção do conjunto da indústria no país. O que se observou foi que o excedente do comércio desenvolvido na capital não vazou para a pequena indústria até os anos de 1960, ou seja, não foi capaz de promover grandes alterações no perfil urbano de Vitória. A conclusão que se tira desses fatos é a de que as condições particulares provenientes da estrutura produtiva no Espírito Santo travaram a diversificação econômica. Assim, o estado do Espírito Santo, ocupou durante um longo período, uma posição periférica na economia e na política, tanto na época colonial quanto no Império e mesmo na primeira metade do Brasil Republicano.

De certo modo, podemos afirmar que o Porto de Vitória, e respectivas atividades correlatas, foi o principal promotor da urbanização da capital até a década de 1960, quando, então, a política de erradicação do café ${ }^{19}$, de iniciativa do governo federal, acrescentou novas características à urbanização da capital. A queda nos preços internacionais do café gerou novas alternativas à superação da crise generalizada que se instalou no estado. $\mathrm{O}$ governo federal criou condições favoráveis a um processo gradativo de inserção da economia local na dinâmica nacional e internacional por meio da indústria. Iniciava-se o período de injeção de recursos externos e de instalação das estatais, em consonância, na época, com a política federal para o setor.

A partir da segunda metade da década de 1960, grandes planos nacionais de desenvolvimento levaram a cabo mais uma etapa de modernização do

19 O café foi o grande empregador de mão-de-obra até a década de 1960 no Espírito Santo, respondendo pelo emprego de $67 \%$ da população economicamente ativa. A política erradicação do café foi realizada nos períodos entre 1961-62 e em 1966-67. 
território nacional com a finalidade de integrar o país ao movimento de internacionalização. O Programa de Ação Econômica do Governo (19641966), segundo Otávio Ianni (1971), procurou reintegrar o subsistema econômico brasileiro ao sistema capitalista mundial. O planejamento estatal consolidou-se como instrumento básico de implementação das políticas públicas. Foram elaborados, na década de 1970, os Planos Nacionais de Desenvolvimento - PNDs, que explicitaram os setores estratégicos de investimento estatal e controle de atividades produtivas no território. Instalou-se no país, entre as décadas de 1970 e 1980, uma dinâmica particular que transformou a configuração espacial, com o desenvolvimento do sistema de transportes, telecomunicações e energia. Observa-se, assim, uma mudança na estrutura da produção material que passou a abranger todo o território e se tornou mais intensa e diversificada, gerando mudanças na circulação e no consumo. Juntos, esses processos levaram a uma maior integração do território e construíram a base de sua fluidez (circulação e consumo). Para Santos, “essa fluidez possibilitou que o espaço nacional se tornasse um terreno propício para os capitais internacionais. Daí novas temporalidades hegemônicas, exigentes de uma frenética circulação, poderem instalar-se no território brasileiro". (SANTOS, M; SILVEIRA, L,2005,p.336)

No contexto nacional das políticas federativas, a indústria difundiu-se em estreita relação com o tamanho das populações concentradas. O eixo Rio - São Paulo despontou como uma área de acumulação da produção industrial, permitindo uma diversificação da atividade fabril, que beneficiou igualmente os estados da região Sul. São Paulo tendia a ultrapassar o Rio de Janeiro, sobretudo, pela maneira diferente como se organizava a sua zona de influência, crescendo em dinamismo. Nessa perspectiva, o sistema formado e desigualmente distribuído concentrou-se nas regiões Sudeste e Sul. Essa maior densidade do meio técnico em uma área contígua do território, foi denominada, em Milton Santos e Ana Clara Torres Ribeiro (1979) de "Região Concentrada." 20 A fluidez do território, acentuada na Região Concentrada, aumenta a acessibilidade físico-financeira dos indivíduos e aprofunda a distribuição produtiva, beneficiando a ação das

20 A Região Concentrada considerada pelos referidos autores, abrange os Estados de São Paulo, Rio de Janeiro, Minas Gerais e Espírito Santo, Paraná, Santa Catarina e Rio Grande do Sul, caracterizando-se pela consolidação dos dados da ciência, da técnica e da informação. 
grandes corporações. Essa é a razão pela qual, havendo maior mobilidade na Região Concentrada, é nesta que se realiza, de modo relativamente limitado, uma integração econômica que tem dificuldade para se difundir pelo resto do território. É esse também o embrião da polarização que, nos períodos sucessivos, veio conferir uma primazia à região Sudeste e assegurar a São Paulo um papel inconteste de metrópole econômica do país (SANTOS; SILVEIRA, 2005, p.337-339).

Destarte, com a concentração técnica e econômica verificada preferencialmente nos estados do Sudeste, como São Paulo e Rio de Janeiro, o estado do Espírito Santo iniciou sua projeção no cenário nacional a partir da década de 1970, quando, o estado também se enquadrava no projeto de industrialização, cuja produção - beneficiamento de minério - estava eminentemente voltada para o mercado internacional. A questão da localização favorável ao desempenho das atividades portuárias para escoamento da produção de minério proveniente de Minas Gerais foi o condicionante motriz para estabelecimento do meio técnico, nessa primeira fase da industrialização. Alguns projetos industriais foram priorizados com fins à diversificação da economia. Entretanto, a ocupação efetiva do território espírito-santense ocorreu em período recente ${ }^{21}$ (década de 1980) com o advento dos grandes projetos industriais que caracterizaram um novo tipo de articulação do Estado ao contexto nacional e internacional. Romperam-se, assim, as fronteiras regionais para a expansão do capital.

\subsection{A tec nificação e a constituição desigual do tenitónio do Es- pínto Santo}

\footnotetext{
O cientista deverá, portanto, para ser intelectualmente honesto e para afirmar-se enquanto tal, manter-se vigilante e crítico em face de seus valores, evitando tomar impressões por resultados consolidados, duvidando das próprias certezas provisórias, insistindo em examinar um problema a partir de diferentes ângulos, expondo-se de muito bom grado ao teste do exame empírico pormenorizado e extraindo
}

21 Segundo Campos (2002:32), em 1920, as terras apropriadas correspondiam a 28,1\% da área total do Estado; em 1960 representavam 63\%; e por volta de 1970, a fronteira agrícola havia se esgotado. A região norte foi a que mais demorou a ser ocupada. Esse processo lento de ocupação do território, faz parte do movimento que originou o deslocamento do colono no território a partir da necessidade de recorrer a novas terras, à medida que constatava o uso e esgotamento das terras ao sul do estado. 
humildemente as lições do teste supremo, o da história.

(SOUZA, 2006, p.98)

A reflexão sobre o comportamento do desenvolvimento industrial no Espírito Santo nos faz admitir que a estrutura do modelo se funda nos blocos de economias integradas às atividades exportadoras e a outras como complemento de atividades importadoras. Esse sistema industrial formado em torno de um mercado abastecido no exterior é específico das economias dos países periféricos. Conforme argumenta Furtado, a evolução dos termos de intercâmbio tende a ser desfavorável à periferia do sistema - isto é, aos países fornecedores de produtos primários -, e a acumulação continua a concentrar-se nos países centrais (FURTADO, 1996, p.20). Esta é a argumentação de Furtado para o enfraquecimento dos Estados frente às ações oligopolistas e coordenadas das empresas:

A ação dos Estados nacionais, no centro do sistema, ampliou-se em determinadas direções para assegurar a estabilidade interna, sem a qual as fricções internacionais seriam inevitáveis; mas por outro lado, modificou-se qualitativamente, a fim de adaptar-se à atuação das grandes empresas estruturadas em oligopólios, que têm a iniciativa no plano tecnológico e são o verdadeiro elemento motor no plano internacional.

(FURTADO,1996,p.59)

O atual projeto de modernização e ampliação do setor industrial capixaba, em especial o siderúrgico, significa um aprofundamento da estrutura produtiva já em andamento desde a instalação dos Grandes Projetos no Espírito Santo, nos anos de 1970. O conhecimento dos processos que impactaram o território metropolitano, definindo e fortalecendo uma hierarquia regional numa primeira fase da industrialização, torna-se imperativo para a compreensão da forma como o Estado organiza o território para instauração da nova base técnica-científica, nesse segundo momento, em que a industrialização tende a ser largamente ampliada.

O escopo dos Grandes Projetos dos anos de 1970/1980 apoiava-se na perspectiva de quatro grandes grupos voltados predominantemente para o mercado externo: o complexo siderúrgico, o complexo naval, o complexo paraquímico e o complexo portuário. Quase todos esses projetos 


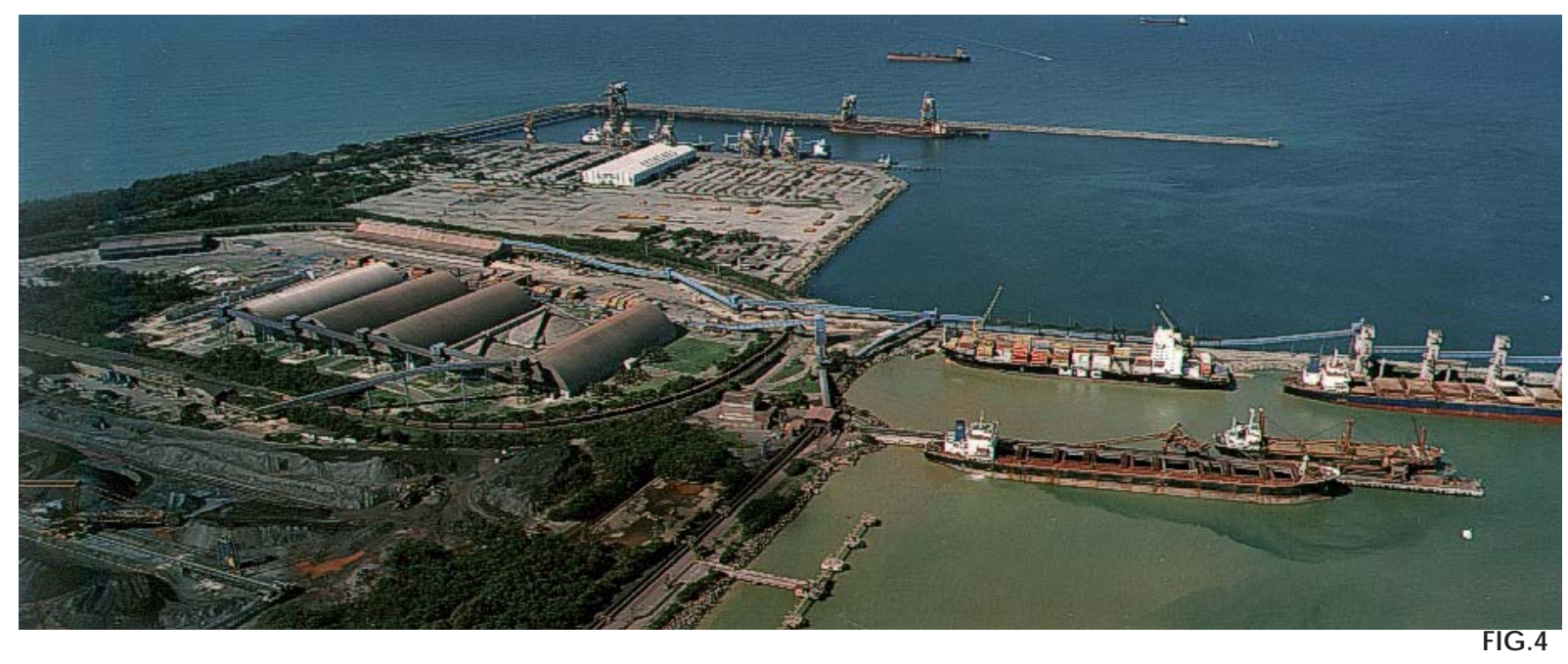

FG.4

Companhia Sidenúrgica de Tubarão (CST) e respectivo porto. A sua localização privilegia as operações de logística; entretanto, causa muitos problemas à região metropolitana com a emissão de partículas de pó de minério. Fonte: Acervo pessoal. se tornaram realidade, com exceção do complexo naval. Vale lembrar que o Espírito Santo abrigava a sede da Companhia Vale do Rio Doce desde os anos de 1960, quando já operava o transporte do minério pelo Porto de Tubarão. O governo estadual antecipou-se à concretização do Projeto Siderúrgico de Tubarão (CST), localizado no município da Serra, contíguo à Vitória. Em 1974, criou ainda um distrito industrial no município da Ser$\mathrm{ra}^{22}$ - o Centro Industrial (CIVIT) - visando atrair indústrias para o Estado por meio da venda a preços subsidiados, dos módulos industriais. A concretização desde distrito, contíguo à área prevista para a instalação da Companhia Siderúrgica de Tubarão, resultou na transformação do setor norte da Grande Vitória em área preferencial para instalação de projetos industriais e residenciais.

A Companhia Siderúrgica de Tubarão (CST), maior produtora mundial de semiacabados de aço, foi constituída em junho de 1976, como uma jointventure de controle estatal e capital misto, com a participação minoritária dos grupos Kawasaki, do Japão, e Ilva (ex-Finsider), da Itália; porém, a sua operação começou apenas em novembro de $1983^{23}$. A Companhia é servida por uma malha rodo-ferroviária: Estrada de Ferro Vitória-Minas e Ferrovia Centro - Atlântica (antiga Rede Ferroviária Federal) e as Ro-

22 O município da Serra faz limite como o município de Vitória, ao norte, e integra a RMGV. O seu território abriga grandes plantas industriais, e, em especial, a Companhia Siderúrgica de Tubarão (CST). O município teve um crescimento demográfico além do esperado, com uma taxa de crescimento populacional de $16 \%$ ao ano, com ocupação espraiada e com interstícios vazios, o que propiciou novas invasões e/ou ocupações irregulares. Devido à dispersão desses empreendimentos e à rarefeita ocupação de grande número de loteamentos, registraram-se importantes descontinuidades do tecido urbano, que ocasionavam extensos vazios territoriais.

23 Disponível em <www.CST.com.br/perfil/história >. Acesso em maio de 2009 
dovias BRs - 101 / 262. A Companhia Siderúrgica de Tubarão (CST) e respectivas atividades correlatas, além de gerar empregos diretos, teve um efeito multiplicador na prestação de serviços indiretos, o que influenciou na formação da classe média da Grande Vitória, elevando o potencial do mercado comprador do setor imobiliário. Por outro lado, a instalação da siderúrgica na capital intensificou as migrações, que se direcionaram prioritariamente para Vitória e municípios adjacentes. Como a capital - Vitória - está restrita à condição de ilha e não teve como acolher em seu território a grande massa de migrantes, instalou-se no município e seu entorno um processo de urbanização por meio de loteamentos irregulares e invasões, espraiando-se entremeado por vazios intersticiais.

Apesar da perspectiva de geração de empregos para absorção de grande número de migrantes, essa perspectiva não se realizou potencialmente, ou seja, os trabalhadores não especializados só foram absorvidos na primeira fase da construção da CST, uma vez que a siderurgia é grande demandante de mão de obra qualificada. De qualquer modo, a CST criou e consolidou sua presença no território capixaba, passando por grandes ampliações, que foram intensificadas após a sua privatização em 1992. A partir daí, a siderúrgica passou a ser controlada por grupos nacionais e estrangeiros ${ }^{24}$.

Uma nova divisão territorial do trabalho esboça-se no Brasil, a partir da necessidade de transformar os minérios, de produzir derivados de petróleo e, a um só tempo, de substituir esse recurso em alguns setores da circulação. É o momento de implantação de complexos e pólos industriais em diversas regiões do país.

(SANTOS, M; SILVEIRA, L., 2001, p.48-49)

Além desses projetos industriais instalados no entorno da capital, o com-

24 A Companhia diversificou a sua produção, em 2002, com a implantação de um Laminador de Tiras a Quente (LTQ), que incorpora a mais avançada tecnologia disponível no mercado. Já em 2004, a CST consolidou a otimização da sua produção para 5 milhões de toneladas/ano (placas e bobinas), com a finalização da montagem da Central Termelétrica 4 (CTE 4), o que garantiu também a autossuficiência energética da CST, mesmo com a operação do LTQ. Em 2003, teve início o Plano de Expansão da produção para 7,5 milhões de toneladas/ano, projeto anunciado à sociedade com a presença do Presidente da República, Luiz Inácio Lula da Silva. Serão investidos, ao todo, recursos da ordem de US\$ 1 bilhão, com a implantação de novas unidades industriais com vistas à retomada do mercado internacional de placas de aço. A publicação do primeiro Relatório Ambiental auditado no Brasil, além do início da Certificação de empregados pela ABM dentro do Programa Nacional de Certificação de Operadores(PNQC), também marcaram o ano de 2003. (Relatório Arcellor Mittal. Disponível em www.cst.com.br. Acesso em junho 2009 
plexo paraquímico já previa a instalação da fábrica Aracruz Celulose ${ }^{25}$ a noroeste da capital, instalada no município de Aracruz, cujo circuito produtivo baseava-se no plantio, fabricação e exportação de celulose. A fábrica da Aracruz dista cerca de $80 \mathrm{~km}$ de Vitória e situa-se imediatamente ao norte da Região Metropolitana de Vitória, tendo iniciado suas operações em 1972. O lugar apresentava boas condições para a monocultura com base no plantio de eucalipto e topografia plana favorável à mecanização. Por estar próxima à costa, a localização da fábrica facilitava o escoamento da produção pelo porto de Barra do Riacho-ES.

A fábrica da Aracruz Celulose atingiu em 1978, uma produção de quatrocentas mil toneladas por ano, destinada à exportação. Devido à crescente demanda para o plantio, a empresa passou a adquirir terras nos municípios vizinhos, especialmente no norte do Espírito Santo, o que desencadeou conflitos com proprietários e uma forte pressão por aquisição de terras. ${ }^{26}$ O Estado exerceu um papel fundamental para o desempenho da indústria de celulose, instituindo programas de isenções fiscais às exportações. $\mathrm{Na}$ década de 1990, a Aracruz Celulose chegou a produzir 1,24 milhões de toneladas de celulose por ano, sendo que 98\% tinham como destino o mercado externo ${ }^{27}$.

A instalação da fábrica da Aracruz causou vários problemas de ordem social e ambiental. Além de ter sido responsável por gerar forte no processamento da celulose forte odor que se estendeu por toda a região até atingir a capital. No início de sua operação, o plantio de celulose em grandes áreas dizimou florestas e invadiu terras indígenas, gerando conflitos sobre

25 A Aracruz Celulose possui operações nos estados do Espírito Santo, Bahia, Minas Gerais e Rio Grande do Sul, e é a maior produtora mundial de celulose branqueada de eucalipto. A empresa utiliza exclusivamente plantios de eucalipto para produzir celulose de fibra curta de alta qualidade, empregada na fabricação de ampla gama de produtos de consumo, incluindo papéis sanitários de primeira linha, papéis de imprimir e escrever de qualidade superior e papéis especiais de alto valor agregado.

26 Segundo denúncias de algumas ONG's capixabas, esta empresa desmatou a área de Mata Atlântica no local de construção da fábrica, e expulsou aldeias indígenas inteiras de suas terras para ocupá-las com as plantações de eucalipto. Também há denúncias de práticas de coação da empresa sobre os proprietários de terra, que foram obrigados a vender suas terras para a Aracruz Florestal, subsidiária da Aracruz Celulose.

27 Fonte de dados: JOLY, Carolina. Especialização Produtiva do Território e o Circuito Espacial Produtivo de Celulose em Eunápolis - BA. Dissertação de Mestrado. Faculdade de Filosofia, Letras e Ciências Humanas da Universidade de São Paulo. São Paulo.2007 
a propriedade da terra na região ${ }^{28}$ (Figuras 5,6, 7 e 8). A emrpesa continuou a expandir sua área de atuação em direção ao sul da Bahia, dotando o território de novos e modernos objetos técnicos.

Paralelamente a esse processo de aceleração da industrialização no entorno da capital, observa-se uma mudança na estrutura da produção material, que passa a abranger todo o atual território metropolitano e torna-se mais intensa e diversificada, levando a alterações na circulação e no consumo. As novas relações de trabalho serviram para evidenciar mudanças estruturais na organização da Aglomeração da Grande Vitória. Aumenta significativamente a procura por terrenos urbanos. O município da Serra, base territorial das grandes plantas industriais, teve um crescimento demográfico vertiginoso, com uma taxa de $16 \%$ ao ano. No final da década de 1970, estava de fato consolidada a conurbação das cidades no entorno de Vitória, levando o governo estadual a elaborar o Plano de Estruturação do Espaço (PEE) - Grande Vitória, respaldando de forma jurídica a configuração espacial da urbe expandida, com a criação, em 1977, da Aglomeração Urbana da Grande Vitória.

O Estado não preparou a estrutura de suporte do território de forma condizente com a iniciativa da industrialização. A ilegalidade é implementada pela dinâmica própria de produção da cidade, na medida em que a lei se aplica conforme as circunstâncias e na ausência de alternativas de inserção no mercado habitacional legal. A invasão de terras torna-se, assim, intrínseca ao processo de urbanização, estabelecendo uma correspondência direta entre as áreas ambientalmente frágeis e a localização das favelas na área urbana. A exclusão dos migrantes do mercado de terras formal teve como ápice a invasão de uma grande área na região noroeste de Vitória, na década de 1980, que devastou significativa área de florestas de mangue, hoje denominada Grande São Pedro (BARBOSA, 2005). Em Vila Velha, município ao sul de Vitória, ocorre processo similar com a grande invasão induzida de Terra Vermelha, bem próxima à orla. Essas invasões se caracterizam como marcos da ineficiência e da desestruturação do Estado

28 Dos 18 mil hectares já reconhecidos pela Funai por meio de laudos antropológicos desde 1998, os índios reclamam a devolução de 11 mil hectares, sendo que cerca de 7 mil hectares de terra já foram resgatados. Fonte: LIMA, B. Índios Ocupam Aracruz Celulose, maior fábrica de celulose branqueada do mundo. 2005. Disponível em: < www.midiaindependente.org>. Acesso em 20 jul.2008) 


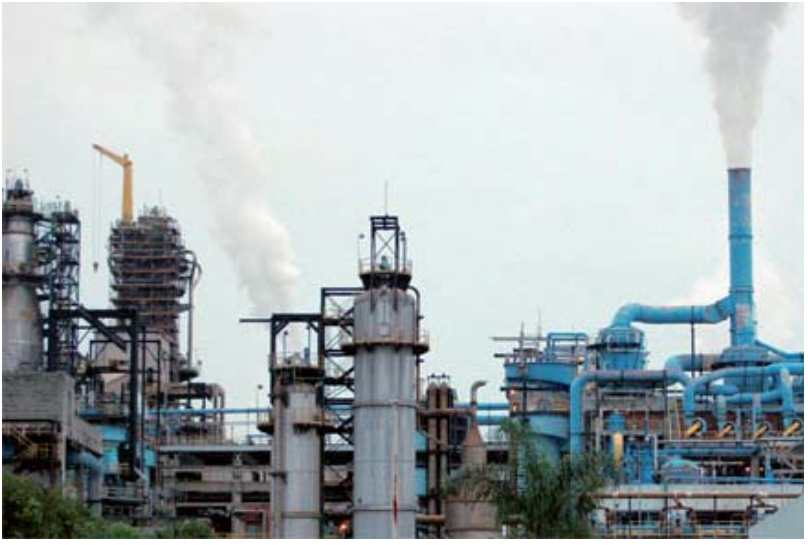

FG.5

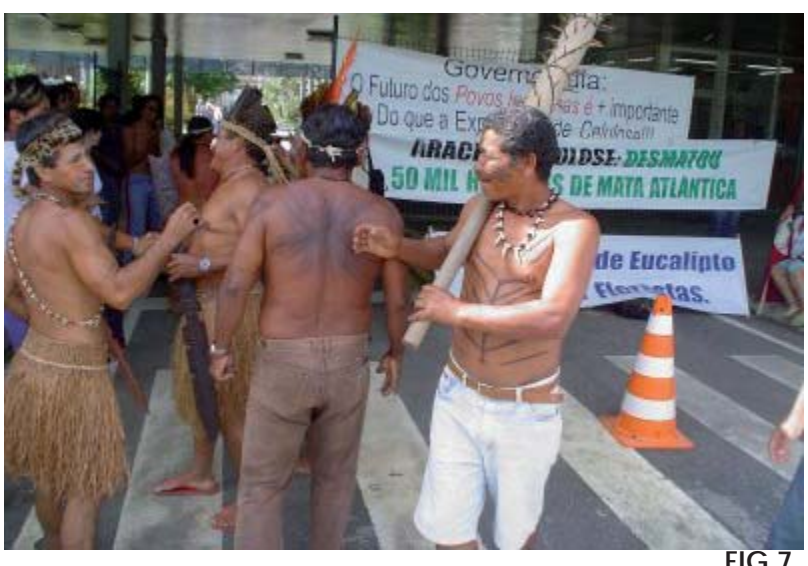

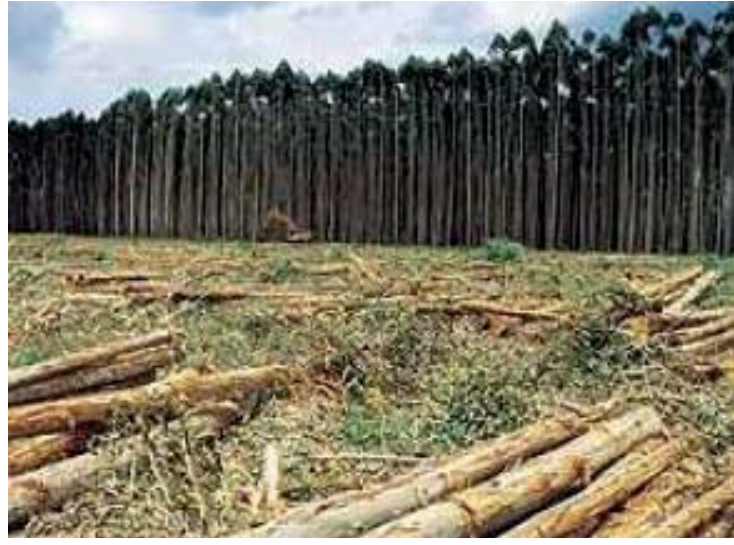

FG.6

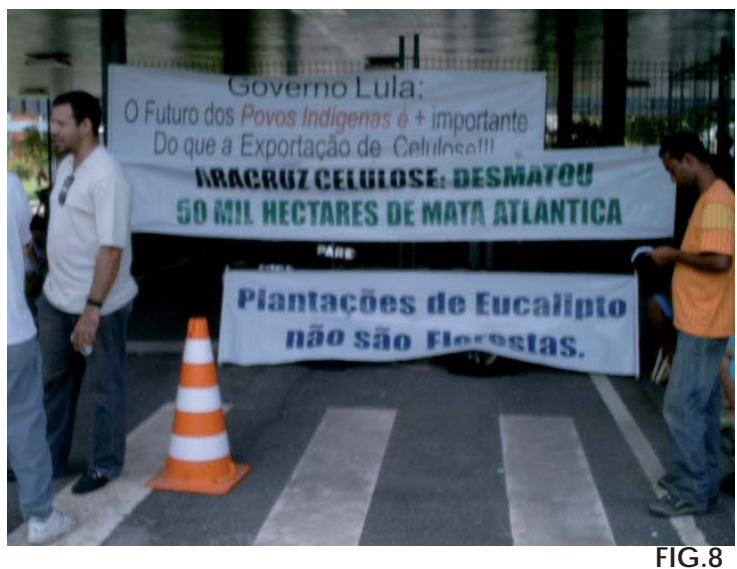

RG.5

Fábrica da Aracruz Celulose. Fonte: Acervo pessoal.

FG.6

Plantio de eucalipto em grandes áreas desmatadas no município de Aracruz. Fonte: < www.econewsbrasil.org $>$. Acesso em julho 2009.

\section{FG.7 e RG.8}

Protesto pela devolução das terras indígenas e contra o desmatamento causado pela fábrica da Aracruz Celulose. Fonte: < www. e c o ne w sb ra sil.org $>$. Acesso em julho 2009. na compatibilização do âmbito social e econômico no território ${ }^{29}$. O Estado não prepara previamente o território de forma a compatibilizar os movimentos econômicos concomitantemente aos sociais, mas, sim, corre atrás dos prejuízos, por vezes, irrecuperáveis, dessa lógica estabelecida e estruturada no plano do mundial.

A política de crescimento estimula progressivamente a produção de bens de capital, para os quais não existe mercado interno. O Estado é, portanto, compelido a adotar uma política de grande potência, favorecendo as maiores empresas sem consideração pelas massas cada vez mais empobrecidas. Nesse período ocorre uma grande ruptura. Importantes capitais fixos são adicionados ao território, em dissociação com o meio ambiente e com a produção. $\mathrm{O}$ capital comanda o território, e o trabalho, representa um papel indireto. Por isso as diferenças regionais passam a ser diferenças sociais e não mais naturais.

(SANTOS, M.; SILVEIRA, L., 2001,p.52)

29 BARBOSA, I. B. Muniz. Modernidade e Assimetrias na Paisagem: a fragmentação de ecossistemas naturais e humanos na Baía Noroeste de Vitória - ES. Dissertação Mestrado. FAU/USP.São Paulo. 2005 
Na década de 1990, houve um forte processo de concentração de capital, por meio de aquisições e fusões das empresas ${ }^{30}$, envolvendo também capital externo. A abertura comercial nesse período foi bastante agressiva. Algumas empresas, como a Aracruz Celulose e a Companhia Siderúrgica de Tubarão, modernizaram sua produção por meio da privatização de terminais portuários e ferrovias, garantindo assim, as vantagens operacionais. Internalizou-se, no estado, uma estrutura de produção de celulose e minério de ferro nos moldes vigentes na indústria mundial, ou seja, com forte concentração de capitais expressa pelo grande porte das escalas de produção e alto grau de integração das empresas na comercialização dos produtos. Iniciou-se, portanto, entre as décadas de 1970 e 1990, um processo dinâmico e evolutivo que levou à formação do meio técnico-científico no estado do Espírito Santo.

Por outro lado, na medida em que as fusões das empresas ampliam a presença de capitais e a subordinação do mercado à globalização, verifica-se, ao mesmo tempo, a aceleração de desequilíbrios regionais. Para Furtado (1996), à medida que se acordou um sistema básico de comunicação e que interesses fundamentais dos dois blocos - países centrais e periféricos foram mutuamente reconhecidos, criaram-se possibilidades para relações econômicas mutuamente vantajosas. Certamente essas possibilidades exploradas rapidamente pelas grandes empresas vieram a se constituir em uma clara indicação da extraordinária capacidade dessas organizações para atuar no plano internacional. Segundo Furtado, parece inegável que os países ditos "periféricos" terão crescente importância nessa evolução, não só porque os países centrais serão cada vez mais dependentes de recursos naturais não renováveis por eles fornecidos, mas também porque as grandes empresas encontrarão na exploração de sua mão de obra um dos principais pontos de apoio para se firmar no conjunto do sistema. O autor afirma:

30 Em outubro de 2005 é criada a Arcelor Brasil. Resultado da união da Companhia Siderúrgica Belgo Mineira, da CST e da Vega do Sul. A Arcelor Brasil já nasce como um dos maiores grupos industriais do Brasil e com capacidade anual de produção de 11 milhões de toneladas de aço. Em 2006, a Arcelor e suas subsidiárias passaram a fazer parte do grupo Arcelor Mittal Tubarão que inicia sua operação em 2007 com um investimento da ordem de US\$ 1 bilhão. Assim foram construídas novas unidades produtivas, que elevaram a capacidade de produção de 5 para 7,5 milhões de toneladas de aço por ano - placas e bobinas a quente, recuperando, assim, a participação da empresa no mercado siderúrgico internacional. A ArcelorMittal Tubarão possui hoje uma área total de 13,5 milhões de $\mathrm{m} 2$, sendo que a usina ocupa 7 milhões de $\mathrm{m}^{2}$. 
Os planos de produção nos países periféricos estão condicionados pela orientação tecnológica, e os mercados internos desses países são moldados à conveniência da ação global da empresa. Nos últimos três decênios, as economias capitalistas industrializadas vêm operando com um grau de coordenação interna muito superior ao que antes se considerava compatível com uma economia de mercado. A verdade é que, a grande empresa tem como diretriz máxima expandir-se, e para isso, ela tende a ocupar posições nas distintas áreas do sistema capitalista.

(FURTADO, 1996, p.65).

Os processos que envolvem circulação e distribuição da produção e serviços exigem uma maior integração dos municípios metropolitanos, e o poder público age no sentido de construir a base da fluidez da circulação, com investimentos em infraestrutura, incremento da logística portuária, aterros ganhos ao mar, construção de pontes, entre outras obras. Essa fluidez possibilitou que o espaço se tornasse um terreno propício para intensificação dos negócios com as empresas multinacionais, assim como favoreceu e alavancou o mercado imobiliário da região metropolitana. A questão primordial que favoreceu o estabelecimento do meio-técnicocientífico no Espírito Santo foi o potencial do modal de transporte portuário do estado, representado por um complexo considerado como um dos mais eficientes do país, operando com sete portos ${ }^{31}$. Os agentes imobiliários apropriaram-se da produção do espaço industrial, e tornaram-se agentes ativos, criando formas espaciais convenientes à lógica do mercado habitacional. O espaço, como território de diversos mercados, revela-se, assim, como alternativa de acumulação.

Este padrão de desenvolvimento econômico baseado nos grandes projetos industriais resultou em alterações profundas na estrutura urbana da aglomeração da Grande Vitória. Nem o poder público, nem a sociedade civil organizaram um sistema de acompanhamento e de avaliação mais criteriosa dos impactos e riscos da industrialização em área urbana. No caso do complexo mínero-siderúrgico, os efeitos ambientais foram bastante abrangentes, tendo em vista a emissão de poluentes de origem gasosa,

31 Os portos: Vitória e Tubarão ( município de Vitória)e Capuaba (Vila Velha); ao norte temos o porto de Praia Mole (município de Serra); Barra do Riacho e Portocel (município de Aracruz); Regência (Linhares); ao sul porto de Ubu (Anchieta). 
líquida e sólida provenientes da usina siderúrgica e das usinas de pelotização, bem como de outras unidades industriais instaladas próximas ao município.

$\mathrm{Na}$ análise de Teixeira ${ }^{32}$ (1998), os impactos decorrentes da instalação da atividade siderúrgica no Espírito Santo podem ser organizados em três grupos principais: o primeiro se refere ao comprometimento da base natural/material sobre a qual se assenta a reprodução social no espaço urbano, comprometimento esse causado tanto pela apropriação privada da natureza e do espaço, bem como pela poluição emitida pelas pelotizadoras e pela siderúrgica; o segundo grupo de impacto ambiental se refere ao comprometimento da capacidade de reprodução ampliada da força de trabalho e da qualidade coletiva de vida urbana; o terceiro grupo se refere às pressões econômicas e populacionais, bem como ao comprometimento de importantes reservas naturais, destacando-se os manguezais, as encostas dos morros, a vegetação de restinga e as praias.

$\mathrm{Na}$ medida em que o mercado conduz a uma lógica competitiva que vai privilegiar relações externas comandadas por empresas globais, uma dinâmica praticamente imprevisível se estabelece no próprio lugar em que se exerce essa influência, o que não determina necessariamente uma correspondência com os interesses da sociedade, seja local, seja regional. $\mathrm{Na}$ dinâmica de grandes intervenções que irão configurar novas estruturas espaciais, pode-se afirmar que a questão do território está diretamente vinculada à existência de um Estado como instrumento regulador do sistema de objetos e de ações, conforme argumentam Santos e Silveira:

\footnotetext{
O imperativo de afirmar o Estado sobre a nação e a indispensabilidade de um comando eficaz sobre o território eram argumentos de peso, embora muitos deles fossem exclusivamente ideológicos. Sobre esse pano de fundo, a adaptação ao modelo capitalista internacional torna-se mais requintada, e a respectiva ideologia de racionalidade e modernização a qualquer preço ultrapassa o domínio industrial, impõe-se ao setor público e invade áreas até então não tocadas, como por exemplo, a mídia, o ensino, as relações de trabalho etc.
}

32 TEIXEIRA, Aparecida Netto. Cidade e Siderurgia: A Região Metropolitana de Vitória (ES) e o Complexo Mínero-Siderúrgico. Dissertação de Mestrado. Faculdade de Arquitetura e Urbanismo da Universidade de São Paulo. São Paulo. 1998. 
Considerando que as questões ambientais e culturais são indissociáveis das relações sociais de produção, poderíamos afirmar que a instauração do capital industrial e da solicitação de um espaço compatível com a modernização foi o agente norteador da transformação da configuração socioespacial da atual Região Metropolitana da Grande Vitória. O empreendedorismo hoje presente no planejamento reflete, de certo modo, conforme seja a região ou a cidade, a assimilação maior ou menor das tendências contemporâneas de desregulamentação e redução da presença do Estado na gestão urbana, especialmente considerando o fortalecimento das parcerias público-privado.

\subsubsection{A especialização e a centralidade da RMGV}

O processo de urbanização, historicamente, sempre esteve vinculado ao modo de produção capitalista. O espaço urbano deixa de ser entendido apenas como um produto, dotado de condições materiais e subjetivas, necessárias à produção em geral e à reprodução humana, para se transformar ele próprio em uma mercadoria, por meio das localizações. As localizações surgem no processo de produção do espaço urbano, sendo dadas pelos valores de uso, que são atribuídos ao espaço pelas infraestruturas físicas, as quais fazem com que se materialize a estrutura do espaço.

O Estado, ao promover ações no espaço, a partir da produção de valores de uso, notadamente na criação de infraestrutura, ao mesmo tempo que o torna homogêneo, acaba por diferenciá-lo, ou seja, o espaço, ao ser dotado de condições básicas para sua fluidez de modo a favorecer a circulação de mercadorias, força de trabalho e capital, torna-se desigual (DÉAK, 1985) ${ }^{33}$. Para modelar a nova cidade mínero-industrial, houve grandes investimentos do poder público em infraestrutura (aterros, pontes, etc) que resultou no adensamento da aglomeração de Vitória e a expansão da malha urbana para os municípios vizinhos que hoje constituem a Região Metropolitana

33 DEÁK, Csaba. Rent theory and the price of urban land/ Spatial organization in a capitalist economy. PhD Thesis, Cambridge, 1985 
da Grande Vitória (RMGV) ${ }^{34}$, instituída juridicamente em 1995. A forma como se organizam e se estabelecem os objetos técnicos em um dado território permitiria, assim, explicar as diferenciações regionais.

O conceito de região metropolitana está, em boa parte, ligado ao de centralidade. De maneira geral, uma região metropolitana é estruturada como um sistema polarizado por um núcleo central, no qual se desenvolvem determinadas categorias de atividades, que estabelecem formas de controle sobre as áreas periféricas. A construção hierárquica de uma região envolve necessariamente elementos técnicos de estoque (de recursos humanos, capital, infraestrutura etc.) e de fluxo (de migração de pessoas, informação, conhecimento, financeiro, mercadorias, serviços etc.). A natureza heterogênea do espaço ou território se produz na existência local de um estoque de infraestrutura constituída numa combinação de efeitos de aglomeração e de escala, definindo "lugares" distintos, mas que exercem influência em uma determinada área ou região de seu entorno. O conceito de "centralidade” estabelecido no século XX por Losch (1954) e Christaller (1966), tinha por base essa hierarquia dos espaços e como objetivo estudar a localização e a concentração de atividades empresariais. Assim, as regiões de um determinado território se desenvolvem de forma heterogênea com "sentidos de identidades" e de "hierarquias aglomerativas". Nesse caso, a prevalência do centro urbano da capital sobre seu entorno favorece uma relação de dependência entre a área urbana metropolitana e o interior.

Para Castells (1982), todo o espaço está carregado de significação, mas, além disso, como há uma hierarquia social implícita nessa valorização simbólica, existe também uma hierarquia na valorização espacial. Segundo o autor, "a centralidade urbana será, portanto, também a expressão do nível mais alto dessa hierarquia simbólica“" (CASTELLS,1982,p.66). Nessa perspectiva analítica, o autor identifica quatro elementos na formação da centralidade urbana: divisão social do trabalho; concentração do poder tanto no que diz respeito às atividades econômicas quanto no que diz

34 A Região Metropolitana da Grande Vitória é constituída por 7 (sete) municípios, a saber: Vitória, Vila Velha, Cariacica, Serra, Viana, Guarapari e Fundão com a promulgação da LC no 58 de 1995, o estado do Espírito Santo criou a Região Metro $\neg$ politana da Grande Vitória (RMGV), composta pelos municípios de Cariacica, Serra, Viana, Vila Velha e Vitória, e estabeleceu a base de seu sistema de gestão. Posteriormente, pela LC no 159, de 8 de julho de 1999, foi incluído o município de Guarapari e, em seguida, incorporado o município de Fundão, pela LC nº 204 de 2001. 
respeito ao poder de decisão público e privado; acessibilidade ligada ao crescimento urbano e hierarquização simbólica. Esses fatores permitem extrair os atributos de centralidade econômica, política e simbólica dos centros urbanos.

Falar da Região Metropolitana da Grande Vitória (R.M.G.V) é compreeder a forma como o município de Vitória ${ }^{35}$, capital do estado, exerce influência e atratividade sobre os demais municípios que a integram. Na década de 1980, o desenvolvimento do estado foi predominantemente orientado pela lógica mercantil, com base na indústria, e, preferencialmente, foi localizado no entorno da capital, que, por sua vez, passou a concentrar diversificadas atividades econômicas, com destaque para aquelas ligadas aos setores de comércio, serviços e da construção civil ${ }^{36}$.

A região constituída pela Grande Vitória também passou a subordinar-se, em boa medida, ao desempenho dos novos "centros de poder" ${ }^{37}$ econômico constituídos pelos grandes projetos industriais, devido ao número de atividades que em torno deles giravam. A condição de capital políticoadministrativa do estado, associada às variáveis de intercâmbio com o comércio exterior, explica o dinamismo econômico de Vitória e sua posição de centralidade em relação aos demais municípios que compõem a RMGV (Figura 10). A proximidade física entre os municípios da RMGV e a respectiva característica da conformação e disposição geográfica do aglomerado colocam Vitória como "epicentro" da região, fazendo com que os limites municipais sejam cotidianamente transpostos por seus habitantes

35 Vitória compreende dois territórios distintos, um insular e outro continental numa pequena extensão de $81 \mathrm{~km}^{2}$ e foi alvo de grandes transformações, especialmente por estar limitada à condição de ilha. A ocupação do território é bem antiga (1551) e se deu a partir do setor insular numa região incrustada entre a Baía e a grande escarpa do Maciço (centro histórico), circundada por grandes áreas alagadiças, cujo traçado urbano era tipicamente marcado pela influência portuguesa. A baía de Vitória é um braço de mar que penetra profundamente pelo continente tornando-se um espaço favorável à navegação e ao comércio portuário (figura 9).

36 Apesar de as grandes plantas industriais estarem localizadas nessa microrregião, o setor de comércio e serviços é o mais significativo da economia metropolitana, com destaque para os serviços na área de comércio exterior e distribuição de produtos em larga escala.

37 Segundo Roberto Simões, procurando concretizar a estratégia de crescimento sob a ótica eminentemente privada, os centros de pode: definem políticas públicas próprias; pressionam e/ou interferem na formulação de políticas, nos três níveis de poder ;alavancam e/ou viabilizam reivindicações estaduais, seja do Governo, seja da iniciativa privada, junto ao Governo Federal, as agências de financiamento nacionais e intranacionais e a outras empresas estatais, além de possibilitarem a inclusão do Espírito Santo nas grandes políticas do Governo Federal. (Roberto Simões é professor da Faculdade de Arquitetura e Urbanismo da Universidade Federal do Espírito Santo e assessor técnico do governo estadual). 
e confundidos por seus visitantes. Essa relação de centralidade, tanto geográfica quanto de prestação de serviços, fez com que diversas temáticas urbanas associadas ao espaço, como a logística de transportes, a mobilidade urbana, o controle ambiental das águas e do ar, tivessem suas soluções atreladas de modo irrefutável a um planejamento em escala metropolitana.

$\mathrm{Na}$ medida em que o mercado de trabalho passou a ser organizado em escala que superava em muito os limites municipais da região metropolitana, atingindo uma escala regional, com alta mobilidade no território, a conseqüência lógica foi a acomodação crescente de bairros residenciais e das atividades terciárias nos municípios limítrofes àqueles que compunham até então a RMGV. O poder público (estado e municípios), visando solucionar os problemas gerados pela desenfreada expansão urbana e compa-

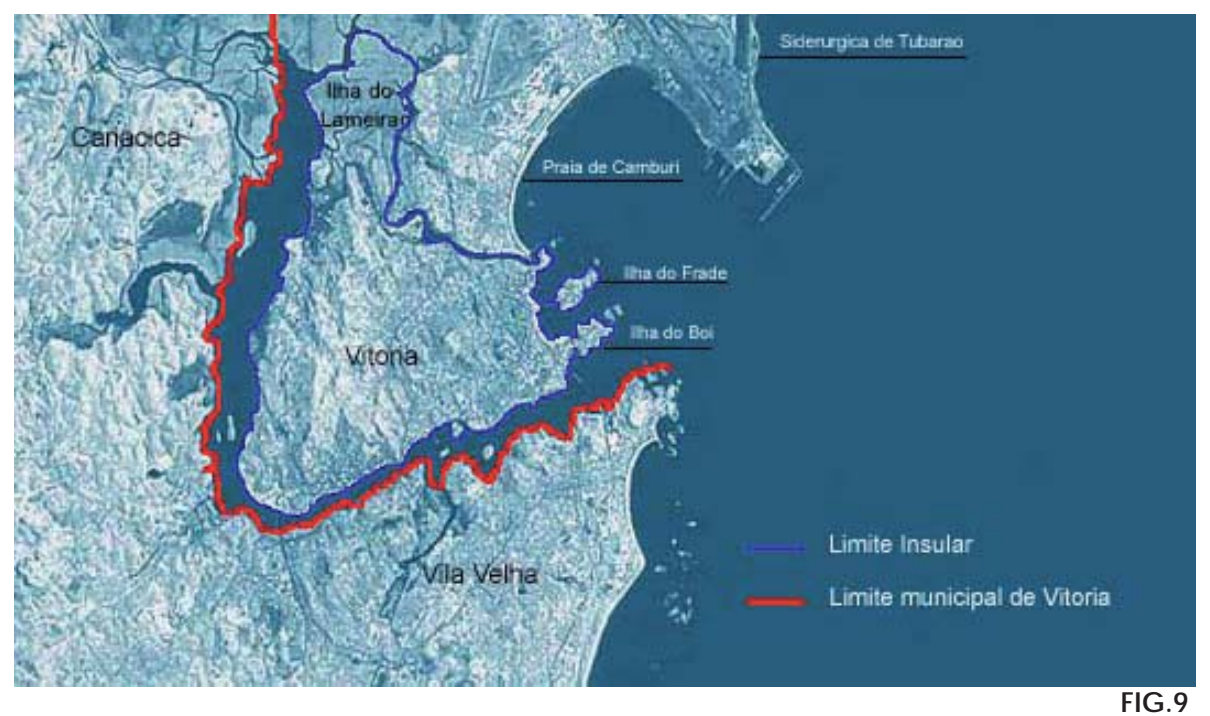

\section{RG.9}

Limites temitoria is do munic ípio de Vitória. A sua condição geográfica coloca-o na posição de centralidade da RMGV. Fonte: Acervo pessoal

RG.10

Região Metropolitana da Grande Vitória mostrando os limites temitoria is dos municípios que a integram: Vitória (centro polític o-a dministra tivo); Serra e Fundão (norte); Cariacica e Viana (noroeste); Vila Velha e Guarapari (sul).Fonte: IJ SN

\section{Tábela 1}

Popula ção dos munic ípios da RMGV, participação no total do Espíito Santo e no total da região - 2008

\begin{tabular}{l|c|c|c}
\hline \multicolumn{1}{c|}{ Estado/ R.M.GV/ Município } & População & $\begin{array}{c}\text { Participação no total do ES } \\
\%\end{array}$ & $\begin{array}{c}\text { Participação no total da } \\
\text { RMGV \% }\end{array}$ \\
\hline Espírito Santo & 3.453 .648 & 100 & --- \\
\hline R.M.G.V & 1.664 .328 & 48,19 & 100 \\
\hline Cariacica & 362.277 & 10,49 & 21,77 \\
\hline Fundão & 16.125 & 0,47 & 0,97 \\
\hline Guarapari & 103.113 & 2,99 & 6,2 \\
\hline Sena & 397.226 & 11,5 & 23,87 \\
\hline Viana & 60.191 & 1,74 & 3,62 \\
\hline Vila Velha & 407.579 & 11,8 & 24,49 \\
\hline Vitória & 317.817 & 9,2 & 19,1 \\
\hline
\end{tabular}




\section{Região Metropolitana da Grande Vitória}

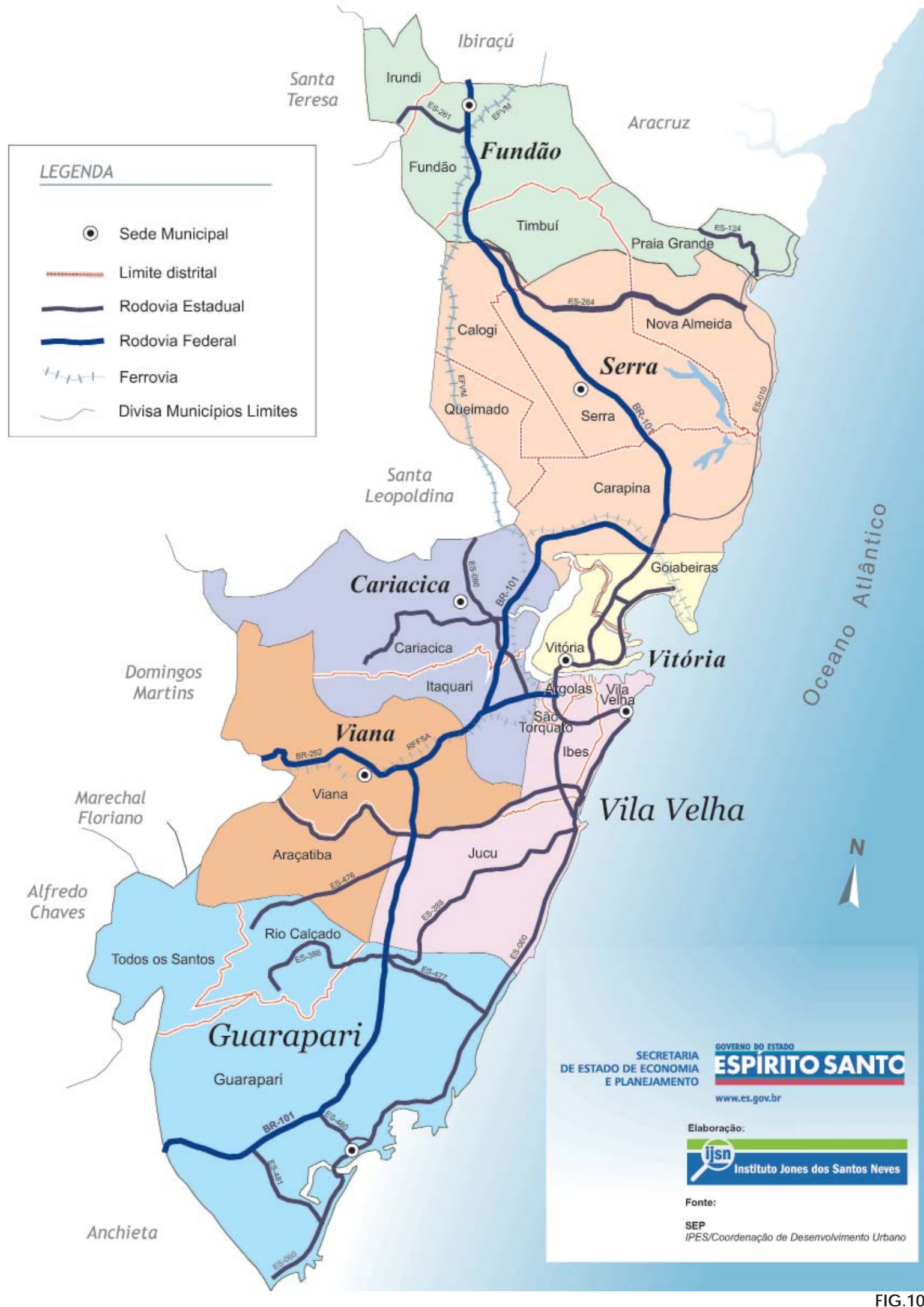




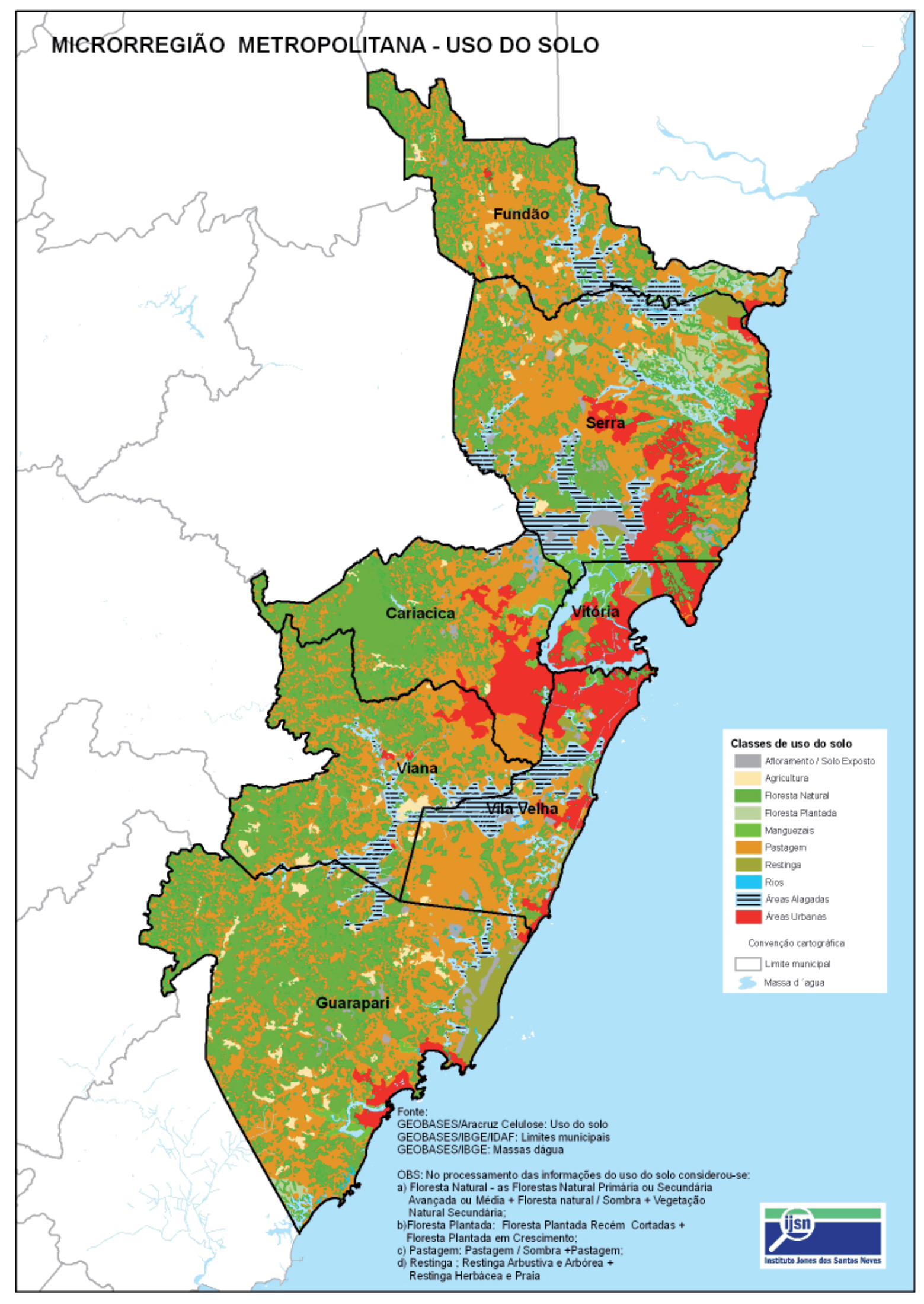

FG.11 
HG.11

Uso do Solo da Região Metropolitana da Grande Vitória. Fonte: Geobases / IJ SN tibilizar território e especialização produtiva, estabeleceu uma política de planejamento urbano que atuasse como um instrumento de ordenação indispensável ao desenvolvimento. Assim, vários planos de estruturação do espaço foram criados. A partir da década de 1980, o Estado se colocou como principal organizador do espaço urbano por meio do seu planejamento estratégico.

As ações do poder público em parceria com o capital privado foram determinantes no processo de metropolização da Grande Vitória. Observa-se que o adensamento das áreas litorâneas do aglomerado urbano foi sendo gradativamente potencializado pelas intervenções sistemáticas no território em função de obras viárias e de infraestrutura, as quais potencializavam os acessos e a mobilidade urbana entre os municípios. Sob a ótica do fator "acessibilidade" como critério essencial para favorecer as práticas metropolitanas, o Estado empenhou-se em promover uma fluidez mais integrativa entre os municípios da RMGV. A construção da Ponte Darcy Castelo Mendonça (Terceira Ponte -1989) pelo governo estadual permitiu a ligação entre os municípios de Vitória e Vila Velha, o que possibilitou uma ocupação mais densa e efetiva do município de Vila Velha.

Outra importante intervenção do Estado foi a implantação do Sistema de Transporte Coletivo da Grande Vitória (TRANSCOL) no final dos anos de 1980, mediante o aporte de recursos por parte do Governo do Estado, que obteve, para tanto, financiamento do Banco Nacional de Desenvolvimento Econômico e Social (BNDES). O programa exerceu papel fundamental na expansão da malha urbana e na diversificação do uso do solo, destacando-se no conjunto das ações estatais de âmbito metropolitano. Esse programa se baseou na integração e implantação de linhas intrarregionais, ampliando e recuperando a malha viária por meio de investimentos diretos, que incluíram a implantação de terminais distribuídos estrategicamente nos municípios metropolitanos. Além de possibilitar a integração de diversas áreas urbanas que apresentavam reduzidas facilidades de acesso, o programa TRANSCOL contribuiu diretamente para intensificar relações intraurbanas que promoveram tanto a expansão quanto a consolidação de diversos subcentros regionais. A evolução gradativa e acelerada do adensamento urbano levou o Governo do Estado a elaborar um novo plano de transportes urbanos para a Grande Vitória, visando re- 
solver o problema da mobilidade, o denominado PDTU GV-2001, o qual propõe a ampliação da rede de linhas troncais e do número de terminais de integração do sistema Transcol.

No âmbito do poder público municipal de Vitória, o planejamento também criou mecanismos de consolidação da malha urbana por meio da flexibilização dos instrumentos de regulação - Planos Diretores -, de forma que a base física estivesse pronta para superar os entraves ao crescimento e dar prosseguimento às atividades de produção, circulação e consumo. Como a consolidação da malha urbana decorre de dinâmicas econômicas e sociais atreladas à diversificada gama de interesses, a participação do setor imobiliário destaca-se por concretizar, por meio de seus empreendimentos, interesses conflitantes no uso e ocupação do solo. Nesse sentido, a atuação imobiliária representa um dos principais geradores de valorização e desvalorização de áreas urbanas - tanto do solo quanto do estoque de edificações -, provocando reestruturações de espaços já consolidados. Emblemática da questão é a reconstrução de alguns bairros tradicionais em outros moldes, ou seja, a substituição de residências unifamiliares por condomínios verticais de alta densidade populacional, o que, frequentemente, deriva para problemas de ordem ambiental e de trânsito local.

Os investimentos privados na Região Metropolitana também redefiniram relações funcionais e mobilidades urbanas por meio da instalação de instituições governamentais e administrativas em áreas de renovação urbana (Enseada do Suá), a partir de aterros sucessivos promovidos pelo estado na região nordeste de Vitória. Ressalta-se ainda a concentração, na RMGV, de equipamentos públicos de saúde e educação, faculdades, serviços de comunicação, rede de hotéis, shopping centers, hipermercados e outros equipamentos de porte regional. A materialidade expressa na estrutura espacial da Região Metropolitana evidencia a valorização em certas áreas em detrimento de outras. Santos (2005, p.264) chama de espaços "luminosos" aqueles que mais acumulam densidades técnicas e informacionais, ficando assim mais aptos a atrair atividades com maior conteúdo em capital, tecnologia e organização. Os subespaços onde tais características estão ausentes seriam os espaços ditos "opacos”.

A situação acima descrita faz crer que investimentos privados e públicos 
Tabela 2

Distribuição da População por Macro e Mic rorregião do Espínto Santo - 1991

\begin{tabular}{|c|c|c|c|c|}
\hline \multirow[t]{2}{*}{ MACRO/MICRORREGIÃO } & \multicolumn{2}{|c|}{ POPULAÇÃO } & \multicolumn{2}{|c|}{ DISTRIBUIÇÃO POR REGIÃO (\%) } \\
\hline & 1991 & 2000 & 1991 & 2000 \\
\hline MACRO SUL & 421.568 & 484.331 & 16,21 & 15,64 \\
\hline Micro Polo Cachoeiro & 283.950 & 331.544 & 10,92 & 10,7 \\
\hline Micro Caparaó & 137.618 & 152.787 & 5,29 & 4,93 \\
\hline MACRO MEIROPOUTANA & 1.635 .281 & 2.016 .720 & 62,88 & 65,11 \\
\hline Mic ro Metropolitana & 1.136 .842 & 1.438 .596 & 43,71 & 46,45 \\
\hline Micro Polo Linhares & 210.428 & 237.291 & 8,09 & 7,66 \\
\hline MicroMetropolitana Expandida Sul & 91.675 & 117.984 & 3,53 & 3,81 \\
\hline Micro Central Serrana & 87.533 & 98.174 & 3,37 & 3,17 \\
\hline Micro Sudoeste Serrana & 108.803 & 124.675 & 4,18 & 4,03 \\
\hline MACRO NOROESTE & 358.415 & 386.981 & 13,78 & 12,49 \\
\hline Micro Polo Colatina & 171.462 & 177.820 & 6,59 & 5,74 \\
\hline Mic ro Noroeste I & 86.806 & 94.858 & 3,34 & 3,06 \\
\hline Micro Noroeste II & 100.147 & 114.303 & 3,85 & 3,69 \\
\hline MACRO NORIE & 185.354 & 209.200 & 7,13 & 6,75 \\
\hline Mic ro Litoral Norte & 134.583 & 158.454 & 5,18 & 5,12 \\
\hline Micro Extremo Norte & 50.771 & 50.746 & 1,95 & 1,64 \\
\hline TOTAL & 2.600 .618 & 3.097 .232 & 100,00 & 100,00 \\
\hline
\end{tabular}

foram direcionados preferencialmente para a região da orla metropolitana, induzidos pela lógica do capital imobiliário, com transferências sucessivas de usos funcionais e implantação de infraestrutura. O espaço denota a seletividade na aplicação de recursos financeiros e técnicos, o que constitui a principal força motriz da desigualdade intra e intermunicipal. De todo modo, a atuação da parceria privada / pública predominou de forma substancial na condução do processo de expansão físico-territorial e de diversificação das atividades econômicas da região metropolitana, estabelecendo, por meio de maciços investimentos, os novos vetores de desenvolvimento que estruturaram a RMGV em moldes essencialmente metropolitanos. 


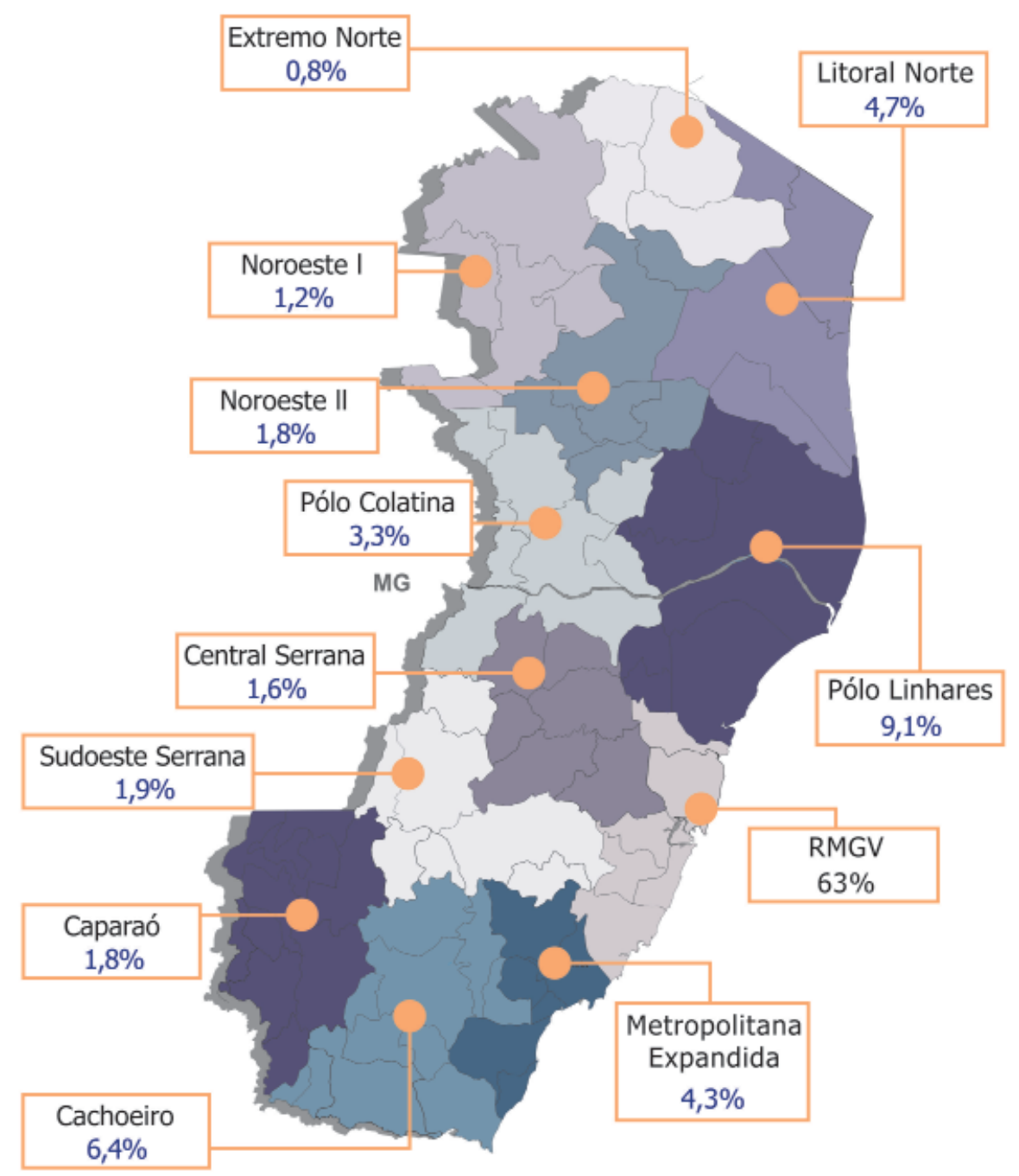

HG.12

Mapa de Distribuição do PIB por mic rorregião. Fonte: Govemo do estado do Espínto Santo - Plano 2025

FG.12

A centralidade assumida pela Região Metropolitana da Grande Vitória, ao longo das três últimas décadas, provocou uma absorção significativa do contingente populacional das outras regiões do estado. $\mathrm{Na}$ década de 1970, o conjunto dos municípios da RMGV já era responsável por 24,1\% da população estadual; na década de 1980 por 34,9\%; e hoje abarca 48\% da população total do estado e concentra 64,4\% do PIB (2004) gerado no Espírito Santo. Essa concentração populacional em um espaço que ocupa um pouco mais de 5\% da área total do estado trouxe, por conseguinte, uma série de problemas característicos de regiões com perfil urbano-industrial.

Partindo para a análise macrorregional, a tabela 2 confirma não apenas a concentração da população na Macrorregião Metropolitana, mas também um aumento considerável do adensamento ao longo das últimas três décadas. No que tange às Microrregiões, verificou-se que somente a Re- 
FG.13

Mapa do Espíito Santo mostrando que a distribuição de renda é desigual. Fonte: IJ SN / I BGE. Censo Demográfic o 2000 FG.14

Mapa do índice de violência do Espínito Santo. Os indicadores mostram que apesar de a pobreza ser maior no norte do estado, a violência está concentrada na RMGV. Fonte: IJ SN / I BGE. Censo Demográfico 2000. gião Metropolitana, Polo Linhares, Metropolitana Expandida Sul e Litoral Norte aumentaram suas participações na composição do PIB do estado. A dinâmica de crescimento e desenvolvimento econômico sempre esteve e permanece concentrada na Região Metropolitana. Os indicadores do PIB, conforme mostra a figura 12, determinam forte concentração da riqueza nas proximidades da Região Metropolitana, enquanto a realidade de grande parte do território capixaba se encontra em situação adversa. Do ponto de vista dos indicadores sociais, sobretudo os indicadores referentes ao interior do estado, especialmente no sentido noroeste e nos municípios limítrofes a Minas Gerais, a situação é mais desfavorável, revelando um perfil de profundas carências em diversos setores. Esses resultados podem ser explicados pela baixa integração entre o primeiro conjunto e o restante da economia e pela fragilidade das finanças estaduais que apresentam margens reduzidas para os investimentos necessários.

Assim, analisado sob o ponto de vista histórico e dos atuais indicadores, poderíamos afirmar que o estado do Espírito Santo teve um processo de

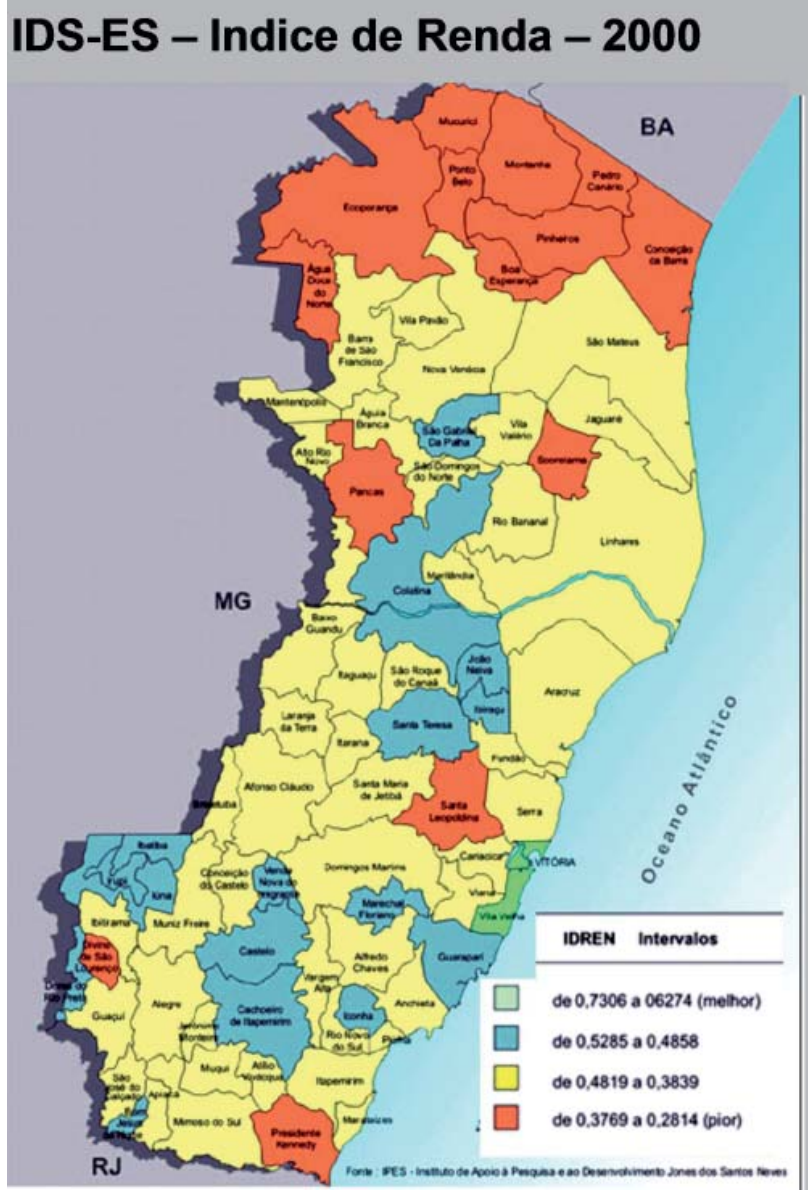

IDS-ES - Indice de Violência - 2000

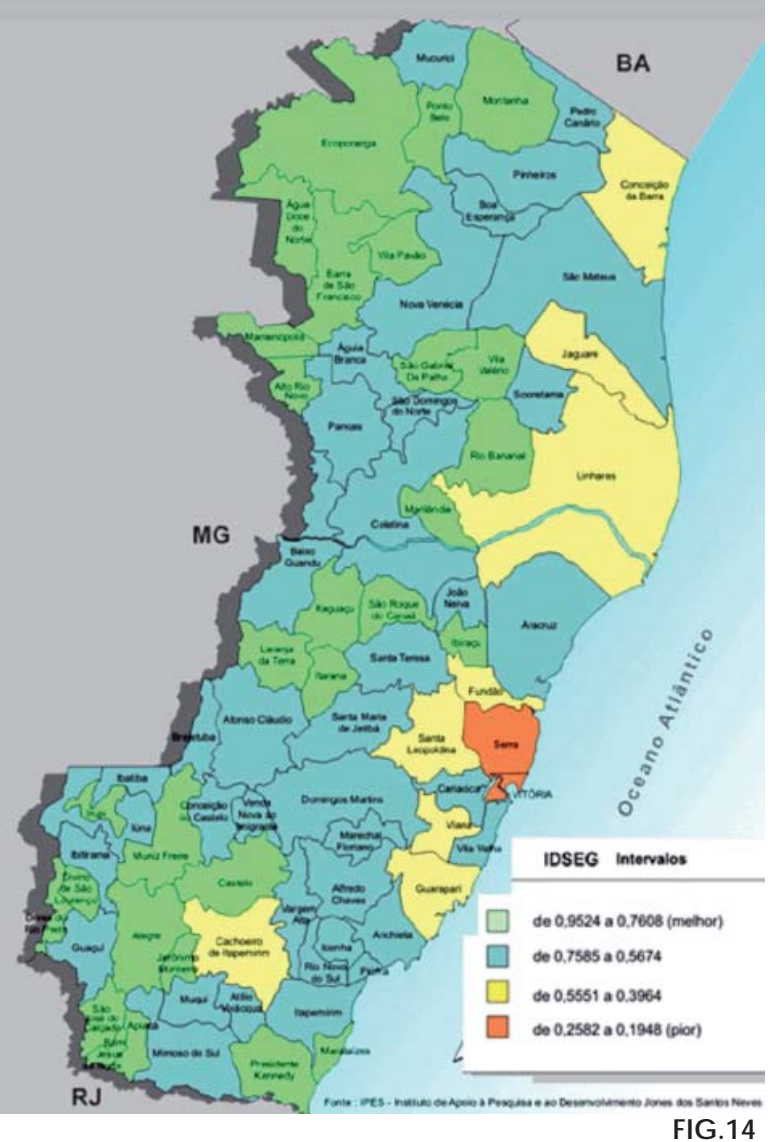




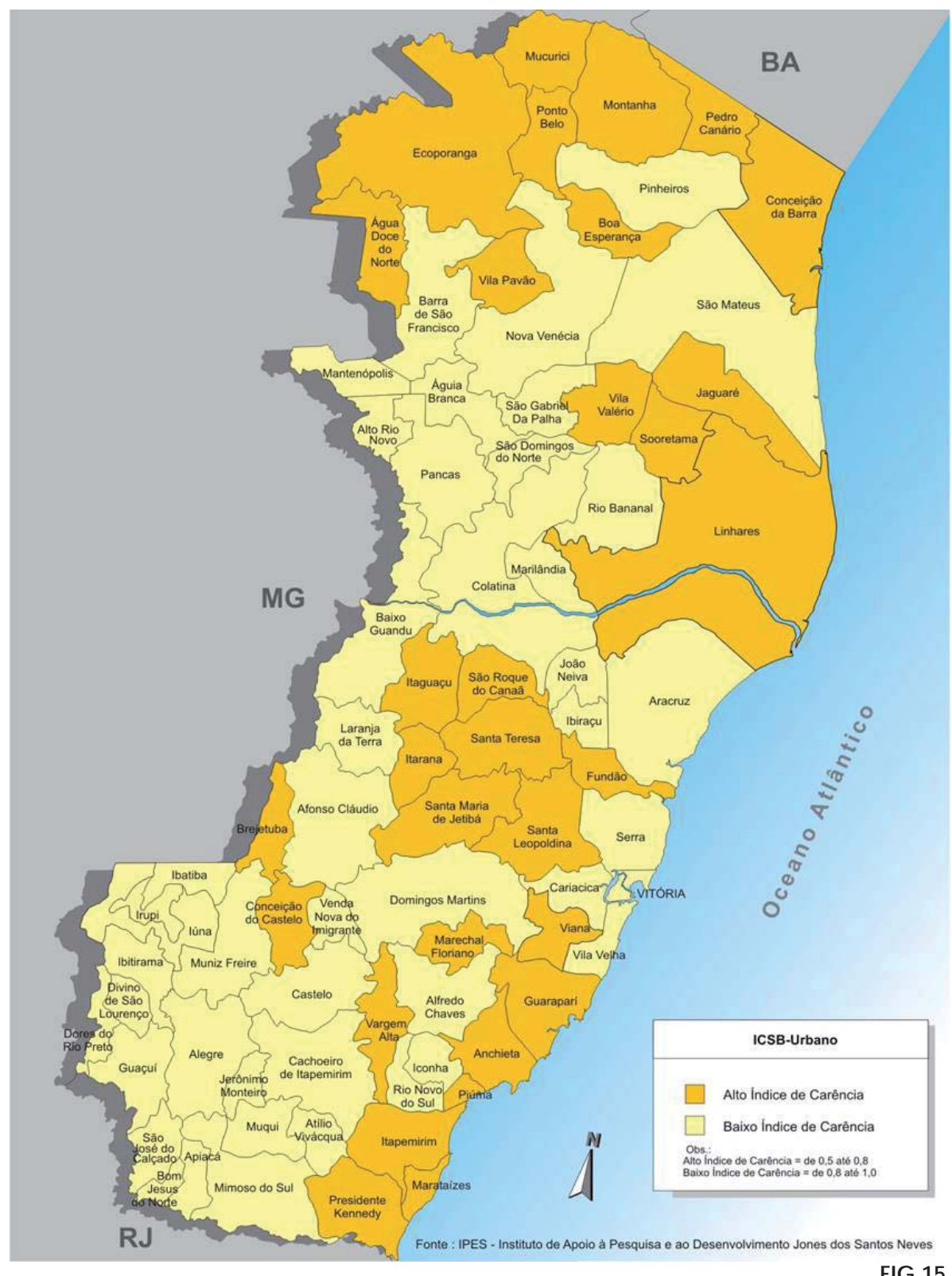

HG.15

Mapa do Saneamento Urbano Espínto Santo. Os maiores índices de carência estão localizados nos municípios do norte do estado, região serrana e no litoral. Fontes: IJ SN / IBGE. Censo Demográfic o 2000

desenvolvimento econômico e social marcadamente excludente. Indicadores econômicos ao lado de baixos índices de escolaridade, de habitação e de infraestrutura urbana, que norteiam o Índice de Desenvolvimento Social (IDS), evidenciam acentuada desigualdade social entre as regiões do estado resultando em crescentes índices de violência (ver indicadores das figuras 13,14 e15). Apesar de a riqueza estar concentrada na Região Metropolitana da Grande Vitória, isto não quer dizer que as regiões mais pobres localizadas ao norte são as mais violentas. A situação ocorre na ordem inversa: verifica-se que os maiores índices de violência se referem aos municípios mais adensados da região metropolitana, como Vitória e Serra. Esses altos índices de violência se mantêm não somente em relação 
ao contexto estadual, mas como também em relação ao contexto nacional. Esse quadro revela que, no estado, o "econômico" e o "social" trilharam rumos diferentes, com uma distribuição desigual dos benefícios gerados pelos ciclos de desenvolvimento.

A urbanização entendida como resultado do processo das relações sociais de produção, portanto, um produto social, ela também se faz desigual de acordo com a concentração do capital produtivo e ocorre de forma diferenciada dependendo das condições socioeconômicas e políticas da região ou do país em que a região esteja inserida. Assim, o espaço geográfico, produzido como espaço relativo, é diferenciado internamente em diferentes escalas, as quais caracterizam o desenvolvimento desigual. Por esse viés analítico, podemos afirmar que o Governo do Estado do Espírito Santo assumiu muitos papéis na configuração socioespacial do território metropolitano, a partir de políticas que respondiam a interesses notadamente econômicos. A produção da "diferenciação/homogeneização" do espaço resultou, definitivamente, no rompimento da estrutura econômico-espacial da Grande Vitória, determinando mudanças qualitativas e estruturais no território, com destaque para a segregação socioespacial.

Conforme mostra o gráfico 1, os grandes investimentos previstos para

\section{Grafico 1}

Investimentos previstos pelo Pla no 2025

Investimentos Previstos por Microrregiões - Em R\$ mil

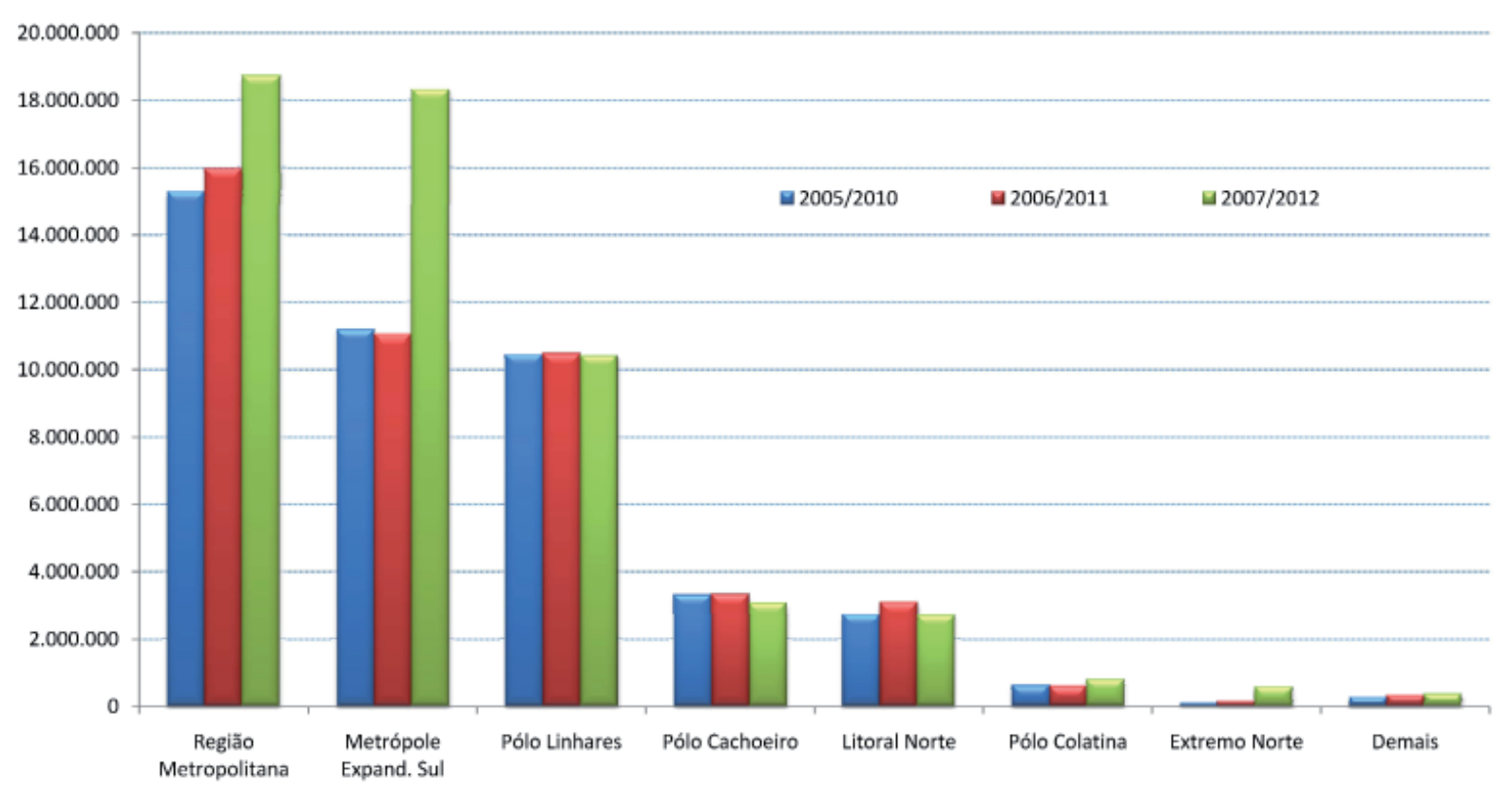


os próximos anos tendem a concentrar-se nas áreas ou nas proximidades onde o meio técnico-informacional é mais denso. Fundamentalmente, a própria concentração do PIB capixaba na Região Metropolitana da Grande Vitória contribui para determinar a atração e a localização de investimentos, o que reflete a concentração das modernizações e parques industriais preferencialmente nessa região. A Região Metropolitana historicamente foi e continua sendo a principal receptora dos investimentos previstos para o estado, com cerca de $\mathrm{R} \$ 18,7$ bilhões no período 20072012, o que representa um crescimento nos investimentos de $17,4 \% \mathrm{em}$ relação ao montante apurado para o período 2006-2011 (IJSN,2008). Essa condição coloca a RMGV num patamar superior em relação às demais regiões quanto à destinação de recursos. Os novos capitais industriais e financeiros apontam para a mesma direção: a Região Metropolitana da Grande Vitória e regiões litorâneas adjacentes. A RMGV tende a continuar ampliando sua rede, tornada mais densa e rápida, chegando a um novo patamar de desigualdades em relação às possibilidades de uso do território.

Com base nos indicadores do governo estadual de investimentos previstos para o período 2007/2012, estima-se que a Região Metropolitana da Grande Vitória fortalecerá, nas próximas décadas, seu papel de principal centro urbano do estado, atraindo investimentos estratégicos capazes de promover o adensamento e a especialização de suas áreas periféricas, reforçando progressivamente a integração intrarregional e a complementaridade das atividades instaladas nos municípios metropolitanos. A integração funcional entre as cidades dos municípios que compõem as regiões litorâneas limítrofes à RMGV faz com que os limites socioeconômicos do complexo urbano não mais coincidam com os limites institucionais. Fluxos de capitais, mercadorias, serviços, pessoas, comunicação e informação se intensificam, gerando fluxos tipicamente intrarregionais.

As informações e os estudos disponíveis concluem que as maiores cidades - em especial as metrópoles - provocam índices mais elevados de produtividade e maior renda per capita nos territórios em que estão inseridas, detendo uma participação decisiva na contabilidade dos seus respectivos estados e/ou unidades territoriais. Historicamente, as políticas governamentais sempre deram maior atenção aos arranjos metropolitanos, o que pode ser comprovado pela revisão do percurso histórico das regiões me- 
tropolitanas brasileiras sob a ótica dos recursos públicos aplicados. Em 2005, após 10 anos de existência da Região Metropolitana da Grande Vitória, o estado criou um sistema gestor composto por um Conselho Metropolitano (Comdevit) e o Fundo Metropolitano (Fumdevit), cujo objetivo é construir diagnósticos temáticos e identificar projetos prioritários de interesse metropolitano. A estratégia inicial formulada pelo Comdevit e alinhada ao Plano de Desenvolvimento do Espírito Santo - ES 2025 foi estruturar o sistema de informações metropolitanas e, a partir dele, uma carteira de projetos detalhada em Projetos Executivos temáticos. Entretanto, há problemas na convergência de ideias e projetos, e mesmo disputas de poder político que atravancam o "pensar" metropolitano.

A centralidade com base na hierarquia dos espaços está vinculada a determinadas formas de poder, especialmente o econômico. Por outro lado, as escolhas que o planejamento técnico faz e implanta no território não podem ser explicadas apenas por uma lógica estritamente econômica ou tecnológica, como afirma o discurso neoliberal. As técnicas, em todos os seus níveis, exigem legitimação para se implantarem. Essa legitimação, em geral, reflete o interesse de grupos sociais específicos (grandes empreendedores privados, por exemplo) que, frequentemente, são respaldados pela ação política em um contexto mais amplo, das redes técnicas. Estas, vale dizer, pouco familiares aos lugares nos quais se concretizam.

A experiência do processo de industrialização no Espírito Santo, numa primeira etapa, mostrou antagonismos socioambientais, e as desigualdades regionais tornaram-se evidentes. A decisão geopolítica de estimular e concentrar a industrialização na RMGV teve influência relevante nesse processo, assim como o Estado teve aí papel fundamental, viabilizando as infraestruturas e os marcos jurídicos regulatórios. Assim é que, historicamente, ocorre o aparelhamento do território do Espírito Santo: do planejamento estratégico do Estado à maximização de uso para as empresas, sem que haja contrapartidas efetivamente favoráveis ao equilíbrio das diversas dimensões inerentes aos lugares dos quais se faça uso. Excelentes indicadores econômicos ao lado de baixos índices de desenvolvimento humano marcaram o primeiro ciclo de industrialização no estado.

Para Souza (2006), o resgate do papel do Estado implica planejamento e/ 
ou gestão, e nesse sentido, implica envolvimento com o território. O termo "gestão" do território se apresenta, de forma recorrente, como expressão que sucede a do "planejamento", largamente desacreditado e associado a práticas autoritárias do Estado desenvolvimentista. A transformação do Estado não pode ocorrer por uma ruptura brusca, tendo em vista as condições de um passado que ainda se faz presente. O que cabe observar, de toda maneira, é que a presunção da palavra gestão em aparecer como uma alternativa mais moderna nos convida a levar a sério a necessidade de ter clareza quanto aos fins da ação ou intervenção proposta. A experiência nacional mostra que os lugares que contêm tecnologia e riqueza tenderão a ser geridos pelo poder empresarial em experiências de desenvolvimento. Apesar da história do planejamento mostrar descompasso entre prioridades técnicas e sociais, a gestão pública deve ser entendida como prática científico-tecnológica que envolve a negociação com todos os atores participantes do processo de desenvolvimento e emerge como alternativa para o planejamento estratégico no momento em que se retoma a democracia no país, operando com base em acordos e consensos. 


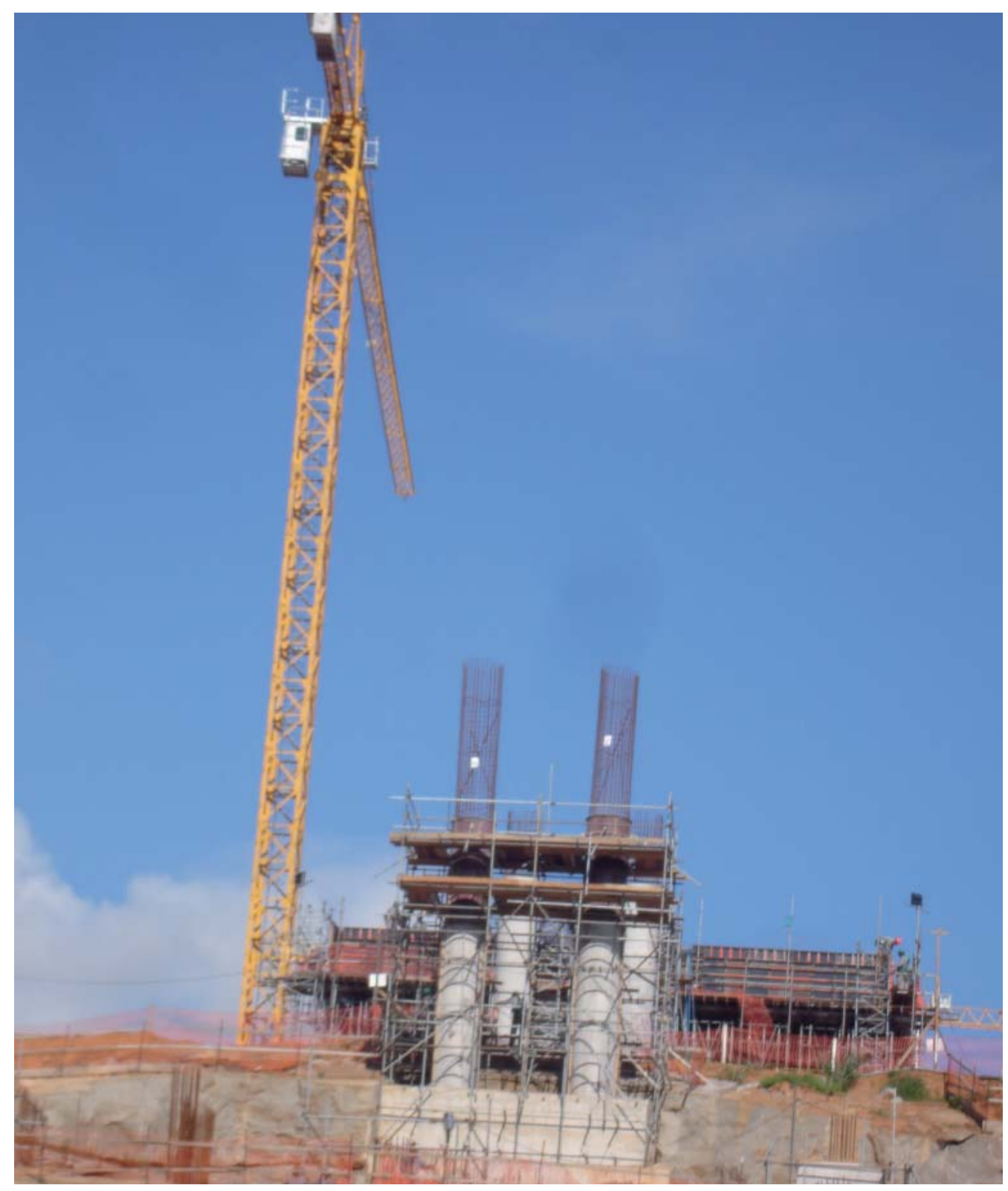

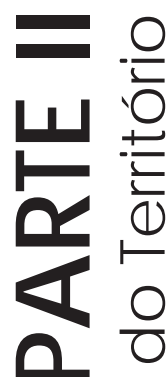

${ }_{2} 0$

un

¿

$\sigma$

으

(1)

(1)

$\frac{1}{2}$
$\frac{2}{0}$
$\frac{0}{0}$
$\frac{0}{0}$

0

$2 \sqrt{0}$

un

N

家

$\cup$

(1)

บิ

O objeto - a coisa - sempre me fascinou e de algum modo me destruiu [...] Coisa é bicho especializado e imobilizado[...] é uma aproximação tímida minha da subversão do mundo vivo e do mundo morto ameaçador.

Clarice Lispector (1949) 


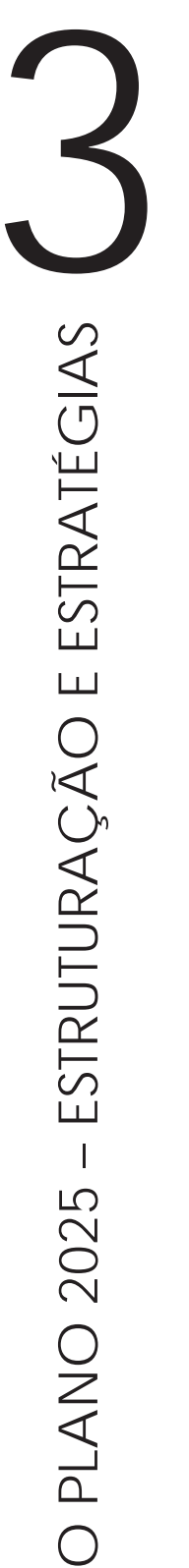

O "empresarialismo" reflete a tendência contemporânea de desregulamentação e diminuição da presença do Estado no terreno do planejamento e da gestão urbana, sugerida pela fórmula "parcerias público-privado". E pelo menos, nas situações mais nitidamente empresarialistas, conforme sugere Harvey (2000), "the public-private partnership means that the public takes the risks and the private takes the benefits"

Souza (2006, p.137) 
104| CAṔ́tULO 3 


\section{O PLANO 2025 - ESTRUTURAÇÃO E ESTRATÉGIAS}

Marx e Engels (1987), afirmam que, para se entender como a história se movimenta temos que entender como as sociedades se organizam economicamente, como os modelos econômicos se sustentam e como eles declinam. Dessa forma, devemos conhecer a estrutura da sociedade, ou seja, sua base material ou econômica deve ser entendida como o somatório de forças produtivas (que são as ferramentas, as máquinas, as técnicas e tudo mais que permite a produção) e as relações de produção (relações entre os que são proprietários dos meios de produção, as terras, as matériasprimas, as máquinas - e aqueles que possuem apenas a força de trabalho). A infraestrutura, por sua vez, determina diretamente a superestrutura, constituída pelas instituições jurídicas (leis e organização do judiciário), políticas (formas de organização e papel do executivo e do legislativo) e ideológicas (as artes, a religião, a moral) de uma época. Na visão marxista, as relações entre o espaço e as práticas políticas são "entendidas como as ações sociais que têm por finalidade a conquista ou detenção do poder"“ resultantes das relações de dominação que se estabelecem entre o Estado e as classes sociais pela propriedade do espaço físico, e que se "justifica mediante formulações de caráter ideológico e legitima-se no ordenamento jurídico"(LEFEBVRE, 1986) .

Considerando a evolução histórica do território do Espírito Santo, podemos afirmar que o Estado esteve notadamente submetido às forças que operam no âmbito das macropolíticas federais com intervenções urbanas marcadas, sobretudo, pela legitimação da hegemonia política e das grandes empresas multinacionais. Dada a forma como a conjuntura econômica se instalou no território, conforme vimos no capítulo anterior, a realidade mostra que há uma profunda dualidade na distribuição da riqueza no estado: de um lado, um conjunto de atividades ligadas à siderurgia, à celulose e aos fluxos de comércio com o exterior, que operam com altas escalas de valores e amplamente concentradas no entorno e na Região Metropolitana; de outro lado, um conjunto formado pelas atividades desenvolvidas nos diversos setores por pequenas e médias unidades produtivas distribuídas no restante do território. 


\section{Tabela 3}

Distribuição PIB por mic roregião

\begin{tabular}{l|c}
\multicolumn{1}{c|}{ Mic rorregião } & Distribuição PIB \% \\
\hline RMGV & 63,1 \\
\hline Pólo Linhares & 9,1 \\
\hline Cachoeiro & 6,4 \\
\hline Litoral Norte & 4,7 \\
\hline Metropolitana Expandida Sul & 4,3 \\
\hline Pólo Colatina & 3,3 \\
\hline Sudoeste Serrana & 1,9 \\
\hline Noroeste II & 1,8 \\
\hline Caparaó & 1,8 \\
\hline Central Serrana & 1,6 \\
\hline Noroeste I & 1,2 \\
\hline Extremo Norte & 0,8 \\
\hline Fonte: & \\
\hline
\end{tabular}

Fonte: IJ SN relativos a o a no 2005

Importante ressaltar que, se, por um lado, a implantação dos Grandes Projetos no Espírito Santo proporcionou uma significativa elevação no volume e no valor da produção industrial no estado, ampliando a oferta de emprego no setor secundário e, por essa via, influenciando na circulação de renda da economia capixaba, por outro lado, provocou profundas alterações na estrutura urbana, social e ambiental do Espírito Santo. As taxas de crescimento quanto à composição do PIB por setores de atividade propõem uma interpretação positiva do desempenho da economia no que diz respeito ao avanço do grau de desenvolvimento econômico do Espírito Santo. Entretanto, esses indicadores não se distribuem de forma equilibrada no território estadual, mas estão concentrados na Região Metropolitana, que alcança o patamar de $63,1 \%$ do PIB total do estado ${ }^{38}$. Essa concentração extremamente pontual das modernizações inseridas no território revela, a um só tempo, o grau de intencionalidade das escolhas dos lugares e dos agentes aptos a fazer uso delas.

Com fins a reverter esse quadro de grandes desigualdades regionais, conforme mostra a tabela 3, e de ter como perspectiva uma "visão de futuro" coerente com as metas propostas na campanha do atual governador Paulo Hartung, o Governo do Estado do Espírito Santo lançou, no ano de 2006, o seu planejamento estratégico de longo prazo: o Plano 2025. Há, na 
contemporaneidade, uma tendência ao resgate da política desenvolvimentista apoiada em polos de desenvolvimento, porém, em outros moldes, articulados às redes globais. O Plano 2025 dá ênfase à descentralização da economia, com a criação de novos pólos econômicos industriais e redes de cidades, dentre eles, o Polo Industrial de Anchieta.

O Plano 2025 está sendo encarado pelo governo como a construção de um novo modelo, cujo discurso se baseia na lógica de integração às redes globais e geração de riqueza. Os projetos são, ainda, complementados por uma agenda de comunicação. Em seu escopo, o Plano estabelece uma previsão de investimentos que orienta simultaneamente diversas estratégias para o alcance de um "cenário futuro desejado" e tem, por discurso, a integração econômica entre as regiões do estado. A visão de futuro contém, ainda, um plano de metas para o horizonte 2005-2025, marco referencial para construção de uma agenda de planejamento estratégico ${ }^{39}$.

O Governo do Estado, ao conceber o Plano 2025, apostou no impacto positivo da pauta exportadora capixaba (em volume e preços), no período 2000/2005, em decorrência do aumento da demanda externa por alimentos, commodities industriais, energia e matérias-primas. Por outro lado, o fortalecimento de polos de importação e exportação do Pacífico ou Atlântico Norte/Sul foi um dos fatores externos impactantes que demandou e exigiu do sistema capixaba maior fluidez nas operações logísticas, de modo que o estado do Espírito Santo pudesse estar apto a se inserir na disputa pelo ganho do mercado global.

Estudos econômicos ${ }^{40}$ (Tabela 4) também apontavam na mesma direção:

39 GOVERNO DO ESTADO DO ESPÍRITO SANTO. SECRETARIA DE ESTADO DE ECONOMIA E PLANEJAMENTO. Espírito Santo 2025: Plano de Desenvolvimento. Vitória. 2006

40 A trajetória da carteira de investimentos anunciados para o estado no período entre 2000 e 2004 apontava uma evolução ascendente de valores, indicador este que revelava potencial agregador na capacidade de produção. Entre 2000 e 2002, o crescimento dos investimentos, a preços correntes, foi da ordem de $\mathrm{R} \$ 6,4$ bilhões, ou de $\mathrm{R} \$ 2,1$ bilhões em média anual. Na fase seguinte, entre 2003 e 2004, a evolução da carteira foi ainda maior: R\$10,2 bilhões. É importante ressaltar que, em 2004, novas fontes de informação foram inseridas na coleta de dados, o que permitiu agregar novos investimentos. Entre 2005 e 2007, período em que se consolidou o aprimoramento das fontes de informação, foram adicionados R $\$ 11,3$ bilhões à carteira, o que evidencia capacidade de atração de novos investimentos numa média de $\mathrm{R} \$ 3,8$ bilhões/ano. Observa-se o substancial aumento dos investimentos previstos para a indústria e, em menor escala, para terminal portuário e aeroportuário, o que revela uma tendência de crescimento convergente com o potencial industrial e a vocação logística do estado. Fonte: GOVERNO DO ESTADO DO ESPÍRITO SANTO. SECRETARIA 


\section{Tabela 4}

Evolução, número de projetos, do valor total e do valor unitánio

\begin{tabular}{c|c|c|c} 
Ano & No de projetos & Valortotal & Valor médio \\
\hline $\mathbf{2 0 0 0}$ & 195 & 13.437 & 144,48 \\
\hline $\mathbf{2 0 0 1}$ & 230 & 17.790 & 77,35 \\
\hline $\mathbf{2 0 0 2}$ & 256 & 19.787 & 77,29 \\
\hline $\mathbf{2 0 0 3}$ & 350 & 25.530 & 72,94 \\
\hline $\mathbf{2 0 0 4}$ & 403 & 35.775 & 88,77 \\
\hline $\mathbf{2 0 0 5}$ & 491 & 44.133 & 89,88 \\
\hline $\mathbf{2 0 0 6}$ & 521 & 45.298 & 86,94 \\
\hline $\mathbf{2 0 0 7}$ & 631 & 55.438 & 87,86
\end{tabular}

Fonte: Geres / Bandes, Invest ES,SEAMA/IEMA.

Ela boração: IJ SN- Investimentos 2007-2012-a no2008

o cenário mundial, tal como se apresentava no início do século XXI, era favorável ao crescimento do estado, tanto pelas expectativas geradas em torno da economia mundial, como também pela expansão da demanda interna em função do aumento da capacidade produtiva. Sob esta ótica e aproveitando as vantagens logísticas e portuárias do estado do Espírito Santo, o Governo do Estado priorizou a construção de um plano de longo prazo que concentrasse esforços na direção de um ambiente propício aos investimentos em todos os segmentos da economia capixaba, principalmente naqueles considerados estratégicos para consolidar o desenvolvimento do Espírito Santo, como o comércio exterior.

Além do cenário mundial favorável ao crescimento das exportações no Espírito Santo, um fator fundamental que pesou na tomada de decisões para a estruturação do Plano 2025 era a necessidade de resgatar a imagem do Governo do Estado, ante a grave crise ética e institucional marcada por um quadro de corrupção generalizada, que havia caracterizado os últimos mandatos de governo do Espírito Santo. A sociedade demandava uma atitude coerente e de seriedade do governo para dar credibilidade e respaldo às metas anunciadas e vislumbrar um futuro promissor. Assim, para que se possa compreender a criação do Polo Industrial de Anchieta, objeto empírico desta tese, é necessário compreender a concepção ideológica do Plano 2025, cujas diretrizes mestras definem e estabelecem as bases que

DE ESTADO DA ECONOMIA E PLANEJAMENTO. Instituto Jones dos Santos Neves. Investimentos Previstos 2007-2012. Vitória. 2008. 
deram sustentação à construção do Polo.

\subsection{Diretrizes de desenvolvimento}

Ao se reeleger, em 2006, a liderança do governador Paulo Hartung ${ }^{41}$ foi decisiva para viabilizar projeto de tal envergadura. O governador recebeu de seu antecessor um estado sem crédito junto aos órgãos financeiros federais e mundiais, seriamente endividado, com graves problemas na máquina administrativa e sem capacidade para os investimentos necessários nas áreas sociais e na estrutura física. O discurso de Paulo Hartung, por ocasião do lançamento do Plano 2025, expressava a intenção de mudança na eficiência do setor público e a de aceleração da economia em outras bases:

O Espírito Santo avança, nestes últimos anos, no processo de constituição de uma nova era histórica. Conquistada a estabilidade político-institucional, iniciamos o terceiro ciclo econômico, com a expansão, modernização e qualificação do agronegócio e da indústria exportadora, além da efetivação do negócio do petróleo e gás.

Mas a novidade não está apenas nos fatores político-econômicos. Este momento também é inédito pelo novo modelo de desenvolvimento que estamos implementando no Estado. Estamos trabalhando por um processo de desenvolvimento econômico geograficamente desconcentrado, socialmente justo e inclusivo e ambientalmente sustentável. Nesse sentido, a Agenda 21 Anchieta é um passo que se soma a essa caminhada.

Nesse sentido, o horizonte parece ser bem promissor, como bem indica a própria realização deste Plano Estratégico 2025, resultado de um esforço de parcerias. Para finalizar, gostaria de destacar que este Plano é também uma mostra do amadurecimento e da modernização da gestão pública, uma vez que resulta da intensa utilização do planejamento estratégico em terras capixabas.

Paulo Hartung (2006)

O Plano ES 2025 apresenta uma carteira de 93 Projetos Estruturantes em

41 O governador Paulo Hartung (2006-2010-PMDB) está realizando seu segundo mandato. O primeiro foi 2002-2006, sendo reeleito nas eleições para 2006. O governador ao se reeleger, segundo pesquisas, obteve uma aprovação pela população de $77 \%$. 
quatro alianças estratégicas reunidas em 11 grupos, a saber ${ }^{42}$ :

1. Desenvolvimento do capital humano.

2. Erradicação da pobreza e redução das desigualdades.

3. Redução da violência e da criminalidade.

4. Interiorização do desenvolvimento.

5. Desenvolvimento da rede de cidades.

6. Recuperação e conservação de recursos naturais.

7. Agregação de valor à produção, adensamento das cadeias produtivas e diversificação econômica.

8. Desenvolvimento da logística.

9. Capital social e qualidade das instituições capixabas.

10. Fortalecimento da identidade e melhoria da imagem capixaba.

11. Inserção estratégica regional.

Cada uma das onze estratégias de desenvolvimento foi traduzida em um grupo de projetos estruturantes, num total de 93, que são os instrumentos escolhidos para operacionalizar as estratégias de ação. Na concepção geral do Plano, o agrupamento de projetos tem por finalidade proporcionar uma "soma sinérgica dos resultados de cada projeto estruturante" de modo a ampliar a capacidade de transformação da realidade. A princípio, os projetos não seriam implementados simultaneamente, mas em conformidade com as prioridades estabelecidas pelo planejamento tático, obedecendo a uma dinâmica de longo do tempo em função da execução dos resultados e da evolução dos fatores externos. Cada grupo de projeto possui pelo menos um projeto âncora, que é aquele que contribui para a superação do gargalo negativo existente e/ou assegura a integração do conjunto, conforme imagem de futuro prevista no Plano 2025:

Imagem do futuro/conhecimento das oportunidades:

- Consolidação do papel exportador

- Exploração do petróleo

- Qualidade de vida alta: IDH

42 GOVERNO DO ESTADO DO ESPÍRITO SANTO. SECRETARIA DE ESTADO DE ECONOMIA E PLANEJAMENTO. Espírito Santo 2025: Plano de Desenvolvimento. Vitória. ES. 
- Consciência política

- Melhoria ambiental.

Fragilidades ou gargalos dessa imagem do futuro:

- Dependência das commodities (ferro, aço e minérios)

- Dependência de poucas e grandes empresas

- Violência e insegurança

- Distribuição desigual de renda

- Degradação da infraestrutura.

Na concepção do Plano 2025, os principais desafios do Espírito Santo para os próximos 20 anos, na órbita econômica, consistem em empreender a “atração agressiva de novos investimentos; conquistar uma transformação radical da qualidade de seu capital humano; ampliar sua capacidade de inovação tecnológica, de modo coerente com a evolução da economia do conhecimento que se desenha em escala mundial" (ESPÍRITO SANTO 2025, 2006, p.118). Para viabilizar a execução dos 93 projetos estruturantes, estimou-se a necessidade de aplicação de R $\$$ 68,8 bilhões, em 20 anos, distribuídos ao longo do período de planejamento. Os recursos financeiros serão oriundos de: recursos privados ou empresas estatais $(51,1 \%)$; recursos públicos federais (19,7\%); recursos públicos estaduais $(17,7 \%)$; recursos públicos municipais $(11,3 \%)$; Doações internacionais $(0,1 \%) .{ }^{43}$

No escopo geral dos onze grupos que formam a carteira de projetos, destaco três estratégias que estariam mais diretamente relacionadas com o objeto da tese, as quais serão tratadas com mais detalhe: Desenvolvimento da Rede de Cidades; Desenvolvimento da Logística; Imagem e Comunicação do Plano.

\subsubsection{Desenvolvimento da rede de cidades}

O Plano 2025 contempla como metas estabelecer uma rede de cidades mais "equilibrada e que alcance o Índice de Primazia" de 0,6 até 2025 e

43 SECRETARIA DE ESTADO DE ECONOMIA E PLANEJAMENTO. Espírito Santo 2025. Plano de Desenvolvimento. Vitória. 2006.

44 O Índice de Primazia é da ordem de 0,77 com base no Censo de 2000. 
ampliar a qualidade de vida no ambiente urbano”. Desse modo, o objetivo maior é "prover a Rede de Cidades do Espírito Santo de instrumentos de planejamento e gestão que façam frente aos desafios de crescimento, sustentabilidade e qualidade do espaço urbano" (ESPÍRITO SANTO 2025, 2006) A estratégia está direcionada para o ordenamento territorial e gestão de cidades, com respectivos instrumentos de regulação. O projeto privilegia sistemas de integração que possam proporcionar melhorias das condições logísticas de escoamento de produção e que favoreçam as interconexões regionais. As cidades e/ou regiões indicadas como pólos centralizadores e integradores estão relacionadas ao projeto de $\mathrm{n}^{\circ} 36$, a saber:

Projeto 36 - Planejamento e Gestão de Cidades:

- Desenvolvimento da Região Metropolitana da Grande Vitória

- Rede de Cidades Cachoeiro de Itapemirim

- Rede de Cidades Colatina

- Rede de Cidades Linhares

- Rede de Cidades São Mateus

- Rede de Cidades Nova Venécia

- Desenvolvimento Urbano de Aracruz e Região de Impacto

- Desenvolvimento Urbano de Anchieta e Região de Impacto

- Rede de Cidades Serranas

- Rede de Cidades Caparaó

- Expansão com Qualidade da Habitação Urbana

O planejamento estratégico do Estado, cujo comando também se realiza pelas demandas de grandes multinacionais no uso do território, tende a implementar um rearranjo do processo de metropolização que deverá estender-se para microrregiões litorâneas imediatamente próximas à RMGV. Já é possível observar uma tendência ao adensamento urbano-industrial nessas regiões, devido não somente às plantas industriais já existentes nos municípios de Anchieta e de Aracruz - SAMARCO e ARACRUZ CELULOSE, respectivamente -, mas como também, aos investimentos futuros previstos no Plano 2025, tanto na expansão dessas instalações, quanto no surgimento de novas atividades, como, mais uma vez, o caso da indústria siderúrgica e petrolífera. O movimento claramente observado dos investimentos nas duas regiões litorâneas que fazem fronteira com a RMGV, 
indica a possibilidade futura de conurbação entre elas, ampliando-se e estendendo-se o que seria hoje a RMGV.

Interessante observar que no grupo de cidades referenciadas no projeto "Rede de Cidades", o Plano 2025, já pressupondo impactos advindos das atividades industriais, faz menção destacada às regiões que hoje já desenvolvem projetos industriais e estão atreladas às redes globais e à logística portuária, como se vê a seguir: "Desenvolvimento da R.M.G.V"; "Desenvolvimento Urbano de Anchieta e Região de Impacto"; "Desenvolvimento Urbano de Aracruz e Região de Impacto". As outras cidades são referenciadas apenas como fazendo parte do grupo que integra a "Rede de Cidades". Esta situação indica ou pressupõe formas de condução diferenciadas no planejamento das ações, ou seja, o Estado define as regiões que deverão receber maior densidade de tecnologias e empreendimentos. Ao atrelar o desenvolvimento da região a possíveis impactos a serem gerados, o Estado já prevê os conflitos que poderão advir do planejamento.

Uma forma de inferir a tendência de expansão econômica de algumas regiões é comparar a participação relativa delas no total da carteira de investimentos no período 2007-2012 (Tabela 5). O percentual de recursos destinados a cada uma das regiões indica uma tentativa de redistribuição da riqueza para determinadas regiões, embora o grande montante ainda se concentre nas proximidades da RMGV. Em face aos recursos destinados às microrregiões, é possível identificar aquelas regiões que tendem a se expandir nos próximos anos: a Microrregião Metrópole Expandida Sul ${ }^{45}$ (lócus do Polo Anchieta), com investimentos previstos no valor de R \$ 18,3 bilhões, seguido pela Microrregião Polo Linhares, com investimentos da ordem de $\mathrm{R} \$ 10,4$ bilhões, com destaque para as atividades relacionadas à prospecção e extração de petróleo (Figuras 17 e 18).

Ambos os municípios - Anchieta e Linhares - aumentaram substancialmente sua participação relativa no total dos investimentos do estado e formam hoje, junto com a Região Metropolitana, os polos mais importantes de atração de investimentos do estado. O primeiro está associado

45 A Metrópole Expandida Sul abrange os municípios de Alfredo Chaves, Anchieta, Iconha, Itapemirim, Píuma e Marataízes. 


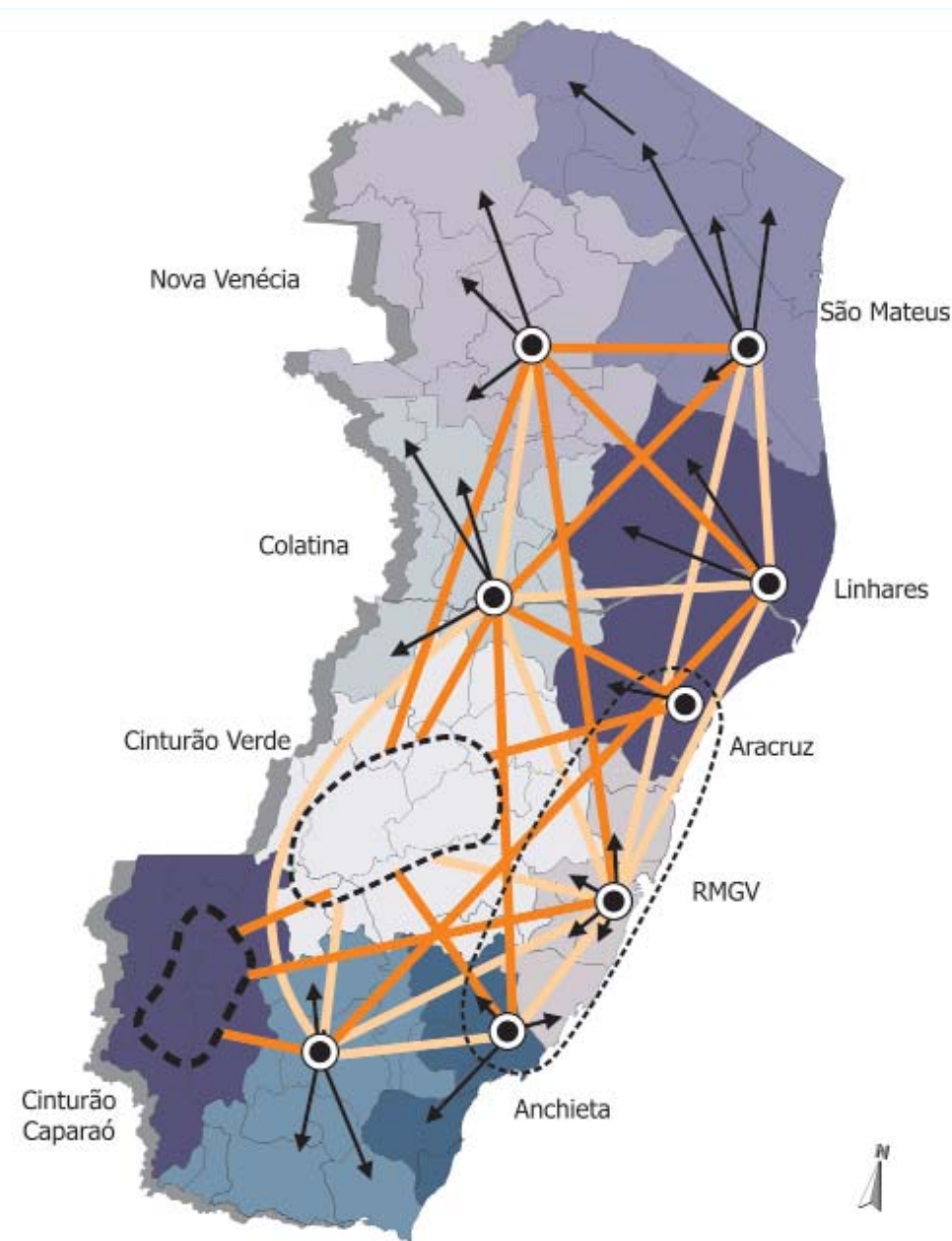

HG.16

Rede de cidades contempladasno Plano 2025.

Fonte: Govemo do Estado do Espíito Santo. Espírito Santo 2025. Plano de Desenvolvimento

\section{Legenda}

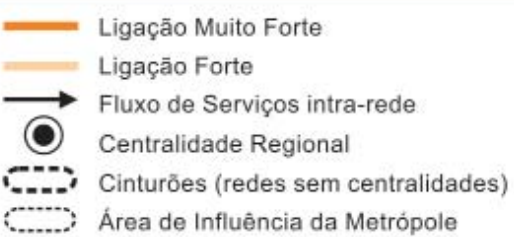

FG.16

aos projetos que integram o Polo Anchieta ${ }^{46}$, estando o Polo Linhares diretamente relacionado às atividades de prospecção e extração de petróleo $(37,8 \%)$ e fabricação de outros equipamentos de transportes, além da fabricação de celulose (12,4 \% do total). O Polo Linhares contempla a fábrica da Aracruz Celulose, que movimenta grandes vultos de capital. Com percentagem bem menor na participação dos investimentos, está o Polo Cachoeiro, com 5,5\% o qual tem no beneficiamento das rochas ornamentais uma das principais fontes de arrecadação (IJSN, 2008). A integração funcional entre as cidades dos municípios que compõem essas regiões 
Tabela 5

Investimentos previstos 2007-2012, PIB 2005 e princ ipa is a tividades - Espínito Sa nto

\begin{tabular}{|c|c|c|c|c|c|}
\hline Micromegião & $\begin{array}{l}\text { Invest } \\
\text { previstos } \\
2007\end{array}$ & $\%$ & PIB 2005 & $\%$ & Principais atividades \\
\hline Região Metropolitana & $18,725,600$ & 33.8 & $29,792,898$ & 63.1 & $\begin{array}{l}\text { Mineração, construção civil, } \\
\text { logística, sidenurgia, energia } \\
\text { elétrica e gás. }\end{array}$ \\
\hline Metrópole Expandida Sul & $18,296,900$ & 33 & $2,133,899$ & 4.5 & $\begin{array}{l}\text { Sidenurgia, atividade petrolífera } \\
\text { e mineração. }\end{array}$ \\
\hline Pólo Linhares & $10,413,200$ & 18.8 & $4,518,877$ & 9.6 & $\begin{array}{l}\text { Atividade petrolífera, indústria } \\
\text { naval, infra-estrutura e } \\
\text { silvicultura. }\end{array}$ \\
\hline Polo Cachoeiro & $3,073,400$ & 5.5 & $2,924,182$ & 6.2 & $\begin{array}{l}\text { Atividade petrolífera, transporte } \\
\text { fenoviario e energia elétrica } \\
\text { (geração e distribuição). }\end{array}$ \\
\hline Litoral Norte & $2,710,800$ & 4.9 & $1,671,054$ & 3.5 & $\begin{array}{l}\text { Ativida de petrolífera e geração } \\
\text { de energia elétric } a \text {. }\end{array}$ \\
\hline Polo Colatina & 777,2 & 1.4 & $1,474,137$ & 3.1 & $\begin{array}{ll}\text { Fabricação } & \text { de produtos } \\
\text { a limentícios, } & \text { bebidas e } \\
\text { combustível; } & \text { Infra-estrutura } \\
\text { (transporte, } & \text { energia e } \\
\text { telecomunicações). }\end{array}$ \\
\hline Extremo Norte & 578,6 & 1 & 668,639 & 1.4 & $\begin{array}{l}\text { Indústria sulcroalcooleira e } \\
\text { construção civil (ha bitação). }\end{array}$ \\
\hline Sudoeste Serrana & 507,2 & 0.9 & 873,856 & 1.9 & $\begin{array}{l}\text { Geração de energia elétrica, } \\
\begin{array}{l}\text { produção de bebidas e } \\
\text { agricultura. }\end{array}\end{array}$ \\
\hline Noroeste II & 175,3 & 0.3 & 857,293 & 1.8 & $\begin{array}{l}\text { Benefic iamento de rochas } \\
\text { omamentais, energia elétrica e } \\
\text { infra-estrutura rodoviária. }\end{array}$ \\
\hline Caparaó & 105,1 & 0.2 & 848,708 & 1.8 & $\begin{array}{l}\begin{array}{l}\text { Energia elétrica (geração) e } \\
\text { silvic ultura. }\end{array} \\
\end{array}$ \\
\hline Central Serrana & 38,2 & 0.1 & 843,955 & 1.8 & Infra-estrutura rodoviária. \\
\hline Noroeste I & 36,5 & 0.1 & 583,416 & 1.2 & $\begin{array}{l}\text { Distribuição de gás, extração e } \\
\text { beneficiamento de rochas } \\
\text { omamentais. }\end{array}$ \\
\hline Espírito Santo & $55,438.000$ & 100,0 & $47,190,914$ & 100,0 & \\
\hline
\end{tabular}

Fonte: Geres/Bandes, Invest-ES, SEAMA/IEMA, diversa s empresas, joma is e revista

Elaboração: IJ SN - Coordenação de Estudos Ec onômicos

Nota: Foram considera dos investimentos de valor igual ou superior a R 1 milhão.

litorâneas limítrofes à RMGV faz com que os limites socioeconômicos do complexo urbano não mais coincidam com os limites institucionais. Fluxos de capitais, mercadorias, serviços, pessoas, comunicação e informação se intensificam, gerando fluxos tipicamente intrarregionais.

$\mathrm{Na}$ medida em que o mercado passa a ser organizado em escala mundial, que supera em muito a escala do lugar, apresentando alta mobilidade no território, a consequência lógica, ao se elaborar e estruturar um plano de longo prazo, é pensar em oferecer condições competitivas na infraestrutura de circulação do território para esses grandes projetos, como a 
modernização dos portos, aeroportos e a privatização de rodovias e ferrovias, para atender a essa demanda das empresas por fluidez territorial. O ciclo do petróleo e gás no estado é relativamente recente e conta com um "player" importante no foco das decisões de investimentos, especialmente pela Petrobrás. Para assegurar a viabilidade desses empreendimentos, relativamente isolados do tecido urbano mais denso, o Estado pensa em implantá-los por meio de intervenções de grande porte, justificando os investimentos em logística e em infraestrutura, previstos no Plano 2025.

Aos investimentos previstos pelo governo estadual para o estado do Espírito Santo no período 2007-2012, devemos acrescentar os recursos referentes aos investimentos do $\mathrm{PAC}^{47}$, que não estão computados nos estudos apurados pelo levantamento sistemático realizado pelo governo. No estado do Espírito Santo, os principais objetivos do PAC para o setor energético são garantir a segurança energética e o equilíbrio tarifário entre os estados pertencentes à Região Sudeste; ampliar a malha de gasodutos necessária ao suprimento de gás natural; desenvolver e ampliar a produção de gás e petróleo, assim como modernizar o parque de refino estadual. Considerando os investimentos destinados pelo PAC ao Espírito Santo no período até 2010, o montante de recursos totaliza $\mathrm{R} \$ 55,7$ bilhões (Tabela 6) dos quais $\mathrm{R} \$ 21,3$ bilhões (Tabela 7) se concentram nas atividades de infraestrutura energética $\left(38,2 \%\right.$,em termos percentuais, do total previsto). ${ }^{48}$

Se por um lado, a concentração dos recursos federais está alocada na questão energética, por outro lado, os investimentos destinados à infraestrutura social e urbana são ínfimos. Tais investimentos representam apenas $5,2 \%$ do montante investido e têm como projetos prioritários: a universalização do acesso à energia elétrica até 2008 - Programa Luz para Todos; a melhoria das condições de vida da população, garantindo o abastecimento de água nos municípios da Grande Vitória; a despoluição da baía de Vitória, com a duplicação da coleta e do tratamento de esgotos da Região Metropolitana da Grande Vitória; a ampliação dos sistemas de esgotamento sanitário de alguns municípios do interior do estado; e a erradicação de

47 PAC - Programa de Aceleração do Crescimento lançado pelo governo federal, que tem como objetivo principal alavancar a recuperação de infraestrutura, de modo a eliminar gargalos e viabilizar o crescimento da economia brasileira.

48 BRASIL - PAC,2008. Disponível em < htttp://www.brasil.gov.br/PAC/estados> Acesso em 10 ago 2009 
Tabela 6

Investimento do Espírito Santo - PAC

\begin{tabular}{c|c}
\hline INVESTIMENTO ES - PAC & $\mathbf{5 9 , 9}$ bilhões \\
\hline Até 2010 & 55,7 bilhões \\
\hline Pós 2010 & 24,2 bilhões \\
\hline
\end{tabular}

Fonte: PAC/Govemo Federal.

Tabela 7

Investimentos PAC por setor de ativida de - 2007-2010

\begin{tabular}{l|c|c|c|c}
\hline \multirow{2}{*}{ EXO } & \multicolumn{2}{|c|}{$\begin{array}{r}\text { Empreendimentos } \\
\text { Exclusivos } \\
\text { (R\$ milhões) }\end{array}$} & $\begin{array}{r}\text { Empreendimentos Caráter } \\
\text { Regional } \\
\text { (R\$ milhões) }\end{array}$ \\
\cline { 2 - 5 } & $\mathbf{2 0 0 7 - 2 0 1 0}$ & Pós 2010 & $\mathbf{2 0 0 7 - 2 0 1 0}$ & Pós 2010 \\
\hline Logística & 761,1 & 318,3 & $5.100,00$ & -- \\
\hline Energética & $\mathbf{2 1 . 3 1 3 , 2}$ & $\mathbf{2 3 . 3 0 6 , 3}$ & $\mathbf{6 . 2 8 3 , 6}$ & $\mathbf{6 1 1 , 4}$ \\
\hline Social e Urba na & $2.255,8$ & -- & -- & -- \\
\hline Total & $\mathbf{2 4 . 3 3 0 , 1}$ & $\mathbf{2 3 . 6 2 4 , 6}$ & $\mathbf{1 1 , 3 8 3 , 6}$ & $\mathbf{6 1 1 , 4}$ \\
\hline
\end{tabular}

Fonte: PAC/Govemo Federal.

palafitas e remoção de moradias localizadas em beiras de córregos e áreas de risco

Já os investimentos em infraestrutura logística, que correspondem a 4,5\% do montante previsto para o Estado, buscam assegurar a ampliação da infraestrutura logística existente, com vistas a melhorar o escoamento da produção regional, tanto para o consumo interno quanto para a exportação (melhoria da infraestrutura viária da BR-101 e a dragagem do Porto de Vitória). Outro ponto de fundamental importância para a estrutura logística, considerado no PAC, é a construção do novo terminal de passageiros, do terminal de cargas, da torre de controle e do sistema de pista do novo aeroporto de Vitória.

Observa-se que os projetos das redes de cidades e os da logística de transportes estão intrinsecamente associados, na concepção do Plano 2025. Em geral, o bom desempenho das commodities metálicas no mercado internacional demanda das grandes empresas do setor siderúrgico e de mineração a ampliação das suas tecnologias de operação, desde sua rede de transportes até a capacidade produtiva instalada de suas plantas industriais. Considerando os dados setoriais pela Classificação Nacional de Ativida- 


\section{Tabela 8}

Princ ipa is a tividades de investimentos no Espínito Santo

\begin{tabular}{|c|c|c|c|}
\hline CNAE & Classificação & Milhões R\$ & $\%$ \\
\hline 27 & Metalurgia Básica & 10.137 & 18,3 \\
\hline 11 & Extração de Petróleo e Serviços Relaciona dos & 9.240 & 16,7 \\
\hline 13 & Extração de Minera is Metálicos & 8.564 & 15,4 \\
\hline 23 & $\begin{array}{l}\text { Fabricação de Coque, Refino de Petróleo, } \\
\text { Elaboração de Combustíveis Nucleares e } \\
\text { Produção de Álcool }\end{array}$ & 6.447 & 11,6 \\
\hline 45 & Construção & 4.111 & 7,4 \\
\hline 35 & $\begin{array}{l}\text { Fabricação de Outros Equipamentos } \\
\text { Transporte }\end{array}$ & 3.462 & 6,2 \\
\hline 63 & $\begin{array}{l}\text { Atividades Anexas e Auxilia res dos Transportes } \\
\text { e Agências de Viagem }\end{array}$ & 3.243 & 5,8 \\
\hline 40 & Eletric idade, Gáse Água quente & 2.988 & 5,4 \\
\hline 60 & Transporte terrestre & 1.069 & 1,9 \\
\hline 15 & $\begin{array}{l}\text { Fabricação de Produtos Alimentícios e } \\
\text { Bebidas }\end{array}$ & 971 & 1,8 \\
\hline 2 & $\begin{array}{l}\text { Silvicultura, Exploração Florestal e Serviços } \\
\text { Relacionados }\end{array}$ & 657 & 1,2 \\
\hline 55 & Alojamento e Alimentação & 627 & 1,1 \\
\hline 85 & Saúde e Serviç os Soc ia is & 375 & 0,7 \\
\hline Outros & & 3.550 & 6,4 \\
\hline \multicolumn{2}{|c|}{ Total Espírito Santo } & 55.438 & 100,0 \\
\hline
\end{tabular}

Fonte: Geres/Bandes, Invest-ES, SEAMA/IEMA, diversas empresas.

Ela boração: IJ SN- Investimentos 2007-2012

de (CNAE), verifica-se que 18,3\% do montante a ser investido está concentrado na metalurgia básica, que corresponde à instalação, ampliação e modernização da indústria siderúrgica capixaba. A extração de petróleo e serviços relacionados participam com 16,7\% das intenções de investimentos, concentrados na perfuração e extração e no transporte de petróleo e gás natural (Tabela 8). 
FG.17

Mapa de Distribuição dos Investimentos 2007-2012. Fonte: IJ SN - Coordenação de Estudos Econômicos

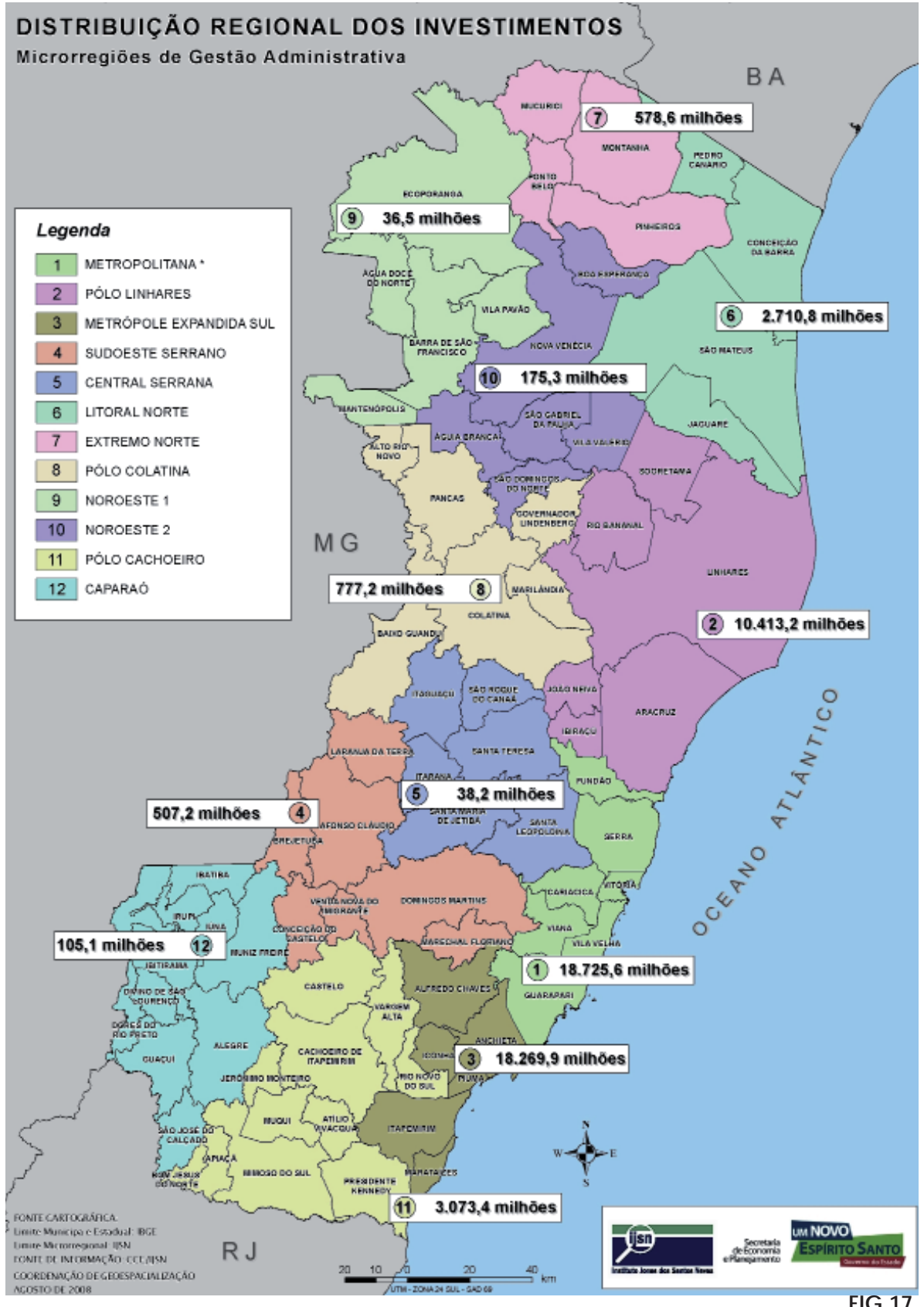

HG.17

É importante ressaltar que o modelo econômico adotado no Espírito Santo tem por base a siderurgia ${ }^{49}$. Esse modelo pode levar a distorções no mercado, ou seja, as empresas com menor poder de concorrência e portadoras de lógicas propriamente territoriais locais tornam-se mais vulneráveis à força de penetração das grandes empresas, enquanto as empresas

49 O principal produto exportado, de janeiro a setembro 2007, é o minério de ferro, aglomerados e concentrados, com participação de $44 \%$. Os semimanufaturados de ferro e aço correspondem a mais $9 \%$. Ou seja, a pauta mínero-siderúrgica supera metade das exportações. Fonte: SIMÕES, Roberto. ES visto pela China. A Gazeta. Vitória, Opinião, 23 out 2007. 
multinacionais ampliam a sua participação no mercado interno. Essa situação faz com que a economia capixaba fique mais suscetível às oscilações do mercado global, o que pode comprometer o quadro econômico e social do estado diante de eventuais crises globais.

\subsubsection{Desenvolvimento da logística e de circulação de mercadonias}

O investimento em logística visa aumentar a eficiência da rede de transportes, de modo a conferir vantagem competitiva às empresas e aos sistemas produtivos, além de favorecer a integração entre regiões. A logística é um dos fatores estratégicos para o desenvolvimento social e econômico do Estado do Espírito Santo em face de sua potencialidade quanto aos recursos disponíveis para a expansão e fortalecimento do estado nas relações comercias com o mercado nacional e internacional. O potencial dos modais de transporte do Espírito Santo é representado por um complexo portuário considerado eficiente, que se opera com sete portos: Vitória, Tubarão (Serra), Capuaba (Vila Velha) Praia Mole (Serra), Barra do Riacho, Regência (Linhares) e Portocel (Aracruz) e Ubu (Anchieta). Por ocuparem posições estratégicas no território nacional, os portos capixabas recebem mercadorias de diversos estados da federação, como Minas Gerais, Goiás, Mato Grosso do Sul e Bahia. Devido a essa potencialidade logística, o estado vem recebendo investimentos nos principais setores econômicos ${ }^{50}$. Apesar dos gargalos existentes, a logística de circulação de mercadorias também se complementa por meio dos canais de integração rodoferroviária.

Acompanhando os resultados brasileiros, as exportações e importações dos portos do estado do Espírito Santo, em 2005, foram extremamente significativas tanto para o comércio exterior capixaba como para o Brasil, devido a seu grau de importância e sua participação no total comercializa-

50 Para os demais estados, o somatório de seus portos apresenta a seguinte classificação para os estados brasileiros. Em primeiro lugar está o estado de São Paulo, com 34,44\% do total exportado pelo Brasil; em segundo ficou o Rio Grande do Sul; em terceiro o Rio de Janeiro. O Espírito Santo ocupou o quarto lugar, seguido do Paraná. No caso das importações, os portos do Espírito Santo participaram com apenas $6,63 \%$ do valor total brasileiro, o que equivale a US $\$ 4,9$ bilhões, representando um crescimento de $51,2 \%$ em relação a 2004 (US \$ 3,2 bilhões). Com isso os portos do Espírito Santo passaram da sexta colocação para a quarta no que diz respeito ao total importado por unidades da Federação. Fonte: SECRETARIA DE ESTADO DA ECONOMIA E PLANEJAMENTO do GOVERNO DO ESTADO DO ESPÍRITO SANTO. Estatísticas de Comércio Exterior 2005: Portos do Espírito Santo. IJSN Vitória. 2006. 


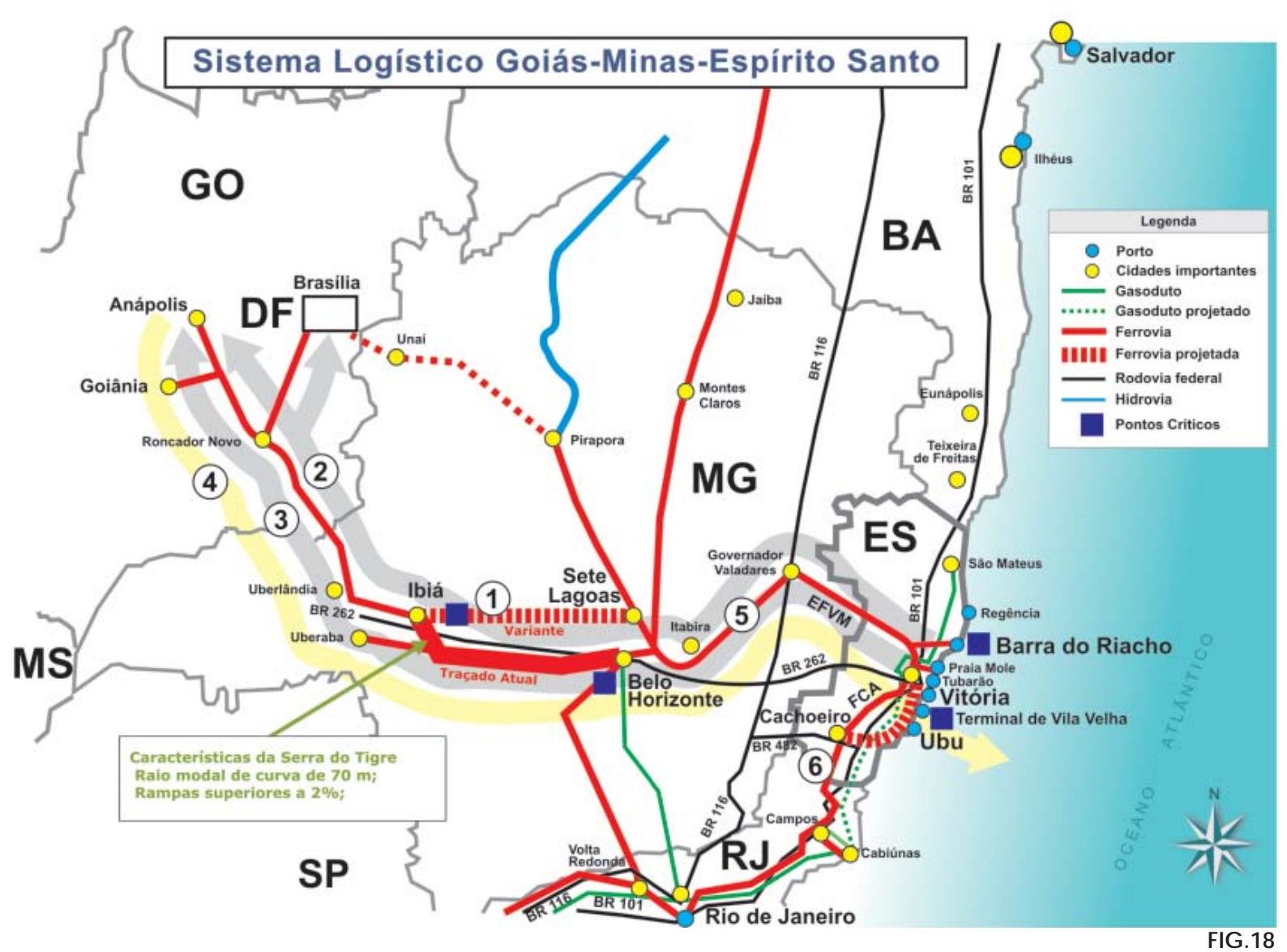

FG.18

Sistema Logístico GoiásMinas Gerais - Espínto SantoFonte: IJ SN do pelo país ${ }^{51}$. No acompanhamento ao longo dos anos, os números vêm crescendo com o aumento da movimentação de cargas do próprio estado e de estados vizinhos, que utilizam as vantagens competitivas dos portos do Espírito Santo, apesar dos gargalos na infraestrutura das malhas rodoviárias, ferroviárias e de alguns portos.

Os portos capixabas recebem incentivos, como o Fundap ${ }^{52}$, que favore-

51 Em 2005, o crescimento das exportações dos portos foi 30,4\% superior ao de 2004, saltando dos US $\$ 8,7$ bilhões para US\$11,4 bilhões. Esse resultado significa, no total geral, um aumento na participação dos portos capixabas de $9,04 \%$ para $9,61 \%$ do valor total exportado pelo país. Fonte: SECRETARIA DE ESTADO DA ECONOMIA E PLANEJAMENTO do GOVERNO DO ESTADO DO ESPÍRITO SANTO. Estatísticas de Comércio Exterior 2005: Portos do Espírito Santo. IJSN Vitória. 2006.

52 Com o auxílio do Fundo para o Desenvolvimento das Atividades Portuárias (Fundap) o Espírito Santo compete com os grandes estados importadores, devido ao incentivo proporcionado por esse fundo que estimula empresas de outros estados a buscarem benefícios e a se instalarem no estado ou contratarem empresas que recebem incentivos desse fundo (as chamadas empresas fundap )para efetuarem suas importações. Uma realidade a ser constatada é que a maior parte das importações efetuadas pelos portos capixabas não se destina às empresas capixabas. Mais de $90 \%$ do total importado tem como destino outros estados, como São Paulo, Rio de Janeiro, Minas Gerais, Bahia, entre outros. Isso demonstra que os portos do Espírito Santo praticamente representam um entreposto que recebe os produtos do exterior e os encaminha para seu destino final, ficando com uma pequena fatia desse montante. 


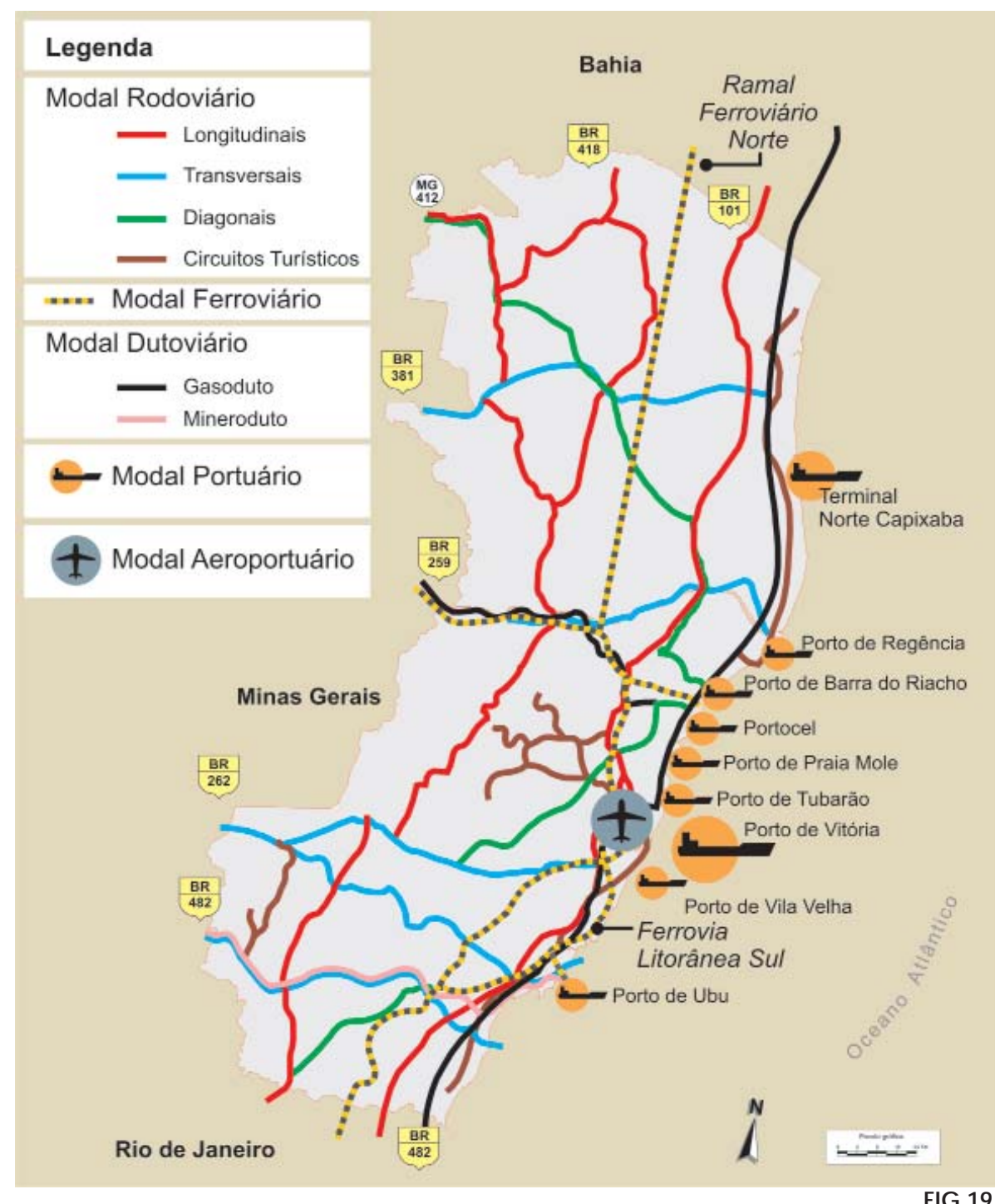

HG.19
HG.19

Logística portuária e de transportes proposto pelo Plano 2025. Fonte: Governo do Estado do Espíito Santo. Plano de Desenvolvimento 2025 .

\section{RG.20}

Esquemático dos projetos logística elencados no Plano 2025 do Govemo do Estado Espínito Santo. Fonte: A Gazeta. $28 / 08 / 2007$

cem as importações. Com tais incentivos, o Espírito Santo proporciona aos importadores algumas vantagens fiscais que outros estados, por vezes, não oferecem, e isso estimula as empresas na prestação de serviços inerentes ao transporte e ao comércio exterior. Apesar do alto valor importado pelo Espírito Santo, as mercadorias que chegam ao estado são destinadas, em sua quase totalidade, a outros estados da federação e ao exterior ${ }^{53}$.

53 Em 2005, dentro da classificação categorias de uso segundo seu valor agregado, destacam-se as matérias-primas e produtos intermediários (MP/PI), que representaram 97,9\% das exportações

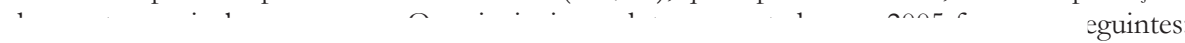
minério de ferro aglomerado, pasta química de madeira, minério de ferro não aglomerado, ferro fundido bruto, semimanufaturados de ferro e aço e grãos de soja triturados. Em primeiro lugar nas exportações dos portos do Espírito Santo, ficou o minério de ferro aglomerado (US\$ 2.535 bilhões); sua participação foi de $22,3 \%$ do total das exportações do ano. A pasta química de madeira (celulose), exportada pela Aracruz Celulose por meio do Porto de Barra do Riacho, foi o segundo produto mais comercializado em termos de valores; as exportações de celulose atingiram US 1.400 bilhão, o que representa uma participação de 12,3\% no total dos portos do estado em 

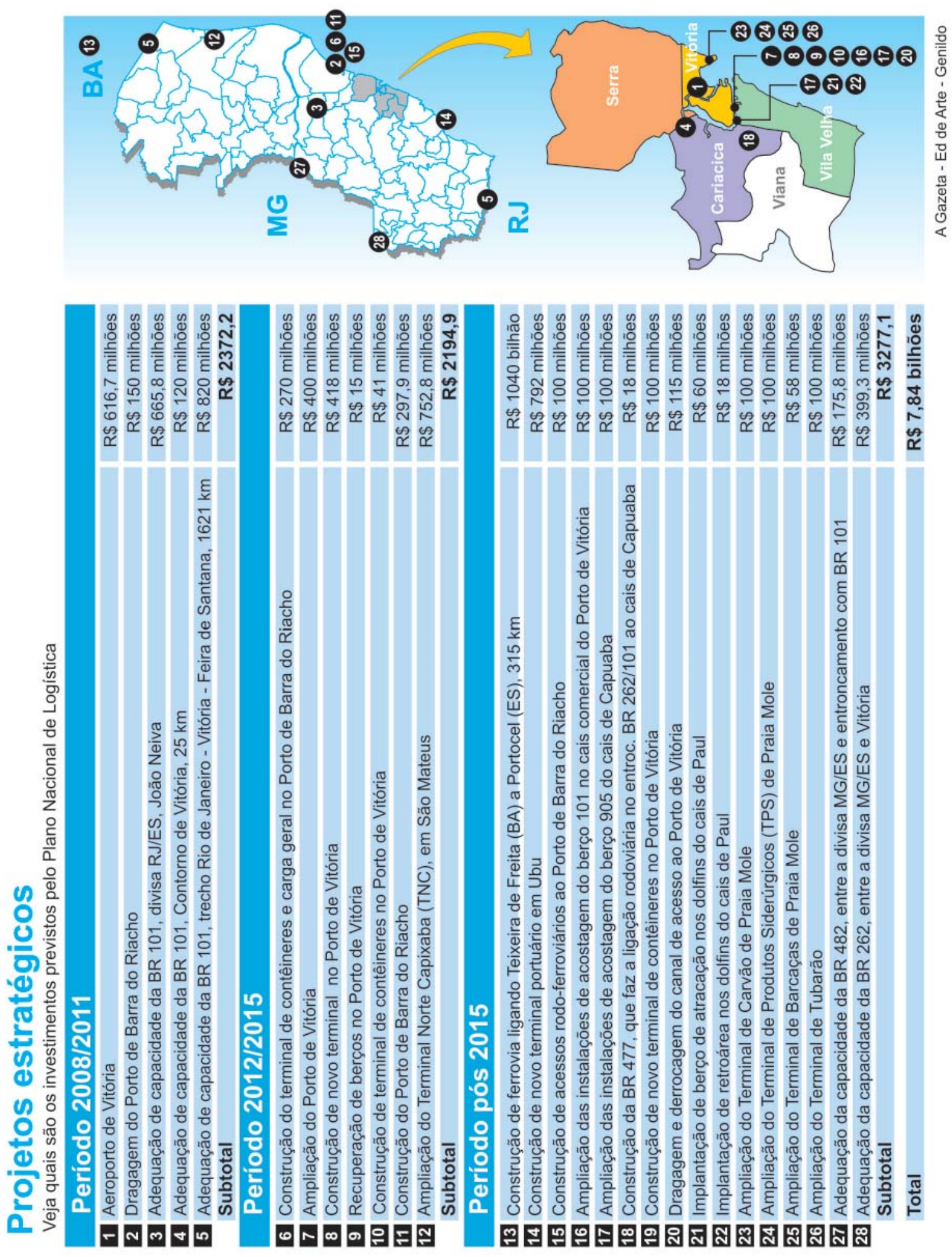

FG.20 
Com a reestruturação geopolítica mundial e novas formas de divisão internacional do trabalho, aumenta o tráfego marítimo e o surgem novas técnicas de produção e de transporte. Tais condições fazem com que o porto passe progressivamente da função meramente de transbordo de mercadorias para ingressar em um processo mais empresarial. O complexo portuário favorece a localização e a ampliação de grandes empreendimentos industriais voltados para o mercado externo, como a CVRD( Porto de Tubarão e Praia Mole), a SAMARCO (Porto de Ubu), a CST (Porto de Tubarão) e a ARACRUZ CELULOSE (Portocel e Barra do Riacho), PETROBRÁS (Porto de Regência). Essas empresas têm investido de forma maciça em suas plantas industriais com o objetivo de aumentar a produtividade e melhorar a qualidade da matéria exportada, assim como têm demandado do governo estadual melhorias em logística de transporte.

Há também o crescimento do setor de rochas da região, polarizado pelo município de Cachoeiro de Itapemirim ${ }^{54}$. Apesar do potencial, a exploração de mármore e granito na região ainda enfrenta muitos desafios, segundo o presidente do Sindicato das Indústrias de Rochas Ornamentais, Cal e Calcários do Espírito Santo (Sindirochas), Áureo Mameri: “a maior dificuldade que o segmento enfrenta hoje é o transporte de matéria-prima. O transporte rodoviário encarece em $10 \%$ o produto, por isso é necessário investir em outros meios de transporte, menos onerosos e mais seguros, como a malha ferroviária" ${ }^{55}$. O projeto de construção da Ferrovia Litorânea Sul proposto no Plano 2025, cujo percurso chega até o Porto de Ubu, em Anchieta, também tem por objetivo atender a este propósito.

As operações logísticas, como vantagem competitiva, necessitam de um alto padrão operacional, que passa, inevitavelmente pelo processo gerencial, com foco na utilização plena de cada modal e da intermodalidade. A renovação portuária é, portanto, entendida como articulada à governança estatal, mediante convergência de conjunção de esforços ao longo do 
tempo, tendo em vista garantir a competitividade na atração de investimentos. Sendo o Espírito Santo um portal de importação e exportação, a conjuntura econômica depende também, para a sua competitividade, da qualidade da infraestrutura rodoferroviária; entretanto, parte dessa infraestrutura se encontra fora de seu território, sob jurisdição federal. E o não enfrentamento dessa questão por parte da União diminui a eficiência e a competitividade do sistema capixaba. O desempenho econômico do Espírito Santo está, portanto, intrinsecamente ligado à superação da ineficiência do sistema logístico de transportes e nas suas interligações com outros estados.

Diante dos gargalos negativos existentes, o Plano 2025 prevê a necessidade de investimentos no setor portuário e na logística de transportes, interligando as malhas ferroviária, rodoviária e aeroviária aos portos, estruturando diversos projetos, que, por sua vez, complementam e viabilizam os demais contemplados na carteira de projetos.

Outro fator de extrema importância que vem se desenvolvendo no Espírito Santo nos últimos anos são as descobertas de petróleo no litoral capixaba, com instalação da sede da Petrobrás na capital. As atividades petrolíferas no Espírito Santo tiveram início há mais de três décadas, na Região Norte, nos municípios de São Mateus e Conceição da Barra. Depois de períodos de alta, em meados dos anos 1980, e de baixa, na metade dos anos 1990, sua atividade foi revigorada. O fortalecimento das atividades de exploração do petróleo, capitaneado pela Petrobras, deu-se pela descoberta de novos campos, tanto em terra quanto em mar, que devem trazer vultosos recursos para o estado. Das novas descobertas, as camadas de pré-sal são as mais destacadas em índices de ocorrência. As descobertas aconteceram no litoral sul capixaba, nos limites geográficos de Itapemirim, Marataízes, Presidente Kennedy, Piúma e Anchieta que, justamente, integram a Microrregião Metropolitana Expandida Sul, destacando-se os campos de exploração Parque das Baleias, Parque das Conchas, Jubarte, Peroá, Golfinhos e Cachalote (Figura 21).

O Espírito Santo tem, hoje, 12\% da reserva nacional de petróleo e 23\% da carteira de exploração da Petrobrás. Além da exploração do petróleo em si, no litoral, e da possibilidade de uma refinaria, há grandes perspectivas 


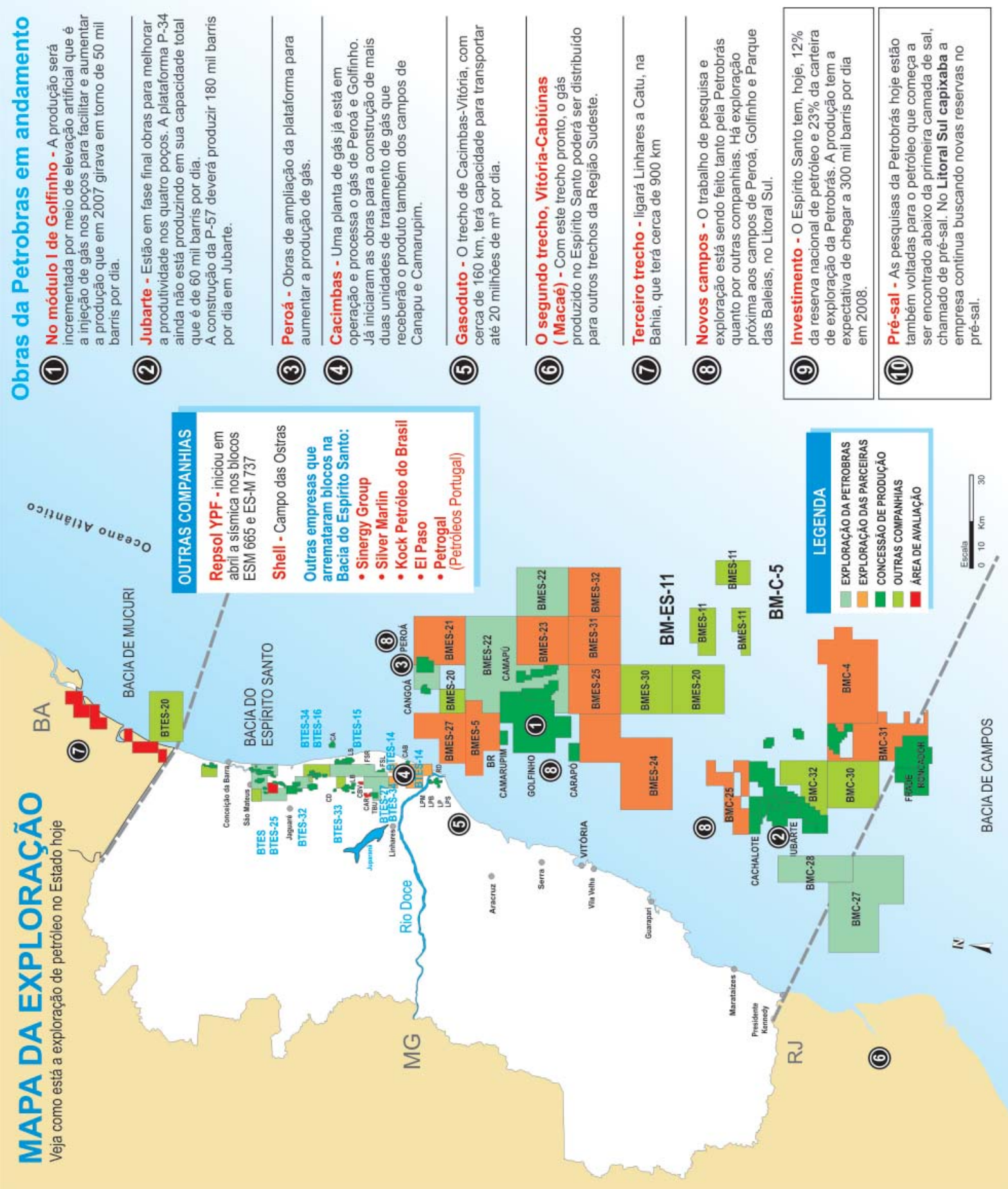

de empresas de apoio e serviços de suporte àquelas de exploração no mar.

E, por fim, com o aumento da produção, a consequência mais imediata é o aumento da arrecadação de royalties por parte de algumas prefeituras da Microrregião Expandida Sul, como Presidente Kennedy, Marataízes, Itapemirim, Piúma e Anchieta. O valor de investimentos que a Petrobras pretende fazer nos próximos cinco anos no Espírito Santo é da ordem de 
RG.21

Mapeamento dos campos de exploração ao longo do litoral do ES. Fonte: A Gazeta 10/06/2007. Tratamento de imagens: Eugênio Herkenhoff

HG.22

Percurso da Unidade de Tratamento de Gás (UTG) sul. Fonte: A Gazeta. 2009 Tratamento de imagens: Eugênio Herkenhoff

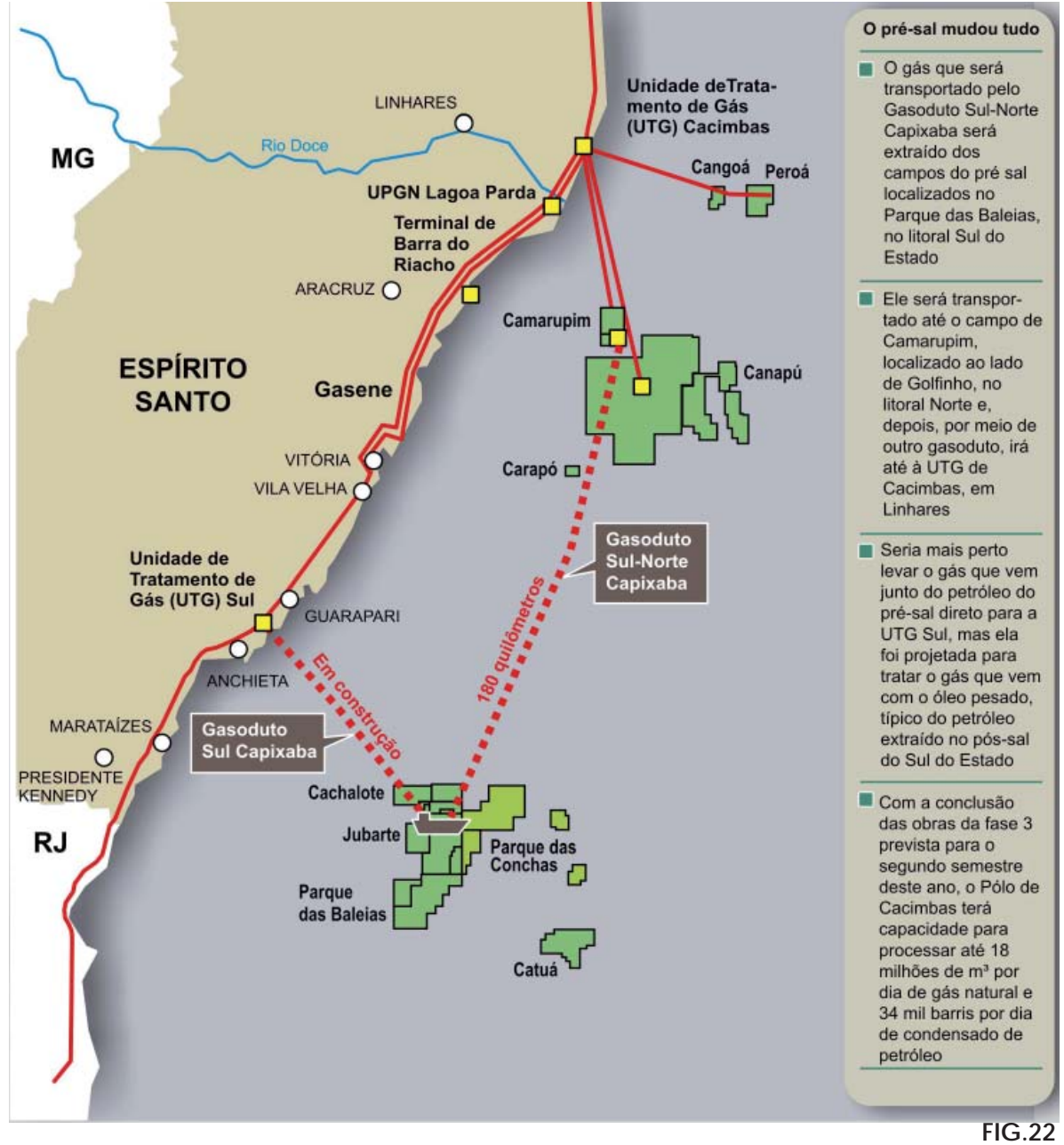

R \$17bilhões, conforme previsto no plano estratégico da companhia estatal $^{56}$. No momento, os estados federados como São Paulo, Rio de Janeiro e Espírito Santo estão na briga com o governo federal para assegurar que os royalties permaneçam no território onde ocorre a exploração.

Com uma produção, hoje, em torno de 8 milhões de $\mathrm{m}^{3}$ por dia de gás natural, a Petrobrás já distribui parte do gás produzido no estado para o Rio de Janeiro por meio do Gasene - rede de dutos que liga o Sudeste ao Sul e que, a partir de 2010, ligará também o Sudeste ao Nordeste do país. A produção capixaba de gás natural deverá girar em torno de 20 milhões de $\mathrm{m}^{3}$ por dia, e parte dessa produção deverá abastecer indústrias termoelétricas que já entrarão em operação. Entre os projetos elencados no Plano 2025, está prevista a construção, pela Petrobrás, de um gasoduto de $180 \mathrm{~km}$ que

56 PETROBRÁS vai construir gasoduto de $180 \mathrm{~km}$ no litoral do Estado. A GAZETA, Vitória, 5 abr 2009. Economia. 
ligará os campos da camada de pré-sal do Litoral Norte, mais especificamente o Parque das Baleias ao campo de Camarupim, e este será ligado à Unidade de Tratamento de Gás (UTG) de Linhares. O gás produzido nos campos de Jubarte, Cachalote, Anã, Azul, Franca (óleo pesado) será processado na Unidade de Tratamento de Gás (UTG) sul, que está em construção em Ubu, no município de Anchieta (Figura 22). O gasoduto ainda está em fase de detalhamento de projeto.

Esses novos condicionantes do espaço econômico que se desenrolam no território determinam um processo de metropolização mais amplo, estendendo-se da RMGV para o litoral sul, o que deverá promover uma reestruturação físico-territorial que necessariamente implica expressivas mudanças dos perfis econômicos e sociais do território estadual. Essa nova situação do litoral sul, instituída a partir de uma série de investimentos em tecnologias, deverá promover uma dinâmica acentuada com surgimento de diversificadas atividades, ficando a Microrregião Expandida Sul com tendência de consolidar-se como importante polo mínero-siderúrgico de referência nacional e internacional.

\footnotetext{
Os sistemas de engenharia que antes eram praticamente subordinados às condições locais, são, cada vez mais, tributários de relações mais amplas. De um controle pulverizado à escala de comunidades isoladas, passarem a depender de um controle unificado que preside a um jogo complexo, social e economicamente, que, hoje, caracteriza a utilização de infra-estruturas instaladas segundo regras científicas e técnicas restritas. O uso do território é marcado, de um lado, por uma fluidez, com menos fricções e rugosidades e, de outro, pela fixidez, dada por grandes projetos, cujas localizações devem ser adequadas e precisas. A expansão desse meio-técnico-informacional é seletiva, com o reforço de algumas regiões e o enfraquecimento relativo de outras.
}

(SANTOS, 2005, p.295)

É interessante observar como o Estado, de modo geral, se comporta em cada um dos domínios territoriais, com condutas e soluções diferenciadas conforme seja o grau de exigência e das demandas do circuito produtivo empresarial. Pela repartição das infraestruturas no território e pela escolha daquelas que beneficiam um determinado setor da produção e da população, a instância política dá respaldo à localização das empresas, segundo 
Tabela 9

Princ ipa is investimentos no Espínito Santo, por ordem decrescente de valor - 2008-2013

\begin{tabular}{|c|c|c|c|c|c|}
\hline Ordem & Projeto & Setores & Descrição & Município & Micromegião \\
\hline 10 & \begin{tabular}{|l} 
Ferrous \\
Resources do \\
Brasil LTDA \\
\end{tabular} & Indústria & $\begin{array}{l}\text { Implantação de um complexo } \\
\text { portuário com } 3 \text { usinas de pelotização } \\
\text { e um mineroduto, além de um porto } \\
\text { de águas profundas. }\end{array}$ & $\begin{array}{l}\text { Presidente } \\
\text { Kennedy }\end{array}$ & $\begin{array}{l}\text { Pólo } \\
\text { Cachoeiro }\end{array}$ \\
\hline $2^{\circ}$ & Petrobras S/A & Energia & $\begin{array}{l}\text { Perfuração, testes e exploração nos } \\
\text { poços do bloco BC-60 (Jubarte e } \\
\text { demais poços). }\end{array}$ & $\begin{array}{l}\text { Presidente } \\
\text { Kennedy }\end{array}$ & $\begin{array}{l}\text { Pólo } \\
\text { Cachoeiro }\end{array}$ \\
\hline 3o & Petrobras S/A & Energia & $\begin{array}{l}\text { Inicio da primeira fase de exploração } \\
\text { do campo do golfinho (poço ESS 132) } \\
\text { que começa em maio } 2006 .\end{array}$ & Aracruz & Pólo Linhares \\
\hline 40 & $\begin{array}{l}\text { Ferrovia } \\
\text { Litorânea Sul } \\
\text { (VALE) }\end{array}$ & Transporte & $\begin{array}{l}\text { Construção da ferrovia ligando Vitória } \\
\text { à Cachoeiro de Itapemirim passando } \\
\text { pelo litoral com } 165 \mathrm{~km} \text {. }\end{array}$ & $\begin{array}{l}\text { Vitónia/ } \\
\text { Cahoeiro } \\
\end{array}$ & $\begin{array}{l}\text { Metropolitana } \\
\text { /Pólo } \\
\text { Cachoeiro } \\
\end{array}$ \\
\hline 5은 & $\begin{array}{l}\text { Petrobras S/A - } \\
\text { Implantação do } \\
\text { Projeto } \\
\text { Camarupim }\end{array}$ & Energia & $\begin{array}{l}\text { Investimentos em Desenvolvimento da } \\
\text { Produção (Poços, linha de coleta, } \\
\text { gasodutos maŕtimose plataforma). }\end{array}$ & Linhares & Pólo Linhares \\
\hline 60 & Petrobras S/A & Energia & Plataforma FPSO P-58. & Linhares & Pólo Linhares \\
\hline 70 & Petrobras S/A & Energia & Platafoma FPSO P-57. & Linhares & Pólo Linhares \\
\hline 8음 & Petrobras S/A & Energia & $\begin{array}{l}\text { Ampliação da capacidade de } \\
\text { Processamento de Gás Natural (UPGN) } \\
\text { para } 20 \text { milhões } \mathrm{m}^{3} / \mathrm{d} \text {. }\end{array}$ & Linhares & Pólo Linhares \\
\hline 9o & Petrobras S/A & Energia & $\begin{array}{l}\text { UTGC fase III Instalação de } 2 \text { UPNG e } 2 \\
\text { unidades de processamento de } \\
\text { condensado (UPCGN). }\end{array}$ & Linha res & Pólo Linhares \\
\hline 10 은 & VALE & Indústria & \begin{tabular}{lllll|}
$\begin{array}{l}\text { Construção } \\
\text { pelotização. }\end{array}$ & da & 8o & usina & de \\
\end{tabular} & Serra & Metropolitana \\
\hline
\end{tabular}

Fonte: Bandes, Invest-ES, Seama/ IEMA, Sedes, Sedu, Sesa, Sesp, Cesan, diversa s empresas, joma is e revistas.

Elaboração: IJ SN - Coordenação de EstudosEconômic os

Nota: Foram considerados os investimentos de valor igual ou superior a R\$ 1 milhão.

características específicas do espaço nacional, conforme ressalta Santos: "tem-se o poder discricionário que é dado ao Estado de criar novas atividades, de defini-las e de localizá-las ao seu alvedrio, sem relação com as demandas das outras instâncias sociais.” (SANTOS,1979,p.46). O impacto dessa conjuntura técnico-econômica na Microrregião Expandida Sul deverá provocar mudanças significativas no litoral sul em função de uma nova reestruturação do circuito espacial de produção.

Em decorrência dessas inovações tecnológicas, estima-se que também a Região Metropolitana da Grande Vitória fortalecerá, nas próximas décadas, seu papel de principal centro urbano do Estado, atraindo investimentos estratégicos capazes de promover o adensamento e a especialização de suas áreas periféricas e reforçando, assim, progressivamente, a integração intrarregional e a complementariedade das atividades instaladas nos mu- 
nicípios metropolitanos. Considerando todo esse novo perfil, é notável, enfim, um crescimento mais acelerado e a inserção maior da metrópole da Grande Vitória na dita "Região Concentrada ${ }^{57}$."

\subsubsection{Imagem e comunicação do plano}

O Plano 2025 tem como uma das suas estratégias de ação o "fortalecimento da identidade capixaba e imagem do Estado". Nessa perspectiva, o Plano tem por objetivo "promover o conhecimento do Espírito Santo no Brasil e no mundo, disseminando e resgatando uma imagem positiva de modo a enfatizar os atributos que caracterizam a identidade capixaba"58 . Segundo os argumentos do Governo do Estado, constata-se a inexistência de uma imagem nítida e forte, característica do Espírito Santo, que contribua para favorecer uma posição de destaque no cenário nacional. Esse fato prejudica a sua inserção na rede de negócios do país, e também no âmbito internacional, o que justifica, segundo o Plano, a criação de uma "valorização e divulgação da imagem".

A construção da visibilidade pela política pública vai dos grandes planos aos detalhes, da descrição narrativa à efetiva implementação, seja pela mídia, seja pela propaganda oficial dos projetos vinculados ao Plano 2025, numa tentativa de associar a governança a processos de modernização. Em seu escopo, o Plano apresenta uma Agenda de Implementação, Governança e Comunicação Social de modo a garantir êxito na coordenação e implantação de cada grupo de projetos, conforme texto:

\footnotetext{
A agenda de comunicação social deverá ser formulada e operada desde a etapa inicial de implantação e ao longo de todo o processo, com duas motivações principais: (1) a mobiliação dos atores públicos e privados visando à sustentação do Plano de Desenvolvimento Espírito Santo 2025; e (II) a mobilização da sociedade em apoio ao projeto. Para motivação de vários segmentos da sociedade, o processo de comunicação social será expandido de forma articulada entre os parceiros, e seu conteúdo será pautado nos resultados e transformações requeridos tanto pela visão de futuro
}

57 A Região Sul e Sudeste do Brasil foi denominada por Milton Santos de Região Concentrada por abrigar maior densidade do meio técnico em uma área contígua do território ( SANTOS \&SILVEIRA,2005,p.337)

58 GOVERNO DO ESTADO DO ESPÍRITO SANTO. Plano de Desenvolvimento 2025. 2006 
e grupos de projetos quanto por seus elementos de governança e sustentabilidade

(Plano 2025:2006,p.147)

A importância da participação da mídia e dos veículos de comunicação são evidentes no estabelecimento de parcerias, notadamente constatado na estratégia do Plano 2025, ao fortalecer e destacar como projeto âncora a "divulgação da imagem". Naturalmente existe entre os setores, público e privado uma conexão efetuada sempre por intermédio dos meios de comunicação. O destaque para a questão do discurso na preparação do território para a especialização produtiva será tratado com mais detalhes no capítulo 5 .

\subsection{As interfaces entre Estado e mercado: o movimento empre- sarial "ES em ação"}

Um dos parâmetros ideológicos mais relevantes no processo de especialização do território manifestado no Plano 2025 é a parceria entre Estado e mercado. A conjuntura política e econômica atual, caracterizada pela convergência dessa integração do público e do privado no âmbito das ações, e a crescente tendência de produção do espaço pelo mercado têm resultados evidentes na conformação sócioespacial da metrópole contemporânea. Em geral, essa parceria se faz por meio de uma postura programática e conceitual que se apropria do discurso desenvolvimentista com base no crescimento econômico para imprimir e adicionar "valor" aos seus empreendimentos, particularmente naqueles casos que envolvem ou requerem a negociação de benefícios e contrapartidas entre diversos atores sociais. Assim, cada objeto técnico tem um potencial de impacto que depende, para sua eficácia, da regulação dos atores envolvidos.

O processo de globalização tende a reforçar o poder das grandes empresas; entretanto, a necessidade de assegurar estabilidade, em âmbito interno de cada subsistema nacional, requer crescente eficiência e sofisticação na ação dos Estados. Estas relações entre mercado, Estado e sociedade são nitidamente reconhecidas e desejadas na própria concepção do Plano 2025 (ES), conforme o discurso: 
O Espírito Santo alcançará e sustentará um novo ciclo de desenvolvimento pela ampliação de capital social - confiança, cooperação e co-responsabilidade entre os atores públicos, privados e do terceiro setor - e melhoria substancial da qualidade de suas instituições nos próximos 20 anos [...] A participação de atores sociais não estatais na formulação e implementação de políticas públicas será essencial. Papel decisivo neste terreno caberá aos meios de comunicação, tanto na fiscalização e cobrança da ação pública, como na divulgação de casos de sucesso de atuação das instituições públicas estatais e não-estatais. [...] um dos frutos desta construção idealizada e planejada será o fortalecimento da identidade e uma substancial mudança da imagem do Espírito Santo. ${ }^{59}$

(PLANO 2025, 2006)

Para que possamos entender a negociação entre as grandes empresas e o estado do Espírito Santo, especialmente no contexto atual de grandes investimentos em projetos tecnológicos, é preciso, em primeiro lugar, definir basicamente quais os interesses das corporações e quais os interesses do Estado em termos de comércio internacional. Em geral, o sistema industrial formado em torno de um mercado basicamente apoiado no exterior é emblemático das economias subdesenvolvidas.

Para a teoria Neoliberal, os Estados são os principais atores das relações internacionais. Além disso, os atores não estatais são considerados relevantes para a compreensão das relações que se estabelecem no território, como as empresas multinacionais, organizações internacionais governamentais e não governamentais (OIGs e OINGs), partidos políticos, que, cada vez mais, estão construindo políticas externas próprias e independentes das políticas de seus Estados. O conceito básico corrente é de que a habilidade dos Estados de se comunicar e cooperar uns com os outros depende da construção de instituições, que podem variar em termos de suas naturezas e forças.

Waltz (1979, p.80) afirma que a estrutura da regulação política do território pelo mercado é definida pela forma com que as partes se arranjam (se posicionam), ou seja, a posição dos Estados uns em relação aos outros no 
sistema internacional é mais importante do que as características intrínsecas de cada um deles, como seu regime político ou a qualidade de sua liderança. O sistema internacional é definido em termos de sua estrutura, ou seja, a regra de posicionamento das unidades uma em relação às outras, mais o padrão de relacionamento entre as unidades.

Os mecanismos de regulação se fazem também pelas grandes corporações privadas. Na visão de Strange (1988), quatro são os pilares do poder das Relações Econômicas Internacionais: segurança, conhecimento, produção de bens e serviços e provisão de crédito e dinheiro, sendo a tecnologia (conhecimento) considerada como o grande impulsionador das mudanças estruturais da economia internacional. Assim sendo, os atos corporativos que controlam a pesquisa tecnológica acabam aumentando os seus pesos no sistema econômico internacional, ao mesmo tempo que os Estados vão perdendo poder na determinação das decisões econômicas.

Pela Teoria da Dependência (CARDOSO e FALETO, 1967) ${ }^{60}$, as empresas multinacionais têm o relevante papel de serem os grandes agentes entre os países centrais e os periféricos. A expressão mais clara do poder estrutural das empresas multinacionais em relação aos Estados está associada às decisões de entrada ou saída das empresas e à decisão de fechamento ou abertura de linhas de produção e serviços. Segundo Sarfati (2006, p.4), "a globalização impulsionada pela liberalização conduzida pelos Estados, o rápido desenvolvimento da tecnologia têm sofisticado a lógica da ação das empresas nas relações internacionais impulsionando dois fenômenos: a auto-regulamentação e o lobby transnacional (diplomacia corporativa)". À medida que essas empresas se expandem em seu processo de internacionalização, diversas empresas nacionais acabam desaparecendo em meio a processos de aquisição e fusão. Desse modo, o custo de ficar de fora da economia global é muito maior do que o custo da vulnerabilidade crescente.

A hipótese geral verificada por Sarfati ${ }^{61}$ permite ver a ação das grandes

60 CARDOSO;FALETO,1967, apud SARFATI ,2006, p.22.

61 SARFATI, Gilberto. O terceiro xadrez: como as empresas multinacionais negociam nas relações econômicas internacionais. Faculdade de Filosofia, Letras e Ciências Humanas (FFLCH). Universidade de São Paulo. São Paulo.2006. 
empresas como independente e não submissa à ação dos Estados, ao mesmo tempo em que, aceita a centralidade da ação dos Estados na regulação do sistema econômico internacional. Nessa perspectiva, o autor argumenta que as empresas multinacionais buscam influenciar os Estados e suas coalizões utilizando-se de seu poder estrutural. Uma importante conclusão da tese de Sarfati é que "a influência das empresas multinacionais nas negociações econômicas internacionais depende largamente das estruturas dos processos de negociação, onde fóruns multilaterais e multitemáticos tendem a favorecer a influência das multinacionais em comparação a fóruns monotemáticos" (SARFATI, 2006,p.12).

A emergência dos projetos e planos estratégicos contemporâneos no mundo tendem a acompanhar o surgimento dos discursos sobre a atração de capitais tecnológicos, como forma de garantir e sustentar o desenvolvimento local indica uma perspectiva da ampliação da escala geográfica tomada por referência nas decisões sobre as políticas para os territórios. Esssa mudança vale-se da asserção de um contexto de novas transformações sobre o tecido urbano, sujeito ao processo de formação de um espaço globalizado que articula os lugares pela disposição extensiva de infraestruturas de transporte e comunicação.

No Brasil, por conta de experiências bastante controversas, o que as versões do planejamento dito "estratégico" possuem em comum é a explicitação da dimensão política do planejamento, como identificação dos grupos de interesse envolvidos, análise de conjuntura, entre outros, com o objetivo de tentar costurar alianças e/ou de promover uma visualização mais clara das ameaças, das potencialidades e dos obstáculos presentes. Em geral, isso é feito de modo acrítico e as alianças são condicionadas por um viés que é o peso enorme dos interesses empresariais na definição da agenda. $\mathrm{Na}$ verdade, muito pouco resta em matéria de discurso sobre o interesse público, no mais das vezes, o planejamento pautado pela aliança público e privado busca convencer que o favorecimento dos interesses empresariais, gera crescimento econômico e traz benefícios coletivos como a geração de empregos e a maior circulação de riquezas. O referencial político-filosófico é conservador corresponde, em linhas gerais, ao ideário neoliberal, mundialmente hegemônico desde os anos de 1980. 
Teoricamente, a influência das empresas multinacionais sempre se dá dentro do marco nacional, ou seja, o Estado é que caracteriza o ativo econômico-político dessas empresas para o seu próprio interesse e, na medida em que convenha a sua agenda, retorna às empresas, promovendo sua expansão internacionalmente. Em última instância, poderíamos dizer que, quanto mais um Estado concentra empresas fortes no cenário internacional, maior será a influência econômica e política desse Estado. O Estado, seria, assim, sinônimo de organizações corporativas, o que aponta para uma clássica privatização do público. Nessa perspectiva, a abordagem sobre as parcerias públicas e privadas no âmbito local se faz necessária, de modo a favorecer a compreensão das mediações entre as determinações globais e locais na produção do espaço.

No panorama em que se realiza o planejamento estratégico de longo prazo do estado do Espírito Santo, vale ressaltar a aliança nas ações estabelecidas entre o movimento empresarial "O Espírito Santo em Ação" e o Governo do Estado. O "ES em Ação" está estruturado para operar em sistemas de rede que possibilita a integração de elementos e instituições autônomas num plano horizontal, com ações de cooperação que possam ser acionadas em redes de diferentes cortes, abrangências territoriais e dimensões. O ES em Ação tem como missão "mobilizar a classe empresarial do ES a contribuir na formação de uma sociedade melhor e mais justa." E apresenta como "visão" "ser reconhecido como referência do pensamento empresarial capixaba e agir como um importante catalisador de interesses originários de setores empresariais, através de ações positivas e pró-positivas, colocando-se como instância de representação qualificada do empresariado" (ESTATUTO do ES em Ação, 2008) ${ }^{62}$.

O Movimento Empresarial do Espírito Santo estabelece ainda que atuará como "catalisador de idéias, organizador de debates e condutor de projetos e ações públicas que visem ao desenvolvimento do Estado”. É importante frisar que as empresas mais representativas do Estado estão engajadas nesse processo, justamente no intuito de criar um pacto e demonstrar a força empresarial junto às instituições públicas e outros setores da sociedade na defesa de seus interesses. Entre as empresas mais fortes, no estado

62 Estatuto ES em Ação. Disponível em < http://www.es-acao.org.br/esemacao/esemacao/ estatuto/estatuto.php>. Acesso em jun 2008. 
que integram o ES em Ação, temos: a Vale, a Aracruz Celulose, a Arcelor Mittal (siderurgia); a Samarco Mineradora; a Rede Gazeta, a Rede Tribuna (empresas de comunicação, jornal e TV); a Viação Itapemirim e o Grupo Águia Branca ( transporte rodoviário); o Grupo Tristão (exportação de café); a Chocolates Garoto; a ESCELSA (energia elétrica); a FAESA (Faculdades associadas); a Coca-Cola; a Oi; a Elkem; entre outras.

Analisando o Estatuto Social do "ES em Ação", observa-se que algumas de suas finalidades comprovam a tese de que as relações entre Estado e empresas estão atreladas de modo irrefutável à consolidação dos interesses de mercado, a saber: "ser indutor de mudanças nas relações entre o setor público e o setor privado, garantindo a transparência e a ética, bem como a ambiência adequada ao desenvolvimento das empresas e da sociedade; contribuir para a formação de lideranças empresariais e políticas capazes de promover a construção das condições para o desenvolvimento sustentável; apoiar e promover ações que busquem reconstruir a credibilidade do setor público estadual e restauração da confiança interna e externa, principalmente junto aos investidores; promover o acompanhamento das ações dos Poderes Executivo, Legislativo e Judiciários estaduais e adotar ações concretas no sentido de permitir a continuidade de projetos públicos, eventualmente não priorizados em função das alternâncias governamentais" ${ }^{33}$ [grifo nosso].

Fundamentalmente, o interesse das grandes empresas capixabas está ligado à sua sobrevivência dentro do jogo dos negócios internacionais associada a estratégias que garantam lucro, não só no ano fiscal corrente, mas também no longo prazo. Isso não se faz sem uma regulação política do território pelo mercado. Para que as metas do planejamento estratégico se viabilizem, as empresas pactuam com o Estado o interesse em fomentar recursos no desenvolvimento de projetos e infraestruturas. É desse modo que se reconstroem os contextos da evolução das bases materiais geográficas e também da própria regulação, haja vista o fato de que o "ES em Ação" foi o interlocutor do Estado na contratação dos estudos para Avaliação Ambiental Estratégica (AAE) do Polo Industrial e de Serviços, além de participar efetivamente na produção de diagnósticos e estudos

63 Estatuto ES em Ação. Disponível em < http://www.es-acao.org.br/esemacao/esemacao/ estatuto/estatuto.php>. Acesso em jun 2008. 
que indiquem novos vetores de expansão dos circuitos produtivos. Essa condição de inserção direta nos assuntos de interesse público evidencia a interdependência entre o público e o privado na condução das políticas territoriais no estado do Espírito Santo.

Diante do exposto, observa-se que o que está em jogo não é apenas a realização de intervenções lastreadas em uma análise da realidade social e espacial codificada em relatórios e diagnósticos, mas a captação de sinais emitidos e solicitados pelo mercado ou, simplesmente, o atendimento de demandas específicas, predefinidas, relativas ao interesse do capital industrial, imobiliário e outros segmentos empresariais. Nesse contexto, é lógico que o grau de abertura para com a participação popular restringir-se-á, na melhor das hipóteses, às formas de pseudoparticipação, às vezes, não chegando sequer a isso. 
138| CAṔ́TULO 3 


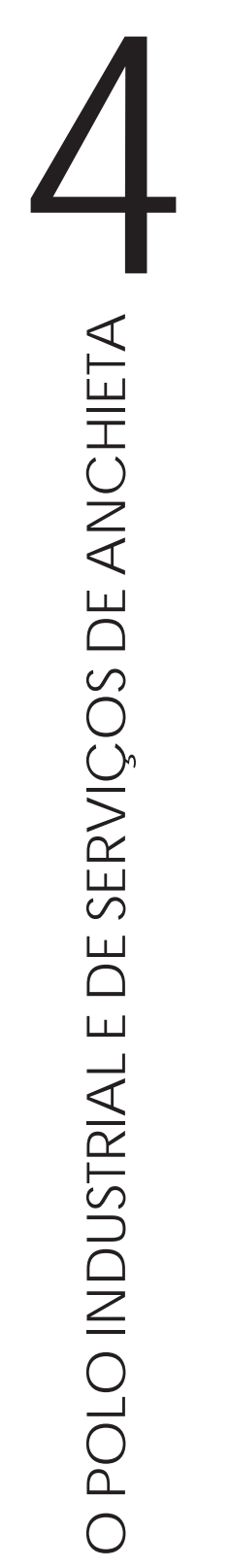

Todo planejamento traz, subjacente, uma concepção de vida social e, de certa forma, uma utopia em que alguns aspectos e configurações são valorizados em detrimento de uma infinidade de outras possibilidades [...] ao projeto e ao plano cabe, neste momento histórico, o papel de transcender a racionalidade, de revelar, na construção da paisagem, a pluralidade e a diversidade sociais sem suprimir os conflitos e, principalmente, sem neutralizar oposições.

Leite (2004a, p.67) 
140| CAPÍTULO 4 


\section{O POLO INDUSTRIALE DE SERVIÇOS DE ANCHIETA}

Entre os projetos constantes da carteira de Projetos Estruturantes do Plano 2025, temos aqueles que balizaram a criação do Pólo Industrial e de Serviços de Anchieta, fornecendo suas bases estruturais e suas diretrizes, a saber: o projeto de "Implantação do Polo Siderúrgico em Anchieta" (projeto de no 61 do grupo Agregação de Valor à Produção, Adensamento das Cadeias Produtivas e Diversificação Econômica); o projeto de "Desenvolvimento do Porto de Ubu" e a criação da "Ferrovia Litorânea Sul" (projetos 70 e 76, respectivamente, do grupo Desenvolvimento da Logística) e ainda o projeto "Desenvolvimento Urbano de Anchieta e Região de Impacto" (dentro do Grupo "Desenvolvimento da Rede de Cidades").

O governador do Espírito Santo, Paulo Hartung, no uso de suas atribuições, cria o Polo Industrial e de Serviços de Anchieta por meio do Decreto Estadual $n{ }^{\circ} 1.247-\mathrm{S}$ em 10 julho de $2007^{64}$, portanto, posteriormente à data de aprovação do Plano Diretor Municipal de Anchieta - PDM (2006). O governo desapropriou por meio desse decreto uma área de 2,5 mil hectares (25 milhões em metros quadrados), correspondente a dez propriedades particulares, para a sua implantação. Este é o primeiro grande distrito industrial fora dos limites da Grande Vitória que deverá abrigar atividades siderúrgicas, mineradoras, de petróleo e gás, além da estrutura logística portuária e ferroviária.

O referido Decreto justifica a criação do Polo Industrial e de Serviços de Anchieta com base nos seguintes argumentos considerados em seu caput.

- $\quad$ é atribuição do Estado regular e fomentar as atividades econômicas objetivando a redução das desigualdades sociais e regionais e o incremento de empregos diretos e indiretos;

- o Estado do Espírito Santo em conformidade com o "Plano de Desenvolvimento Espírito Santo 2025" tem pautado seu desenvolvimento na atração de investimentos produtivos, salientando a importância da interiorização do investimento, a inserção regional e a conservação dos recursos naturais;

- cabe ao Estado estimular a manutenção e o desenvolvimento de empreendimentos 
industriais, bem como a orientação e apoio à localização racional de novos estabelecimentos e à relocalização dos existentes;

- Em referência ao seu Plano de Desenvolvimento, a economia capixaba deverá apresentar uma trajetória de diversificação da estrutura produtiva local, resultante de longo processo de adensamento e agregação de valor das principais cadeias produtivas instaladas;

- A criação de um polo industrial e de serviços terá atuação relevante no desenvolvimento econômico do Estado do Espírito Santo;

- A posição estratégica do local escolhido para a implantação do polo industrial e de serviços possibilitará acesso viário, ferroviário e portuário;

- A área em questão encontra-se destinada pelo Plano Diretor Municipal do Município de Anchieta para fins industriais;

- O polo será implantado pela Superintendência dos Projetos de Polarização Indus-

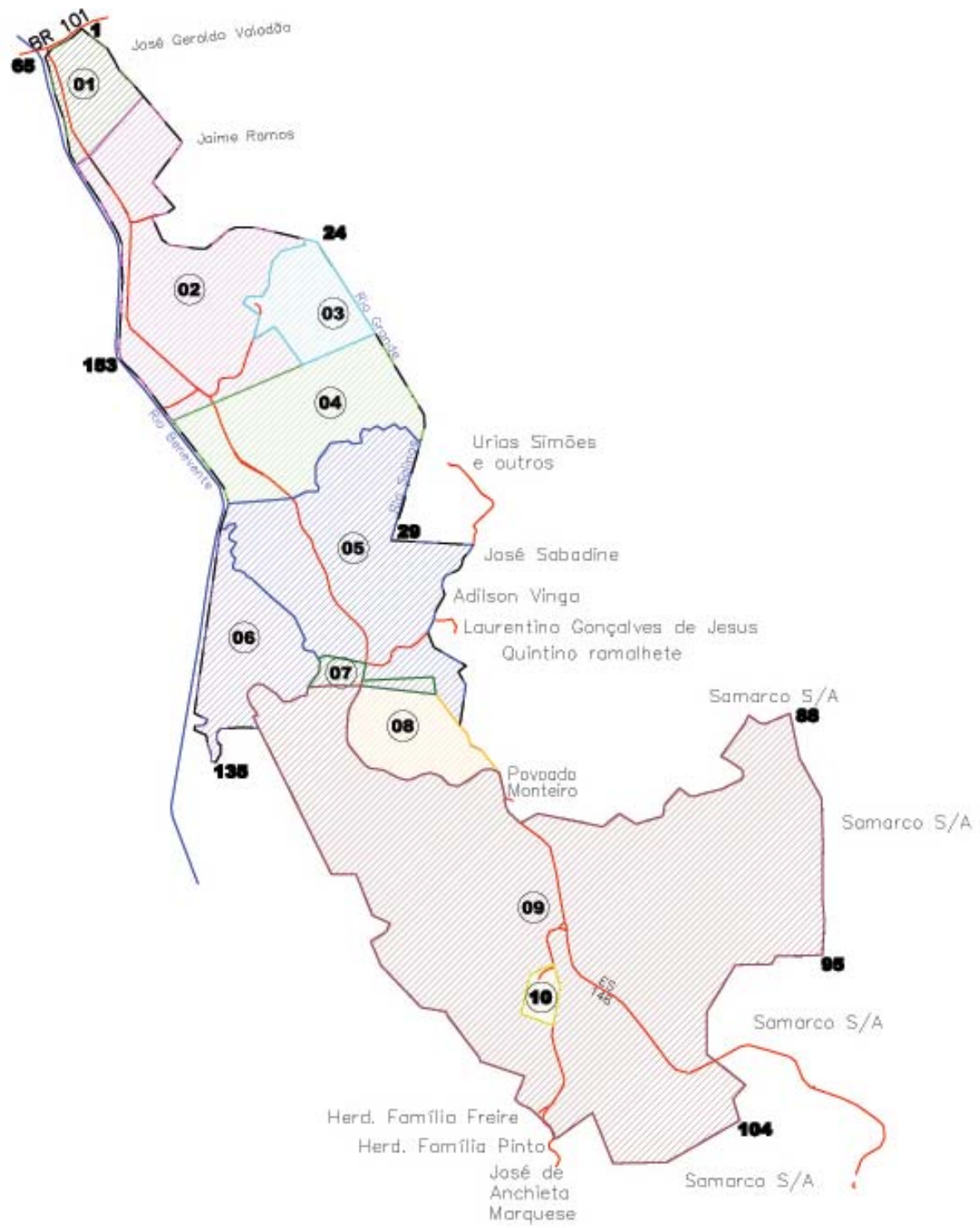

FG.23

Mapa da Zona Industrial do Pólo mostrando as propriedades particulares que foram desapropriadas pelo Estado para implantação dos projetos. Fonte: PDM de RG.23 Anchieta 
trial - SUPPIN, autarquia responsável pela viabilização no Estado de Polos Industriais, que se encontra hoje com seus mais importantes polos sem capacidade para abrigar projetos industriais de grande porte;

- Considerando, finalmente, ser sempre possível a desapropriação de bens particulares, quando se verificar pressupostos constitucionais da utilidade pública.

(DECRETO N 1247-S, de 10 de julho de 2007)

O decreto segue elencando as áreas de terras rurais e as respectivas benfeitorias porventura existentes sobre as mesmas declaradas de utilidade pública. Toda essa estrutura está respaldada pelo poder público nas duas instâncias de poder, o Plano 2025 e o Plano Diretor Municipal de Anchieta, conforme explicita o referido decreto: “o governo do Estado declarou de Utilidade Pública para fins de desapropriação uma área de 2.536,37 hectares no município de Anchieta, destinada à criação do Pólo Industrial e de Serviços de Anchieta, em sintonia com o Plano Diretor do Município de Anchieta e do Plano de Desenvolvimento ES 2025" (Figura 22). No decreto consta ainda que "os investimentos potenciais para a região e as manifestações de interesses empresariais para implantação de projetos dos segmentos de siderurgia, metal-mecânica, petróleo e gás, infra-estrutura portuária e ferroviária, dentre outros, devem estar coordenados de forma a garantir a agregação de valor e um avanço no processo de descentralização da economia capixaba" ${ }^{65}$.

A elaboração do Plano Diretor do Polo considerou a necessidade de integração econômica regional, assim como a localização privilegiada de Anchieta para a implantação de um complexo industrial, por já possuir infraestrutura rodoferroviária e portuária, mesmo que ainda de capacidade reduzida. Com relação à localização no contexto estadual, especificamente, vale destacar alguns dos aspectos considerados importantes para a instalação do Polo e a escolha do lugar, condições e vocações estratégicas para a implantação do empreendimento, a saber:

- região privilegiada na costa do Espírito Santo para um porto de águas profundas;

- vocação para o comércio exterior tendo em vista a capacidade já ins-

65 Fonte: GOVERNO DO ESTADO DO ESPÍRITO SANTO. Decreto Estadual n ${ }^{\circ}$ 1.247-S- 7 de julho 2007 
talada da Samarco

- Mineradora no municio de Anchieta;

- saturação da região Metropolitana de Vitória para grandes projetos;

- dinamizar o desenvolvimento da região sul do Estado;

- necessidade de agregar maior valor a produtos dirigidos à exportação.

$\mathrm{Na}$ proposição do Polo, outros condicionantes infraestruturais também foram levados em consideração ${ }^{66}$ :

- a necessidade de compatibilização das ligações viárias locais, municipais e regionais atuais e futuras, com as vias propostas pelo Plano Diretor Municipal;

- a existência de linhas de transmissão e subestações, do gasoduto e da ferrovia projetada, que apresentam interferência na área do Pólo;

- a construção da Unidade de Tratamento de Gás (UTG) e o traçado do ramal do gasoduto (Gasene).

\subsection{Localização e área de influência}

O Polo Industrial de Anchieta localiza-se no município de Anchieta, ao sul da Região Metropolitana da Grande Vitória, especificamente na Microrregião Expandida Sul, composta pelos municípios de Anchieta, Alfredo Chaves, Iconha, Piúma, Itapemirim e Marataízes. O Polo encontra-se inserido na Zona de Expansão Industrial (ZEI 1) do Plano Diretor Municipal de Anchieta (Lei no 013/2006) ${ }^{67}$, destinada ao uso predominantemente industrial de médio e grande porte, de apoio logístico e de suporte aos grandes empreendimentos e de atividades retroportuárias. Em sua área, alternam-se alguns trechos de AEIA - Áreas Especiais de Interesse Ambiental, constituídas pelos ambientes naturais ou paisagísticos de interesse para a preservação, conservação, recuperação e/ou desenvolvimento de atividades sustentáveis. Com relação aos aspectos topográficos da área diretamente afetada, e de influência direta e indireta do Pólo e região, verifica-se um relevo complexo, com variações desde o nível do mar até elevações de $1.000 \mathrm{~m}$ de altitude. No entanto, na área demarcada do Polo,

66 Fonte: ES EM AÇÃO. Pólo Industrial e de Serviços de Anchieta. Avaliação Ambiental Estratégica - AAE. Vitória. .2008 pg.30 e 31

67 O Plano Diretor Municipal de Anchieta será tratado num capitulo específico.

\section{HG.24}

Pólo Anchieta e sua inserção geográfica no Espírito Santo. Fonte: Acervo pessoal

HG.25

Localização do Pólo em relação ao Macrozoneamento estabelecido pelo PDM de Anchieta 


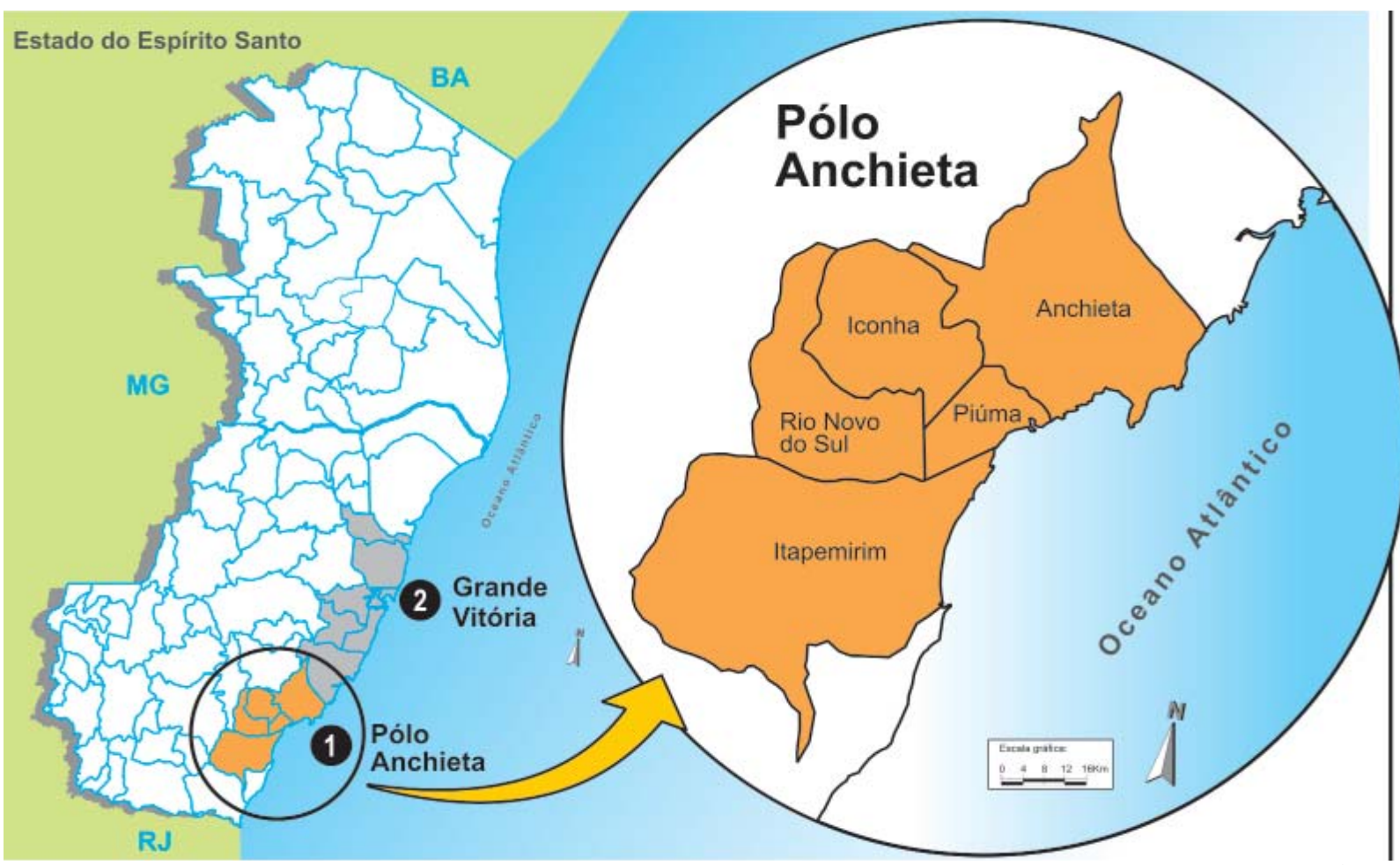

FG.24

MIE - MACROZONA INDUSTRIAL E DE EXPANSÃO MUMR - MACROZONA DE USO MULTIFUNCIONAL RURAL

MU - MACROZONA URBANA

AEIA - AREAS DE ESPECIAL INTERESSE AMBIENTAL

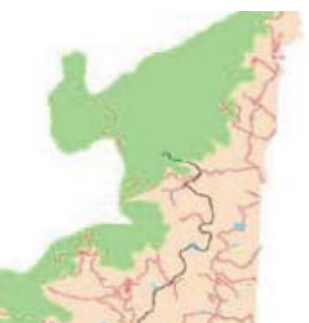




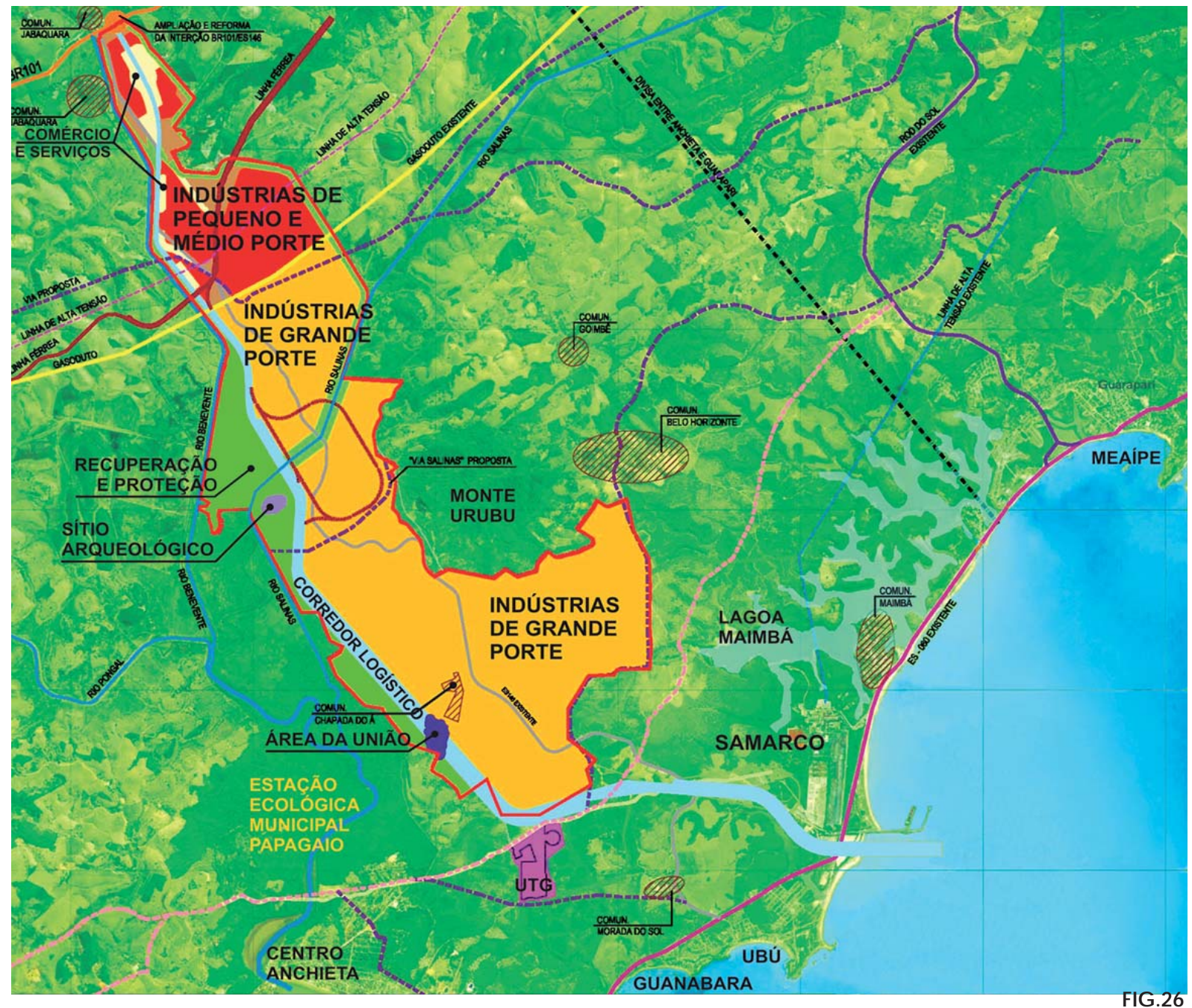

o relevo é predominantemente plano, com ondulações suaves.

RG.26

Desenho do pólo e respectivo zoneamento Fonte: Aderes - 2008 / Os municípios diretamente afetados são Anchieta, Guarapari e Piúma. Outros municípios mais próximos também receberão algum tipo de imgenio pacto (área de impacto secundário), pois são integrantes da bacia do rio Benevente, do eixo da BR 101 e da Ferrovia Variante Litorânea Sul, que fará a ligação entre Santa Leopoldina e Cachoeiro de Itapemirim, passando por Vitória e pelo Porto de Ubu. Nesse sentido, a área de influência do Polo se estenderá aos municípios de Alfredo Chaves, Cachoeiro de Itapemirim, Iconha, Itapemirim, Marataízes, Presidente Kennedy, Rio Novo do Sul e Vargem Alta. A influência gerada nessas regiões está relacionada à instalação e à utilização de logística adequada para atender aos investimentos do Pólo Industrial, à atração de mão de obra para as regiões circunvizinhas ao Polo, dado o aumento considerável da oferta de trabalhos temporários (em fase de instalação dos investimentos) e de empregos fixos 
Tábela 10

Projetos vinculados ao Polo Anchieta

\begin{tabular}{|c|c|c|c|c|}
\hline Projetos & Até 2010 & Até 2015 & Até 2020 & Até 2025 \\
\hline Samarco: Terceira Pelotização & Alta & - & - & - \\
\hline Refinaria de petróleo & Ba ixa & Ba ixa & Baixa & Baixa \\
\hline $\begin{array}{l}\text { Exploração de Petróleo e Gás e atividades } \\
\text { correlatase Royalties }\end{array}$ & Alta & - & - & - \\
\hline Ferrovia Litorânea Sul & Média & Alta & - & - \\
\hline $\begin{array}{l}\text { Diversificação do Porto de Ubu e instalação do } \\
\text { centro empresarial }\end{array}$ & Média & Média & Alta & - \\
\hline Novo Pólo Siderúrgico & Baixa & Média & Média & Média \\
\hline $\begin{array}{l}\text { Instalação de negócios vinculados às } \\
\text { potencialidadeslocais }\end{array}$ & Média & Média & Média & Média \\
\hline Lógica da expansão da Metropóle & Baixa & Média & Alta & - \\
\hline
\end{tabular}

(em fase de operação dos empreendimentos); à utilização de recursos naturais; à disposição dessas cidades em alojar trabalhadores do Polo, com o intuito de movimentar sua economia e aumentar sua arrecadação. Esses municípios receberão impactos menores, porém não menos relevantes, no que diz respeito a mudanças sociais geradas pelo incremento populacional ou mesmo pela maior circulação de pessoas e mercadorias.

\subsection{Desenho conceitual do pólo}

O Polo Industrial terá na atividade siderúrgica o seu empreendimentoâncora, podendo integrar-se a outros empreendimentos. As características peculiares dessa atividade requerem ligações específicas destinadas ao fornecimento direto de insumos e matérias-primas e requerem também operações de saída dos produtos finais, além de outros empreendimentos que sejam julgados essenciais para a sua operação. Os projetos que compõem o Polo Industrial de Anchieta e/ou propostos nas áreas contíguas de apoio logístico, basicamente são:

\section{- Siderurgia e atividades industriais:}

a.instalação de uma usina siderúrgica para produção de placas de aço: produção 10 milhões t/ano de aço;

b.instalação de uma fábrica de bentonita (Bentonit União Nordeste 
Ltda): aglomerante do processo de pelotização e do processo de perfuração para extração de petróleo: produção de 200 mil t/ano;

c. indústrias do setor metalmecânico e de suporte ao setor siderúrgico e de petróleo e gás;

- Desenvolvimento do Porto de Ubu: O objetivo da ampliação do porto é que ele dê sustentação para as empresas que se instalarão no novo pólo industrial. O projeto da Vale é construir um porto com calado suficiente para receber navios de grande porte, o que exige uma profundidade maior no acesso ao porto. O projeto prevê a construção de três berços que permitirão 450 atracações por mês.

- Ferrovia Litorânea Sul (projetos 70 e 76, respectivamente, do grupo "Desenvolvimento da Logística"). A Ferrovia Litorânea Sul está em fase de estudo e é a denominação dada à Variante Ferroviária Cariacica - Cachoeiro de Itapemirim. O projeto da ferrovia prevê 150 quilômetros de malha ferroviária ligando Vitória ao município de Cachoeiro do Itapemirim, projetada próxima ao litoral, ao lado da BR-101. Este é um projeto antigo do governo estadual, que tem a intenção de substituir o trecho montanhoso da antiga Estrada de Ferro Leopoldina, além de desafogar o trânsito de caminhões da BR 101 no eixo sul. Com a ferrovia em funcionamento, os embarques de mármore e granito provenientes de Cachoeiro de Itapemirim seriam transferidos para o Porto de Ubu, em Anchieta. Para atender à Samarco, também em Ubu, seria construído outro ramal de 16 quilômetros em parceria com a Companhia Vale do Rio Doce (CVRD).

- Mineroduto UTG Sul (Unidade de Tratamento de Gás da Petrobras): produção de 5 milhões de m3/dia; $\mathrm{O}$ gás produzido nos campos de exploração de petróleo de Jubarte, Cachalote, Anã, Azul, que vem com óleo pesado, será processado na UTG sul, que está em fase de construção em Ubu- Anchieta.

- Ampliação da SAMARCO ${ }^{68}$ Mineração: A empresa expandiu sua

68 A Samarco Mineração é uma empresa de lavra, beneficiamento, transporte, pelotização e exportação de minério de ferro, cujas instalações industriais estão localizadas em dois Estados: em Minas Gerais, nos municípios de Mariana e de Ouro Preto, situam-se as operações de lavra e beneficiamento de minério de ferro; e no Espírito Santo, em Anchieta, encontram-se a planta de pelotização e o porto, de onde a totalidade da produção é exportada. A Samarco tem capacidade 
capacidade de produção com o "Projeto de Terceira Pelotização", cujas obras foram concluídas no primeiro trimestre de 2008. Atualmente, estão em operação três usinas de pelotização. A Samarco planeja investir ainda um montante superior a US\$ 2 bilhões, a partir de 2010, destinado a projetos voltados para a expansão da produção e da logística no Espírito Santo e em Minas Gerais. O planejamento da empresa prevê uma nova unidade - a quarta usina de pelotização -,totalizando um volume de produção de 29 milhões t/ano, podendo ser utilizado gás natural nas 4 usinas.

\section{- Desenvolvimento Urbano de Anchieta e Região de Impacto} (dentro do Grupo "Desenvolvimento da Rede de Cidades"). O projeto possui como objetivo a descentralização dos investimentos econômicos da região metropolitana, com a expansão desses investimentos para as demais regiões do Estado, conforme já apresentado no capítulo 3 desta tese.

Para viabilizar tais investimentos, foi projetada uma via de serviços, denominada Corredor Logístico, com 17,5 km de extensão, que interliga a BR101 à Rodovia do Sol, alterando o atual traçado da ES146 (Figura 27). Nesse corredor, estão concentradas as principais redes de utilidades, organizando a distribuição dos serviços e atividades ao longo da área que limita o Polo na direção sul, bem como no seu entorno imediato. Os possíveis segmentos da atividade industrial e atividades correlatas a serem instalados estariam subordinados às áreas previamente definidas de acordo com a escala: empresa de pequeno, médio e grande porte. Assim, as áreas ou macrozonas foram distribuídas conforme as tendências das necessidades de localização e do porte das atividades, os usos, a logística e os fluxos, as distâncias entre os elementos fixos e os condicionantes naturais.

Alguns aspectos possuem relevância para a definição do impacto relativo ao desenho do Polo Anchieta, tais como o seu tamanho (25 milhões em metros quadrados) e, principalmente, o que se refere à localização do em-

instalada para produzir e comercializar 14 milhões de toneladas/ano de pelotas de minério de ferro e 1 milhão de toneladas/ano de finos de minério (pellet feed e sinter feed). Seus recursos minerais são da ordem de 4 bilhões de toneladas, que asseguram o suprimento de minério de ferro por pelo menos 50 anos, ao ritmo de produção atual.. A empresa possui um dos maiores minerodutos do mundo para transporte de minério de ferro, com $396 \mathrm{~km}$ de extensão, utilizado para transportar a polpa de minério de ferro entre suas duas unidades industriais. Fonte: SAMARCO Mineração. Relatório 2007. Disponível em <www.samarco.com.br> Acesso em abr. 2008. 
preendimento. Observa-se que mais de 30\% da área do Polo Industrial está diretamente conectada ou contígua às áreas de proteção legal, o que enseja uma atenção maior a ser dispensada a esse aspecto, principalmente em função das definições de uso e ocupação do solo, estabelecidas pelo Plano Diretor Municipal de Anchieta (PDM). Em virtude da importância e abrangência de um projeto como o Polo e das situações conflitantes que se delineiam em termos do uso dos recursos e da proteção ambiental, o Governo do Estado solicitou a Avaliação Ambiental Estratégica(AAE) ${ }^{69}$ para elaboração de estudos e avaliação das consequências ambientais de sua implantação, dos impactos positivos ou negativos e da sustentabilidade dos recursos naturais, de acordo com a abrangência, os procedimentos e os critérios gerais estabelecidos.

\subsection{Plano Diretor Munic ipal respalda o Polo?}

Ao nos debruçarmos sobre a tarefa de investigar a implantação do Polo num município de grande diversidade histórico-cultural e ambiental, um desafio que se coloca de imediato é o de realizar um esforço de imaginação do futuro e pensar cenários desejados. Como argumenta Matus "se não pensamos ou planejamos, somos escravos da circunstância e negar o planejamento é negar a possibilidade de escolher o futuro, é aceitá-lo seja ele qual for"(MATUS,1996, p.14). Não deve haver sombra de dúvida quanto ao fato de que o planejamento necessita ser referenciado por uma reflexão prévia sobre os desdobramentos do quadro atual - ou seja, por um esforço de prognóstico. Não há ação, muito menos ação coletiva coordenada que possa prescindir disso. Anchieta é, hoje, foco de atenção das redes técnicas e informacionais, no momento de retomada industrial no Espírito Santo com a criação do Polo Industrial e de Serviços. Nesse contexto, a situação do município de Anchieta, assim como de toda a Microrregião Metropolitana Expandida Sul, é promissora no contexto econômico, dado que investimentos de grande porte foram anunciados recentemente e outros estão em fase de estudo.

$\mathrm{Na}$ perspectiva analítica das condições que viabilizaram a concepção do Pólo Industrial, há que se fazer uma investigação dos instrumentos legais 
que, de certa forma, prepararam juridicamente e tecnicamente o território para respaldar os projetos vinculados a ele. Do universo dos instrumentos normativos aplicáveis aos processos que dizem respeito ao desenvolvimento econômico, à preservação das condições socioambientais, destacam-se os planos diretores municipais (PDM’s). O Plano Diretor Municipal é um instrumento de planejamento e uma obrigação explicitada no Estatuto da Cidade (Lei no 10.257/01), que tem por diretriz atender ao objetivo do desenvolvimento local, mas que, dentre outras circunstâncias, depende das condições físicas e de utilização social para que esteja em consonância com os princípios estabelecidos na Constituição Federal. Os inúmeros municípios do país tiveram que incluir essa exigência nas suas leis orgânicas. A Constituição Estadual garante que o Estado assistirá os municípios que o solicitarem, na elaboração dos planos diretores e, por ocasião da liberação de recursos do erário estadual e da concessão de outros benefícios em favor de objetivos do desenvolvimento urbano e social, o Estado atenderia, prioritariamente, ao município já dotado de Plano Diretor.

A experiência no Brasil com planos diretores demonstra a importância de se reconhecerem processos distintos de urbanização para construção de um marco jurídico que contemple realidades diversas com fins ao planejamento do uso do solo urbano. Apesar de se pressupor que todo Plano Diretor deva ter como premissa a conjugação de diversos horizontes com intuito de convergir para um desenvolvimento local equilibrado, há que se ressaltar a ocorrência de um mecanismo tecnicista que tende a replicar um mesmo modelo para todas as localidades. Assim, ao consolidar, numa mesma lei, a regulação tanto para novos parcelamentos do solo como para regularização destes, cidades com características distintas - históricas, geomorfológicas, econômicas - são tratadas da mesma forma, mesmo apresentando dinâmicas urbanas e passivos ambientais muito diferenciados. O caráter funcionalista do zoneamento convencional, em geral, incorpora a sua dimensão socialmente excludente e conservadora, a qual pode ser implícita ou, de certa forma, explícita.

Essa dissonância que se verifica entre os planos diretores e a realidade cotidiana se torna muito evidente quando a rebatemos no Polo Anchieta, especialmente se considerarmos que a própria legislação regulatória cria um fato controverso intrínseco a ela: o distrito industrial do Polo criado 
juridicamente compromete o meio físico e natural, especialmente a rede hídrica. O Plano Diretor Municipal de Anchieta (Lei no 013/2006), aprovado em 2006, já previa a instalação de uma zona industrial no município. Nessa época, quando o governo estadual ainda ensaiava a criação do Polo Industrial de Anchieta, os estudos do PDM indicavam que esse novo polo ou o distrito industrial teria capacidade para abrigar usinas de pelotização. A decisão estratégica do governador do Espírito Santo, Paulo Hartung, em não mais favorecer a construção de projetos de porte na Região Metropolitana da Grande Vitória fez deslocar o foco da indústria de mineração para o município de Anchieta, considerado pelo governo estadual como região ideal para sediar as grandes plantas industriais. A desapropriação do polígono que circunscreve a área industrial por decreto estadual consolida o Polo Industrial e de Serviços de Anchieta respaldado pelo poder público nas duas instâncias de poder: no Plano 2025 e no Plano Diretor Municipal de Anchieta.

Nos estudos realizados pela empresa contratada para formulação do Plano Diretor Municipal de Anchieta ${ }^{70}$, havia uma proposição inicial em que a área destinada à zona industrial seria bem mais restrita do que aquela aprovada pela legislação em vigor. Inclusive, os limites do perímetro urbano restringiam-se à porção do território sede onde a urbanização já estava praticamente consolidada. Em virtude da intenção manifestada pelas parcerias público-privada em ampliar o perímetro para incorporar a zona de expansão destinada ao uso industrial, teve-se que, então, proceder a um aumento considerável dos limites do perímetro urbano que em muito excedia a urbanização já consolidada.

Para se ter noção, em termos de valor de referência, do novo dimensionamento da linha perimetral urbana que em muito ultrapassa a anterior, procedemos às análises comparativas das áreas. A área do perímetro urbano válida anteriormente à aprovação da lei PDM/2006 perfazia um total de $29.975 .95 \mathrm{~m}^{2}$. A proposta técnica sugerida nos estudos do PDM era a de ampliar o perímetro apenas o necessário, de modo que pudesse incorporar a zona industrial requerida, e perfazia um total de 86.992.796. Entretanto, visando assegurar uma área ainda maior destinada à expansão da atividade

70 A empresa contratada pelo poder público foi a Espaço Arquitetura e Construção. 
industrial, o perímetro urbano aprovado pela lei do PDM em 2006 perfaz um total de $144.250 .896 .41 \mathrm{~m}^{2}$ (Figuras 28 e 29).

Com o intuito de planejar e gerir o esperado crescimento urbano de Anchieta para os próximos 20 anos e com base nas leituras técnicas e comunitárias, definiu-se o macrozoneamento do Plano Diretor Municipal de Anchieta. O macrozoneamento compreende todo o território municipal, englobando as áreas urbanas e rurais, conforme dispõe a Constituição Federal de 1988 e o Estatuto da Cidade (Lei no 10.257/01). Entre as suas diretrizes, uma delas visa estabelecer critérios que possibilitem a mesclagem de usos não conflitantes. O município foi subdividido em três macrozonas, que se diferenciam por suas características de dinâmica de desenvolvimento, seguindo as diretrizes estratégicas:

- Macrozona Multifuncional Rural: compreende as áreas de uso agrícola, extrativista ou pecuário, com áreas significativas de vegetação natural, com condições de permeabilidade próximas aos índices tolerados para as áreas de preservação ambiental; áreas de usos não agrícolas, como chácaras de recreio, lazer, turismo, indústrias e sedes de distritos.

- Macrozona Urbana(Art.38): compreende as áreas aonde devem ser induzidos o adensamento e a expansão urbana; é composta por áreas dotadas de infraestruturas, serviços e equipamentos públicos e comunitários e por áreas necessárias à expansão urbana.

- Macrozona Industrial e de Expansão (Art.39): é composta por áreas industriais de médio e grande porte, zona portuária, pequenos povoados com características socioculturais relevantes, vegetação natural, recursos hídricos e lacustres de significativo interesse, além de áreas de uso agrícola e pecuária com tendência à expansão do setor industrial. A Macrozona Industrial subdivide-se em duas zonas:

1. Zona Industrial Consolidada (ZIC): engloba áreas industriais da Samarco; área do Porto de Ubu.;

2. Zona de Expansão Industrial (ZEI): apresenta as seguintes características:

- proximidade com a zona industrial consolidada e a região 

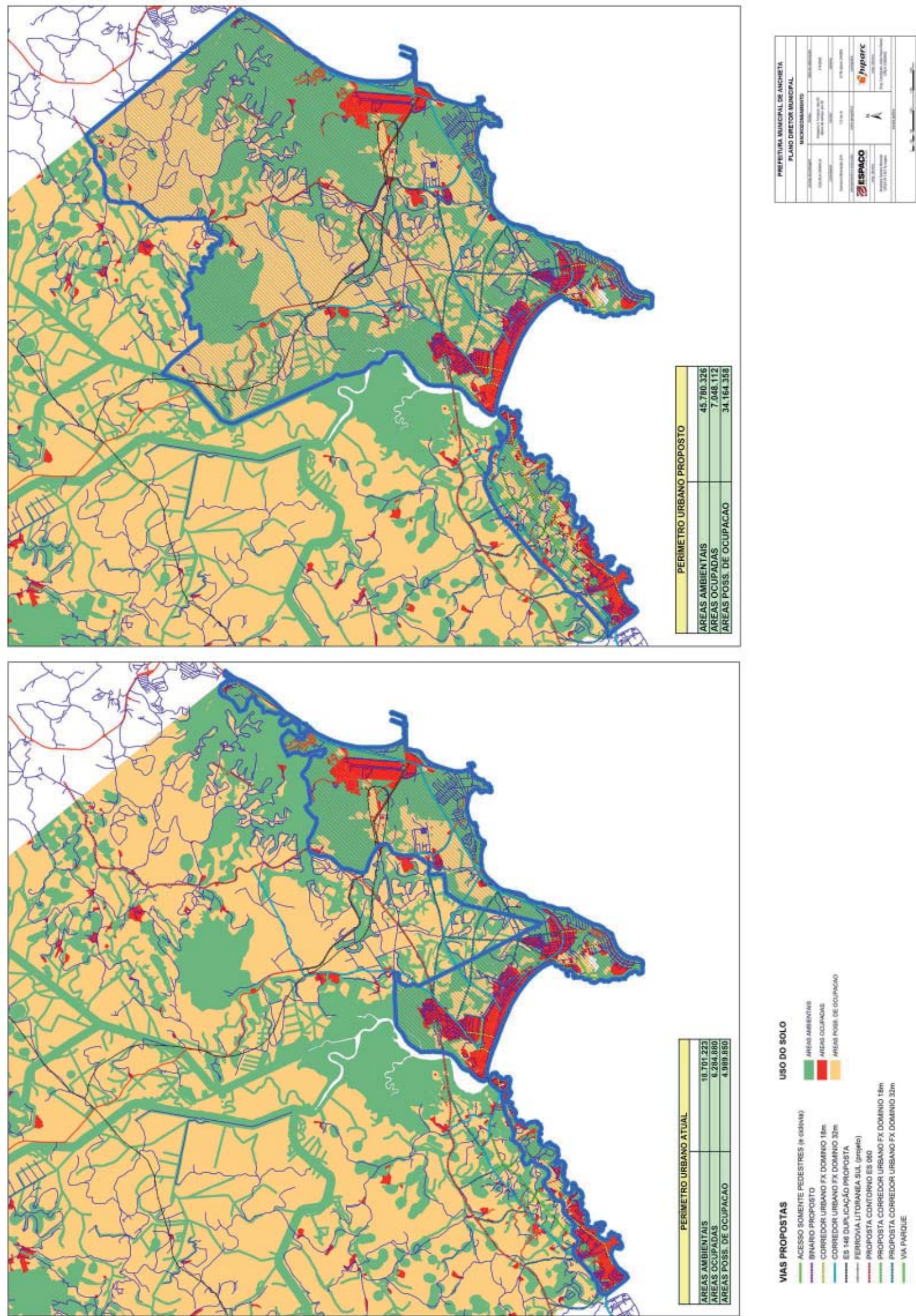

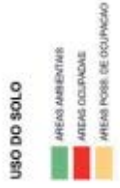

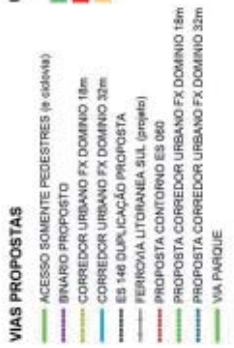

FG.27 
portuária;

- existência de grandes glebas;

- atendida pelas rodovias ES - 146 e BR - 101;

- localizada entre a faixa de proteção ambiental do rio Beneventes, a BR - 101, o limite do Município de Guarapari e da zona industrial consolidada.

Segundo Sandra Berredo, arquiteta responsável pela formulação do PDM de Anchieta, havia, nos primeiros estudos, a sugestão de criar uma Macrozona de Ocupação Negociada, como alternativa ao adensamento industrial, numa zona próxima a ecossistemas frágeis. O objetivo era assegurar ganhos para o município à medida que áreas para o uso industrial fossem demandadas por meio da outorga onerosa de mudança de uso ${ }^{71}$. O Plano Diretor pode definir áreas onde determinadas alterações de uso dos imóveis exigem pagamentos de contrapartida, mas não necessariamente. No caso de passagem de uso industrial para urbano, a contrapartida pode ser participação na implantação da infraestrutura/espaços protegidos/espaços coletivos previamente definidos no Plano Diretor Participativo. A proposta da Macrozona de Ocupação Negociada, conforme formulada inicialmente, se subdividia em duas zonas, conforme segue:

- ZON 1 - Zona de Ocupação Negociada 1: Área com tendência a mudança de uso de rural/urbano para uso industrial com a utilização da outorga onerosa de mudança de uso.

- ZON 2 - Zona de Ocupação Negociada 2: Área entre a ZUP e a ZON 1 para a localização preferencial de atividades não poluentes e de apoio e suporte à área industrial.

A despeito de interesses econômicos, tal proposta técnica não foi, entretanto, aceita, assim como também foi indeferida a proposta técnica elaborada pela empresa contratada, que previa uma grande área (zona) de

RG.27

Relativização do peńmetro urbano. À esq., a linha azul delimita o antigo peńmetro urbano vigente até 2006. À direita, o peńmetro proposto nos estudos do PDM, mas não aprovado. Fonte: Espaço Arquitetura e Construção amortecimento entre a macrozona urbana e a industrial. Não há dúvida de que as grandes empresas detêm um considerável poder no plano social,

71 A Outorga Onerosa do Direito de Construir e de Alteração de Uso refere-se à concessão emitida pelo Município para que o proprietário de um imóvel edifique acima do limite estabelecido pelo coeficiente de aproveitamento básico, mediante contrapartida financeira a ser prestada pelo beneficiário, cabendo à Administração Municipal destinar os recursos para atendimento às prioridades por ela.estabelecidas. 


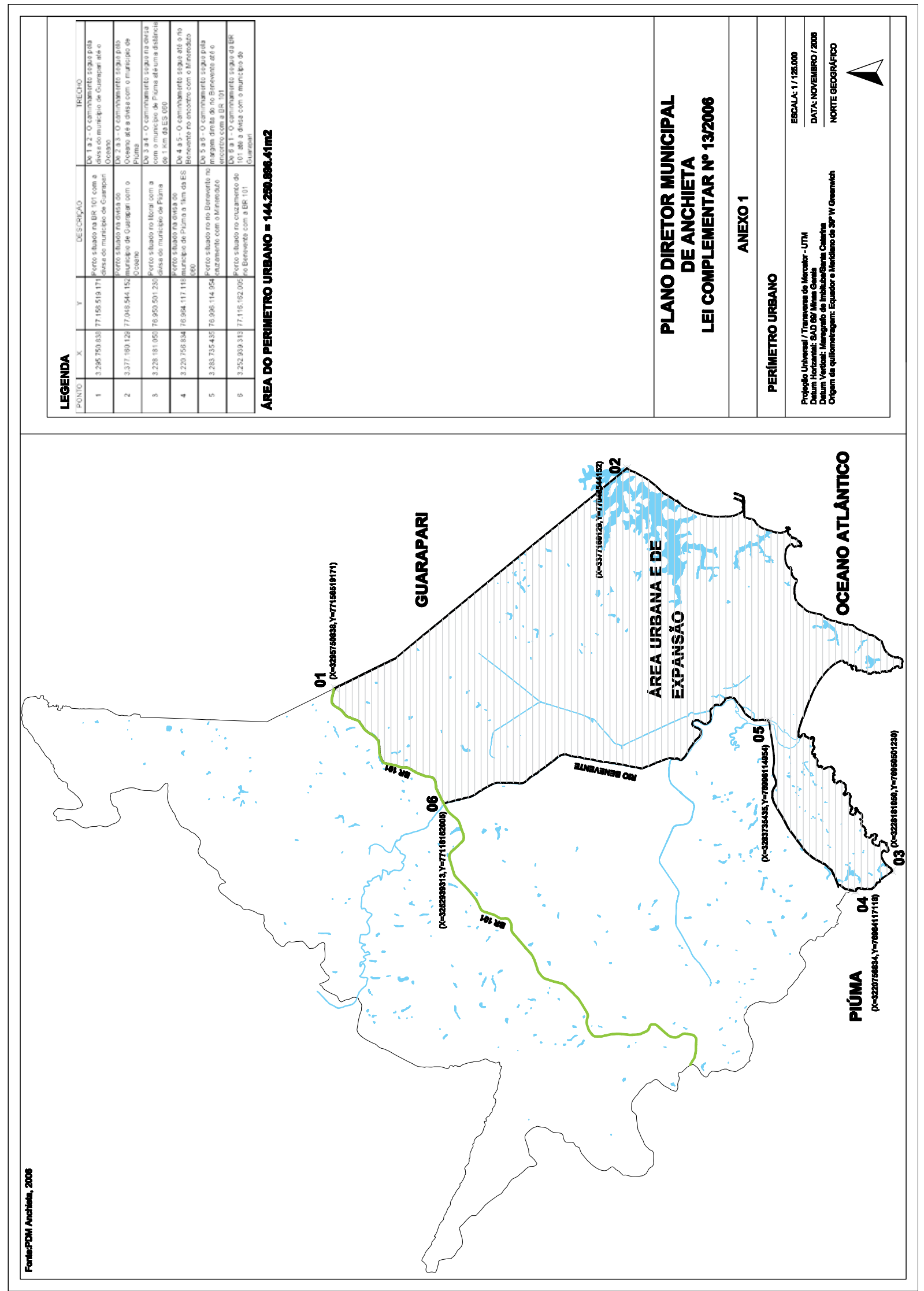

FG.28 
HG. 28

Perímetro Urbano atual de Anchieta. Fonte: Lei 013/2006 PDM pois controlam as formas de intervenção, no espaço social e no urbano, fundadas na técnica e no controle do aparelho de produção. Furtado argumenta: "O Estado numa sociedade de classes onde grupos concorrentes competem e quase sempre dividem de alguma forma o poder, constitui uma instituição mais complexa, de objetivos menos definidos e cambiantes, portanto, menos linear em sua evolução"(FURTADO,1996, p.68). Segundo o autor, essa debilidade do Estado como instrumento de direção e coordenação das atividades econômicas, em função de algo que se possa definir como o interesse da coletividade local, passa a ser um fator significativo na definição de cenários futuros.

O Artigo 65 da Lei PDM de Anchieta dispõe sobre as diretrizes da Zona de Expansão Industrial. Uma breve análise nos faz ver que a própria lei é incongruente em sua concepção, pois, ao mesmo tempo que estabelece zonas destinadas a implantar grandes projetos industriais, esforça-se por garantir, no mesmo artigo, as seguintes condicionantes ambientais:

- garantir a implantação de cinturão verde no entorno dos empreendimentos de grande porte;

- proteger os ecossistemas, as unidades de conservação, a fauna e a flora da região, mantendo o equilíbrio ecológico;

- garantir a análise pelos órgãos ambientais dos projetos de implantação das indústrias;

- minimizar os impactos ambientais;

- controlar e reduzir os níveis de poluição do ar, das águas e do solo.

Para as áreas de Especial Interesse Ambiental ( Figura 31) foram criadas três zonas:

- ZEIA 1 _ Áreas de Preservação Permanente (APPs);

- ZEIA 2 - Parques e Áreas de Proteção Ambiental;

- ZEIA 3 - Cinturão Verde.

Importante ressaltar que entre as diretrizes específicas do Plano Diretor concernentes à questão ambiental, temos as seguintes: preservar e recuperar as áreas de matas remanescentes e a vegetação ciliar; preservar a área formada por lagoas, córregos e matas e que não serão objeto de parcela- 
mento; criar parques próximos às áreas de preservação ambiental, com quadras de esportes, museus, centro de vivência e outras edificações educativas e recreativas; preservar as características históricas, socioculturais e do ambiente construído nos setores urbanos. Paralelamente a essas diretrizes de cunho ambiental, outras diretrizes foram estabelecidas no zoneamento, tais como estas: regulamentar a implantação de atividades terciárias de grande porte, de industriais e projetos complexos de ocupação; criar um cinturão verde entre a área industrial e a área urbanizada para reduzir os efeitos da poluição atmosférica (PDM, 2006).

Sobre as Áreas de Especial Interesse Ambiental (EIA1), o art. 86 do PDM dispõe, ressaltando entre elas:

- a Estação Ecológica Municipal do Papagaio;

- os manguezais do estuário do Rio Benevente;

- a Reserva Ecológica Restinga da Praia de Guanabara;

- a área das encostas rochosas à beira- mar, ao norte da Praia Costa Azul, e da encosta sul do Bairro São Jorge;

- a área ao redor das lagoas situadas na foz do córrego Iriri, Guanabara e Tanhurá, numa faixa de 50 metros contados da linha de nível médio das águas;

- a área ao longo do Rio Benevente, numa faixa de 100 metros, e dos Rios Alto Pongal e Salinas numa faixa de 50 metros.

- o Parque Lagoa Mãe-Bá, numa faixa de 100 metros contados da linha de nível médio das águas;

- o Parque Lagoa de Ubu, numa faixa de 100 metros contados da linha de nível médio das águas;

- o Parque Monte Urubu;

- o Parque Serra de Itaperoroma;

- a Reserva Serra de Jaqueçaba;

- o Parque Pico da Independência;

- as áreas consideradas como de preservação permanente, conforme legislação vigente.

- as unidades de preservação que vierem a ser criadas.

Sobre as AEIA2 e AEIA3, a Lei 013/2006, em seu art. 88, assim dispõe:

\section{FG.29}

Mapa Plano Diretor Municipal de Anchieta com respectivo zoneamento do município. Fonte: Lei 013/2006 PDM (formato A3)

RG.30

Mapa Plano Diretor Municipal com respectivas Zonas de Especial Interesse Ambiental. Fonte: Lei 013/2006 PDM (formato A3) 


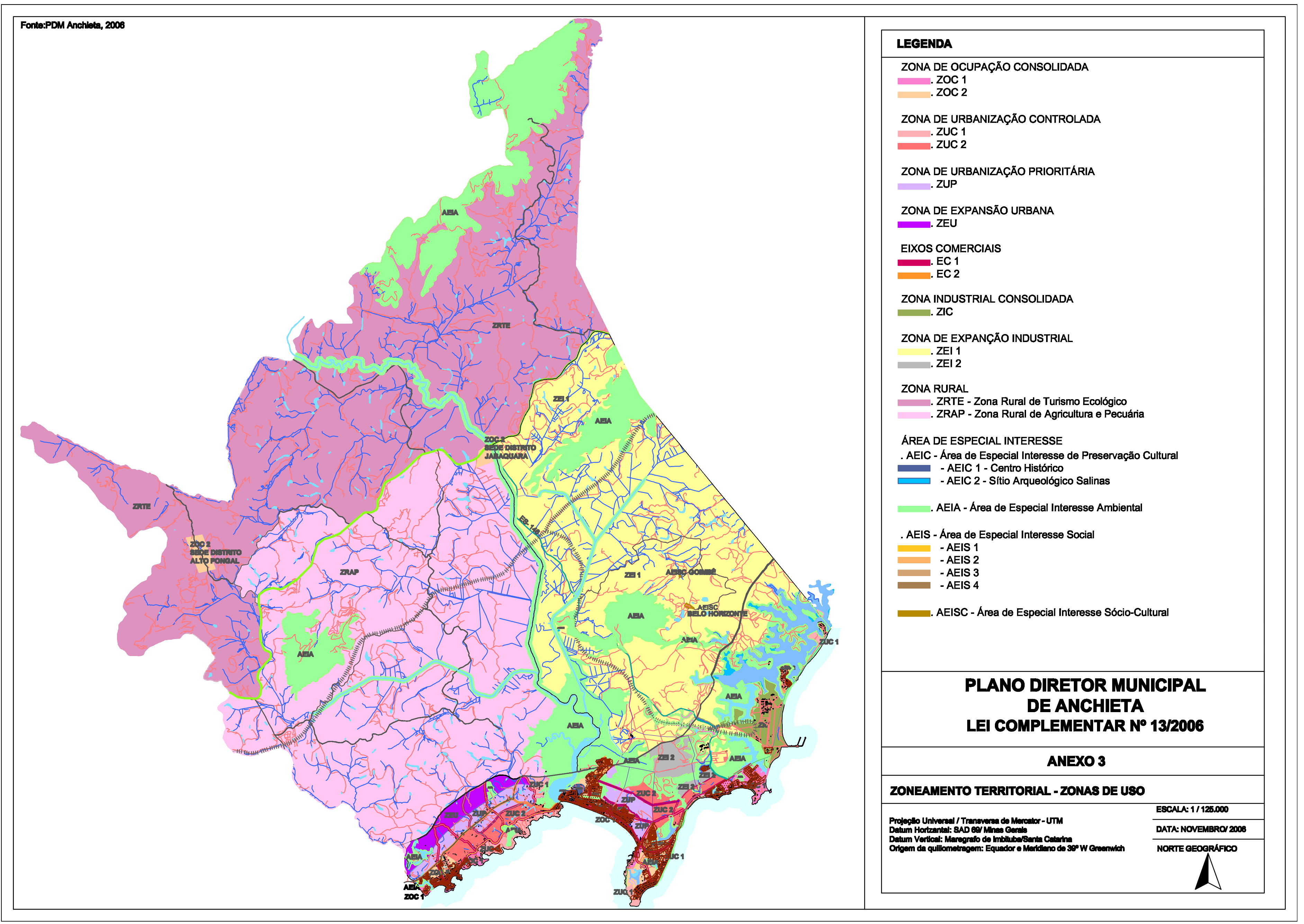


160| CAṔ́TLLO 4 


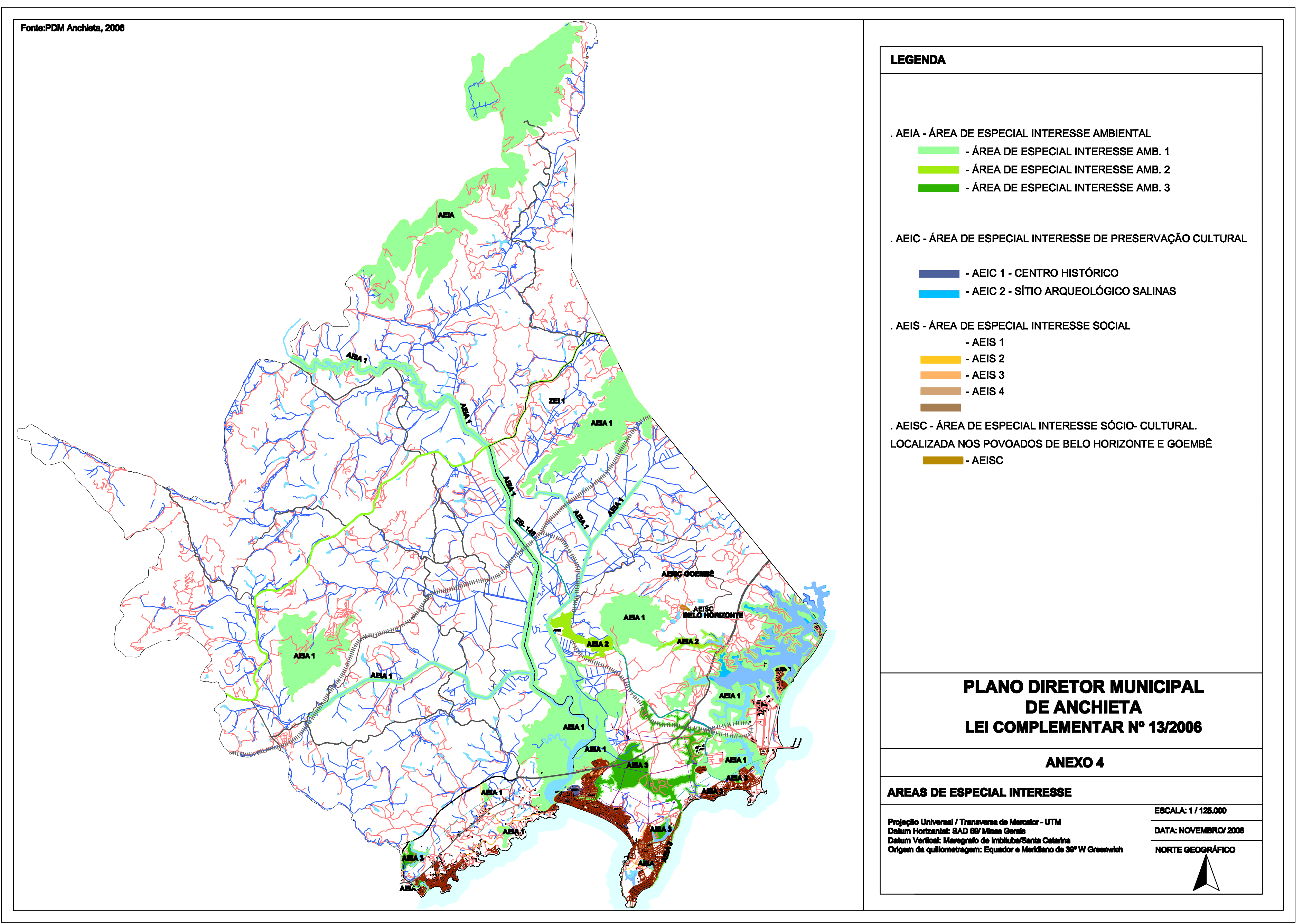


162| CAṔ́TLLO 4 
Integram ainda as Áreas de Conexão (AEIA 2), as seguintes unidades: Corredor Salinas e o Monte Urubu; Corredor Monte Urubu - Lagoa Mãe-Bá.(art.87). Quanto às áreas que integram as Áreas de Proteção (AEIA 3), foram elencadas as seguintes unidades: as faixas de praia, de uso dos banhistas, entre a linha de baixa mar e a linha de preamar; Parque Lagoa de Iriri; Parque Arerá; Parque Linear do Alvorada; Cinturão Verde de Anchieta; Parque Lagoa Icaraí; Parque Lagoa Thanharú; Parque Linear Guanabara-Parati; Parque Lagoa de Parati.

(PDM de Anchieta, 2006)

Pode-se constatar também que o Plano Diretor Municipal elenca um grande número de áreas de preservação e outras de fundamental importância para conexão dos ecossistemas, assim como as áreas de proteção. Considerando-se que o zoneamento proposto e aprovado pelo PDM de Anchieta dispõe de grandes áreas destinadas às zonas industriais contíguas a essas mesmas zonas de proteção ambiental ou de preservação permanente, as intenções preconizadas tornam-se incongruentes e obsoletas no âmbito da própria lei. Nesse sentido, o Plano Diretor de Anchieta pouco desenvolve e explicita os critérios para o atendimento à função social da cidade, mas, pelo contrário, gera impasses ao criar instrumentos de indução da expansão da atividade industrial em meio a áreas ambientalmente sensíveis. O município é rico em recursos hídricos, verificando-se a existência de rios navegáveis, numerosas lagoas e mangues. Portanto, é de extrema vulnerabilidade esta situação, se não houver um mecanismo eficiente de fiscalização e aplicação da lei para acompanhamento das atividades a serem implementadas, na medida em que equipamentos e tecnologias industriais estejam sendo gradativamente ampliados e instalados no território.

Para Souza (2006), pode-se assumir que o objetivo fundamental do planejamento e da gestão urbana é o tão desejado "desenvolvimento urbano", que, por sua vez, tem como características intrínsecas a melhoria da qualidade de vida e da justiça social. Esses podem ser compreendidos como objetivos relevantes, pois claramente dizem respeito aos fins e não somente aos meios. Ainda sob a análise do referido autor, metas como eficiência econômica e avanço técnico não devem ser vistos como fins em si mesmos, de um ponto de vista social abrangente e crítico; a rigor, em última 
instância, trata-se de meios a serviço de objetivos mais elevados. Estes objetivos merecem ser entendidos, portanto, como simples objetivos instrumentais. Nesse contexto, ao se trabalhar com questões relativas ao meio urbano e ambiental, a necessidade da abordagem interdisciplinar se coloca na medida em que se verifica que não somente as determinações legais são suficientes para assegurar a configuração do espaço de forma equilibrada. Assim, Souza é enfático na defesa de um planejamento autonomista:

\begin{abstract}
Devido ao seu cunho prático-político, as propostas de intervenção, mesmo tendo a sua formulação baseada em análises e diagnósticos, sobretudo condicionada por modelos normativos, sem contar, é evidente, as injunções políticas, necessitam de um ponto de vista autonomista ter a sua implementação submetida a escrutínio popular, ocasião em que poderão ser calibradas ou corrigidas [...] no caso de propostas de intervenção, quem deve deter a última palavra são, sob um ângulo autonomista, os envolvidos, cabendo ao pesquisador o papel de um interlocutor que propõe $\mathrm{e}$ alerta (para contradições, riscos, etc), mas jamais de um consultor que deseja impor ou sugere que se imponha.
\end{abstract}

(SOUZA, 2006, p.182-183)

Mesmo quando decisões externas - de ordem política ou econômica - tenham um papel decisivo na reestruturação socioeconômica do município ou localidade, o desenvolvimento local requer sempre alguma forma de mobilização e iniciativas dos atores locais em torno de um projeto coletivo. A autonomia será tanto maior quanto maiores as potencialidades locais e maior poder de organização da sociedade em torno de um projeto coletivo que articula o local com o global. Do contrário, o mais provável é que as mudanças geradas do exterior não se traduzam em efetivo desenvolvimento e não sejam internalizadas na estrutura social, econômica e cultural local, desencadeando a elevação das oportunidades, o dinamismo econômico e o aumento da qualidade de vida.

Nas experiências internacionais mais bem sucedidas, a política de desenvolvimento econômico local incorporou novos posicionamentos estratégicos. Está mudando das iniciativas anteriores, baseadas apenas no estabelecimento de incentivos aos investimentos externos e entrega de subvenções, para estratégias baseadas num melhor aproveitamento dos 
recursos endógenos dos diferentes territórios. Há que se ter como foco a estratégia de privilegiar não somente as macroestururas técnicas, não deixando de considerar as pequenas empresas como entidades viáveis e de relevância para o desenvolvimento local, desde que haja a efetiva contrapartida do poder público em apoiar essa estratégia.

Parece não haver, nos instrumentos de ordenamento do solo, uma compreensão mais nítida da realidade na qual o município está inserido, ou seja, a consideração de uma realidade mais ampla e complexa, com a qual o município interage e da qual recebe influências e pressões positivas e negativas. Se a falta de visão e o imediatismo são obstáculos para o planejamento em geral, a ausência de quadros técnicos suficientemente qualificados nos municípios, para aplicação e monitoramento dos planos diretores, é fator agravante. Resta a elaboração de planos terceirizados a escritórios privados, que os preparam dentro de um mesmo sistema, o que significa dizer, o mesmo receituário metodológico aplicado às mais diferentes realidades. Em consequência dos desajustes entre a concepção da lei e a interpretação da realidade cotidiana, o que se observa é que as cidades brasileiras continuam à mercê do imediatismo das soluções, do despreparo das municipalidades no enfrentamento de situações adversas originadas no próprio âmbito da administração pública.

Outro aspecto relevante a ser observado, é que, muitas vezes, não é realçada nos estudos e na formulação dos PDMs, a condição contemporânea da globalização. Para que o desenvolvimento local aconteça efetivamente, exige-se competitividade e especialização do município. Sob esta ótica, a globalização, além de representar alguma forma de integração econômica entre as diversas categorias do espaço, poderá também gerar e redefinir oportunidades e ameaças. Portanto, globalização e o desenvolvimento local são dois fenômenos que integram um mesmo processo complexo e contraditório exercendo forças de integração e desagregação. Ao mesmo tempo que a economia se globaliza, surgem novas formas de iniciativas no nível local, que podem ocorrer, com ou sem uma efetiva integração da dinâmica mundial. Tal situação produz processos diferenciados de desenvolvimento e, por vezes, conflitantes.

O Estado tem, contudo, grandes responsabilidades na construção e opera- 
ção de serviços básicos, na garantia de uma ordem jurídica. Portanto, o Estado tem a responsabilidade de monitorar e regular a formulação de planos diretores municipais e observar se a orientação das atividades econômicas não prejudica a estrutura física, social e ambiental do referido município. O Estado valida na lei a origem de tensões sociais que repercutem necessariamente no político. Nesse contexto, o Estado incapaz para modificar a referida orientação exaure-se na luta contra seus efeitos negativos. 


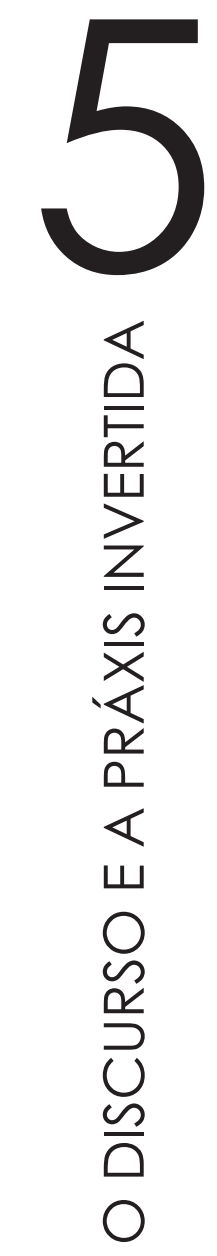

Objetos e ações contemporâneos são ambos, necessitados de discursos. Não há objeto que se use hoje sem discurso, da mesma maneira que as próprias ações tampouco se dão sem discurso. O discurso como base das coisas, nas suas propriedades escondidas, e o discurso como base da ação comandada de fora, impelem os homens a construir sua história através de práxis invertidas.

SANTOS (1994) 
168| CAPÍtULO 5 


\section{O DISCURSO E A PRÁXIS INVERTIDA |}

Uma breve análise do Plano 2025 do Governo do Estado do Espírito Santo e sobre a forma como ele viabiliza o discurso para que obtenha o respaldo necessário à sua implantação, é algo que impressiona pelo poder de inserção na sociedade capixaba. Na perspectiva do processo capitalista de produção, a informação é o vetor fundamental do processo social, e os territórios são equipados para facilitar a sua circulação - o território como instrumento. No âmbito da economia que caracteriza o capitalismo contemporâneo, as atividades econômicas e culturais permitem construir a imagem midiática dos espaços geográficos e podem ser consideradas como fazendo parte da esfera da circulação. A ênfase do Governo do Estado no quesito "Comunicação do Plano" é evidente. O discurso do Plano 2025 fundamenta-se na busca pela integração do território estadual e, consequentemente, do próprio mercado. O alcance desse objetivo se faz também por intermédio da ampla atividade publicitária. Nesse sentido, o Governo se alia às parcerias privadas, especialmente, os setores de telecomunicações, para efetivação de suas metas.

O marketing político tem por objetivo adaptar as políticas públicas aos costumes locais, porém obedecendo às necessidades de acumulação das empresas globais. Assim, as transformações no processo produtivo, engendradas na aceleração industrial e nas crescentes necessidades de expansão dos mercados, que caracterizam os projetos estratégicos formulados pelo Governo do Estado do Espírito Santo, fazem com que, ao processo produtivo sejam incorporadas novas atividades racionalizantes que envolvem a concepção, o controle e o marketing. É interessante mencionar a abordagem da jornalista Almeida Macedo ${ }^{1}$ em sua pesquisa de Mestrado intitulada: "A Emergência do Marketing na Política Capixaba: comunicação, imagem, símbolo e poder". A investigação relaciona o poder da comunicação na política e como este se manifesta por meio do marketing, especificamente no Espírito Santo, apresentando um novo método de produção de campanhas públicas.

1 MACEDO, Maria Helena de Almeida. A Emergência do Marketing na Política Capixaba: comunicação, imagem, símbolo e poder. Dissertação de Mestrado. Faculdade de História da Universidade Federal do Espírito Santo. 2007. 
Macedo (2007) argumenta que políticos experientes também contribuem de forma decisiva com o trabalho dos profissionais de comunicação, que, por sua vez, passam a assumir papel relevante em todas as campanhas eleitorais. A autora refere-se ao ano de 1990 como divisor de águas entre dois períodos diferenciados na história política capixaba recente: aquele que estabelece o fim da era da política tradicional, construída a partir da intuição, improvisação e por intermédio das relações interpessoais, e um novo período em que a prática política passa a sustentar-se na profissionalização do marketing. A hipótese analisada por Macedo refere-se à indagação sobre se o marketing político, pautado por instrumentos de comunicação de massa e acompanhamento permanente de tendências por meio de pesquisas de opinião, seria, por si só, capaz de alterar os rumos e modificar os resultados de campanhas eleitorais e, por conseguinte, a história política de indivíduos e grupos sociais.

\begin{abstract}
A política se dá pela conjugação de muitos fatores. Não há um isolado, ou que pese mais que o outro. Ela depende de articulações, do dinheiro que vai financiar as campanhas, pois o marketing custa caro. Política é uma coisa tediosa. É o marketing que vai afastar o tédio da política, transformála em espetáculo. O que conta é a cena. E, na chamada sociedade do espetáculo, muito mais importante que ser é parece.
\end{abstract}

(MACEDO, 2007, p.37)

A materialização da técnica na divulgação do Polo Anchieta provém de um discurso cuja estrutura revela sua funcionalidade. É o discurso do uso, mas, também, o da sedução. E há o discurso das ações, do qual depende sua legitimação. Essa legitimação prévia tornou-se necessária para que a ação proposta seja mais docilmente aceita e mais ativa se torne na vida social. Como o discurso invadiu o cotidiano, ele se torna presente em todos os lugares onde a modernidade se instala. Apenas para ilustrar a questão, no Brasil, indicadores mostram o aumento do número de pessoas alfabetizadas, mas, por outro lado, é reduzido o número de pessoas com capacidade de julgamento e compreensão da informação gerada pela ação. Nessa perspectiva, Milton Santos afirma que "o discurso das ações e o discurso dos objetos às vezes se completam como base da desinformação e da contra-informação" (SANTOS, 2008, p.227). 
Para Foucault (1999), o objeto só ganha significação no discurso. A cada discurso, temporalmente, têm-se os objetos, ou seja, o discurso é a condição da possibilidade do aparecimento, da diferenciação ou do desaparecimento dos objetos. Outra consideração importante é a de que não existe unidade do discurso, mesmo com base na ideia de um objeto, seguindo, uma constante ou um "estilo"; o fato de o discurso ser uma prática, ou seja, uma "prática discursiva" é, pois, conjuntural, estabelecido no tempo e no espaço. Segundo o autor, o relevante é compreender, a partir da heterogeneidade dos discursos, a condição de existência, a regra de formação das ditas práticas discursivas. Agindo assim, há possibilidade de um saber, uma verdade localizada num determinado contexto.

A história não é uma construção contínua e unitária, mas um descontínuo passar de períodos, emergindo, a cada vez, uma verdade regional e limitada ao seu tempo (epistémé), que representa uma homogeneidade primeira que ordena toda a heterogeneidade. A ideia de verdade se apresenta como critério de verificação do "enunciado" perspectiva analítica de Foucault (1998), a descontinuidade permite a visão histórica de novos regimes, novas instâncias - que não guardam nenhum contato hierárquico com antecessores e sucessores: é apenas mudança das condições de existência dos saberes. As mudanças não decorrem de um desenvolvimento ou retrocesso, mas, na verdade, de uma realocação, rearranjo, reestruturação das relações entre os saberes (FOUCAULT apud LIMA, 2009,p.218).

\footnotetext{
O dispositivo estratégico que permite escolher, entre todos os enunciados possíveis, aqueles que poderão ser aceitáveis no interior, não digo de uma teoria científica, mas de um campo de cientificidade, e a respeito do que se poderá dizer: é falso, é verdadeiro. É o dispositivo que permite separar não o verdadeiro do falso, mas o inqualificável do qualificável.
}

(FOUCAULT,1998,p.247)

No entender de Foucault, fazer história, portanto, é observar a política das

2 A palavra "enunciado" aqui não remete a uma idéia gramatical de frase. No entender de Deleuze, o eneunciado se instalará numa espécie de diagonal, que tornara legível o que não poderia ser apreendido de lugar nenhum. O enunciado é uma função de existência dos mais variados signos. A arqueologia, observando um conjunto de enunciados visa compreender uma condição de existência dos discursos. 
verdades desde as estruturas íntimas de força, a partir da capilaridade de poder. Não há um sujeito ou um objeto a priori, mas apenas construções e definições de acordo com as relações de força. A descontinuidade não representa um ceticismo, mas o reconhecimento da possibilidade apenas localizada. Com isso, na genealogia do poder, há um deslocamento da importância do sujeito do conhecimento e do objeto cognoscível para as relações de poder historicamente definidas. Para Foucault, a produção de discursos "verdadeiros" ( que, além disso, mudam incessantemente) é um dos problemas fundamentais ${ }^{3}$. Desse modo, a historia da "verdade" - do poder próprio aos discursos aceitos como verdadeiros - está totalmente por ser feita (FOUCAULT, apud VEYNE,1998, p.268).

Retornando à questão da forma discursiva, em meio à dispersão de discursos, o objetivo é encontrar dobras, isto é, regras que conduzem e formam os discursos. Significa que, em que pese a heterogeneidade dos discursos, admitem-se "esquemas" de entrecruzamentos que formam regularidades. Portanto, poderíamos admitir que há um método no discurso, um meio eficaz para atingir o objetivo, um instrumento seguro para a prática racional e científica.

Hoje, o discurso preponderante é o da globalização e respectivos processos a ela vinculados. Nos discursos dos políticos, em artigos nos jornais, na televisão, na literatura, "globalização" é uma dessas palavras/conceitos que parecem estar em toda parte ao nosso redor, sendo ela essencial para compreensão da sociedade contemporânea. Parece haver uma rachadura, um corte na história que inaugura uma nova temporalidade. Um dos maiores impactos da globalização vem se dando na hierarquia das cidades, que passam a ter um novo papel estratégico: as cidades ditas mundiais visam atender à flexibilização da produção e aos novos fluxos tecnológicos, funcionando como pontos direcionais da organização da economia mundial. Para os teóricos da globalização, apesar da desintegração social, da violência e do despreparo das cidades para receberem os objetos técnicos, o futuro da humanidade estaria condicionado inexoravelmente a esse novo

3 Fazendo uma analogia sobre a afirmação da descontinuidade dos discursos no âmbito da história, Foucault, referencia-se à loucura, religião, medicina, dentre outros exemplos, que numa busca de pontos em comum, ao longo do tempo, verificar-se-á apenas identidade no nome, mas concepções e práticas heterogêneas, de acordo com cada relação política: essas práticas em cada estrato temporal são inventadas e reinventadas pela história. 
modelo.

O discurso tem por base a ideia motriz de que as cidades são concebidas para atrair investimentos, gerar empregos e renovar a base produtiva a partir da ação conjunta de vários atores. Em geral, as experiências mostram que o protagonismo dos atores está bem mais situado na estratégia da globalização por meio dos Planos Estratégicos, do que na busca de alternativas para atendimento das necessidades dos excluídos do processo de articulação e instalação das redes técnicas.

Santos (2008) argumenta que, ao mesmo tempo em que se instala uma tecnosfera dependente da ciência e da tecnologia, cria-se, paralelamente, e com mesmas bases, uma psicosfera. A tecnosfera se adapta aos mandamentos da produção e do intercâmbio e, frequentemente, traduz interesses distantes; a psicosfera, reino das ideias, crenças, paixões, também faz parte desse ambiente, fornecendo regras à racionalidade ou estimulando o imaginário. Ambas - tecnosfera e psicosfera - são locais, mas constituem o produto de uma sociedade bem mais ampla que o lugar (SANTOS, 2008, p.256).

Segundo A.C. Ribeiro (1991), a relação entre "a organização da estrutura produtiva do país, e a criação de uma base técnica e econômica dos processos modernos de comunicação é identificada como elo agilizador e articulador dos mercados [...] essa psicosfera consolida a base social da técnica e a adequação comportamental à interação moderna entre tecnologia e valores sociais". ${ }^{4}$

Os espaços da globalização apresentam cargas diferentes de conteúdo técnico e de conteúdo informacional. O meio geográfico é hoje, tendencialmente um "meio técnico-científico" e, graças ao seu conteúdo, condiciona os novos comportamentos humanos, que por sua vez, aceleram a utilização de recursos técnicos. Se "tecnosfera e psicosfera são os dois pilares com os quais o meio-científico introduz a racionalidade e a contra-racionalidade, no próprio conteúdo do território" (SANTOS, 1996, p.204), é possível supor que ambos os conceitos formulados por Santos

4 RIBEIRO apud SANTOS, 2008, p. 256. POR TRÁS dos investimentos, riqueza já está no ar no Estado. 
- psicosfera e tecnosfera - têm profundas repercussões na prática econômica, e nos comportamentos sociais e políticos, constituindo uma base nova para o entendimento do processo que se instaura no Espírito Santo a partir da concepção do Plano 2025. Para o autor, espaços da globalização se definem pela presença conjunta, indissociável, de uma tecnosfera e de uma psicosfera que, juntas, funcionam de modo unitário e formam o meio técnico-científico. A tecnosfera é o mundo dos objetos, a psicosfera é a esfera da ação (SANTOS, 2008, p.257).

\footnotetext{
Os objetos têm um discurso que vem de sua estrutura e revela sua funcionalidade. É o discurso do uso, mas, também, o da sedução. E há o discurso das ações, do qual depende sua legitimação. Essa legitimação prévia tornou-se necessária para que a ação proposta seja mais docilmente aceita, e mais ativa se torne na vida social.
}

(SANTOS, 2008, p.227)

As intervenções humanas que possam produzir impactos de qualquer ordem alteram significados sociais. Nesse contexto, todo elemento espacial é representação e informação, com capacidade "incessante de gerar social, histórica e psiquicamente um imaginário da cidade. O imaginário se manifesta no fazer histórico e na constituição de um universo de significações". (CASTORIADIS, 1982, p.12). A imagem de um território, especificamente tratando-se do Polo Anchieta, corresponde à assinatura dos poderes públicos e técnicos sobre essa imagem. Institucionalizada a imagem, esta garante a estabilidade desse poder à medida que é apreendida, que circunscreve seus limites e justificativas e que se acredita eficiente porque permanece no imaginário coletivo. Na interpretação de Ferrara (2000, p.120), "a iconicidade da imagem é o recurso utilizado para resgatar a aparência global e é responsável pela tentativa de fazer o território, sobretudo a cidade moderna, apresentar uma perspectiva sempre renovada, saneada e adequada aos novos contextos técnicos e informacionais".

O descompasso e as contradições entre a divulgação massiva dos projetos contemplados no Plano 2025, e em especial no Polo Industrial de Anchieta, impressionam pela intenção de persuadir a população da possibilidade de ascensão econômica do estado do Espírito Santo, mas, por outro lado, escamoteiam símbolos e identidades que impedem o reconhecimento das 
suas múltiplas e díspares imagens, que, por sua vez, envolvem também e de forma simultânea, tradições histórico-culturais e riquezas ecológicas. Essa dicotomia faz com que a visibilidade do território seja simultaneamente reduzida e ampliada. Digo reduzida, quando se considera que a imagem do Polo Industrial de Anchieta está diretamente vinculada a uma imagem soberana e importada do processo de globalização, a qual cria uma formação de opinião relacionada apenas às perspectivas de geração de riquezas; e ampliada, porque somente por meio de outros "olhares" é possível perceber a problemática da dimensão local. Enfim, uma duplicidade que impõe encontrar, no território de Anchieta e em seu entorno, a dinâmica de uma alteridade global que entra em conflito com a imagem que lhe permitiria identificar-se como diversidade.

Em Anchieta, medo e esperança se misturam. Seus 20 mil habitantes vivem na expectativa da chegada de um verdadeiro "milagre econômico". A população da cidade, que sempre viveu essencialmente da pesca, do turismo e do comércio local, assiste à chegada, de uma só vez, de vários empreendimentos econômicos de grande porte. Considerando o ano de 2007 até agora, a cidade de Anchieta e a região na qual ela se insere, registraram um aumento de população estimado em torno de 4 mil pessoas, muitas delas trabalhadoras de empresas instaladas na região, onde já acontecem as obras de expansão da SAMARCO, as implantações do gasoduto e da UTG Sul da Petrobras.

A chamada para a manchete do jornal A Gazeta "Por trás dos investimentos, riqueza já está no ar no Estado" nos leva a crer que a atividade informacional desperta para um imaginário coletivo a possibilidade de uma vida rica, permeada pelo espetáculo de mercadorias e serviços:

"Pare e responda: há cinco anos existiam no Estado - em especial na Grande Vitória - tantos restaurantes e prédios modernos como hoje? E serviço de "personal coach", você conhecia algum ou sabe do que se trata? A maioria dos leitores deve ter respondido não às três perguntas. [...] Nesse setor, o destaque são as lojas e padarias "chiques". Vide o exemplo da La Bassetti e Marca Registrada , que vendem jeans Premium. Mas são os mesmos que já estão usufruindo de serviços inexistentes antes, do dobro da oferta de imóveis - para todos os bolsos e gostos - e de restaurantes 
com padrão de exigência internacional. O segmento imobiliário registrou um aumento de $116 \%$ na quantidade de imóveis em construção, nos últimos cinco anos. Enfim, uma série de facilidades existentes em cidades como Rio de Janeiro, São Paulo e Brasília, que antes não se via aqui. Essas mudanças são sinais de que o Espírito Santo está, de fato, crescendo." 5

Com base na argumentação de Santos (1996, apud FERRARA) em que a "tecnosfera e psicosfera são redutíveis uma a outra", Ferrara afirma ser possível supor que a imagem virtual da cidade não facilita a apropriação do espaço urbano, ao contrário, aliena as consciências podendo transformar o exercício da cidadania em uma asserção ultrapassada e sem sentido. Entretanto, o meio técnico-científico tem seu diferencial provido pela dimensão informacional, ou seja, é próprio do meio técnico divulgar informações que se organizam em cadeias, de sorte que toda informação produz informação que, em conseqüência produz aprendizagem e mudanças de comportamento. A informação não é um dado, mas um processo relacional que se estabelece entre o repertório de experiências pregressas do indivíduo e a nova informação ou o desafio do conhecimento que se impõe. Portanto, para Ferrara, não é possível pensar na redutibilidade inexorável entre tecnosfera e psicosfera. Na interpretação da autora, "sob o impacto da globalização tecnológica da informação, tecnosfera e psicosfera não se superpõem, mas, ao contrário, flexibilizam-se de modo que a tecnosfera propõe para a psicosfera desafios informacionais que poderão levar, sem determinismos, a alterações de escalas de valores, crenças e comportamentos" (FERRARA, 2000,p.95).

$\mathrm{Na}$ realidade, qualquer grande empreendimento traz consigo transformações nem sempre positivas para o lugar onde se instala. Entretanto, quando os lugares já abrigam de antemão, os problemas inerentes à desigualdade socioespacial (pobreza, desemprego, concentração fundiária), a desestruturação é muito mais profunda, deixando mais latentes as contradições impostas pela maneira como a sociedade atual se organiza e distribui poderes e riquezas. O Estado perde o controle das informações e respectivos impactos que possam ser gerados no território. Nessa perspectiva, o estabelecimento de parcerias privadas parece desobrigar o poder público do 


\section{Construção é barata no Estado, e valor de imóvel pronto é $30 \%$ maior}

\section{Moradores vencem luta, e Val- terá que controlay -ó 3 billhões Aracruz vai investir Rrica no Estado em sua quar}

Calçadão no final de Camburi não
vai ganhar nem iluminação nova

Mercado aquecido: valor 40\% no ano imóveis Para $61,7 \%$ dos capixabas, imóveis País descobre mar de petróleo. E a exploração começa por aqui

Cidades se transformaram nuin grande canteiro de obras

ANP vende 18 blocos
de petróleo no Estado

FIG. 31

As manchetes freqüentemente veiculadas nos jornais capixabas e que fazem alusão ao crescimento econômico e geração de riqueza. Fonte: Acervo pessoal.
Os "jogos de linguagem", o "significante", o "texto", as "narrativas", o "discurso" que designam o universo dos signos. $\mathrm{O}$ texto e a linguagem criam o sentido, chegam mesmo a produzir referências internas aos discursos e locutores instalados nos discursos (GREIMAS e CORTĖS,1979). O texto torna-se original, aquilo que ele exprime, ou veicula, torna-se secundário. Os sujeitos falantes transformam-se, cada um deles, em ficções geradas pelos efeitos de sentido (ECO,1985). Os objetos de que falamos se tornam efei- 
tos de realidade deslizando na superfície da escritura. Tudo torna-se signo e sistema de signos (BARTHES,1985).

(LATOUR, 2000, p.63)

Toda essa divulgação dos projetos no litoral sul - polarizado por Anchieta - acaba por influenciar outras esferas de poder econômico que engendram novas formas de organização do espaço e acirram as desigualdades regionais. Em termos físico-territoriais, as ações da mídia desencadeiam importantes vetores de expansão da malha urbana, determinando a ordem de sua ocupação e reestruturando-a em função da ampliação ou da implantação de infraestrutura de transporte e da ocupação de extensas áreas destinadas à instalação de grandes plantas industriais e criação de novos bairros residenciais.

Logicamente, o impacto de tanto investimento será sentido também pelas cidades vizinhas. Os municípios de Piúma, Guarapari e Iconha e até mesmo aqueles que integram a RMGV, tais como Vila Velha e Vitória, receberão os reflexos do Polo Anchieta ${ }^{6}$. A perspectiva de crescimento urbano já é previsível, assim como a valorização do mercado imobiliário sugerindo novos negócios e ampliando margem de lucros pela especulação imobiliária respaldada pela ação da mídia. Portanto, estas interferências de ordem global repercutem nas várias escalas do espaço: desde a escala local, através da subordinação e do uso dos lugares para tornar o capital mais fluido, passando pela escala regional, que materializa manifestações específicas ou dirigidas do capital, incidindo na escala urbana local.

A privatização do sistema corresponde a uma modificação das modalidades de distribuição dos produtos e dos serviços técnico-informacionais. No âmbito da lógica de globalização, a implantação dessas redes gera novas modalidades de exclusão social. Mediante discursos exaustivos para aceitação e posterior implantação dos projetos se criam imaginários espetaculares que conformam o pensamento e, de certa forma, anestesiam a capacidade da população em decifrar os processos das tecnologias de rede. E o que é pior, ênfase midiática tende a atrofiar a competência de atuar de modo transformador e reflexivo criticamente a respeito da condução política e econômica do território em que habitam. Marcuse (1964,apud

6 Os municípios de Guarapari e Vila Velha integram a Região Metropolitana de Vitória, porém o s reflexos da criação desse novo pólo econômico regional serão replicados por toda R.MGV, especialmente no que se refere ao mercado imobiliário e demanda por serviços e comércio. 
SANTOS, 1994, p.21) afirma:

Essa linguagem constantemente impõe imagens e contribui, de forma militante, contra o desenvolvimento e a expressão de conceitos. A palavra torna-se um clichê, e como clichê, governa o discurso ou o texto; a comunicação, desse modo, afasta do desenvolvimento genuíno da significação.

O discurso que ouvimos todos os dias pela mídia nos faz crer que a globalização necessita de um Estado flexível a seus interesses. Em tal contexto, as fronteiras deixam de ser rígidas, o que leva ao enfraquecimento e à mudança de natureza dos Estados nacionais. Além disso, a instalação desses capitais globalizados supõe que o território se adapte às suas necessidades de fluidez, investindo pesadamente para alterar a geografia das regiões escolhidas. O Estado também se preocupa em oferecer condições competitivas de infraestrutura de circulação do território para esses grandes projetos do circuito espacial produtivo.

Os processos acima mencionados estão estreitamente relacionados com o afastamento do Estado da regulação do território em todos os seus aspectos, assim como políticas de interesse social. Este comportamento generalizado dos Estados, também se aplica diretamente no Espírito Santo, o que leva a uma supressão do discurso territorial adotado na retórica do Estado e à desconsideração dos processos espaciais resultantes da dinâmica da sociedade e da economia.

A dimensão do controle social constitui-se em importante elemento na ação de organizações locais sobre grandes projetos de multinacionais, instituições multilaterais e governos, com a exigência de transparência dos recursos de origem pública investidos. As populações atingidas, sobretudo os grupos sociais de menor força, começam a resistir e buscar alternativas. Entretanto, tais iniciativas são ainda de reduzido impacto na opinião pública e de pouca influência nas instituições governamentais que coordenam o estabelecimento dos fluxos globais.

\subsection{A retórica e o mito da "sustentabilidade"}

A retórica do mercado tem sido o componente central 
nesta luta ideológica pela legitimação ou deslegitimação do discurso. Os conteúdos da própria mídia são então lançados em uma versão mais ampliada do mercado a que se incorporam de tal forma que as duas coisas se tornam impossíveis de distinguir.

(JAMESON, 2006, p. 284)

É importante salientar as diversas interfaces do discurso utilizado pelo poder público em parceria com o privado para viabilizar a implantação dos projetos vinculados ao Plano 2025. Estratégias de marketing, especialmente aquelas veiculadas pelo setor de telecomunicações de maior penetração na sociedade capixaba, vêm sendo realizadas enfaticamente, subordinando o planejamento das ações a uma justificativa de "desenvolvimento sustentável". Poucos conceitos têm sido tão amplamente utilizados nas políticas públicas como esse; e no entanto, seu aparente consenso revela mais imprecisão do que clareza em torno do seu significado. À primeira vista, trata-se de um desgaste típico do jargão que, repetido à exaustão, acaba por esvaziá-lo de significado. Algumas das indagações do próprio Plano 2025 nos leva a uma reflexão sobre o seu discurso: Como estará o Espírito Santo em 2025? Como evoluirão os níveis de pobreza e de desigualdade social? (Plano 2025, 2006, p.16 e 37). Apesar das preocupações pertinentes, quando o Plano 2025 se refere ao termo "sustentabilidade", de que se trata, para quem se viabiliza e de que maneira?

A adoção do conceito de desenvolvimento urbano sustentável faz-se muitas vezes com base nas práticas do planejamento e respectivas propostas de intervenção, sem grandes questionamentos acerca das formulações teóricas que lhe servem de suporte, o que se traduz no distanciamento entre a análise social/urbana crítica e a do planejamento urbano. O discurso ambiental se mistura com o do planejamento e da intervenção sobre o ambiente construído. Diversas matrizes discursivas têm sido associadas à noção de sustentabilidade, desde que o documento "Nosso Futuro Comum", também conhecido como "Relatório Brundtland"”, a lançou no debate internacional e popularizou a expressão. É importante considerar que a discussão leva necessariamente à noção de que há sempre um conflito inerente ao termo, uma contradição entre a vertente ambiental e a 
urbana.

A suposta imprecisão do conceito de sustentabilidade sugere que não há mais hegemonia estabelecida entre os diferentes discursos. A visão sociopolítica tem se restringido ao esforço das ONGs, mas precisamente na atribuição de precedência ao discurso da equidade com ênfase no âmbito das relações internacionais. Para Ascerald (1999, p.82-83), o discurso econômico foi o que, sem dúvida, melhor se apropriou da noção até aqui. A recusa do antagonismo entre o meio ambiente e a economia fará também da busca da sustentabilidade urbana a ocasião de fazer valer a potência simbólica do mercado como instância de regulação das cidades. Ascerald conduz sua reflexão sobre o debate da sustentabilidade, considerando três representações distintas, com base na articulação entre a reprodução das estruturas urbanas e sua base especificamente material:

- Cidade sustentável: será aquela que, para uma mesma oferta de serviços, minimizará o consumo de energia fóssil e de outros recursos materiais, explorando ao máximo os fluxos locais e satisfazendo o critério de conservação de estoques e redução de volumes de rejeitos; a concepção da sustentabilidade como trajetória progressiva é normalmente acompanhada de uma base social de apoio a projetos de mudança técnica, pela via da educação ambiental, de projetos comunitários.

- Insustentabilidade: é a incapacidade adaptativa de reprodução das estruturas urbanas diante da ruptura das condições materiais e de grandes assimetrias entre a localização espacial dos recursos e a da população.

- Metabolismo urbano: refere-se à resiliência das estruturas urbanas, ou seja, à capacidade adaptativa dos ecossistemas urbanos de superarem a sua condição de vulnerabilidade ante os choques externos.

Muitos teóricos que estudam a questão optam por trabalhar com o argumento da "insustentabilidade" do conceito, especialmente se inserido no contexto dos países em desenvolvimento. A noção de sustentabilidade seria incongruente com o desenvolvimento, pois o capitalismo gera desigualdades. A insustentabilidade exprime, assim, a incapacidade das políticas urbanas de adaptar a oferta de serviços urbanos à quantidade e 
à qualidade das demandas sociais, provocando um desequilíbrio entre necessidades cotidianas da população e os meios de satisfazê-las com investimentos em redes e infra-estrutura. Prevalece a ideia da impossibilidade de uma solidariedade capitalista. Por outro lado, se a expressão é vista como algo desejável, abre-se, portanto, uma luta simbólica pelo reconhecimento da autoridade para falar em sustentabilidade. Poderíamos dizer, então, sustentáveis as práticas que se pretendam compatíveis com a qualidade futura postulada como desejável. Tal consideração nos remete a processos de legitimação/deslegitimação de práticas e atores sociais.

Hoje, a vanguarda da análise social crítica pertence aos estudos culturais, especialmente na literatura americana, onde as análises enfatizam as contradições da sociedade expressas nas diferenças de raça, étnico-cultural, entre outras. Tal abertura trouxe um novo significado para a orientação da ação política. Os estudos urbanos contemporâneos fazem uma distinção entre a área do planejamento e a da análise social crítica. Tal distinção está associada aos caminhos percorridos pelo planejamento urbano, que, ao institucionalizar-se, se tornou excessivamente burocratizado e pouco permeável às diferenças cada vez mais acentuadas. Paradoxalmente, esse mesmo planejamento vem, progressivamente incorporando o discurso da sustentabilidade urbana, o que torna imprescindível uma clara explicitação do conceito de sustentabilidade quando associado a algum plano estratégico do poder público.

Um divisor de águas importante nessa discussão entre a análise ambiental e as ciências sociais diz respeito à aceitação ou não do atual projeto de modernidade (capitalista ocidental), que tem no discurso sobre desenvolvimento (sustentável) a sua mais abrangente tradução. De um lado, vários autores, ainda que de forma crítica, desenvolvem mecanismos de articulação entre os diversos agentes em conflito (COLBY,1990;BARBIER,1987), tendo como ponto de partida a "versão oficial" de que há uma preocupação com a redistribuição, com as desigualdades e com a identificação de novos caminhos. Por outro lado, situam-se abordagens que rejeitam a modernidade em sua versão hegemônica, como por exemplo, a de Escobar (1995, apud COSTA) que, além de desconstruir o desenvolvimento sustentável como discurso, busca compreender as novas formas de internalização da natureza pelo capital na atualidade. Escobar desenvolve 
a idéia de um capitalismo pós-moderno em que a natureza é reinventada, por meio de linguagens, como a dos sistemas e da biotecnologia. Além da conquista simbólica da natureza e das comunidades, há a conquista dos saberes e dos conhecimentos locais (COSTA, 2000, p.62-63).

Feitas essas análises comparativas das abordagens teóricas, tem sentido reforçar uma das hipóteses iniciais da tese, segundo a qual o discurso do desenvolvimento sustentável foi facilmente assimilado pelo planejamento urbano, mas não pela análise espacial crítica. Parece haver consenso, pelo menos entre os autores mais críticos, a idéia de que a prática do planejamento urbano só tende a manter o status quo e a reforçar um projeto de modernidade/ globalidade. Em síntese, pode-se dizer que o campo dos estudos ambientais vem experimentando o alargamento de suas bases conceituais e a multiplicação da quantidade de estudos e áreas do conhecimento envolvidas. Entretanto, os estudos mostram que, em grande parte das experiências locais e regionais do planejamento, a dimensão espacial / urbana permanece subestimada, sendo, às vezes, inexistente, ou até mesmo negada em sua interface ambiental. Vários outros aspectos de maior relevância giram em torno do conceito de sustentabilidade, como a ideia de autonomia da comunidade no processo de planejar; porém o conceito por ser abrangente, capaz de alinhavar iniciativas e propostas de diversas origens, tende a ser banalizado e transformado em peça de retórica. 


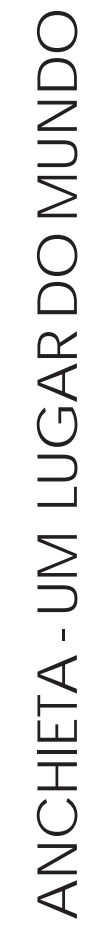

É pelo lugar que vemos o mundo e ajustamos nossa interpretação, pois nele o recôndito, o permanente, o real triunfam, afinal, sobre o movimento, o passageiro, o imposto de fora......

Mas, se o lugar nos engana, é por conta do mundo.

Santos apud Leite (2004b, p.51) 
Ao se pensar o Polo Industrial de Anchieta como um objeto técnico, não há como deixar de associá-lo ao lugar Anchieta ${ }^{79}$ - uma pequena cidade litorânea com signos representativos da história jesuítica - e também ao mundo. Os objetos têm um papel importante na produção das ações, e a maneira pela qual dispomos os objetos técnicos, altamente carregados de ideologia, não nos permite pensar o lugar sem olhar para o mundo. Essa condição faz com que a história do lugar passe, cada vez mais, para além de seus limites físicos. Isso significa dizer que a simultaneidade entre ações locais/globais, mais do que determinar a natureza do lugar, hoje, esclarece a articulação entre as diversas escalas territoriais.

O lugar representa e fixa relações e práticas, produzindo uma identidade complexa que diz respeito ao mesmo tempo ao local e ao global. Para Augé (2004) o lugar, antes de tudo, é necessariamente histórico a partir do momento em que, conjugando identidade e relação, ele se define por uma estabilidade mínima. Por isso é que aqueles nele vivem podem aí se reconhecerem.

\footnotetext{
O lugar antropológico é ambíguo. Ele é apenas a idéia, parcialmente materializada, que têm aqueles que o habitam de sua relação com o território, com seus próximos e com os outros. Essa idéia pode ser parcial ou mitificada. Ela varia com o lugar e o ponto de vista que cada um ocupa. Não importa: ele propõe e impõe uma série de marcas que, sem dúvida, não são aquelas da harmonia selvagem ou do paraíso perdido, mas cuja ausência, quando desaparecem, não se preenche com facilidade.
}

(AUGÉ, 2004, p.54)

Podemos dizer que o lugar envolve a idéia de uma construção, tecida pro relações sociais que se realizam no plano do vivido, o que garante uma

79 A cidade de Anchieta, antiga aldeia indígena de Riritiba, é uma ocupação das mais antigas do Espírito Santo. Embora sua história contemple toda a época colonial, foi o período de permanência dos jesuítas na colônia - entre o século XVI e o ano de 1759 - que teve maior significado para seu desenvolvimento. Com uma área territorial de aproximadamente $420 \mathrm{~km}^{2} \mathrm{o}$ município faz divisa com Guarapri e com Alfredo Chaves ao norte, Piúma e Oceano Atlântico ao sul, Oceano Atlântico a leste, Iconha e Alfredo Chaves a oeste. A cidade de Anchieta está localizada no sul do Espírito Santo a 71 quilômetros da capital de Vitória. 
rede de significados e sentidos que são tecidos pela história, O lugar é relacional e identitário, entretanto, Augé reconhece que as interdependências inéditas do que alguns chamam de "sistema-mundo", traz incontestavelmente um problema para os historiadores contemporâneos: a ameaça de supressão de todo e qualquer significado (AUGÉ, 2004, p.31). Os constantes deslocamentos do olhar para o mundo e respectivas imagens desiderativas podem conduzir, no entender de Augé a novíssimas vivências de solidão ou de tensão solitária, a que o autor propõe chamar da experiência da supermodernidade. Este sentimento conflituoso é reflexo da coexistência de mundos e à experiência combinada do lugar e daquele que não o é mais - o "não-lugar".

$\mathrm{Na}$ atualidade, essa situação cambiante em que o indivíduo está sempre se interpondo entre o lugar de vida e o mundo, se torna cada vez mais freqüente. Há que se ressaltar a dimensão do tempo em cada lugar onde o objeto ou evento é ponto de interlocução no presente e no passado. A globalização que atinge os lugares produz novos conflitos que se inscrevem no espaço e no cotidiano, alterando se com isso, os traços, as realizações e as relações dos sujeitos da história. A perspectiva de inserção das cidades do litoral sul do Espírito Santo no contexto das redes globais faz com que se acelere o fluxo do movimento em direção a novo ciclo de modernização, de modo que as cidades locais estejam aptas a ganhar mercados e novos investimentos financeiros.

Ante a globalização, muitas variáveis externas se apresentam, e as cidades podem se beneficiar ou não das circunstâncias geradas pela especialização produtiva, conforme enfatiza Santos: "o lugar é o encontro entre possibilidades latentes e oportunidades preexistentes ou criadas. Estas limitam a concretização das ocasiões" (SANTOS,1994, p.44). A rede de cidades locais consiste, de modo geral, em uma estrutura mais complexa, indiscutivelmente ligada às transformações do modelo de consumo no mundo, sob o impacto da modernização tecnológica. Nessa perspectiva, a diferença maior entre as cidades encontra-se nas relações históricas que elas estabelecem com o espaço regional no qual se encontram inseridas. Como cidades periféricas, a serviço de um modelo de desenvolvimento concentrador e gerador de acumulação de capital, passam a atender a interesses distantes, além de possuírem zonas de influência e espaços derivados ex- 
tremamente dependentes de fatores externos.

Na contextualização de um fato novo, extremamente impactante, há de se considerar a interdependência entre o fenômeno, o lugar e mundo, condição esta inerente ao movimento do espaço. Portanto, analisar a implantação de um polo industrial supõe enfrentar o desafio de compreendê-lo como elemento de ressignificação da cidade por meio dos valores culturais de seus cidadãos, de uma coletividade. A probabilidade de erosão dos valores tradicionais se soma à mobilidade mais intensa e à facilidade das comunicações para criar situações profundamente novas para a maioria da população de Anchieta. Novas oportunidades se abrem, e, com elas, novos valores. Para entendermos como um determinado objeto técnico ou o conjunto deles atinge e transforma o lugar, Santos usa o argumento de que o espaço geográfico agrupa horizontalidades e verticalidades, a saber:

\begin{abstract}
O espaço geográfico, banal em qualquer escala, agrupa horizontalidades e verticalidades. As horizontalidades expressam o domínio de um cotidiano territorialmente partilhado com tendência a criar suas próprias normas, fundadas na similitude ou na complementaridade das produções e no exercício de uma existência solidária. A horizontalidade, enquanto conjunto de lugares contíguos, é o substrato dos processos da produção propriamente dita, da divisão territorial do trabalho, ao passo que a verticalidade se associa aos processos da cooperação, cuja escala geográfica não raro ultrapassa a do processo direto da produção.[...]. Em relação às horizontalidades, o vetor da verticalização é um elemento perturbador, já que implica uma necessidade de mudança. Assim, regulação e tensão se tornam indissociáveis em cada lugar. As horizontalidades são os alicerces de todos os cotidianos, isto é, do cotidiano de todos. As verticalidades agrupam áreas ou pontos, ao serviço de atores hegemônicos não raro distantes. São os vetores da integração hierárquica regulada, doravante necessária em todos os lugares da produção globalizada e controlada a distância.
\end{abstract}

(SANTOS, 1997, p.44 e 45)

Com base na argumentação de Santos, as cidades são entendidas como pontos de interseção e superposição entre horizontalidades e verticalidades, constituindo uma espécie de geometria variável, levando em conta a maneira como as diferentes aglomerações participam do jogo entre o local 
e o global. O esforço para a compreensão das possibilidades de reorganização espacial dos lugares atingidos pela implantação do Polo Anchieta, com base nos mecanismos de articulação do espaço global, deverá revelar contradições inerentes ao processo de construção da paisagem, sempre refeita em conformidade com as relações produtivas. Santos afirma que a “internalização" do externo não se dá de forma arbitrária, mas em lugares específicos, e que nenhuma variável externa se integra numa situação se esta não tem as condições para poder aceitá-la. Portanto, o que define um lugar "é todo um contexto formado por uma teia de objetos e ações com causa e efeito, que atinge todas as variáveis já existentes; e as novas, que se vão internalizar" (SANTOS, 1998 ,p.97).

A partir do momento em que já não é mais possível entender a paisagem urbana de um determinado lugar sem recorrer ao conhecimento das redes globais que a ultrapassam, torna-se necessário o entendimento dos fatores que incidem em lugares específicos. Considerando o processo de transformação ao qual está submetida a paisagem do litoral sul, o argumento de Santos para a eficácia do fator externo é a forma de acomodação, ou seja, varia conforme sejam os lugares e os valores internos a eles.

Os lugares e respectivamente as paisagens se diferenciam pela maneira pelo qual os fatores internos resistem aos externos, determinando as modalidades do impacto sobre a organização preexistente. A partir desse choque impõe-se uma nova combinação de variáveis, outro arranjo, destinado a se manter em constante movimento.

(SANTOS, 1998,p.97)

As variáveis externas se internalizam, incorporando-se à escala local. Esse processo, se, de um lado, aprofunda a relação entre os lugares, de outro muda os requisitos e atributos do lugar, aprofundando as contradições entre o local e o mundial.

A questão do lugar é indissociável do movimento global. Embora se possam questionar os diferentes graus de transformação que atingem uma região, é quase unânime que mudanças estão em curso com a perspectiva de implantação do Polo de Anchieta, e sua compreensão é fundamental para a tomada de decisões que criem condições objetivas de qualificar 
e monitorar o ambiente vivido cotidianamente. Um objeto técnico de magnitude como o Polo Anchieta deverá promover profundas alterações no cotidiano do lugar. Essa condição é ambígua, pois provoca o estranhamento do cidadão, colocando o indivíduo diante de situações sempre cambiantes. Com isso, produzem-se, contraditoriamente, dois fenômenos a partir da relação cidadão lugar/ mundo: de um lado, o estranhamento - como produto tanto da perda dos referenciais da vida e quanto da criação de novos padrões universais - e, de outro, o reconhecimento - como produto da constituição de identidades espaciais que se gestam no plano do vivido (CARLOS,1996, p.66). O Polo Anchieta, como objeto técnico de relevância a ser implantado na pequena cidade de Anchieta, impõe ao lugar a concretude das redes técnicas, reorganizando-o a partir dos desdobramentos do global.

\footnotetext{
A autonomia de existência do objeto técnico, isto é, a realidade que vem de suas capacidades funcionais absolutas, não pode ser confundida com a relatividade de sua existência histórica. É o lugar que atribui às técnicas o princípio da realidade histórica, relativizando o seu uso, integrando-as num conjunto de vida, retirando-as de sua abstração empírica e lhes atribuindo efetividade histórica.
}

(SANTOS, 2008,p.58)

O Polo Anchieta muda a trama das relações já estabelecidas e consolidadas. Por outro lado, dependendo da forma como seja conduzido o processo de implantação do Polo, este poderá proporcionar um distanciamento do cotidiano do lugar, sobrecarregando as estruturas existentes e distorcendo os significados incorporados historicamente, conforme será visto nos próximos capítulos. O modelo econômico globalizante tende a reproduzir-se, ainda que mostrando tipologias específicas, ligadas à natureza dos objetos técnicos produzidos e à resistência do espaço preexistente. No entender de Santos, "O modelo econômico é planejado para ser, em sua ação individual, indiferente a seu entorno" (SANTOS, 2006, p.107). Devemos reconhecer que o novo panorama a ser implantado com a diversificação da economia para novos polos industriais não decorre de simples mudança de forma, mas, certamente de uma "mudança de estado", similar ao fenômeno já ocorrido na RMGV. 


\subsection{As dinâmic as socioespaciais na região de influência do Polo}

O município de Anchieta compõe, juntamente com os municípios de Alfredo Chaves, Iconha, Itapemirim, Piúma e Marataizes, a Microrregião Expandida Sul (Figura 32) que faz limite com a Região Metropolitana de Vitória ${ }^{80}$. O município é composto por quatro distritos, dois dos quais estão no litoral - distrito sede e Iriri; os distritos de Jabaquara e Pongal situam-se na zona rural (Figura 33), onde a atividade agropecuária se destaca. Além dessas vilas, há pequenas comunidades rurais no interior.

Anchieta configura uma das ocupações mais antigas do Espírito Santo. A cidade sede está localizada ao sul do Espírito Santo, a 71 quilômetros da capital de Vitória. O lugar nos remete, num primeiro momento, a estabelecer vínculos imediatos com os primórdios da civilização brasileira, quando, no século XVI ${ }^{81}$, o Padre José de Anchieta chegou ao Espírito Santo para sua missão evangelizadora. Parte de sua vida se desenrolou na paisagem do litoral sul do Espírito Santo, mais precisamente na antiga aldeia de Riritiba ${ }^{82}$, onde veio a falecer. A história religiosa e suas simbologias culturais sempre foram marcantes na cidade.

Com uma área territorial de aproximadamente $420 \mathrm{~km}^{2}$, o município de Anchieta faz divisa com Guarapari e com Alfredo Chaves, ao norte, Piúma, ao sul; Iconha e Alfredo Chaves a oeste; com o Oceano Atlântico a leste (Figura 32). A dinâmica populacional de uma região reflete, de maneira direta, a sua dinâmica econômica. Aualmente, com uma modesta população estimada em torno de 20.226 habitantes $^{83}$ que representa somente $0,62 \%$ da população total do Estado e uma extensão territorial de $418,1 \mathrm{~km}^{2}$ - ou $0,9 \%$ do território espírito-santense -, o município possui a diminuta densidade demográfica de 45,9 habitantes por $\mathrm{km}^{2}$. De acordo com dados oficiais, 11 grandes propriedades rurais ocupam $27 \%$ do terri-

80 O estado do Espírito Santo está dividido em quatro macrorregiões administrativas e doze microrregiões, sendo que uma delas é a Microrregião Expandida Sul, vizinha à Metropolitana da Grande Vitória.

81 Sobre a data precisa de sua fundação, os historiadores divergem:" “fala-se em 1565, 1567 e 1579, mas sempre no dia 15 de agosto desses anos"(SANTOS NEVES e outros, 1995, p. 18).

82 Enquanto durou a presença jesuítica no país, o aldeamento de Riritiba foi um dos mais importantes do litoral sul, situado às margens do rio Benevente e ao sul de Guarapari. Com a expulsão dos jesuítas, Riritiba tornou-se, em 1759, a Vila Nova de Benevente, e posteriormente, em 1883, recebe a denominação de Anchieta em homenagem ao seu mais ilustre habitante.

83 Fonte: IBGE, ano referência 2009. 
RG.32

A região do Pólo Anchieta vizinho à Região Metropolitana da Grande Vitória. Observa-se que há uma continuidade quanto às localizações de objetos técnicos ao longo do litoral, considerando desde Anchieta passando pela R.M.G.V até o município de Aracruz. Fonte: IJ SN

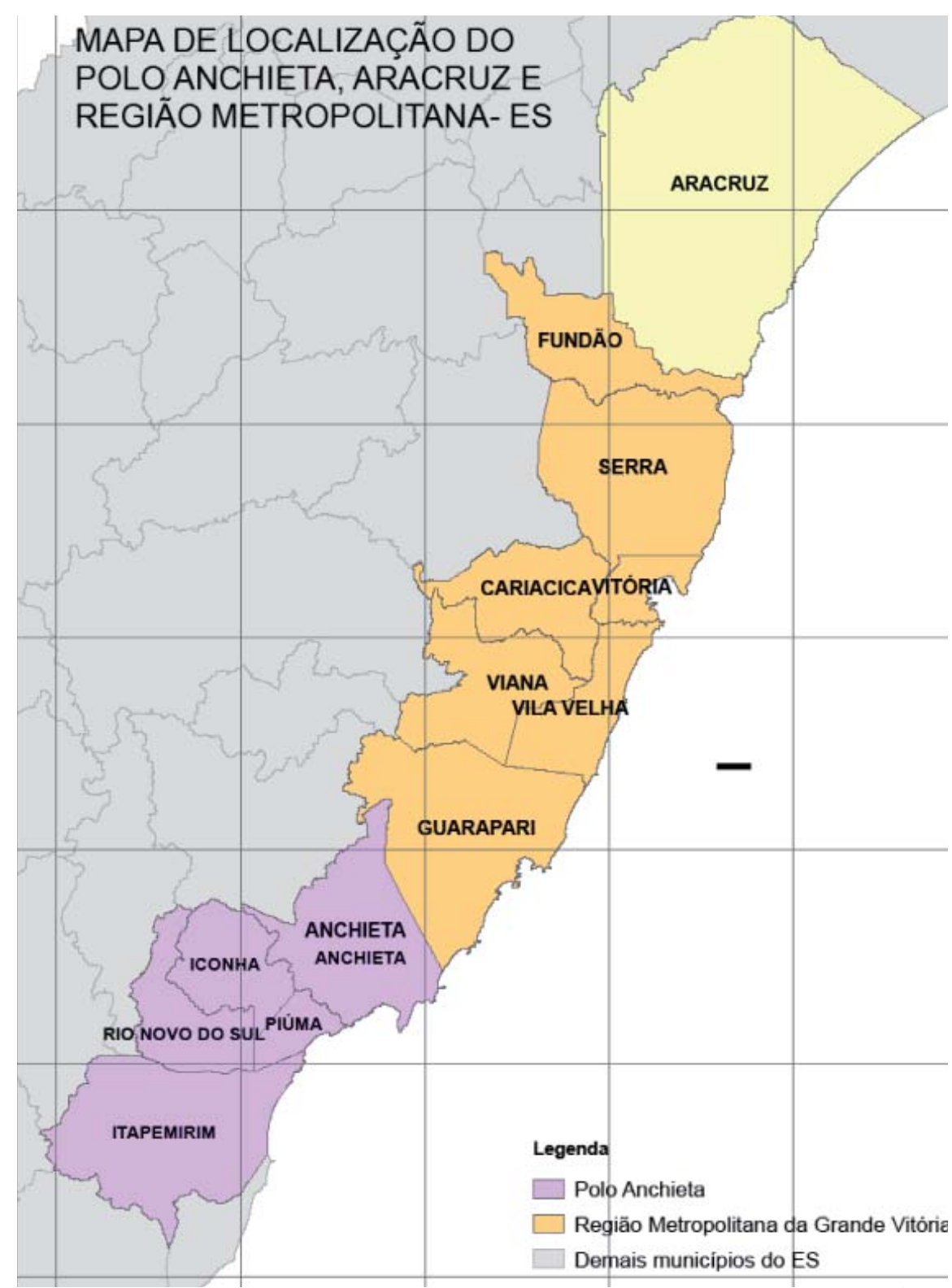

Tabela 11

FG.32

\begin{tabular}{l|c|c|c|c}
\hline \multirow{2}{*}{\multicolumn{1}{c|}{ Disc riminação }} & \multicolumn{2}{c|}{2000} & \multicolumn{2}{c}{2007} \\
\cline { 2 - 5 } Total & $\mathbf{1 9 . 1 7 6}$ & $\mathbf{1 0 0 , 0 0}$ & $\mathbf{1 9 . 4 5 9 *}$ & $\mathbf{1 0 0 , 0 0}$ \\
\hline Homens & 9.738 & 50,78 & 9.807 & 50,82 \\
\hline Mulheres & 9.438 & 49,22 & 9.491 & 49,18 \\
\hline Urbana & 13.211 & 68,89 & 13.686 & 70,33 \\
\hline Rural & 5.965 & 31,11 & 5.773 & 29,67 \\
\hline
\end{tabular}

Fonte: IBGE. Censo Demográfico 2000. IBG E. Contagem da População 2007. Elaboração: IJ SN. Nota: (*) Inc lusive a população estimada nos domic ílios fechados. 
Tabela 12

Dados sobre Popula ção, Área e Densidade Demográfica, Metropolitana Expandida Sul - 2000

\begin{tabular}{l|c|c|c|c|c}
\multicolumn{1}{c}{ Municípios } & Urbana & Rural & Total & Área (km²) & $\begin{array}{c}\text { Densidade demográfica } \\
\text { (Habitante/ } \mathbf{~ k m}^{\mathbf{2}}\end{array}$ \\
\hline Alfredo Chaves & 5.614 & 8.002 & 13.616 & 615,59 & 22,12 \\
\hline Anchieta & $\mathbf{1 3 . 2 1 1}$ & $\mathbf{5 . 9 6 5}$ & $\mathbf{1 9 . 1 7 6}$ & $\mathbf{4 0 4 , 8 8}$ & $\mathbf{4 7 , 3 6}$ \\
\hline Iconha & 4.793 & 6.688 & 11.481 & 202,92 & 56,58 \\
\hline Itapemirim & 16.133 & 11.988 & 28.121 & 557,16 & 50,47 \\
\hline Marataízes & 23.378 & 6.847 & 30.603 & $\mathbf{1 3 4 , 9 6}$ & $\mathbf{2 2 6 , 7 6}$ \\
\hline Piúma & 14.089 & 886 & 14.987 & $\mathbf{7 2 , 9 4}$ & $\mathbf{2 0 5 , 4 7}$ \\
\hline Total & $\mathbf{7 7 . 2 1 8}$ & $\mathbf{4 0 . 3 7 6}$ & $\mathbf{1 1 7 . 9 8 4}$ & $\mathbf{1 . 9 8 8 , 4 5}$ & $\mathbf{5 9 , 3 3}$ \\
\hline
\end{tabular}

Fonte: IBGE (2000)

tório, enquanto que 358 minifúndios apenas 7,7\%. A empresa SAMARCO

Mineração é grande proprietária de terras no município de Anchieta.

A tabela 12 mostra que os municípios de maior população são, respectivamente, Marataízes, Itapemirim e Anchieta. A tabela destaca ainda que a população urbana excede a rural nessa Microrregião, especialmente em Marataízes, Itapemirim e Piúma. Os municípios de maior extensão territorial são, nessa ordem, Alfredo Chaves, Itapemirim e Anchieta. Em virtude disso, eles são também os municípios de menor densidade demográfica. $\mathrm{Na}$ verdade, a região apresenta pouco adensamento populacional: aproximadamente 59 habitantes por $\mathrm{km}^{2}$, provavelmente reflexo da escassez de atividades produtivas em alguns desses municípios.

A cidade de Anchieta, até a década de 1960, enquanto teve apenas o rio e o mar como principal via de transporte e comunicação, manteve o seu relativo isolamento no contexto estadual, com uma economia caracterizada por uma agricultura pouco diversificada e um turismo incipiente. Entretanto, quando se construíram as principais vias de acesso ao litoral sul do ES, BR 262, BR 101, e especialmente a rodovia estadual ES 060, mudaram-se as dinâmicas que favoreceram a acessibilidade aos municípios litorâneos. A ES 060 se tornou marco fundamental para a expansão urbana, mesmo que ainda incipiente, tendo a atividade do turismo estimulado o processo de urbanização para a orla.

FG.33

Divisão Distrital do município de Anchieta. Fonte: PDM de Anchieta. 


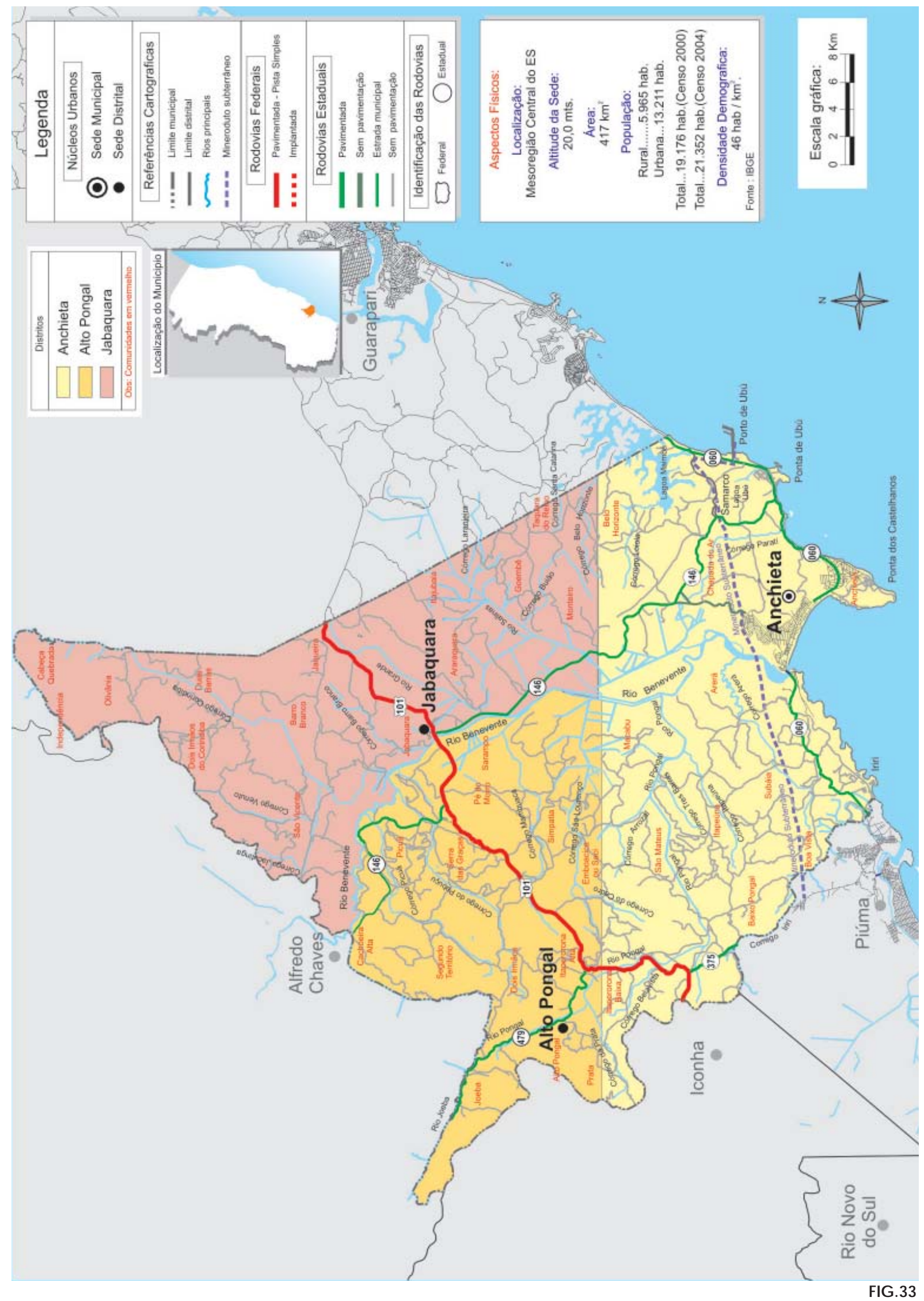




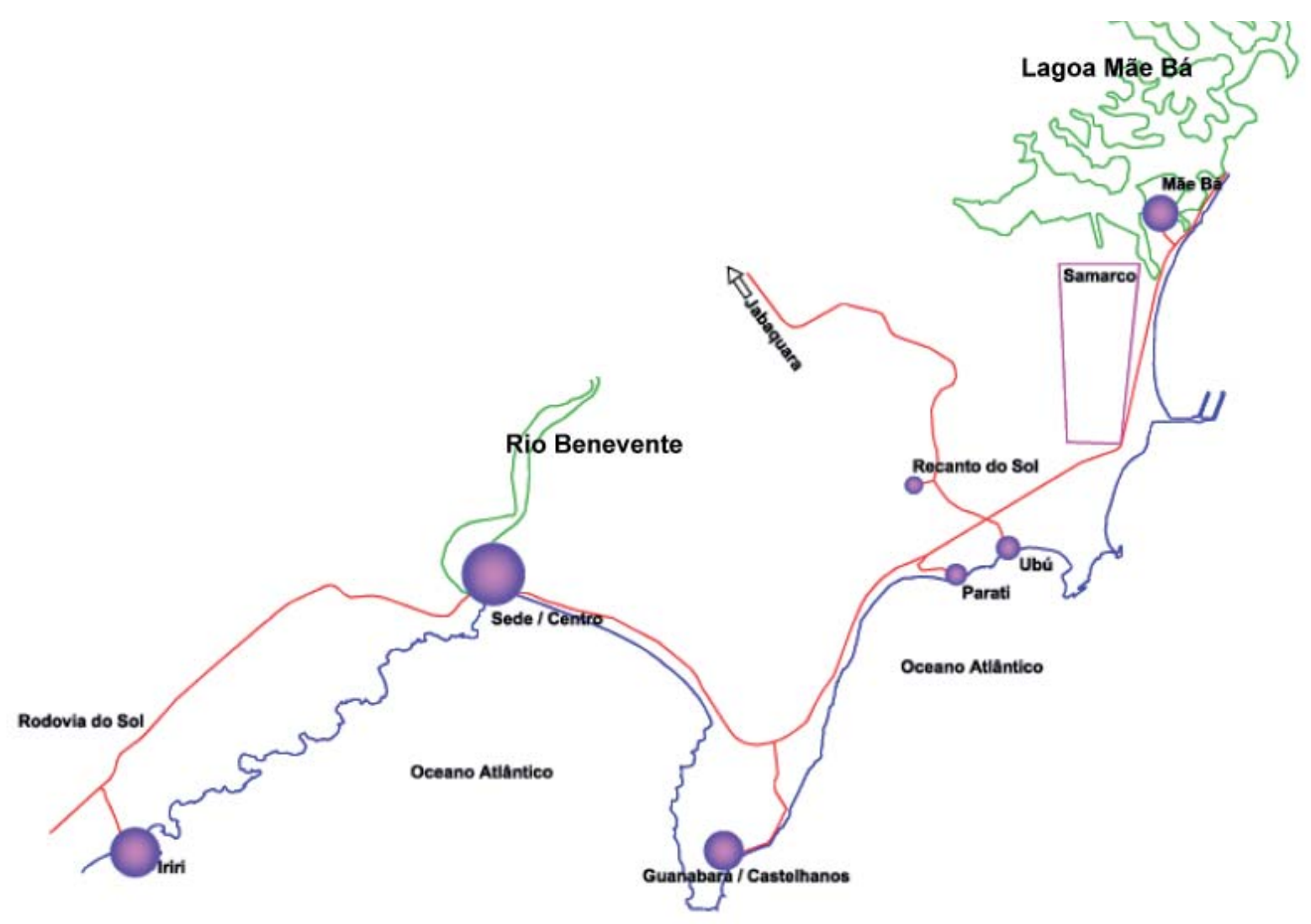

FG.34

RG.34

A expansão urbana se deu ao longo da estrada, por loteamento ou por ocupação espontânea, no sentido de Anchieta para Guarapari, especialmente Estrutura Urbana Linear Polinucleada. Fonte: ESPAÇO CONTRUÇÃO. Estudos PDM de Anchieta em direção aos balneários de Iriri e Ubu, Parati e Castelhanos: primeiramente nas áreas de restingas e, em seguida, pela expansão, nas enseadas e nos terrenos de tabuleiros. Um condicionante que favoreceu a procura por novas áreas para a expansão além da sede de Anchieta foi o fato de sua praia não ser favorável ao uso pelos banhistas, em virtude da proximidade com a foz do Rio Benevente ${ }^{84}$. Atualmente, Anchieta apresenta, devido às características físicas de seu sítio urbano, da ES $060^{85}$ e da expansão imobiliária, setores consolidados de uma estrutura urbana linear polinucleada, com clara tendência em continuara a expansão em direção à orla litorânea.

Conforme a tabela 13, o município de Anchieta possui uma taxa de urbanização de $69 \%$, sendo a variação do crescimento, no período entre

84 A praia da cidade de Anchieta apresenta areia escura e a coloração da água barrenta.

85 A ES 060 tem caráter de via urbana e rodovia, e o aspecto positivo dessa situação é condicionar o fluxo da rodovia por dentro da malha urbana, o que possibilita dinamismo ao setor comercial. Porém, uma das consequências negativas desta condição é o congestionamento e sobrecarga das vias em épocas de pico do fluxo turístico, misturando o tráfego local com o de passagem. 
Tabela 13

Taxa de urbaniza ção

\begin{tabular}{l|c|c|c|c|c|c|c}
\hline \multicolumn{1}{c|}{ MUNICíPIO } & $\mathbf{1 9 7 0}$ & $\mathbf{1 9 8 0}$ & $\mathbf{1 9 9 1}$ & $\mathbf{1 9 9 6}$ & $\mathbf{2 0 0 0}$ & $\mathbf{2 0 0 7}$ & $\begin{array}{c}\text { VARIAÇÃO TAXA DE } \\
\text { URBANIZAÇÃO 1991-2000 }\end{array}$ \\
\hline Gua rapari & 46,7 & 83,5 & 89,4 & 91,8 & 93,4 & 94,8 & 4,4 \\
\hline Anchieta & $\mathbf{1 9 , 9}$ & $\mathbf{5 3 , 7}$ & $\mathbf{5 8 , 9}$ & $\mathbf{6 4 , 5}$ & $\mathbf{6 8 , 7}$ & $\mathbf{7 0 , 3}$ & $\mathbf{1 7}$ \\
\hline Piúma & $\mathbf{6 3}$ & $\mathbf{7 3 , 5}$ & 90,8 & 93,5 & 94,1 & 94,7 & 3,6 \\
\hline Total Estado & $\mathbf{4 5 , 2}$ & $\mathbf{6 3 , 9}$ & $\mathbf{7 4}$ & $\mathbf{7 7 , 6}$ & $\mathbf{7 9 , 5}$ & & \\
\hline
\end{tabular}

Fonte: IBG E- Censos Demográfic ose Contagem População

os anos de 1991 e 2000, de 17\%, o que indica um aumento considerável na urbanização, provavelmente em virtude dos empregos gerados com a instalação da SAMARCO Mineração. Já o município de Piúma se destaca por apresentar, tanto no ano de 1991 como no de 2000, valores superiores a 90\%. O município de Guarapari aproxima-se desse valor em 1991, com cerca de $89 \%$, e o supera no ano de 2000, atingindo cerca de $93 \%$. Se procedermos à análise comparativa entre esses municípios, observaremos que Anchieta ainda apresenta o menor índice de urbanização em relação aos municípios vizinhos, o que pode ser explicado pelo fato de a sede não dispor de muitas áreas para expansão, visto que grande área do território é de propriedade da empresa SAMARCO. Segundo informações do setor de Cadastro da Prefeitura Municipal de Anchieta, a Samarco Mineração é proprietária de 7.846,957 ha ,correspondendo a aproximadamente 18,69\% da área urbana do território de Anchieta (Figura 35$)^{86}$. A implantação da SAMARCO e do Terminal portuário no fim da década de 1970, favoreceu a migração e o surgimento de bairros localizados próximos à empresa, mas a ocupação se estendeu, preferencialmente, para os municípios vizinhos de Piúma e Guarapari.

Apesar de os municípios de Anchieta, Guarapari e Piúma serem espacialmente contíguos e litorâneos, podem ser detectadas diferenças em suas estruturas produtivas e ocupacionais. Essas diferenças podem ser atribuídas ao fato de que, apesar de o município de Anchieta ter certa representatividade no setor secundário, a população economicamente ativa está concentrada mais na área rural, em atividades voltadas para agricultura. As propriedades consideradas rurais ocupam grande parte do território de Anchieta e podem ser categorizadas em grandes, médias, pequenas 


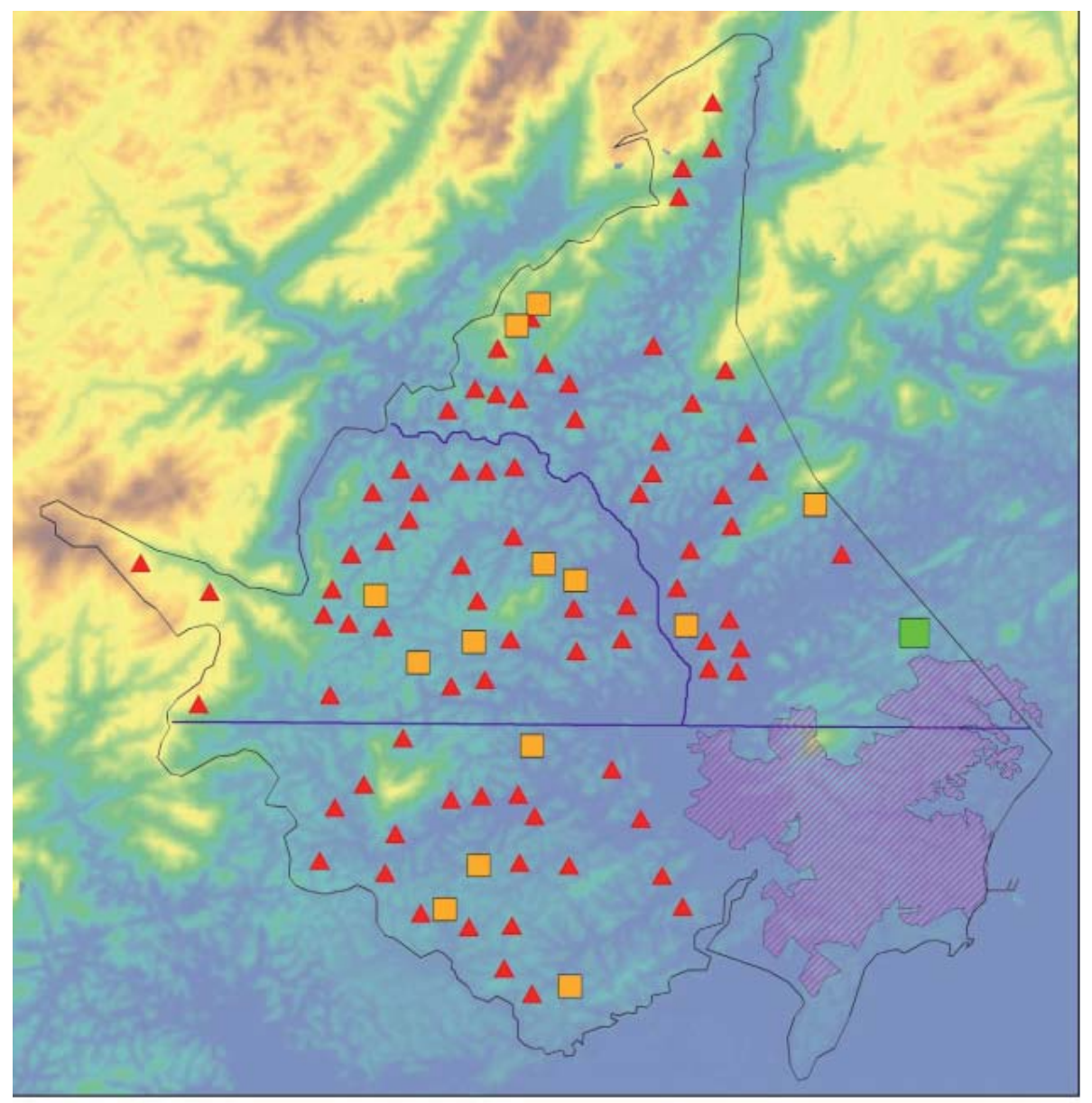

RG.35

Estrutura Fundiária do muncípio de Anchieta. Fonte: ESPAÇO CONTRUTORA. Estudos PDM de Anchieta

\section{Legenda}

Minifundio e pequenas propriedades

Outras grandes propriedades

A Médias propriedades

áreas da Samarco

propriedades e minifúndios. Em virtude de a concentração fundiária no perímetro urbano estar nas mãos da empresa Samarco, a urbanização do distrito-sede ainda é incipiente, e a expansão das áreas habitacionais distribui-se pelos municípios vizinhos.

Em geral, no que se refere à geração de renda, os municípios do litoral sul tem no turismo a sua principal referência, destacando-se os municípios de Anchieta, Marataízes e Piúma. Entretanto, esta potencialidade não é explorada em sua integralidade devido a carências de infraestrutura hoteleira. Constituída de pequenos meios de hospedagem, de alimentação e de equipamentos sazonais, o turismo local é pouco estruturado em seus serviços. Acostumados a uma rotina de veranistas em períodos de alta e 
baixa temporada, os municípios não estão preparados para uma ocupação constante e a um nível de exigência qualitativa para o turismo de negócios.

As demais atividades do mercado de trabalho, a prestação de serviços e a pesca ocupam o restante da população economicamente ativa. As informações históricas indicam claramente que a pesca sempre desempenhou um papel de primeira importância na vida das comunidades litorâneas e já está incorporada à cultura do município. A atividade pesqueira congrega cerca de 600 famílias, com uma produção média em torno de 2.800 ton / ano. Estima-se um número de 1.250 pescadores profissionais ligados diretamente à atividade de captura, distribuídos nas sete comunidades existentes no litoral do município. Os demais operam próximo à costa, interferindo na migração de cardumes para desova e crescimento. Com o objetivo de ocupar os pescadores nos períodos de defeso - a produção de camarão tem caído, nos últimos anos, devido à pesca predatória nos três meses de proibição. Foi criado, em Anchieta, o Projeto Maricultura ${ }^{87}$ como alternativa de dinamizar o mercado de trabalho.

Considerados estes aspectos da economia tradicional, podemos afirmar que, no curso de sua história, a região do litoral sul pouco participou dos principais momentos do desenvolvimento do Espírito Santo e sempre esteve à margem de todo o processo de crescimento econômico e social do estado. A ausência da região no processo de industrialização capixaba, iniciado na década de1970, centrado principalmente na Região da Grande Vitória, e a perda de dinamismo da economia cafeeira, com consequente redução na produção estadual, foram alguns dos fatores que determinaram o recuo na projeção dos indicadores econômicos no contexto estadual. Uma das consequências mais importantes desse processo é demonstrada pela fragilidade ou mesmo pela ruptura da governabilidade local e regional diante de processos hegemônicos que ocorriam no território estadual. Daí a decorrente dificuldade, enfrentada pelos poderes locais, em exercer

87 O Projeto Maricultura foi incluído no Projeto de Execução Descentralizada (PED), do Ministério do Meio Ambiente, com a coordenação estadual da Secretaria Estadual de Meio Ambiente (SEAMA) e execução pela Prefeitura Municipal de Anchieta (PMA) e ONG’s estaduais, trata-se de uma atividade alternativa de geração de emprego e renda, com a implantação de um sistema de cultivo de mexilhões nas proximidades da costa do município. Em 1998 já haviam sido implantados nove módulos duplos, com bons resultados. Quanto ao beneficiamento e à comercialização, pensase na Escola de Pesca de Piúma, que tem estrutura para tanto. Técnicos da área apontam outras alternativas, como o cultivo de camarões em fazendas marinhas e de ostras nativas em estuários. Fonte: Prefeitura Municipal de Anchieta. 
funções de articulação e condução de um processo de desenvolvimento regional menos díspar. A falta de expressividade desses municípios culminou na carência de serviços e na estagnação econômica, de maneira geral, disseminando-se uma série de problemas políticos que impactaram diretamente no contexto social, como, por exemplo, as práticas patrimonialistas e clientelistas.

A saída para a crise do modelo agrário, perseguida pela elite local de Anchieta, favoreceu a instalação da indústria de pellets da SAMARCO ${ }^{88} \mathrm{em}$ 1977. A SAMARCO é uma empresa de lavra, beneficiamento, transporte, pelotização e exportação de minério de ferro, cujas instalações industriais estão localizadas em dois estados: em Minas Gerais, situam-se as operações de lavra e beneficiamento; no Espírito Santo, especificamente em Anchieta, encontram-se a planta de pelotização e o Porto de Ubu, de onde a totalidade da produção é exportada.

Até a época da instalação da SAMARCO, Anchieta apresentava-se como um município de pouco dinamismo, sustentando-se através de uma agricultura tradicional e pouco diversificada, de um turismo incipiente e de um comércio cujo alcance não ultrapassava suas fronteiras. Com a instalação da SAMARCO, Anchieta passou a ocupar um lugar representativo no estado com uma das maiores participações no setor secundário do PIB estadual (VA por setor:33,80\%). Apesar de a participação no PIB do estado ser pouco expressiva $(2,9 \%)$, se considerarmos o PIB relativo por setor, o município de Anchieta ocupa o terceiro lugar no ranking do estado no setor secundário que envolve as atividades de Indústria Extrativa Mineral e de Transformação, Construção Civil e Geração e Distribuição de Eletricidade, Gás Canalizado, Água e Esgoto ${ }^{89}$. Entretanto, apesar do aumento da projeção no PIB relativo do estado, a riqueza gerada não foi revertida na estrutura urbana e social, ou mesmo, não tem contribuído para uma distribuição mais qualitativa na renda da população local.

88 A Samarco tem capacidade instalada para produzir e comercializar 14 milhões de toneladas/ano de pelotas de minério de ferro e 1 milhão de toneladas/ano de finos de minério (pellet feed e sinter feed). Seus recursos minerais são da ordem de 4 bilhões de toneladas, que asseguram o suprimento de minério de ferro por pelo menos 50 anos, ao ritmo de produção atual. A empresa possui um dos maiores minerodutos do mundo para transporte de minério de ferro, com $396 \mathrm{~km}$ de extensão, utilizado para transportar a polpa de minério de ferro entre suas duas unidades industriais.

89 Fonte: Perfil Básico Anchieta. IJSN, 2008. 
Tabela 14

PIB a preçosconstantes* para a Mic rorregião Metropolitana Expandida Sul

\begin{tabular}{l|c|c|c|c|c|c|c|c|c}
\hline Municípios & $\mathbf{1 9 7 0}$ & $\mathbf{1 9 8 0}$ & $\begin{array}{c}\text { TCG } \\
\mathbf{1 9 8 0} \\
\mathbf{1 9 7 0}\end{array}$ & $\mathbf{1 9 8 5}$ & $\mathbf{1 9 9 6}$ & $\begin{array}{c}\text { TCG } \\
\mathbf{1 9 9 6} \\
\mathbf{1 9 8 5} \text { (\%) }\end{array}$ & $\mathbf{2 0 0 2}$ & $\begin{array}{c}\text { TCG } \\
\mathbf{2 0 0 2}- \\
\mathbf{1 9 7 0} \text { (\%) }\end{array}$ & $\begin{array}{c}\text { \% } \\
\text { relativo } \\
\mathbf{e m} \mathbf{2 0 0 2}\end{array}$ \\
\hline $\begin{array}{l}\text { Alfredo } \\
\text { Chaves }\end{array}$ & 19.055 & 45.784 & 8,3 & 101.803 & 57.744 & 1,95 & 70.942 & 4,06 & 3,96 \\
\hline Anchieta & $\mathbf{1 7 . 7 7 0}$ & $\mathbf{5 0 7 . 3 4 8}$ & $\mathbf{3 5 , 6 2}$ & $\mathbf{6 4 3 . 7 1 2}$ & $\mathbf{2 3 0 . 6 3 8}$ & $\mathbf{- 6 , 3 6}$ & $\mathbf{1 . 1 4 8 . 4 4 8}$ & $\mathbf{1 3 , 4 6}$ & $\mathbf{6 4 , 1}$ \\
\hline Iconha & 13.577 & 65.375 & 15,36 & 63.076 & 52.029 & $-1,88$ & 83.079 & 5,64 & 4,64 \\
\hline Piúma & 3.576 & 13.782 & 13,05 & 20.040 & 32.506 & 7,41 & 109.656 & 10,93 & 6,12 \\
\hline Itapemirim & 61.801 & 204.287 & 11,48 & 191.004 & 198.833 & $-0,23$ & 211.225 & 3,79 & 11,79 \\
\hline Marataízes & - & - & - & - & - & - & 168.213 & - & 9,39 \\
\hline
\end{tabular}

Fonte: IBGE e IJ SN.

*Valores, em mil rea is, ajustados pelo IG P-DI de 2004.

Tábela 15

Produto intemo bruto - Município de Anchieta 2005 por setor (\%)

\begin{tabular}{l|c|c}
\multicolumn{1}{c|}{ Discriminação } & Município & Estado \\
\hline PIB total a preços de mercado (R\$ mil) & 1.357 .981 & 47.190 .914 \\
\hline PIB per capita (R\$ 1,00) & 62.196 & 13.846 \\
\hline VA por setor (\%) & & $8,80 \%$ \\
\hline Primário & $1,56 \%$ & $\mathbf{3 3 , 8 0 \%}$ \\
\hline Secundánio & $\mathbf{7 2 , 2 8 \%}$ & $57,50 \%$ \\
\hline Terciánio & $26,16 \%$ & \\
\hline
\end{tabular}

Fonte: IBGE/IJ SN

Elaboração: IJ SN - Coordenação de Economia e Desenvolvimento

Analisando-se as tabelas 14 e 15, observa-se que a concentração do PIB está na região sede de Anchieta, resultado da localização da SAMARCO S.A. Ainda no aspecto econômico, a tabela 14 mostra a evolução do PIB a preços constantes, bem como a participação relativa de cada município na produção de riqueza na região. $\mathrm{Na}$ tabela, fica evidente o significativo incremento econômico de Anchieta: cerca de 13,46\% ao ano no período 1970-2002. Em seguida, vem Piúma, com uma variação positiva de quase $11 \%$ ao ano em igual período. O município de Anchieta perfaz $72,28 \%$ da composição do PIB no setor industrial, o que mostra o setor secundário do município como responsável por uma maior arrecadação de tributos para o município, conforme mostra a tabela 15 . 


\subsubsection{Saneamento básico}

A população do município de Anchieta é abastecida a partir de captação localizada no rio Pongal, afluente da margem direita do rio Benevente. $\mathrm{O}$ abastecimento de água de Guarapari apresenta disponibilidades e demandas normais a partir de captações nos rios Jaboti e Conceição. Em ocasiões nas quais são previstos déficits hídricos na utilização destes mananciais, como ocorre em intervalos de tempo de seca, que coincidam com a época de maior afluência de turistas à cidade, o abastecimento é complementado com água captada no rio Benevente(Anchieta), na localidade de Jabaquara, situada próximo da rodovia BR-101 (AAE, 2008) ${ }^{90}$.

A disponibilidade hídrica total dos dois mananciais não apresentam problemas significativos quanto à quantidade e à qualidade da água disponível para suprimento das demandas. As condições de abastecimento de água dos outros setores localizados na área urbana de Anchieta, tais como os balneários de Iriri e Ubu, atendem satisfatoriamente à demanda. Aproximadamente $95 \%$ da população residente na área urbana de Anchieta é beneficiada pelo abastecimento de água tratada por meio do sistema implantado e explorado pela CESAN - Companhia Espírito Santense de Saneamento. Entretanto, o sistema integrado - Iriri, Ubu e Piúma - não abastece os bairros de Praia dos Castelhanos e Mãe-Bá. Na área rural, o abastecimento da população ocorre por meio de pequenos sistemas de abastecimento, denominados PRÓ-RURAL - Programa de Saneamento Rural.

Considerando a prioridade legal do abastecimento público e da dessedentação de animais, a localização prevista para a implantação do Polo Industrial e de Serviços de Anchieta, na parte baixa do rio Benevente, próxima ao seu estuário, é outro fato que corrobora com a previsão de que os cenários e as previsões futuras relativas ao indicador Disponibilidade/ Demanda para os municípios de Anchieta, Guarapari e Piúma tendem a se alterar. Os estudos apontam que os valores estimados para o aumento da demanda evidenciam a necessidade de implementação de ações que

90 AAE: Avaliação Ambiental Estratégica é um instrumento de avaliação de impactos relativo ao Polo Industrial e de Serviços, contratado pelo movimento empresarial ES em AÇÃO. Os resultados do AAE foram publicados no final de 2008. 
possibilitem acréscimo nos valores de disponibilidade hídrica no possível ponto de captação de água no rio Benevente e/ou utilização adicional de água proveniente de outros mananciais visando atender às demandas futuras previstas até o ano de $2018^{91}$.

A situação atual no que diz respeito à coleta e tratamento de esgotos domésticos no município é o item em que se observam mais problemas quanto às deficiências do serviço prestado à população. Em Guarapari, por exemplo, das 5.538 economias, apenas 517 ligações de coleta de esgoto são realizadas, o que é muito pouco, considerando o município como principal balneário do estado, sendo feito o lançamento desses efluentes nos corpos receptores naturais sem nenhum tipo de tratamento prévio.

Com relação a Anchieta, atualmente a CESAN está construindo, em parceria com a Prefeitura de Anchieta, uma parte do sistema de esgoto sanitário da área central da cidade. Com a implantação dessa primeira etapa, deverão ser atendidos, com coleta e tratamento, aproximadamente 25\% (vinte e cinco por cento) dos imóveis existentes nessa área do distrito sede. O projeto de engenharia do sistema em implantação foi elaborado visando cobrir $100 \%$ dessa área, ficando a concessionária com a responsabilidade de buscar recursos para a ampliação do sistema.

O balneário de Iriri, localizado ao sul da sede distrital, conta com um sistema público de esgoto sanitário completo, com coleta e tratamento, com cobertura implantada de quase 100\%, mas somente cerca de 64\% (sessenta e quatro por cento) dos imóveis foram interligados às redes coletoras existentes (AAE, 2008, p.146). Já em Ubu, a ETE atende a 60\% dos domicílios. Para a localidade de Mãe-Bá, situada no norte da cidade, fazendo limite com Guarapari, a prefeitura contratou o projeto do sistema de esgoto, já analisado pela CESAN, sendo a SAMARCO Mineração responsável pela sua implantação pelo Termo de Ajuste e Conduta (TAC).

Um grave problema que atinge Anchieta e seus balneários é com relação ao lençol freático alto. A prefeitura tem dois caminhões limpa fossa que

91 Os estudos foram realizados para estimar vazões de referência de vazões mínimas para o rio

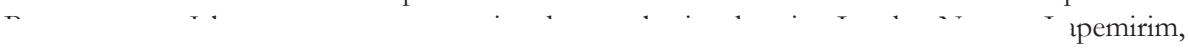
mais próximas do Pólo Industrial e de Serviços de Anchieta. Os resultados serão apresentados no capítulo seguinte (Riscos e Vulnerabilidades). 
trabalham direto, recolhendo o esgoto que é jogado na ETE de Piúma, o que causa sérios problemas para a operação dessa estação pelo grande volume de material depositado. No verão, a situação se agrava porque, além do número maior de pessoas, as chuvas nesse período ocasionam o rápido enchimento das fossas.

\subsubsection{Do sistema viánio}

O sistema viário municipal de Anchieta, seja no âmbito rural seja no urbano, já é considerado deficitário no que diz respeito à qualificação das suas vias e à incapacidade de atendimento à demanda gerada no período sazonal de turismo. Nas áreas urbanas, essa situação é compactuada pela não aplicabilidade da legislação urbanística adequada, consubstanciada em plano diretor, e, também pela falta de fiscalização. A municipalidade sempre manteve uma postura distanciada, ou mesmo, complacente com as determinações do empreendedor do parcelamento do solo (loteamento) ou com as ações espontâneas da população, tais como desmembramentos ou edificações ilegais. Como não há estacionamento regulamentado, há um sem- número de edifícios sem garagem (prédios aprovados com garagem, mas na implantação, essas garagens viram comercio). Essa situação gera grande quantidade de carros nas vias, o que prejudica muito o trânsito local, especialmente na alta temporada de verão.

No caso rural, verifica-se que a estrutura da rede viária não tem sido desenvolvida no sentido de atender às novas demandas ou como elemento de redirecionamento espacial e indutor de novas frentes de desenvolvimento. Em função disso, constata-se que boa parte da população das vilas, povoados e comunidades rurais, notadamente aquelas localizadas mais distantes da área central da cidade de Anchieta, acabam por realizar suas trocas e demandas cotidianas com as sedes de municípios vizinhos: Guarapari (que apresenta características de polo regional embrionário), Piúma, Iconha e Alfredo Chaves. A inexistência de vias de ligação direta entre a BR 101 e a sede de Anchieta e/ou de pontes entre uma margem e outra do Rio Benevente faz com que a população rural e as demais interessadas tenham que fazer grandes deslocamentos.

Diante da dificuldade de mobilidade da população rural, esta estabelece 
vínculos com a sede principalmente na demanda de serviços que institucionalmente só podem receber ou realizar na sede, tais como serviços cartoriais, das instituições judiciárias, atendimento pelo Sistema Único de Saúde (SUS), e serviços da administração municipal, dentre outros. Tal situação, também, ocorre entre as margens do rio Salinas, tributário da margem direita do Benevente, cuja bacia se localiza entre a Serra de Ubu e a BR 101. Segundo estudos do Plano Diretor Municipal (2006) e da Avaliação Ambiental Estratégica (2008), a rede viária existente em Anchieta não contribui para a estruturação socioeconômica do município, a saber:

- A quase totalidade das estradas, estaduais e federais, não apresentam leito adequado que garanta segurança e uma boa circulação em todas as estações do ano, chegando mesmo a ficar intransitáveis em época de chuvas intensas e nas temporadas de verão.

- A BR 101 apresenta capacidade de tráfego insuficiente para ampliação das demandas tráfego de caminhões, com problemas na pavimentação e manutenção, o que oferece sérios riscos aos motoristas que trafegam na rodovia.

- ES 060: capacidade de tráfego insuficiente para demanda adicional.

- A rede viária não está estruturada de modo a fortalecer o papel de centro urbano que a área central de Anchieta, potencialmente, deveria exercer, pois algumas vias possuem traçado que direcionam a população do município para cidades vizinhas (Iconha, Piúma, Alfredo Chaves e Guarapari), seja devido à proximidade das comunidades rurais a essas cidades, seja por não apresentarem boas condições de circulação no sentido da sede distrital de Anchieta.

- O grande entrave atual na circulação urbana de Anchieta, com perspectivas de sério agravamento em futuro relativamente próximo, é a superposição do tráfego de passagem da rodovia ES 060 (Rodovia do Sol) com ruas e avenidas locais, principalmente na área central da cidade, trazendo conflitos entre a circulação local de veículos e a de pedestres, já que, em muitos trechos, os passeios são mínimos ou praticamente inexistentes.

Mesmo fora da área central, principalmente na região dos balneários de 
Pontal de Castelhanos, Guanabara e próximo ao núcleo central de Iriri, a aprovação de parcelamento do solo para fins urbanos (loteamentos e desmembramentos) em desacordo com a legislação, não levando em conta as exigências legais de faixa non eadificandi / vias laterais ao longo das rodovias, principalmente da ES $060^{92}$, causa transtornos na estrutura urbana. Tal situação vem comprometendo a qualidade da circulação macrourbana, atual e futura, com perspectivas de ocorrências de grandes deseconomias e impactos adversos à qualidade de vida urbana.

Um dos principais problemas na circulação da área central da cidade está representado pela configuração da rodovia do Sol, que apresenta traçado estreito desfavorável, embora ainda exista possibilidade de soluções parciais e de abrangência de médio prazo por meio de constituição de binário de circulação. No longo prazo, além da falta de definição de um novo traçado para a Rodovia do Sol, para o qual são exíguas as possibilidades alternativas, esse problema deve se agravar. Cabe registrar que a hipótese mais viável de um traçado alternativo para a ES 060, representada pelo eixo definido pelo mineroduto da SAMARCO (travessia do rio Benevente), já apresenta pequeno indício de inviabilidade futura, representado pelos loteamentos aprovados próximo ao conjunto habitacional Nova Jerusalém. Nesse loteamento, inclusive, não foram consideradas adequadamente as exigências da lei federal e estadual de parcelamento do solo para fins urbanos.

Para alguns pontos da atual área urbana, vislumbram-se conflitos entre a expansão da malha urbana e os aspectos naturais de interesse ambiental/ paisagístico. Entre esses pontos, as áreas de manguezais ao longo do rio Benevente, as áreas situadas na porção oeste da ponta dos Castelhanos, áreas com topografia acidentada, e com cobertura florestal natural, situadas entre a foz do rio Benevente e Iriri. De um modo geral, chama atenção, em toda a área urbana, o fato de que os sistemas viários dos diversos loteamentos não possuem uma hierarquia que crie vias contínuas de maior porte para atender à circulação dos eixos primários, vias coletoras que acessem os bairros, assim como vias locais mais curtas, que ofereçam acesso às residências sem conflitos com o tráfego de passagem.

92 Para melhor visualização do sistema viário, recorra à figura $n^{\circ} 33$, referente aos distritos e sistemas viários. 
A industrialização do município atrairá mão de obra residente em algumas zonas tidas como rurais ou semiurbanas. A não existência de um sistema de transporte coletivo urbano eficiente e adequadamente gerenciado pelo poder público importará em prejuízos especialmente para essas populações, deixando-as fora dos benefícios do crescimento industrial do município. $\mathrm{O}$ atendimento insuficiente do serviço de transporte municipal acaba por gerar custos adicionais, como fretamento privado para transporte de funcionários, entre outros. O sistema urbano municipal é, na fase atual, praticamente inexistente e sem organização formal/institucional.

Em suma, em Anchieta, assim como ocorre na grande maioria dos municípios do país, a administração local não age previamente, no que tange à projeção ampliada da malha viária futura, isto é, não age no sentido de prever demandas futuras por melhores condições de mobilidade. Este quadro passa a ser preocupante quando associado ao crescimento que tem ocorrido no volume do tráfego de passagem em decorrência do desenvolvimento do turismo-veraneio na região e, principalmente, diante das reais perspectivas de crescimento das atividades econômicas centradas na área urbana, de origens exógenas ao município, especialmente na ocorrência da concentração efetiva de tecnologias ligadas ao Polo Industrial de Serviços, Ferrovia Litorânea Sul e à exploração de petróleo no litoral sul.

\subsection{A paisagem e os objetos localmente qualificados}

Na perspectiva de valoração dos objetos localmente qualificados, não há como deixar de ressaltar os símbolos que integram o patrimônio histórico, artístico e cultural, atribuindo valores e significados à região. Na perspectiva da história social, vale lembrar que, como linguagem, a arquitetura, o edifício, enfim, o objeto é representação, é signo da relação de conhecimento que se processa entre o homem, o espaço e o tempo. Em relação ao espaço, esse conhecimento se dá sempre que o homem intervém transformando o espaço por meio do projeto ou do uso cotidiano. Sendo signo do espaço, sua instabilidade está representada pelo próprio ciclo vital que o atinge; intervenção, vida útil, degenerescência são etapas do processo que caracterizam o objeto e a dinâmica de representação (ROWE E KOETTER,S.D; KRIER,1981, apud FERRARA,2000, p.104). 
A paisagem com seus respectivos símbolos culturais exige que se faça uma reflexão sobre a possibilidade de conjugar a materialidade a eventos técnicos de magnitude, num futuro próximo, e, nesse contexto, avaliar possíveis conflitos que envolvem comunidades tradicionais da região, especialmente conflitos no âmbito cultural e ambiental.

Os municípios afetados pelo Polo Industrial e de Serviços possuem características peculiares que os tornam atrativos. As cidades incorporam uma dimensão ambiental e social mais relevante na medida em que ainda preservam, de certa forma, seus monumentos culturais, históricos e naturais. Identificam-se, aqui, alguns referenciais de destaque na paisagem, especialmente aqueles situados nos municípios de Anchieta e Píuma, tais como, a rede hídrica, constituída por rios, lagoas e mangues, que, juntamente com seus atributos físico-culturais, lhe conferem um contexto particular no âmbito da região.

As belezas naturais da região, associadas ao legado histórico da ação jesuítica em Anchieta, expresso pelos monumentos arquitetônicos que integram o Patrimônio Histórico Artístico Brasileiro, compõem um cenário singular no estado do Espírito Santo ${ }^{93}$. Coexiste, contudo, com essa materialidade histórica, uma identidade sociocultural pouco consolidada da população local, com riscos de perda de referências, diante da grande contingência de investimentos econômicos e da probabilidade de grande migração com o advento do Polo Industrial.

As marcas da globalização são elementos que não só atingem a paisagem, mas que favorecem mecanismos de desconstrução e construção dessa mesma paisagem. A relativa autonomia do lugar, nesse processo, é substituída por crescente interdependência "funcional" à atividade produtiva, rompendo a relação histórica e localmente estabelecida entre sociedade e natureza. Nessa perspectiva, o Polo Anchieta respalda a tese de Leite:

Do ponto de vista da espacialização, o conjunto de fatores socioeconômicos produz uma paisagem marcada pela

93 O aldeamento jesuítico no Espírito Santo ocorreu no litoral e mais precisamente nas adjacências do município de Vitória: ao norte, o aldeamento de Nova Almeida e, ao sul, o aldeamento de Guarapari e Riritiba (Anchieta). Todos esses aldeamentos deixaram inscritos nas cidades marcos arquitetônicos representados por suas igrejas em pontos espetaculares de suas respectivas paisagens. 
instabilidade, porque resulta de um processo contínuo de construção/destruição/reconstrução de diferenciações e de hierarquias, desvalorizações e revalorizações de partes do território e de suas regiões.

(LEITE, 2006, p.11)

Na visão de Magnoli (1982), a paisagem não se coloca como mero suporte do sistema de ações, mas também como parte constituinte delas. Magnoli entende a paisagem como resultado da dinâmica entre processos sociais (e econômicos, políticos, culturais) e processos naturais. Pode-se, assim, dizer que a paisagem retrata o projeto social de cada lugar, categorizado no espaço e no tempo. A paisagem implica relações entre processos, relações sistêmicas e dialéticas; portanto, não se trata de uma abordagem restrita ao campo de entendimento sistêmico da geografia física ou da ecologia. A proposição conceitual de Magnoli é respaldada por Queiroga:

[...] a dinâmica da paisagem não apenas se transforma ao modificar-se o sistema de objetos, mas ao realizar-se o sistema de ações, a cada momento, isto é, aliás, parte mesmo da visibilidade que caracteriza intrinsecamente a paisagem. A dimensão perceptível é um dos elementos que torna a paisagem distinta das demais categorias internas do espaço - o lugar e o território.

(QUEIROGA, 2006, p.59)

A concepção de cultura e a de individualidade são quase sempre correlatas, mesmo porque todo valor atribuído a determinado objeto pelo indivíduo é, necessariamente, uma representação do vínculo social que é consubstancial a esse objeto. $\mathrm{O}$ indivíduo estabelece relações com a paisagem e lhe atribui significados, ou seja, apreende a diferença que se pode encontrar num conjunto de fatos rotineiros que, lidos na sua diferença, permitem transformar o hábito, a rotina em alguma coisa perceptível e de valor.

Frequentemente, imagem e imaginário se confundem enquanto categorias de análise sobre a cidade. Ambas produzem informação, mas se expressam de modo diverso. A construção da cidade deixa de ser unicamente uma resposta à necessidade de agregar valores da sociedade, passando da noção de "espaço-função" para “espaço-expressão" (ROLNIK,1992, p.29). Sem dúvida, a arquitetura e o traçado são um registro físico da lin- 
guagem não verbal da cidade e portadores de significados que designam e dão concretude à paisagem urbana. É a partir disso que as gerações tentam construir uma imagem de cidade -pela intervenção em seu meio físico -, o que revela como cada sociedade se projeta e constitui seu imaginário coletivo a partir de conexões simbólicas de um dado momento histórico, sua singular maneira de ver e fazer sua própria existência.

As cidades são objetos de mudanças constantes, por isso se faz necessário preservar as referências materiais nos quais se apoiam a memória individual ou a coletiva. Essas referências constituem um patrimônio, que pode ser histórico, paisagísttico, cultural e arquitetônico, ambiental, entre tantos outros. Para Sandeville (2004, p.2)," o termo patrimônio (do latim patrimonium) refere-se à res-familiaris, ao conjunto de pertences, derivado de pater, título de respeito dado a deuses ou heróis. Remete, portanto, à idéia de possessão, de herança (a continuidade pela transferência de uma posse, de uma autoridade)". A expressão patrimônio-paisagístico referese, a priori, a uma valoração. Uma paisagem que se torna patrimônio já é considerada diversa de outras, duplamente valorizada; por isso o olhar para ela irá presidido por categorias compatíveis com essa diferenciação que se lhe atribui. Na medida em que qualquer objeto ou paisagem sejam socialmente reconhecidos, esse reconhecimento pressupõe um mecanismo que os consagre, mesmo que ainda isso se dê de modo não unânime e controverso, pois trata-se de condições relativas a um quadro.

Para cada sociedade, para cada lugar, há um conjunto de bens (objetos) representativos da memória coletiva, que pressupõe uma identificação e um juízo de valor. Torna-se importante, para atribuição do juízo de valor, o papel que determinado bem cultural desempenha na construção das identidades coletivas, que esse bem valorize e retrate um determinado momento histórico. No sentido filosófico, valor é tudo aquilo que tem importância para o espírito. Entretanto, vale ressaltar, que novas questões até então não consideradas no contexto da valoração passam a direcionar os cuidados com objetos até então negligenciados, de que é exemplo a noção de patrimônio ambiental urbano, que incorpora novas categorias de bens como portadoras de valores de interesse comum. Resultam desse pensamento medidas de proteção que contemplam bairros, quadras, logradouros, para citar alguns. 
RG.36

Sítio histónico de Anc hieta às margens do Benevente. Fonte: Acervo pessoal

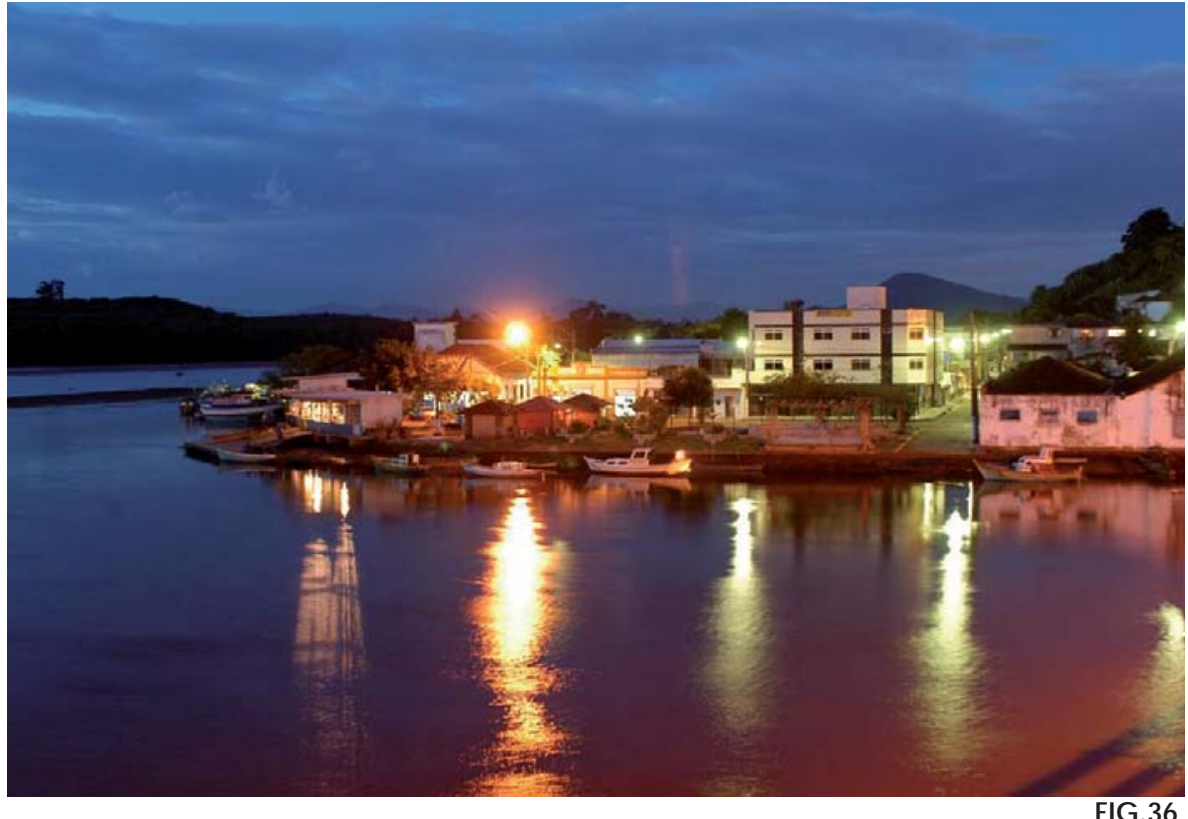

PG.36

A ideia de valor, portanto, não se atém apenas às pequenas escalas de objetos, mas se amplia para uma dimensão maior, a do sítio, o da cidade. Essa compreensão permite trabalhar a preservação de um território ou cidade, de forma ampliada, abordando-a como uma sucessão de substratos, de acúmulo de valores que se sobrepõem. Já se vincula também ao conceito de patrimônio, não necessariamente fatos memoráveis da história ou objetos que apresentem excepcional valor artístico. São exemplos dessas expressões marcos de identidade das minorias, marginalizadas, como os índios, negros e imigrantes (SOMEKH, 2001, p.116).

Considerando os novos valores sociais que se incorporam gradativamente ao conceito de patrimônio cultural, é importante rever não só os objetos oficialmente reconhecidos pela consolidação do ato jurídico (proteção legal), mas todo um conjunto de estruturas que está indissociavelmente ligado ao contexto histórico de Anchieta. Sob essa ótica, um novo olhar se impõe sobre o seu sítio e ambiências, fazendo crer que há, naquela simplicidade de seus arranjos urbanos, algo que se entrelaça com os seus atributos naturais, revelador de uma composição paisagística excepcional e intrínseca à população que ali habita. Impõe-se, não um olhar no sentido restrito da preservação, mas um olhar que reconheça o equilíbrio de uma ambiência que não pode se deixar desestruturar repentinamente mediante fenômenos que se estabelecem pelo viés dos poderes estritamente eco- 

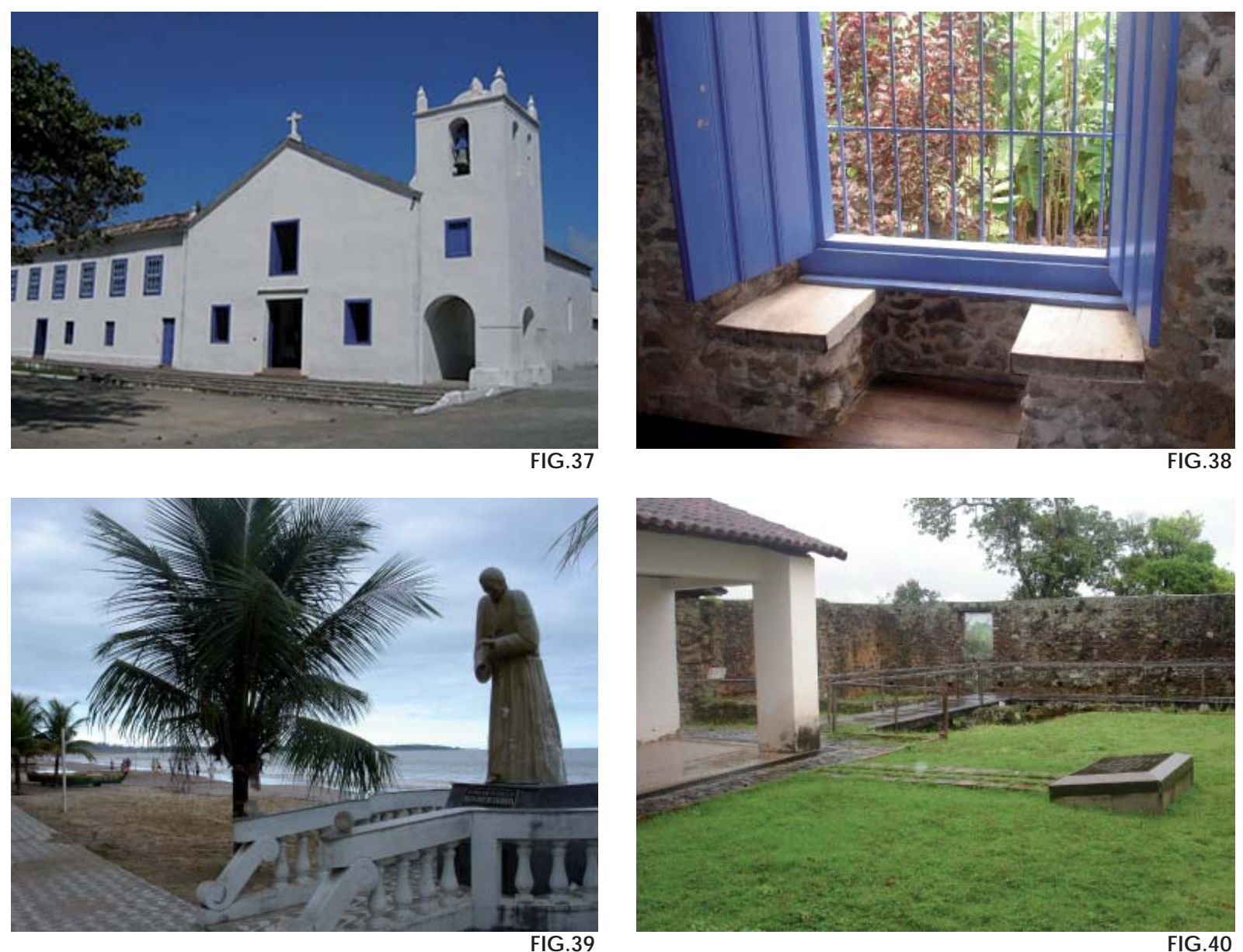

nômicos. O transcurso do tempo, embora traga o desgaste da obra humana, não foi capaz de apagar seu poder evocativo de uma ação histórica original: a presença jesuítica no solo espírito-santense nos primórdios da civilização brasileira.

Entre os objetos localmente qualificados no município de Anchieta, o Santuário Nacional de Anchieta ${ }^{94}$ é um dos mais significativos, impressos na paisagem de Anchieta, que faz referência ao período histórico da permanência dos jesuítas. Os historiadores não têm uma data precisa quanto à sua construção, mas estima-se que ela se iniciou com a formação da aldeia jesuítica, cujo término teria ocorrido apenas no começo do séc. XVII. O Santuário é composto pela Igreja de Nossa Senhora da Assunção mais residência anexa e Praça da Matriz. A construção do Santuário situa-se do lado norte da foz do rio Benevente, e sua fachada principal, tanto da

94 A sua construção foi iniciada em 1561 e, após a expulsão dos jesuítas, serviu como sede administrativa, hospedaria de viajantes, tribunal do júri, Casa de Câmara e Cadeia pública. Atualmente, abriga o museu do Beato Anchieta.

FG.37

Santuário de Anchieta com Igreja e residência anexa. Fonte: Acervo pessoal.

FG.38

Cela do aposento do Beato Anchieta. Fonte: Acervo pessoal

\section{AG 39}

Busto do beato Anchieta com a praia ao fundo. Fonte: Acervo pessoal.

Sítio arqueológico de Rinitiba onde foram encontradas populações indígenas. Fonte: Acervo pessoal. 
igreja quanto da residência, está voltada para o mar. O conjunto Igreja e residência foram tombados pelo Instituto do Patrimônio Histórico e Artístico Nacional (IPHAN), em 1943. No Espírito Santo, constata-se a existência de apenas duas residências fixas, nos princípios do século XVII: a de Riritiba, ao sul de Vitória, e a dos Reis Magos, ao norte.

Existem ainda os sítios arqueológicos da região, e os mais importantes, explorados até agora, localizam-se exatamente no Santuário de Anchie$\mathrm{ta}^{95}$. Esses sítios arqueológicos se referem aos diferentes grupos humanos que habitaram o espaço físico diretamente relacionado ao Santuário. O programa de restauração do Santuário, empreendido sob a coordenação do IPHAN entre 1994 e 1997, realizou uma pesquisa arqueológica e identificou, no local, basicamente dois sítios arqueológicos distintos, com vestígios independentes, mas complementares, e que se relacionam diretamente:

- O sítio arqueológico Igreja de Nossa Senhora da Assunção, que se refere ao local ocupado pelo conjunto arquitetônico do santuário e que pertence ao período histórico marcado pela presença religiosa.

- O sítio arqueológico de Riritiba, que se refere ao topo do morro onde está localizado o Santuário, e que foi inicialmente ocupado por populações indígenas ${ }^{96}$.

O sítio arqueológico de Riritiba, até 1997, ainda não tinha sido pesquisado, e dele pouco se conhecia. Mesmo assim, sabe-se que possui vestígios da ocupação humana de dois períodos: o pré-histórico e o período de ocupação dos indígenas que ali viviam na época da colonização européia (Agenda 21 Anchieta, 2006). É um sítio de grandes dimensões e, em determinado local possui quatro metros de profundidade, o que leva a crer que a população que ali vivia era bem numerosa e se fixou por longo tempo,

95 A sucessão de pequenas e grandes reformas que a obra sofreu ao longo do século XIX, atesta o seu estado precário, mas, ao mesmo tempo, revela que não houve descaso sistemático com ela por parte das autoridades provinciais, que se preocuparam sempre em preservar de alguma forma este patrimônio, evitando sua ruína total. Em 1994, teve início a última grande reforma do conjunto, feita pelo IPHAN, o qual ganharia grande visibilidade em virtude das comemorações do Quarto Centenário da Morte do Beato José de Anchieta, ocorridas em 1997, quando a obra foi inaugurada ( PREFEITURA MUNICIPAL DE ANCHIETA. Agenda 21 2006).

96 PREFEITURA MUNICIPAL DE ANCHIETA. Agenda 21 de Anchieta. Anchieta, 2006 


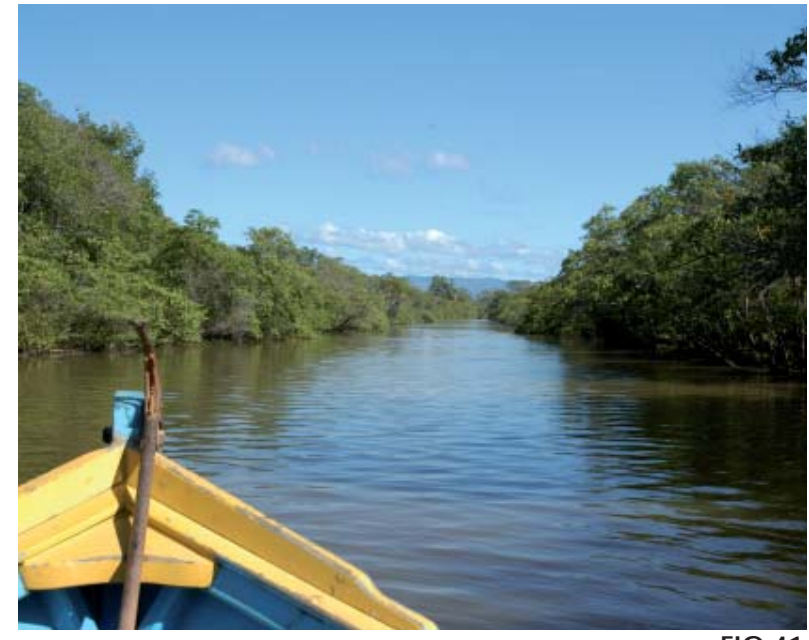

FG.41

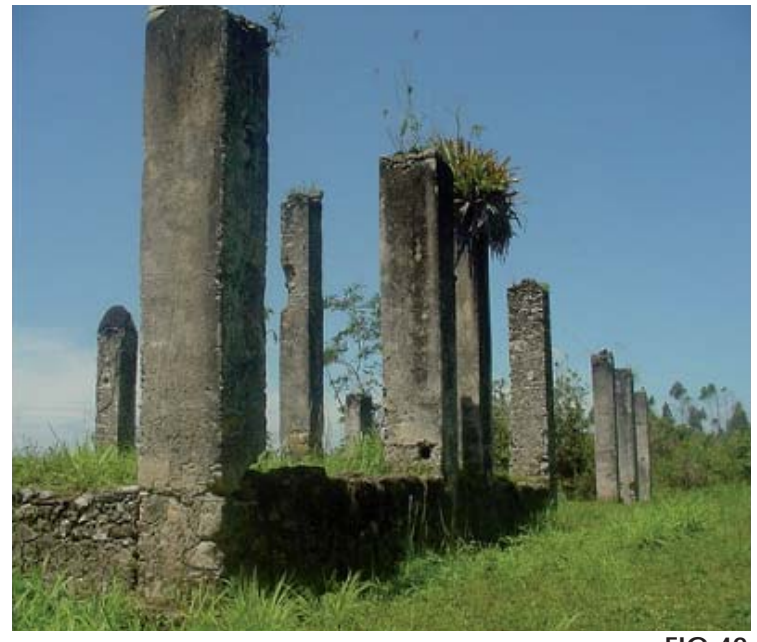

FG.42

RG.41

O Rio Salinas, tributánio do Rio Benevente que leva às Ruínas. Fonte: Acervo pessoal

HG.42

Ruínas do Rio Salinas, composta por 32 colunas e de origem ainda desconhecida. Fonte: Acervo pessoal

Poderíamos também citar outras construções representativas de uma época, tais como Capela de Nossa Senhora da Penha (1873), imóvel em processo de tombamento pelo Conselho Estadual de Cultura. O imóvel situado no morro do mesmo nome, a cerca de 100 metros da matriz de Nossa Senhora da Assunção. Sua arquitetura simples e lúcida tem como ponto marcante adornos em arcos de ogivas nas portas. Outro imóvel, representativo da imigração italiana, é o Casarão de Quarentena da Imigração Italiana (1870), também em processo de tombamento pelo Conselho Estadual de Cultura. O imóvel, de propriedade particular, fazia parte da antiga fazenda de São Martinho, e por ele passaram milhares de imigrantes que, da vila de Benevente partiram para colonizar todo o sul do estado. O Poço de Coimbra e Quitiba, Mercado Antigo, Armazéns do Porto são construções de menor significado histórico e arquitetônico, mas sempre 
referenciadas nos documentos oficiais (Agenda 21) como símbolos representativos na cidade de Anchieta.

As Ruínas do Rio Salinas (Anchieta), às margens do rio, são formadas por um aglomerado de 32 colunas de pedra, sendo as laterais mais baixas e as centrais mais altas. Tal arranjo das colunas induz ao formato de uma construção retangular e de grande porte. A origem e a história das ruínas ainda são um mistério, e várias são as especulações em torno das razões que motivaram sua construção, nenhuma comprovada cientificamente. Há diversas histórias que são contadas e recriadas pelos moradores locais aos visitantes. A primeira suposição é de que tenha sido uma igreja em função da disposição das colunas laterais formando naves; a segunda hipótese é de que tenha sido um armazém clandestino de sal e/ou ouro para evitar embarque para a Coroa portuguesa; a terceira é a de que talvez tenha sido um casarão de engenho, e que famílias que ali habitavam tenham sido expulsas pelos indígenas que dominavam a região. As ruínas são, hoje, um dos maiores atrativos turísticos do município, e as estórias contadas pelos guias criam um ar de mistério e um diferencial a mais na rota turística.

As cidades de Anchieta e Piúma acrescentam à vocação turística as manifestações culturais que lhes são inerentes e que reafirmam as tradições locais. O bucolismo do lugar ainda está resguardado, de certa forma associado às redes e barcos da pesca artesanal e ao artesanato de conchas. $\mathrm{O}$ arranjo produtivo relacionado ao artesanato de conchas abriga um grande número da população. Organizado pelas catadeiras de conchas, movimenta oficinas de confecção de artigos, tais como, adornos e objetos de decoração, lojas de artesanato e vendedores ambulantes nas praias. As conchas encontradas na natureza (mar e praias) podem ficar ameaçadas com as mudanças de maré ou outros impactos provenientes da exploração de petróleo no alto mar. A pesca também já está sendo diretamente afetada pela presença das plataformas de petróleo, que eliminam dejetos e concentram os peixes em torno delas.

Entre outras manifestações culturais das mais expressivas, estão também as bandas de congo. A caminhada denominada "Passos de Anchieta" é a mais recente manifestação cultural do município e ocorre todo ano, desde 1998. O percurso, que sai de Vitória e vai até a cidade de Anchieta, é o 
mesmo que o beato José de Anchieta realizava.

\subsubsection{Ecossistemas e ambiente urbano}

As relações dos homens na apropriação e uso dos elementos da natureza são relações constitutivas do ambiente urbano. Natureza e cidade remetem, antes de qualquer coisa, a um campo coletivo, ainda que apropriado pelos diversos agentes. Por isso mesmo, um campo de tensões, que têm a ver com a existência das suas possibilidades de realização, com as oportunidades e com as práticas. Trata-se, aqui, de uma preocupação pertinente, uma vez que hoje se constata, no país, a existência quase generalizada de conflitos dessa natureza. Entende-se por impacto ambiental qualquer alteração produzida pelos homens e suas atividades, nas relações constitutivas, que excedam a capacidade de absorção do ambiente natural. A atividade industrial é uma das formas de ocupação espacial que traz maiores repercussões sobre o ambiente; daí a importância de contextualizar os ecossistemas representativos da configuração do território e relativizá-los quanto às pressões exercidas pelas ações externas.

A abordagem dos ecossistemas como propiciadores de recursos (atuais ou potenciais) para uso humano é uma ótica que abarca as proposições nas quais se programam alterações. É fundamental, portanto, conhecer as estruturas ecossistêmicas que qualificam o cotidiano coletivo e a paisagem da microrregião região sul, detendo-se mais especificamente na abordagem do município de Anchieta. Em geral, as mudanças introduzidas pelas atividades humanas num determinado território levam a reações dos ecossistemas, que uma vez alterados, fazem funcionar os mecanismos que os regulam. Porém, ao se excederem as possibilidades limites desses mecanismos, sucede a ruptura do equilíbrio ecológico. É evidente que o conhecimento dos ecossistemas e da forma como eles se comportam no ambiente urbano, por si só, não basta para explicar as eventuais novas configurações diante das ações impactantes. As transformações se dão por formas visíveis no espaço, criando paisagens que assumem significado quando compreendidas as interrelações mais abrangentes.

Além dos símbolos que integram o patrimônio histórico, artístico e cultural, atribuindo valores e significados à região, não há como deixar de 
mencionar os valores ambientais, como os rios, mangues, enseadas, que constituem a beleza natural da paisagem. Os ecossistemas ${ }^{97}$ compõem entidades particulares, cujos padrões sofrem alterações pela ação humana, mas são presentes, ainda hoje em fragmentos com diferentes graus de continuidade, no território de Anchieta. Alguns autores definem os elementos componentes do ecossistema - os elementos vivos (organismos) e os não vivos (meio físico) em interações -, definem a natureza destas interações - fluxos de energia e informação entre organismos e meio físico; e definem a finalidade destas interações - a nutrição e a biodiversidade.

Nos ecossistemas que abrangem aglomerações de população e atividades humanas, a energia e as matérias necessárias a seu desenvolvimento provêm predominantemente, do seu exterior. Isto possibilita o desenvolvimento destes ecossistemas tendo por limite apenas a disponibilidade de recursos naturais não importáveis. Vem daí o interesse, nos ecossistemas urbanos, pela preservação do ar, da água, do solo e do microclima, cujo esgotamento pode impor limites a seu desenvolvimento. Assim, elementos do solo, da água e do ar são importantes condicionantes do meio físico que irão permear e absorver, de certa forma, os impactos avindos das ações humanas, procurando manter a integridade das forças que interagem no ambiente urbano. Esses pressupostos possibilitam identificar as relações constitutivas do ambiente urbano. Se houver alterações significativas nessas relações que excedam a capacidade de absorção do ambiente considerado, temos, então, o impacto ambiental.

Particularmente na definição de políticas públicas, o meio urbano mobiliza uma rede de interesses presentes tanto no aparelho estatal quanto nas organizações empresariais, criando uma permeabilidade entre a formulação e implementação das políticas públicas e os interesses desses setores no capital, o que gera conflitos que recairão fundamentalmente no uso do solo. Os ecossistemas são aqueles que, irremediavelmente, sofrem as consequências das ações geradas pelos agentes intervenientes do espaço,

97 Para biólogos, o ambiente que inclui organismo em interação com o meio físico é o ecossistema, um "sistema resultante da integração de todos os fatores vivos e não vivos do ambiente" (TASLEY apud Branco; Rocha, 1987, p.20), ou seja “[...]qualquer unidade que inclua todos os organismos (a 'comunidade') de uma determinada área interagindo com o meio físico de forma tal a originar um fluxo de energia definindo claramente uma estrutura trófica, uma diversidade biológica e um ciclo de matérias (intercâmbio de matéria entre partes vivas e não vivas)" (ODUM, apud Branco e Rocha 1987, p.20). 


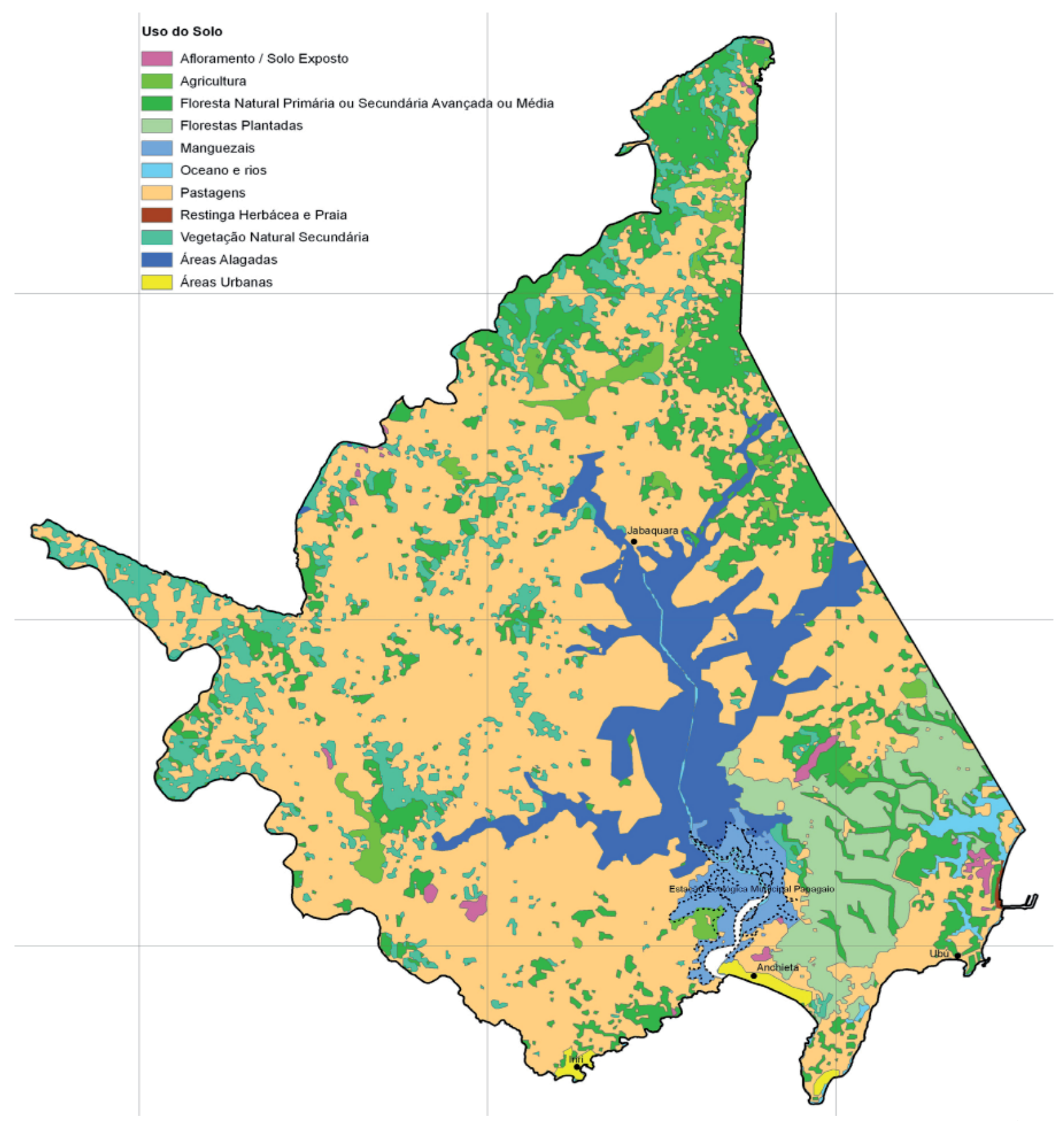

RG.43

especialmente quando fundadas na concentração de tecnologias. Feitas essas considerações acerca de ambiente e do ecossistema, procede-se à apresentação dos ecossistemas representativos do município de Anchieta e do entorno imediato, para verificar, no próximo capítulo, como estas relações se cristalizam mediante processos de urbanização.

\section{- A forte presença do componente "água" em Anchieta}

A presença da água num determinado território pressupõe também a pre- 
FG.43

Mapa Uso do Solo do município Anchieta. A rede hídrica é bastante expressiva em nios e lagoas. Fonte: IJ SN - Perfil Municipal sença do homem. Daí a relevância da rede hídrica e a importância de como o fluxo das águas deve ser compreendido e tratado em áreas de assentamentos humanos. Pode-se afirmar que, no contexto da evolução histórica das vilas, povoados até se chegar às grandes cidades, o caminho das águas determinou, de certa forma, o caminho dos homens, o que denota uma perspectiva de interação homem e natureza, possibilidades e variações combinadas que criam raízes e identidades incorporadas no espaço da vida cotidiana.

Os principais rios que cortam o município de Anchieta são o Joeba, o Corindiba, o Pongal e o Benevente. Este último tem especial importância histórica, cultural e de abastecimento de água para o município. Com a imigração italiana, o rio Benevente foi bastante utilizado como via navegável para acesso às terras férteis da região serrana de Alfredo Chaves, no último quartel do século XIX, difundindo a cultura cafeeira em pequenas propriedades. E o porto, que serviu de entrada para os imigrantes, tornouse saída para a exportação de café de toda essa próspera região. No caso dos recursos hídricos, há um claro desequilíbrio entre a velocidade de crescimento populacional e de atividades urbanas, gerando novas demandas por água potável, e a ofertas desses recursos.

A baía que circunda a foz do rio Benevente é de extrema beleza paisagística. A vegetação de mangue surge a partir do estuário do rio e avança pelas suas margens em direção ao continente por uma extensão de $6,5 \mathrm{~km}$. O manguezal ocupa também as bordas do Córrego Arerá, do rio Salinas e outras ilhas menores, próximas à embocadura do rio Salinas. O importante ecossistema manguezal forma bosques de poucas espécies de árvores, mas que tem um papel fundamental como fonte de alimentos para a fauna marinha associado ao baixo curso do rio Benevente e de seus afluentes nessa sua porção.

Ocupando uma área de aproximadamente $7.772 \mathrm{Km} 2$ de área de bosque, o manguezal do rio Benevente representa para a população de Anchieta um patrimônio inestimável, devido à sua posição biogeográfica, servindo de berço às primeiras formas de vida aquática, que aí encontram alimento em abundância. Nos bosques de mangues de Anchieta, ocorrem a Rhizophora mangle (mangue vermelho), a Laguncularia racemosa (mangue branco) 


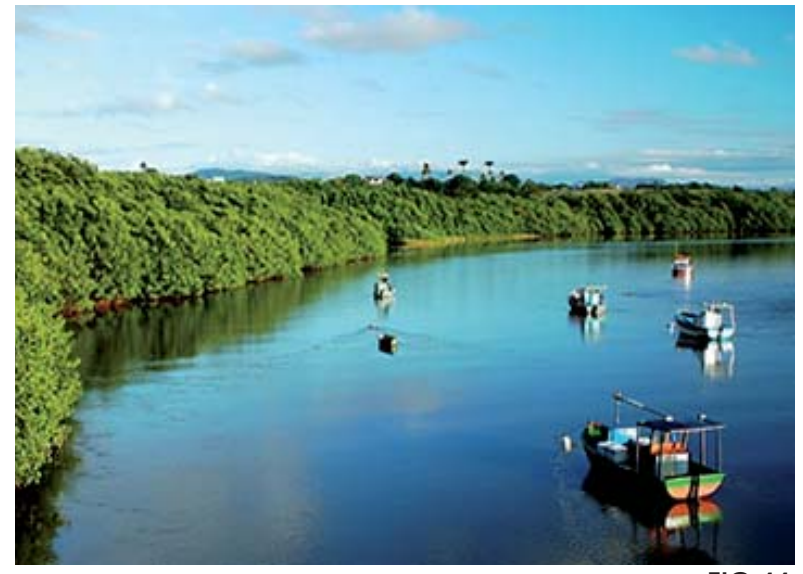

FG.44

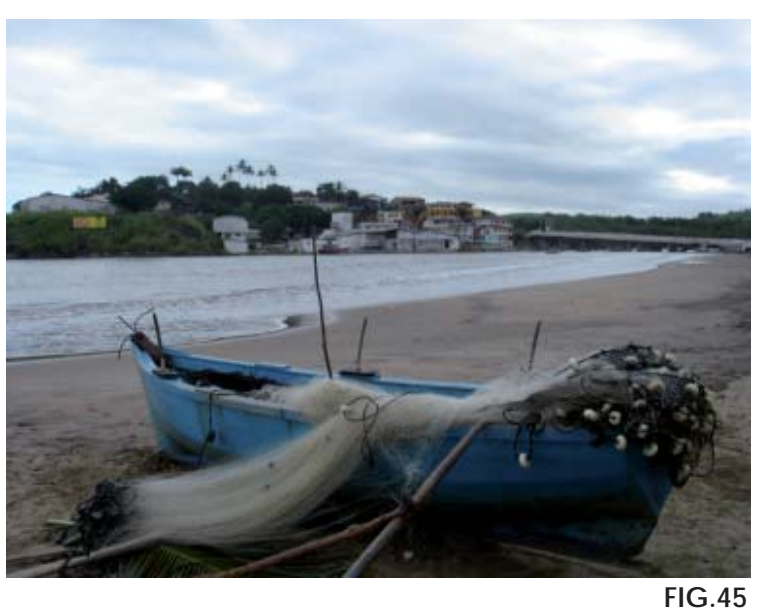

RG.45 e a Avicennia Schaweriana (mangue negro) ${ }^{98}$. Embora parcialmente sob proteção da prefeitura municipal, ainda se observam alguns impactos do manguezal de Anchieta, provocados principalmente por desmatamentos clandestinos e pela presença de esgotos e agrotóxicos, derramados no rio Benevente e tributários, seja pela população de Anchieta, seja pela população dos municípios situados a montante de sua bacia. O manguezal tem sua expressão mais representativa na Estação Ecológica Municipal Papagaio, uma ilha situada ás margens do Rio Benevente. A preservação dos manguezais do rio Benevente é de fundamental importância, para reduzir os impactos no modo de vida da comunidade, que tem na atividade pesqueira principal fonte de renda. Nesse contexto ambiental, realiza-se uma das rotas turísticas das mais aprazíveis: é aquela que se faz de barco subindo o Rio Benevente até encontrar o Rio Salinas. O circuito de barco passa pela Estação Ecológica do Papagaio, uma ilha de proteção integral (regulamentada pelo $\mathrm{SNUC}^{99}$ ), inserida em meio a uma extensa área de manguezal com formação arbustiva que acompanha o percurso inicial do Rio Benevente.

Outra formação paisagística constante no município de Anchieta são as lagoas. $\mathrm{O}$ aspecto cênico expresso pelas lagoas de Anchieta faz com que elas sejam consideradas importantes no contexto dos bens patrimoniais

\section{RG.44}

A foz do Rio Benevente forma uma baía de excepcional beleza junto ao manguezal. Fonte: Aceno pessoal

\section{FG.45}

O barco, a rede e a pesca, símbolos da tradição local. Fonte: Acervo pessoal 

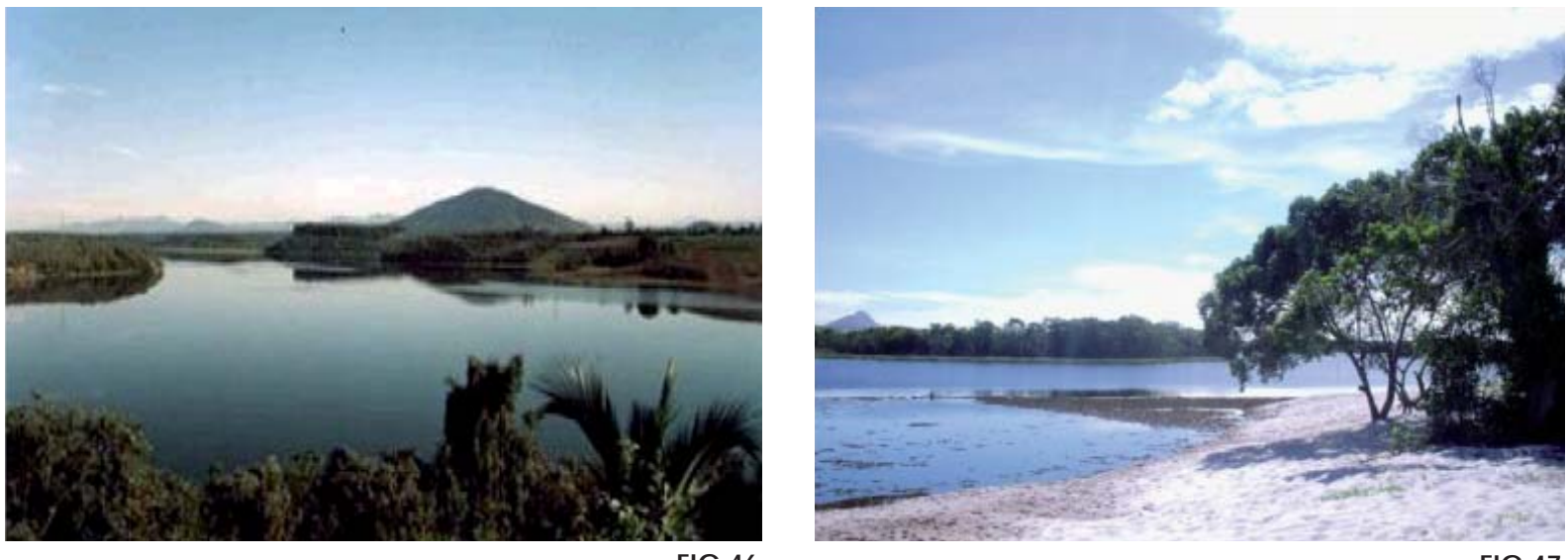

HG.46

FG.47

FG.46

Lagoa Mãe-Bá. Fonte: Acervo pessoal

FG.47

APA de Guanandy. Fonte: $\varangle$ www.meioambiente. com.br naturais a serem garantidos. Essas lagoas são ambientes particularmente suscetíveis à poluição, seja orgânica, causada por despejos residenciais e consequente proliferação de organismos aeróbicos com mortandade de peixes, seja por despejos de efluentes industriais ou pelo uso indiscriminado de agrotóxicos nas lavouras da sua bacia de contribuição. Vale ressaltar que a maior lagoa de Anchieta é a Mãe-Bá100 , em cujas imediações está situado o Polo Industrial. Em relato feito por moradores, a lagoa de Tanharu, situada na praia de Castelhanos, e a lagoa de Mãe-Bá são dois exemplos de exposição à poluição por diferentes causas. A primeira, por dejetos e efluentes domésticos associados à ocupação residencial em seu redor; a segunda, derivada dessa razão e associada à presença da indústria SAMARCO, a qual represa um dos braços desse corpo hídrico para constituir a sua lagoa de tratamento de efluentes. A poluição causada por materiais carreados pelas chuvas, quando a erosão age sobre os solos descobertos, resulta no assoreamento das lagoas e cursos d'água, com posterior entupimento de bueiros e obras de drenagem pluvial. Por esses motivos, os projetos de esgoto sanitário e drenagem pluvial de loteamentos urbanos e instalações industriais, localizados nas bacias hidrográficas dessas lagoas, merecem estudos para que seja evitado qualquer tipo de poluição.

\section{- As formações de restingas, arrecifes, dunas e a presença de} parques naturais

A transição para as formações abertas das vegetações de restinga, a cha-

100 O nome "Mãe-Bá" é em homenagem à chefe da Tribo Negros-Galinhas (que habitavam a região). Essa índia, de nome Bá, era considerada mãe de todos. Em Tupi-Guarani, Mãe(essé)=Olhar, então Bá era "a que olhava por todos".Fonte: PREFEITURA MUNICIPAL DE ANCHIETA. Agenda 2,.2006 
mada Mata Seca, limita a ocorrência entre as encostas montanhosas e as baixadas. A restinga, de forte influência marinha, se divide em ocorrências sob a forma de vegetação rasteira, ao longo das praias que se estendem de Ubu até Iriri, em diferentes condições de preservação, sendo a principal ocorrência associada às praias de Parati e Guanabara. Essas formações vegetacionais, que, ao longo dos canais fluviais compõem as matas ciliares, quando próximo das áreas litorâneas, sob influências das marés, dão lugar à formação de manguezais de franja (RADAMBRASIL, 1983).

A fixação de construções arenosas responde pela preservação das formas de cordões e pequenas dunas litorâneas situadas na baixadas praianas, que vêm sendo alvo do impacto causado pela edificação na orla do município. A sua estreita ocorrência, associada à berma praial ${ }^{101}$ entre a zona intramaré e as encostas de falésias, coincide com local de adensamento das edificações de veraneio e as ocupações tradicionais do centro de urbano de Anchieta. Essas áreas possuem uma condição instável de manutenção por se encontrarem constituídas por material de baixa coesão e sob influência da ação das marés. Tais condições já se revelam problemáticas em áreas similares de municípios próximos como Piúma e Marataízes, cidades que apresentam forte impacto condicionado pela ação erosiva do mar nas áreas de ocorrência de terraços (berma praial). Ao sul da foz do rio Benevente até Iriri, a vegetação é composta de espécies arbustivas de pós-praia.

A formação de restinga também se estende pelos bordos das lagoas locais formando uma linha marginal aos corpos hídricos, que se apresenta como vegetação herbácea brejosa, e com aspectos de vegetação aquática (aguapés) junto às posições de remanso, contribuindo para inibir o transporte sedimentar para o interior desses corpos aquáticos. Alguns desses brejos se acham comprometidos pela drenagem promovida por silvicultura de eucalipto e por pastagens, como os localizados próximos à localidade de Belo Horizonte, identificados pela ocorrência de solos arenosos em depressões fechadas, na qual a vegetação exótica pouco se desenvolve. Tais brejos constituem, na sua origem, depressões funcionais do sistema de

101 Berma praial é a zona da praia quase horizontal, constituída pela deposição de sedimentos pelas ondas, e que, em geral, apresenta suave pendor em direção ao continente, e pendor mais abrupto em direção ao mar. Os bermas praiais correspondem a acidentes fisiográficos não permanentes, sendo normalmente destruídas / construídas durante ou após temporais. Algumas praias não têm bermas, enquanto que outras apresentam duas ou mais bermas. Fonte: ESPAÇO CONSTRUTORA. Estudos para formulação do Plano Diretor Municipal de Anchieta. 2006 


\section{PARQUES PROPOSTOS E AREAS DE INTERESSE AMBIENTAL}

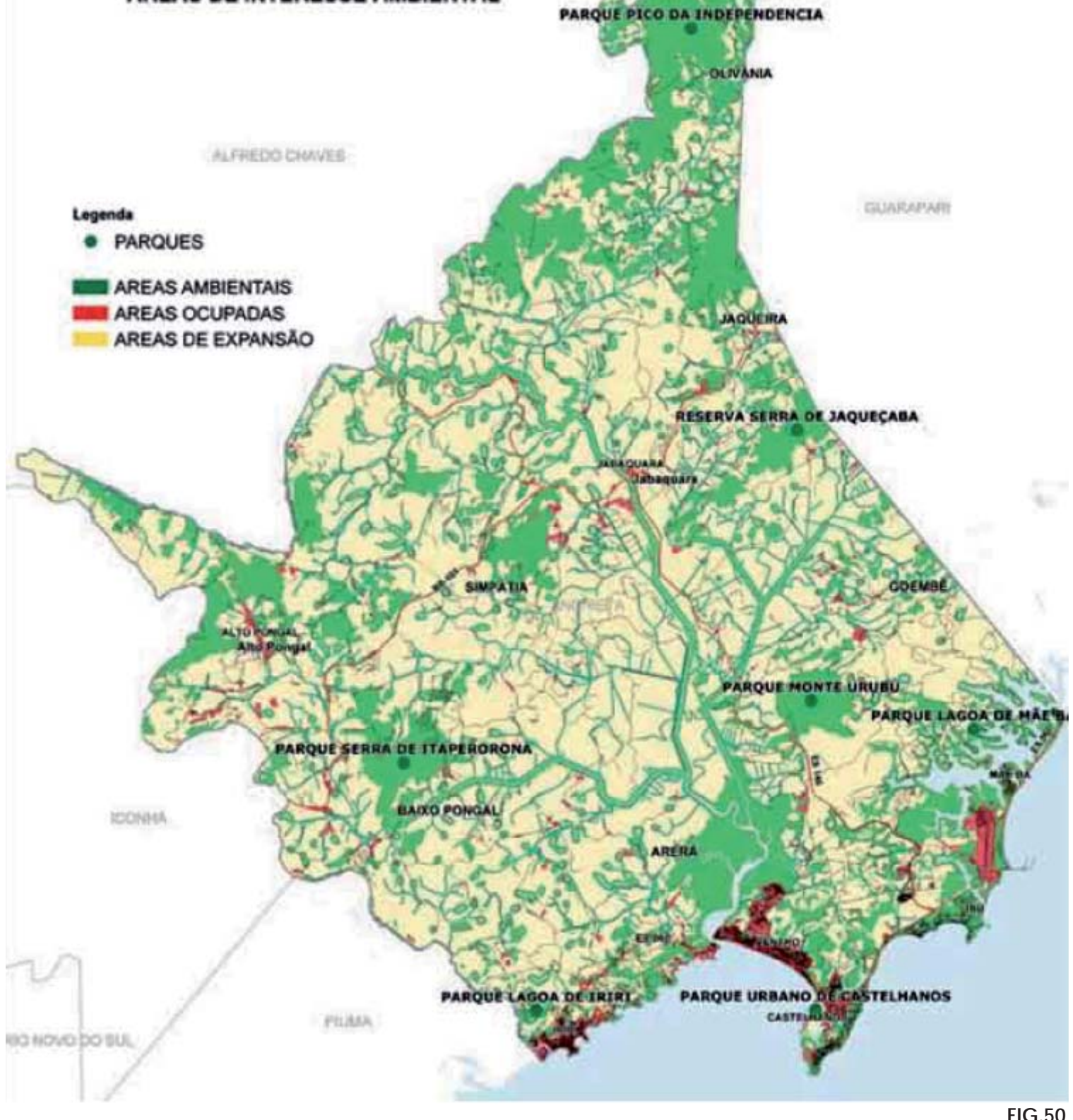

RG.50

A criação de parques sugeridos pela Agenda 21 de Anchieta. Fonte: Prefeitura Municipal de Anchieta. Agenda 21. recarga de aquíferos subsuperfíciais, alguns dos quais abastecedores de nascentes e cabeceiras de drenagens fluviais associadas aos sistemas de contribuição das lagoas locais e dos canais tributários do baixo curso do rio Benevente. No alto dos tabuleiros situados ao norte do rio Benevente, percebe-se a transição da mata de restinga para mata de encosta. Esse conjunto é o mais afetado pelas atividades humanas, especialmente, pastagens e silvicultura, não restando mais do que fragmentos esparsos que atestem a transição vegetacional entre o ambiente costeiro e o continental ${ }^{102}$.

102 PREFEITURA MUNICIPAL DE ANCHIETA. Agenda 21. 2006 


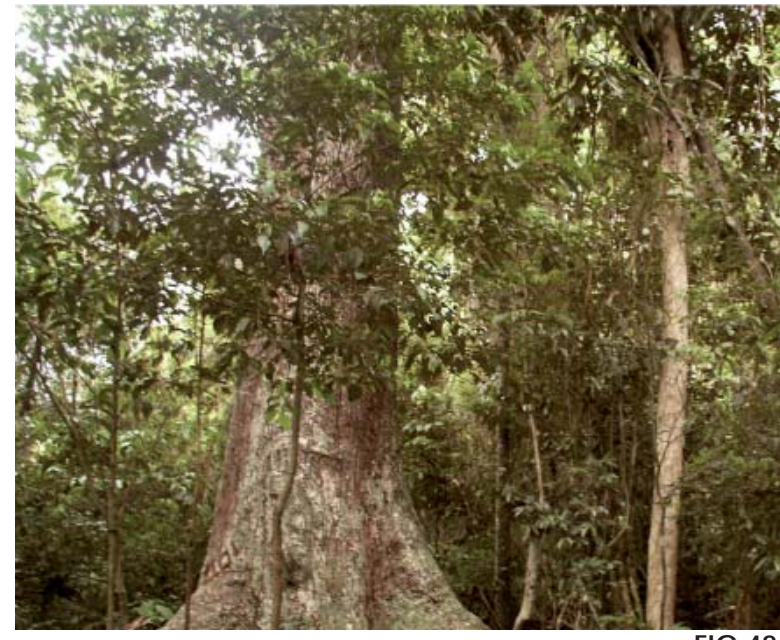

RG.48

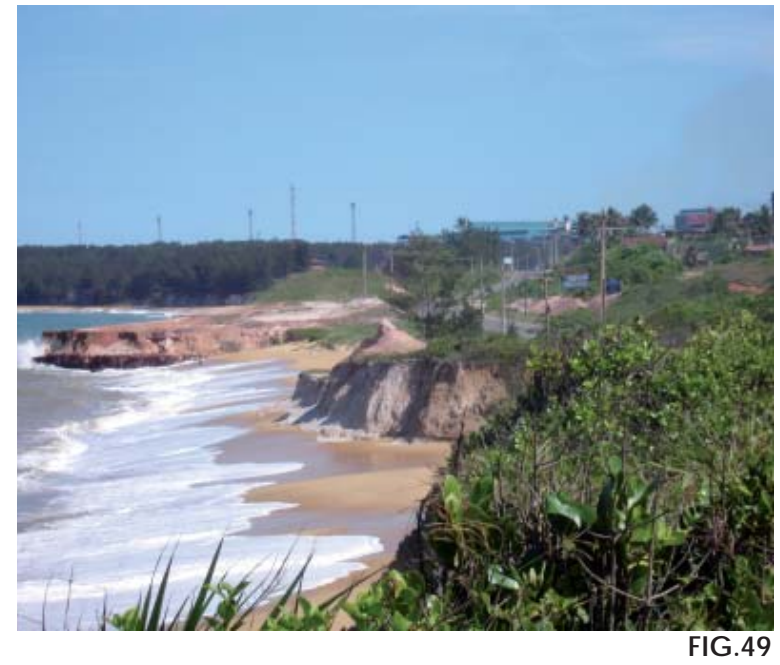

RG.48

Floresta de transição entre o mangue e a Mata Atlântica. Fonte: Acervo pessoal

FG.49

Falésias em Ubu. Fonte:

Acervo pessoal

O município de Anchieta é também rico em parques naturais. Embora a cobertura vegetal de Anchieta esteja numa situação crítica, o município ainda é reconhecido em virtude das áreas verdes constituídas pelos remanescentes naturais. Entre esses parques naturais, podemos destacar: Parque Pico da Independência e Reserva Serra de Jaqueçaba (a noroeste do município, quase divisa com Guarapari); Parque Lagoa de Mãe-bá; Parque Monte Urubu (ao centro do Município); Parque de Itaperorona; Parque Lagoa Iriri; Parque Urbano Castelhanos.

\section{- Unidades de Conservação}

As Unidades de Conservação são áreas com características naturais relevantes, legalmente instituídas pelo poder público para a proteção da natureza, com objetivos e limites definidos. Elas podem ser criadas pelos governos federal, estadual ou municipal. Segundo a lei 6.938, de 1981, as 
Tabela16

Pontos fortes e elementos de destaque do município de Anchieta em relação ao meio ambiente

\begin{tabular}{|c|c|}
\hline Pontos Fortes & Elementos de destaque \\
\hline $\begin{array}{l}\text { )iversidade de ecossistemas possibilitando } \\
\text { natriz de desenvolvimento }\end{array}$ & Ec ossistemas ma rinhos, terrestres e estua rinos. \\
\hline sisponibilida de hídrica & $\begin{array}{l}\text { Auto-suficiência para atendimento de demandas atual e futura, } \\
\text { com aproveitamento racional de seuscorpos d'água superficiais. }\end{array}$ \\
\hline :omplexo lagunar com potencial tuństico & Lagoas de Mãe-Bá, Castelhanos, Ubú, Tanharu e Iniń. \\
\hline itoral balneável & $23 \mathrm{~km}$ de praiasbalneáveis \\
\hline
\end{tabular}
Fonte: PREFEITURA MUNIC PAL DE ANCHIETA. Agenda 21

UC's são um dos instrumentos da Política Nacional do Meio Ambiente. As áreas de Proteção Ambiental (APAs) ${ }^{103}$ são áreas submetidas ao planejamento e à gestão ambiental, regulamentadas pelo SNUC. ${ }^{104}$ A proteção legal destina-se à compatibilizar atividades humanas com a preservação da vida silvestre, a proteção dos recursos naturais e a melhoria da qualidade de vida da população local.

As APAs podem compreender uma ampla gama de paisagens naturais, seminaturais ou alteradas, com características bióticas, abióticas, estéticas ou culturais notáveis, que exijam proteção para assegurar as condições ecológicas locais. Podem conter ecossistemas urbanos ou outras Unidades de Conservação mais restritivas em termos de utilização e permitem a experimentação de novas técnicas e atitudes que possibilitem conciliar o uso da terra e o desenvolvimento regional com a manutenção dos processos

103 Com as APAs, surge a proposta de defesa da natureza, e elas que podem ser declaradas tanto em área pública como em propriedades privadas. Nelas, as atividades econômicas são permitidas dentro de limites determinados pelo órgão responsável por sua gestão, possibilitando a atuação na proteção da natureza. São muitas as áreas, importantíssimas sob o aspecto ambiental, que precisam ser desapropriadas e integralmente protegidas. Assim, as APAs, que prescindem de desapropriação, não propriamente resolvem a questão, mas dão abertura a uma forma alternativa e complementar de proteção da natureza, servindo para serem usadas em diversas situações de grande importância. Por exemplo, como zona tampão de um parque ou de uma reserva biológica. Servem, também, para uma área que, por estar em fase de estudos, não tem definição quanto a ser mais apropriado declará-la como Estação Ecológica ou outra categoria de unidade de conservação. Nesse sentido, as APAs funcionam como uma primeira proteção, até que se tenha maior informação sobre o zoneamento necessário e o grau de proteção que se deve aplicar.

104 O Sistema Nacional de Unidades de Conservação, criado por meio da Lei no 9985/2000, estabelece dois grandes grupos de categorias de unidades de conservação, com características específicas: o grupo de unidades de Proteção Integral e o grupo de Uso Sustentável. O grupo das Unidades de Proteção Integral é composto pelas seguintes categorias de unidade de conservação: Estação Ecológica; Reserva Biológica; Parque Nacional; Monumento Natural; Refúgio de Vida Silvestre. 
ecológicos essenciais.

Entre as diferentes maneiras de se assegurar a proteção dos recursos naturais, as unidades de conservação representam um mecanismo que permite:

a) a conservação in situ de partes significativas dos ecossistemas naturais, preservando a diversidade genética;

b) a efetivação de uma rede de áreas protegidas, orientadas pelo SNUC, que possam interagir para garantir o processo evolutivo;

c) a garantia do processo de autoregulação dos ecossistemas;

d) a participação da comunidade nas ações de conservação.

Entre as áreas representativas de ecossistemas nativos de Anchieta e protegidas pelo SNUC, temos a Estação Ecológica Ilha do Papagaio. As Estações Ecológicas destinam-se oficialmente à realização de pesquisas básicas e aplicadas, à proteção do ambiente natural e ao desenvolvimento da educação conservacionista. Segundo a conceituação, elas devem existir para cada um dos biomas do país, em área suficientemente ampla para permitir a preservação de sua biodiversidade. As Estações Ecológicas devem ter pelo menos 90\% de sua área destinada à preservação integral e, nos 10\% restantes, podem, mediante autorização e dentro de um zoneamento previamente estipulado, realizar pesquisas de interesse científico que acarretem modificações no ambiente natural.

A Estação Ecológica Ilha do Papagaio (Lei Municipal 17/92), uma ilha de manguezal com uma área de 457 ha, situa-se no alargamento do Rio Benevente. É o único lugar em Anchieta onde se encontram ninhos de papagaios verdes e vermelhos, além de garças. Apesar da riqueza do ecossistema e da singular beleza cênica, a Ilha do Papagaio tem seus limites sobrepondo e conflitando, em um pequeno trecho, com os limites do polígono do Polo Industrial e de Serviços de Anchieta. A Estação Ecológica ainda não apresenta Plano de Manejo.

A Área de Proteção Ambiental Praia da Guanabara, criada em 1998 pela Lei Municipal 008/98, protege o maior sítio de desova de tartaruga no município de Anchieta. A equipe da Secretaria Municipal de Pesca e Meio Ambiente, com atuação diária da Brigada de Educação Ambiental e com 
a participação das comunidades locais, vem realizando desde 1995, o programa "Proteção e o Monitoramento das Tartarugas Marinhas", os quais procuram o litoral de Anchieta, para alimentação e para completar o seu ciclo reprodutivo. Nos meses de outubro a fevereiro, as tartarugas desovam na areia da praia/restinga, e, que após o tempo de incubação de aproximadamente 60 dias, os filhotes eclodem.

De acordo com o Protocolo de Proteção às Tartarugas Marinhas, firmado entre a Prefeitura Municipal de Anchieta-ES e Centro TAMAR-IBAMA (Projeto TAMAR), é de responsabilidade da equipe técnica da prefeitura coordenar estagiários e agentes da Brigada Ambiental, nas atividades de presenciar, durante o período noturno, a postura dos ovos, para posterior verificação do estado de saúde, medição, identificação das fêmeas; efetuar, ao amanhecer, a localização e a identificação dos ninhos, o acompanhamento dos nascimentos; promover a educação ambiental, com palestras, informações e atendimento a veranistas, turistas, moradores, assim como a alunos e professores das escolas da região. As atividades de educação ambiental visam também orientar mudanças de hábitos e costumes da população quanto aos possíveis danos causados pelo tráfego de veículos nas praias e restingas, pelas práticas predatórias de captura e pela fauna e flora e pela iluminação inadequada, em desacordo com as legislações vigentes. Essas práticas urbanas são nocivas à reprodução das tartarugas e podem acarretar a mortandade de filhotes, com a desorientação no trajeto praia/ mar e o afugentamento das fêmeas adultas.

Outras unidades de conservação são o Pico da Independência e o Monte Urubu. O Pico da Independência é o ponto culminante de Anchieta, com $752 \mathrm{~m}$ de altura, e está localizado ao norte do município, fazendo divisa com o município de Alfredo Chaves. O Monte Urubu, com 332m de altura, é o testemunho isolado a leste do município, junto à margem esquerda dos rios Benevente e Salinas. Essa formação de relevo empresta à paisagem local um aspecto imponente, quando observada do rio Benevente, destacando-se sobre os manguezais.

Destaca-se, dentre outros referenciais naturais da paisagem, a APA de 


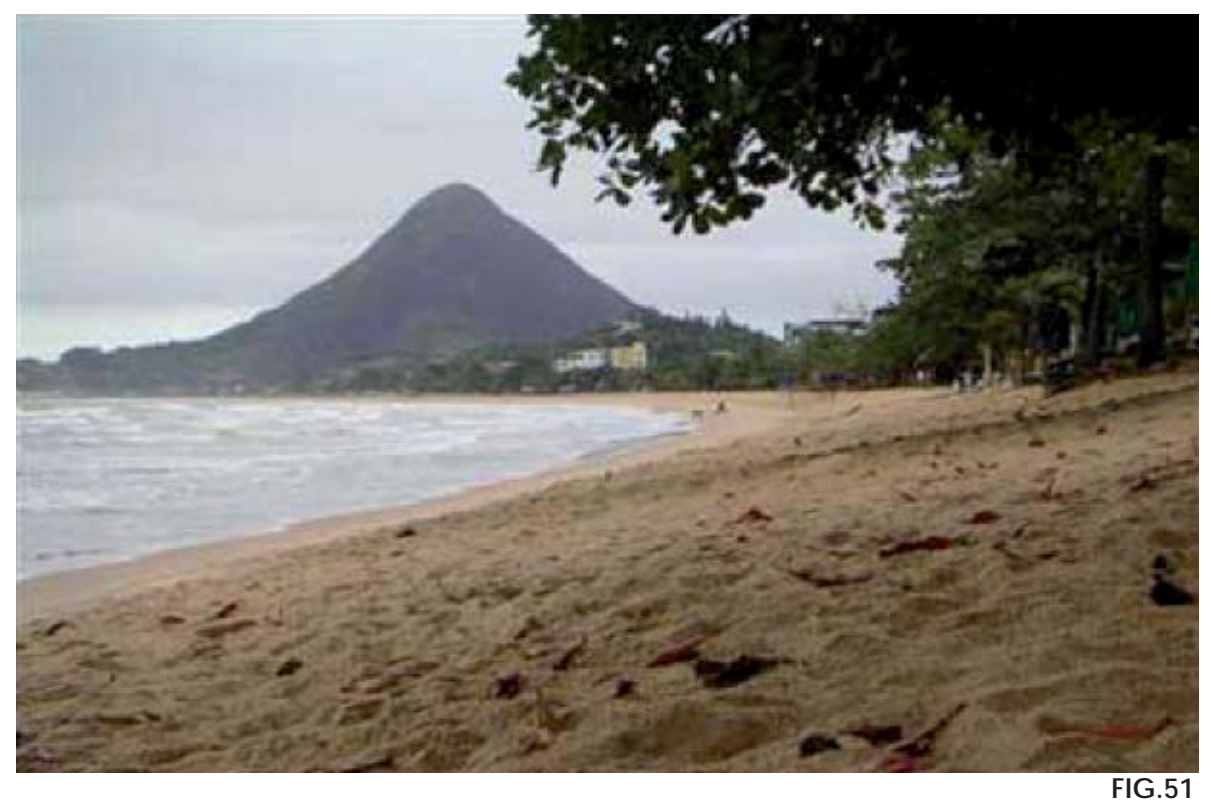

RG.51

Monte Aghá, em Píuma, é visto das praias de Anchieta. Fonte: Acervo pessoal

FG.52

Monte Aghá destacase na paisagem. Fonte: Acervo pessoal.

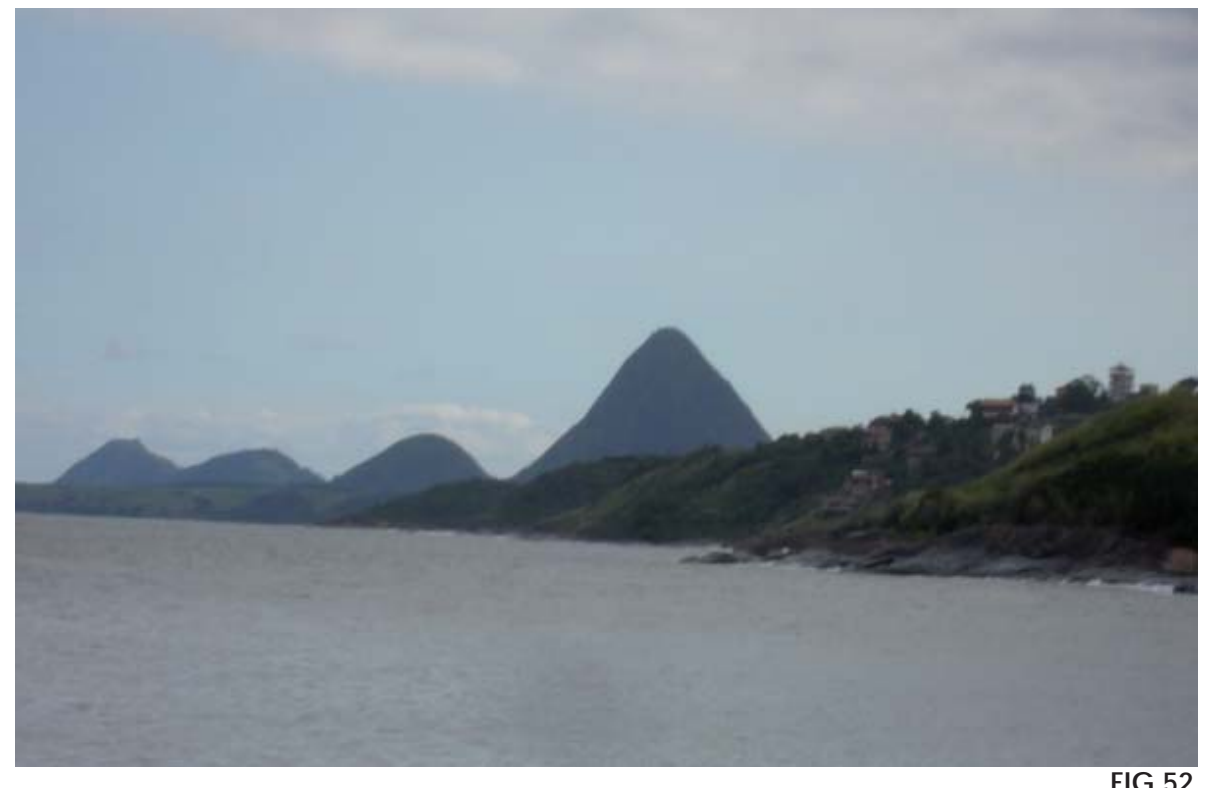

Guanandy, cuja área ${ }^{105}$ territorial engloba os municípios de Piúma, Itapemirim e Marataízes. Apesar de estar numa região vizinha ao município de Anchieta, é um referencial de destaque na paisagem, cuja vista se alcança de vários locais da região de entorno, em especial das praias de Anchieta e Piúma. Guanandy é uma das poucas Áreas de Proteção Ambiental exclusivamente costeira do litoral sul. A considerável beleza cênica dessa APA lhe confere um grande potencial ecoturístico. Por sua relevância biológica, é considerada prioritária para conservação e foi escolhida para compor a maior parte do Corredor Ecológico do Guanandy. A Lagoa do Guanandy

105 A APA de Guanandy perfaz um total de 5.242 há de área. 
também é um atrativo importante. Devido a seu formato sinuoso, é conhecida como Lagoa das Sete Pontas. O artesanato realizado pelas comunidades locais, principalmente pela Associação das Mulheres do Guanandy, as quais utilizam sementes para confeccionar colares e bolsas, também é outra peculiaridade da região.

Por fim, o Monte Aghá com 300m de altura, é um Bem Natural Tombado pela Resolução n ${ }^{\circ} 6$ de 1985 e considerado um marco referencial na paisagem da praia de Piúma. A sua forma piramidal é visível de vários pontos da microrregião sul, inclusive do próprio município de Anchieta. O seu nome tem significado indígena (Puris - Tupiniquins) e quer dizer "Monte de Ver Deus". O Monte está sujeito à degradação, uma vez que não existe nenhuma legislação complementar que vislumbre a forma de ocupação no entorno do bem natural. A vulnerabilidade se torna mais evidente pela ocupação urbana já existente nas proximidades e pela pressão da especulação imobiliária.

As áreas de relevantes belezas cênicas merecem, por suas virtudes, ser consideradas como patrimônio ambiental do município, e, com isso, passar a dispor da garantia de área protegida. Essa medida garante a conservação do patrimônio e possibilita à municipalidade gerar recursos por meio do turismo contemplativo, náutico, ou ecológico. 
232| CAṔ́tULO 6 


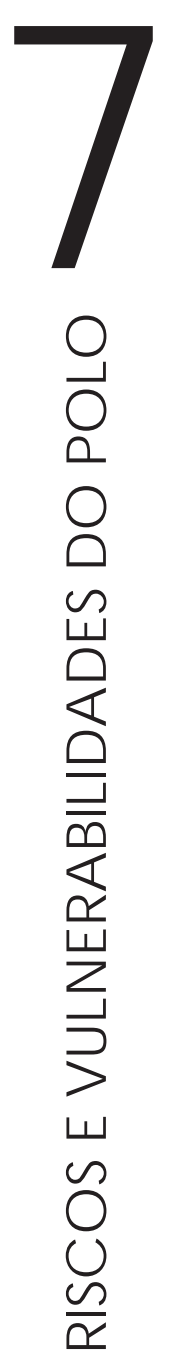

Indústrias e governos têm frequentemente explorado a vulnerabilidade econômica e ambiental das comunidades pobres, dos estados pobres, das nações pobres, das regiões pobres para suas operações de risco [...]. Muitas plantas industriais são localizadas na fronteira com as comunidades. Algumas são tão próximas dos residentes locais que eles podem ir a pé ao trabalho. Mas geralmente as comunidades são imobilizadas com a pobreza e a poluição, enquanto outras pessoas obtêm os postos de trabalho.

Bullard apud Ascerald (organizador/ 2004) 
234| CAPÍTULO 7 


\section{RISCOS E VULNERABIUDADE DO POLO}

O maior desafio no planejamento e na implementação do Polo Industrial de Anchieta, encontra-se na conciliação de dois propósitos, historicamente considerados dicotômicos, ou seja, crescimento econômico e o desenvolvimento socioambiental. Embora se possam questionar as dimensões analíticas empregadas para entender os diferentes graus de transformação que atingem uma região, é quase unânime que mudanças estão em curso. Portanto, a compreensão acerca das possibilidades de comprometimento das estruturas existentes, seja as sociais, as ambientais, seja as materiais, é de fundamental importância para a tomada de decisões que criem condições objetivas de qualificar e monitorar o ambiente vivido cotidianamente.

A dimensão escalar do projeto "Polo Industrial e de Serviços de Anchieta", cuja proposição reúne um grande número de atividades industriais, suscita o questionamento sobre a capacidade de suporte do município. Os ganhos financeiros com a instalação de novas indústrias, especialmente do setor de siderurgia, são consideráveis para a receita do estado do Espírito Santo; entretanto, a forma como foi estruturado o Polo Industrial no território de Anchieta faz com que se vislumbrem novos cenários e mesmo gargalos negativos. Antevendo-se um cenário de futuro, há uma grande probabilidade de ocorrência de processos predatórios, tais como a insuficiência de infra-estrutura da rede física e de equipamentos comunitários para atendimento às demandas; a fragmentação de áreas ambientalmente sensíveis; a ineficiência dos recursos hídricos; o déficit habitacional e o intenso fluxo migratório. Nesse sentido, ante o cenário atual, há que vislumbrar as perspectivas futuras, mediante estudos e projeções estatísticas de fontes oficiais, entre os quais, o da Avaliação Ambiental Estratégica (ES em Ação, AAE, 2008).

É interessante ressaltar aqui a noção de vulnerabilidade. Rodriguez ${ }^{106}$, argumenta que a expressão "vulnerabilidade" precede a identificação dos grupos ou processos em risco, já que exige especificar e determinar tanto a capacidade de resposta das unidades de referência como sua habilidade

106 RODRIGUEZ (2001), apud DESCHAMPS, Marley. Estudo sobre a vulnerabilidade socioambiental na Região Metropolitana de Curitiba. Cadernos Metrópole, n. 19. Semestral. INSS 15172422. pp. $191-219.1^{\circ}$ sem 2008 
para adaptar-se ativamente. Nesse contexto, para o autor, a fragilidade institucional e a falta de equidade socioeconômica podem ser consideradas riscos, pois obstruem o desenvolvimento socioeconômico e impedem a coesão social.

Numa situação específica, como um acontecimento ambiental danoso, tais fatores passam a debilitar a capacidade de resposta de alguns segmentos da sociedade. Dessa forma, vulnerabilidade implica risco, fragilidade ou dano. Três situações são necessárias para que se produza um dano: um evento potencialmente adverso, ou seja, um risco, que pode ser exógeno ou endógeno; a incapacidade de responder positivamente diante de tal contingência; a impossibilidade para adaptar-se ao novo cenário gerado pela materialização do risco.

Ainda segundo Rodriguez há um estreito vínculo entre "microestrutura social" (a situação dos ativos de diversas naturezas das famílias, os quais podem contribuir para a mobilidade social ou melhorar as condições de vida) e a "macroestrutura social" (disponibilidade de estrutura para as famílias e seus membros); já a vulnerabilidade social consistiria no desajuste entre essas duas dimensões. A falta de ativos e/ou a indisponibilidade de estruturas capazes de dar respostas a essas vulnerabilidades significam "desvantagens sociais", ou seja, condições sociais que afetam negativamente o desempenho de co-munidades, lares e pessoas. Essa condição implica menos acessos (conhecimento e/ou disponibilidade) e menos capacidade de gestão dos recursos e das oportunidades que a sociedade entrega para o desenvolvimento de seus membros.

Giddens (1991) afirma que, num contexto em que as práticas sociais são revistas cotidianamente mediante uma profusão de informações, o risco atual depende cada vez menos das contingências naturais e cada vez mais de intervenções sociais e culturais, que, em alguns casos, Nesse sentido, o futuro é altamente incerto, e todos os atores, em princípio, são passíveis de danos, ou seja, são vulneráveis ${ }^{107}$.

\subsection{Sobrecarga na estrutura física e social}

107 GIDDENS, A. As conseqüências da modernidade. Universidade Estadual Paulista. São Paulo. 1991 
A principal repercussão gerada pelos grandes projetos sobre os municípios que integram a Microrregião Expandida Sul ${ }^{108}$ reside na pressão decorrente da mobilidade a ser exercida na demanda por serviços públicos e de infraestrutura. As fragilidades são muito mais evidentes em Anchieta, Guarapari e Piúma, uma vez que são economias ainda pouco integradas com as atividades ligadas aos grandes empreendimentos industriais.

O município de Anchieta, com uma população aproximada de 20 mil habitantes, é alvo de reflexão sobre as perspectivas futuras, quando se pensa que, no "pico" das instalações e implementação dos projetos inerentes ao Polo, a cidade-sede poderá dobrar a sua população. Vale lembrar que, entre 1970 e 1980, tanto Anchieta quanto Guarapari passaram por mudanças em suas estruturas socioespaciais, praticamente triplicando a população urbana e, ao mesmo tempo, reduzindo à metade suas respectivas populações rurais.

O município de Piúma passou pelo mesmo processo de crescimento populacional e adensamento urbano na década seguinte, entre 1980 e 1991, embora com menos intensidade. Apesar disso, Piúma ${ }^{109}$ é o mais densamente povoado entre os três municípios. Essas mudanças refletidas na dinâmica urbana e populacional dos referidos municípios se deram especialmente em virtude da instalação e ampliação da SAMARCO Mineradora, desde o inicio de sua operação, em 1977, até o ano de 2008, quando a empresa expandiu sua capacidade de produção com o "Projeto de Terceira Pelotização". Estima-se que foram feitas em torno de quatro mil contratações temporárias nessa última ampliação.

Verificou-se que o pouco adensamento de edificações no território do distrito-sede de Anchieta decorre muito em função da situação fundiária, pois grande parte das terras urbanas é de propriedade da SAMARCO. Portanto, existe uma grande probabilidade de expansão de loteamentos

108 Os municípios de Guarapari, Anchieta e Piúma estão dispostos espacialmente nesta sequência, do norte para o sul, que, em conjunto, representam 2,33\% da área total do território do Espírito Santo. Destacam-se Guarapari e Anchieta como os maiores em território, enquanto Piúma é muito menor, representando apenas $12,5 \%$ da área total de Guarapari.

109 O município de Piúma, segundo a contagem populacional de 2007, tem 222 habitantes por $\mathrm{km}^{2}$, seguido de Guarapari, com 169 hab. $/ \mathrm{km}^{2}$, e de Anchieta, com somente $47 \mathrm{hab} . / \mathrm{km}^{2}$, bem abaixo da média estadual de $72,57 \mathrm{hab} . / \mathrm{km}^{2}$. Fonte: ESPÍRITO SANTO EM AÇÃO. Avaliação Ambiental Estratégica do Pólo Industrial e de Serviços de Anchieta - ES.Vitória,2008 
Tabela 17

Anchieta Estimativa de população e fluxo de pessoas 2007-2020

\begin{tabular}{r|r|r|r|r|r|r}
\multicolumn{1}{r|}{ Ano } & $\begin{array}{c}\text { População } \\
\text { Residente }\end{array}$ & Fx.Saz. Alta & Fx.Saz.baixa & Obr+ Op & Total Alta & Total Baixa \\
\hline 2007 & 19.459 & 20.941 & 7.539 & 3.300 & 43.700 & 30.298 \\
\hline 2008 & 19.679 & 21.177 & 7.624 & 3.300 & 44.156 & 30.603 \\
\hline 2009 & 20.216 & 21.755 & 7.832 & 5.850 & 47.821 & 33.898 \\
\hline 2010 & 20.924 & 22.517 & 8.106 & 16.200 & 59.640 & 45.230 \\
\hline 2011 & 21.727 & 23.381 & 8.417 & 22.300 & 67.409 & 52.444 \\
\hline 2012 & 22.651 & 24.375 & 8.775 & 16.900 & 63.926 & 48.326 \\
\hline 2013 & 23.380 & 25.160 & 9.058 & 12.550 & 61.090 & 44.987 \\
\hline 2015 & 24.077 & 25.910 & 9.327 & 11.550 & 61.536 & 44.954 \\
\hline 2016 & 24.686 & 26.565 & 9.563 & 12.300 & 63.551 & 46.549 \\
\hline 2017 & 25.268 & 27.192 & 9.789 & 14.750 & 67.211 & 49.808 \\
\hline 2018 & 25.827 & 27.793 & 10.006 & 14.650 & 68.270 & 50.482 \\
\hline 2019 & 26.325 & 28.330 & 10.199 & 13.150 & 67.805 & 49.674 \\
\hline 2020 & 26.807 & 28.848 & 10.385 & 11.850 & 67.505 & 49.042 \\
\hline & 27.271 & 29.347 & 10.565 & 11.850 & 68.468 & 49.686 \\
\hline
\end{tabular}

Fonte: ES EM AÇÃO/ Avaliação Ambiental Estratégica.2008.

\section{Tabela 18}

Projeção de crescimento da população em Anchieta com Polo Industrial

\begin{tabular}{|c|c|c|c|c|c|c|}
\hline \multirow[b]{2}{*}{ Projetos Previstos Pólo Industrial Anchieta } & \multicolumn{6}{|c|}{ Projeção de cresc imento da população } \\
\hline & 2000 & 2005 & 2010 & 2015 & 2020 & 2025 \\
\hline Petróleo e ativida des correlatas & \multirow{5}{*}{19.176} & \multirow{5}{*}{21.728} & \multirow{5}{*}{34.356} & \multirow{5}{*}{46.553} & \multirow{5}{*}{61.105} & \multirow{5}{*}{72.679} \\
\hline Ampliação da SAMARCO & & & & & & \\
\hline Ferrovia Litorânea Sul & & & & & & \\
\hline Diversific ação e a mpliação do Porto Ubú & & & & & & \\
\hline $\begin{array}{l}\text { Lógica de expansão da Região } \\
\text { Metropolitana }\end{array}$ & & & & & & \\
\hline
\end{tabular}

Fonte: ESPAÇO ARQUITETURA E CONSTRUÇÃO. Plano Diretor Municipal de Anchieta. 2006

irregulares e assentamentos precários em direção aos municípios vizinhos de Piúma e Guarapari.

Apenas com essa amostragem empírica, ou seja, uma profunda alteração na dinâmica urbana e rural de Anchieta, Piúma e Guarapari, a partir da inserção da atividade industrial, já se supõem grandes transformações que haverão de impactar a região, com reflexos e proporções ainda maiores, com a implantação de um Polo Industrial e de Serviços. Vários estudos 
realizados - Avaliação Ambiental Estratégica, Plano Diretor Municipal de Anchieta e estudos de impaco do Polo promovidos pela SETADES ${ }^{110}$ apontam na direção de migração desenfreada e aumento considerável da população nos próximos anos, caso se efetive a instalação do Polo Industrial (Tabelas 17 e 18). Segundo José Carlos Pigatti, gerente da SETADES, está previsto que o município de Anchieta poderá gerar 20 (vinte) mil empregos diretos e indiretos, e que, após execução dos projetos, essa população economicamente ativa ficará restrita a apenas dois mil trabalhadores operando no Polo.

É possível vislumbrar a indicação de que, mantidas as atuais perspectivas de aumento significativo da densidade populacional na região do Polo Industrial de Anchieta, os municípios terão problemas na absorção do incremento populacional previsto, uma vez que essa absoração exigirá a abertura de novas áreas para urbanização e moradias, com custos sociais proporcionais às densidades previstas. Além da questão de que os projetos não irão absorver a grande maioria de trabalhadores, pois exigem mão de obra qualificada na gestão e posterior continuidade dos empreendimentos, é fato que essa grande massa de trabalhadores não absorvidos nos processos subsequentes à implementação do Polo irá gerar um mercado de trabalho informal com baixo nível de renda. Nesse contexto, há como antever cenários futuros indesejáveis, como o aumento do número de invasões e loteamentos clandestinos em toda a região, aumento da violência urbana e do tráfico de entorpecentes, além da insuficiência de serviços básicos para o atendimento à demanda, tais como saneamento, escolas e postos de saúde para atendimento às classes carentes.

Os municípios de Guarapari e Piúma, desde já, começam a refletir os impactos advindos dessa especulação acerca dos projetos. O processo aumenta o número de loteamentos clandestinos e invasões, que, diariamente alocam migrantes procedentes do interior e principalmente de estados vizinhos, como Minas, Bahia e Rio de Janeiro. Segundo a SETADES (2008), constata-se que, ante a ausência de moradias e alojamentos adequados nos municípios de Anchieta e Piúma, pousadas e residências na região das praias estão sendo adaptadas para acomodar 60 trabalhadores em cada

110 SETADES - Secretaria de Estado de Trabalho Assistência e Desenvolvimento Social do Espírito Santo. 
uma delas e causando graves problemas sociais, dentre eles, a gravidez precoce e o aumento da violência. Esse processo já vem ocorrendo desde 2007 com a divulgação dos projetos e a chegada de empresas para formulação de estudos.

O percentual de gestações na adolescência nos municípios do Polo e no estado como um todo não apresentou grandes variações entre os anos 2000 e 2006. Entretanto, no período recente (2007 e 2008), esses percentuais variaram entre 17 e 24\% em Anchieta, entre 20 e 27\% em Guarapari e entre 18 e 26\% em Piúma (SETADES, 2008). As pesquisas realizadas pela $\mathrm{AAE}^{111}$, no âmbito regional, constataram que, em relação ao volume de ocorrências de tentativas de homicídios registradas no período (1998/2007), Guarapari detém a maior participação percentual, com aproximadamente 78\% (setenta e oito por cento); Piúma registrou 9\% (nove por cento), e Anchieta 7\% (sete por cento). Esses indicadores tendem a aumentar com o grande número de trabalhadores que estarão se instalando temporariamente no município de Anchieta sem as respectivas famílias, somando-se à precariedade dos serviços de segurança na região, o que favorece a possibilidade de ocorrências do uso de entorpecentes e crimes passionais.

A SETADES registrou ainda, em 2008, grande procura por empregos, especialmente em Anchieta, seguido pelo município de Guarapari, já havendo expectativa de migração proveniente dos estados do norte do Rio de Janeiro e de Minas Gerais (dados do SINES). A administração pública de Anchieta considera que o município possa ter condição de cobrir em oferta de mãodeobra apenas 30\% do total previsto do fluxo migratório (10 mil trabalhadores); portanto, o município vai demandar participação maior dos municípios vizinhos em relação ao provimento da mão de obra de construção civil.

A reflexão sobre o cenário futuro torna tangível o problema social a ser enfrentado depois de uma previsível migração e acomodação dessa população na região atraída pela dinâmica econômica nos primeiros anos de implantação do Pólo. Segundo a SETADES, não existe ainda, nenhum

111 ES EM AÇÃO. Avaliação Ambiental Estratégica do Pólo Industrial de Anchieta (AAE). Vitória. 2008 
horizonte futuro que contemple projetos de grande porte no estado do Espírito Santo que garantam a absorção desta mão de obra potencial pós-implantação do Polo. Além do mais, presume-se que não haja forte integração do Polo com a classe de trabalhadores locais de tradição eminentemente ligada à pesca e ao turismo. As atividades tradicionais podem ser seriamente afetadas, embora com algumas possibilidades de adaptação. Isso quer dizer que as oportunidades que poderão surgir com o Polo Industrial terão que passar pela construção de uma trajetória de aprendizado e de interação, mediante a qualificação da mãodeobra e a dinamização dos setores mais afins com esse tipo de empreendimento (industrial).

Ainda que se considere a construção de uma sede do SENAI, prevista para o município de Anchieta, e a construção do CEFETES, Guarapari ${ }^{112}$ , a SETADES argumenta que essas instituições destinadas à capacitação de mãodeobra devem demorar algum tempo para entrar em funcionamento; portanto, a mão de obra necessária para implementação dos projetos relativos ao Polo apenas estaria capacitada, pelo menos, para daqui a uns três anos (a partir data-base referência da SETADES, 2008). Outro fator preocupante é que a SAMARCO não tem um plano de efetivação e planejamento de mão de obra, uma vez que, para cada mão de obra especializada, o Polo gerará quatro novos empregos indiretos. Por outro lado, é esperada uma aproximação entre os negócios desenvolvidos pelos chamados Grandes Projetos Industriais que operam na Macrorregião Metropolitana e os empreendimentos locais, com possibilidades de geração de renda e de emprego, seja por meio da ampliação das compras de produtos e serviços por parte das grandes empresas no espaço regional, seja pelo estímulo ao desenvolvimento de novos negócios à jusante das cadeias produtivas dos setores mínero-siderúrgico e da celulose. Isso sem contar com a injeção mensal de uma expressiva massa salarial, o que poderá contribuir para a proliferação de pequenos e médios negócios urbanos.

Em Anchieta, município com baixa densidade demográfica, de tradição econômica agrícola, na área rural, e cuja atividade produtiva, na área urbana, está tradicionalmente voltada para a pesca e o turismo, com a previsão de plantas indústriais e outros projetos de porte, os problemas de

112 As referidas obras estão em andamento. 

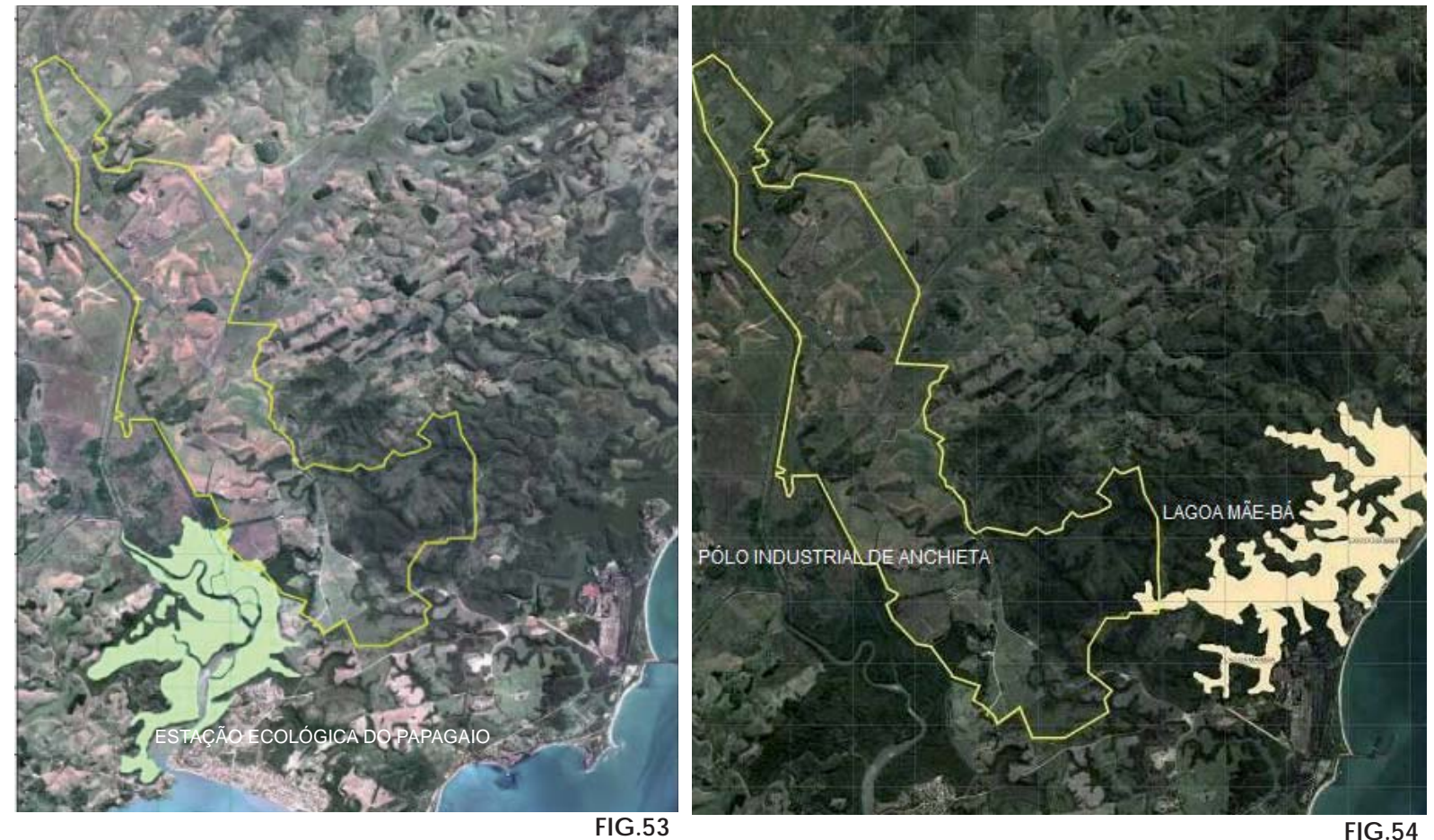

saneamento tendem a se agravar, sobretudo com o crescimento urbano ea expansão das atividades. Para os próximos anos, em virtude do provável problema social que deverá atingir toda a região próxima ao município, todos estes problemas já mencionados tendem a se consolidar como ponta do "iceberg" que faltava para romper a estrutura e compor o núcleo central de impacto no território estadual.

Trabalhando com a possibilidade de realização de cinco, entre os sete investimentos industriais previstos, o incremento na ocupação urbana municipal deverá, até 2025, impor alterações consideráveis nos componentes organizacionais. A criação de polos econômicos é importante para a economia do estado, mas é preciso cuidado e planejamento detalhado da infraestrutura, para evitar problemas e a repetição do quadro verificado na década de 1980, que gerou conflitos estruturais entre as atividades econômicas e a regulação do território metropolitano. Não custa lembrar que os bairros da periferia, principalmente em Vitória, Cariacica, Vila Velha e Serra, surgiram por intermédio de invasões ou assentamentos irregulares, formados, em locais sem infraestrutura, por migrantes de outros estados. Nessa perspectiva, há como antever cenários futuros indesejáveis, o que exigirá uma gestão pública eficiente de modo a compatibilizar os custos sociais proporcionais às densidades previstas.

\section{RG.53}

Localização da Estação Ecológica do Papagaio em relação ao Pólo.

Fonte: ES em Ação. AAE / Cepemar. 2008

FG.54

Localização da Lagoa

Mãe-Bá em relação ao Pólo. Fonte: AAE / Cepemar. 2008 


\subsection{A questão ambiental}

Além das questões de cunho social, os impactos nos municípios referemse especialmente às questões ambientais, dado que a infra estrutura e o suporte biofísico não são capazes de atender às exigências para a instalação da siderurgia e acomodação da mão de obra estimada, o que pressupõe o comprometimento das áreas ambientalmente sensíveis. Deverão aumentar consideravelmente os conflitos em torno de recursos hídricos, já que as indústrias são grandes demandatárias de água.

O complexo mínero-siderúrgico do Polo Anchieta, cuja localização se dá nos limites de áreas de preservação permanente, às margens do Rio Benevente, deverá comprometer os ecossistemas, sobrecarregando as estruturas existentes da região e do seu entorno. Mais de 30\% da área do Polo Industrial e de Serviços de Anchieta tem por característica possuir uma vegetação sob a cobertura da proteção legal. Essa condição enseja uma
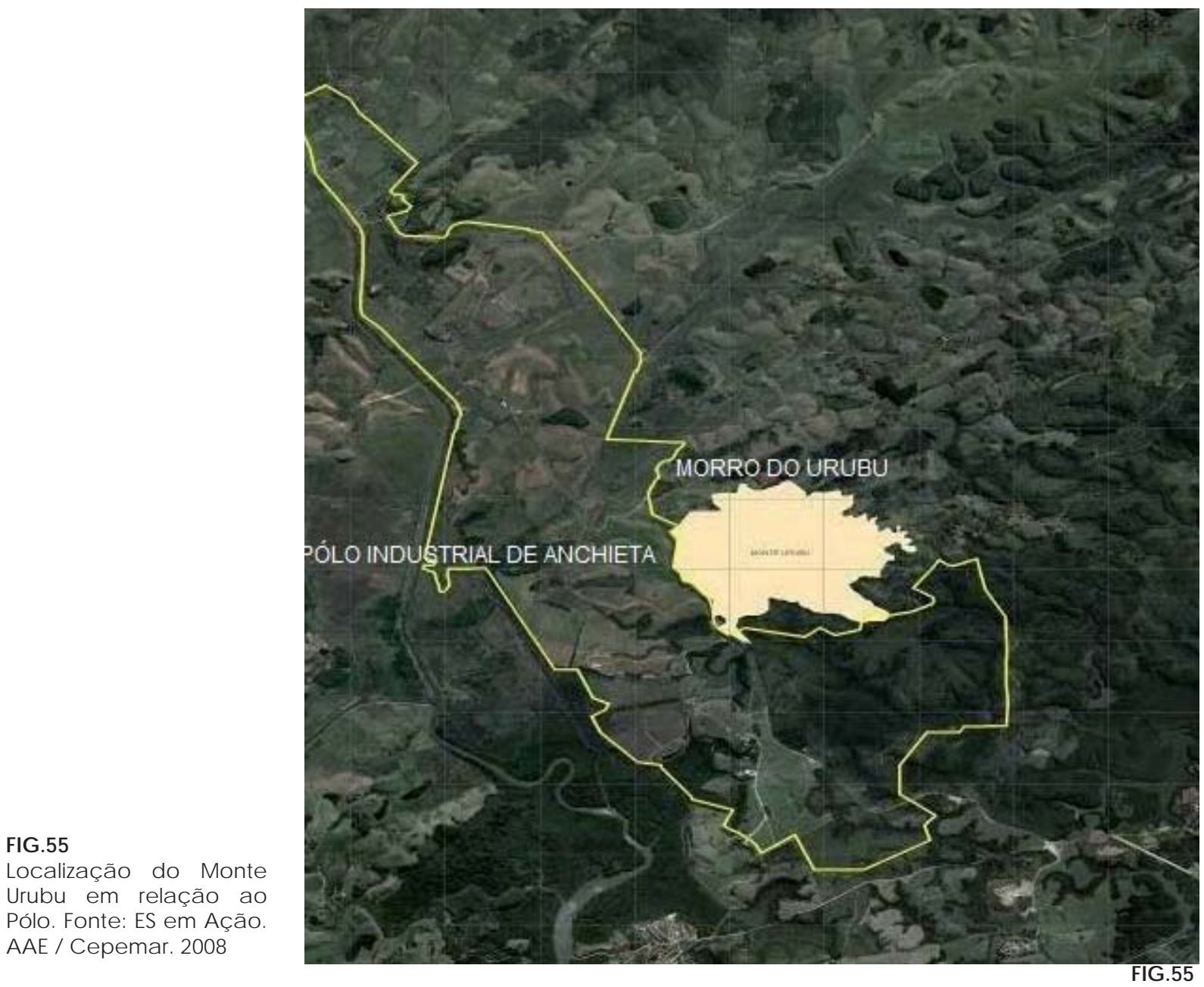


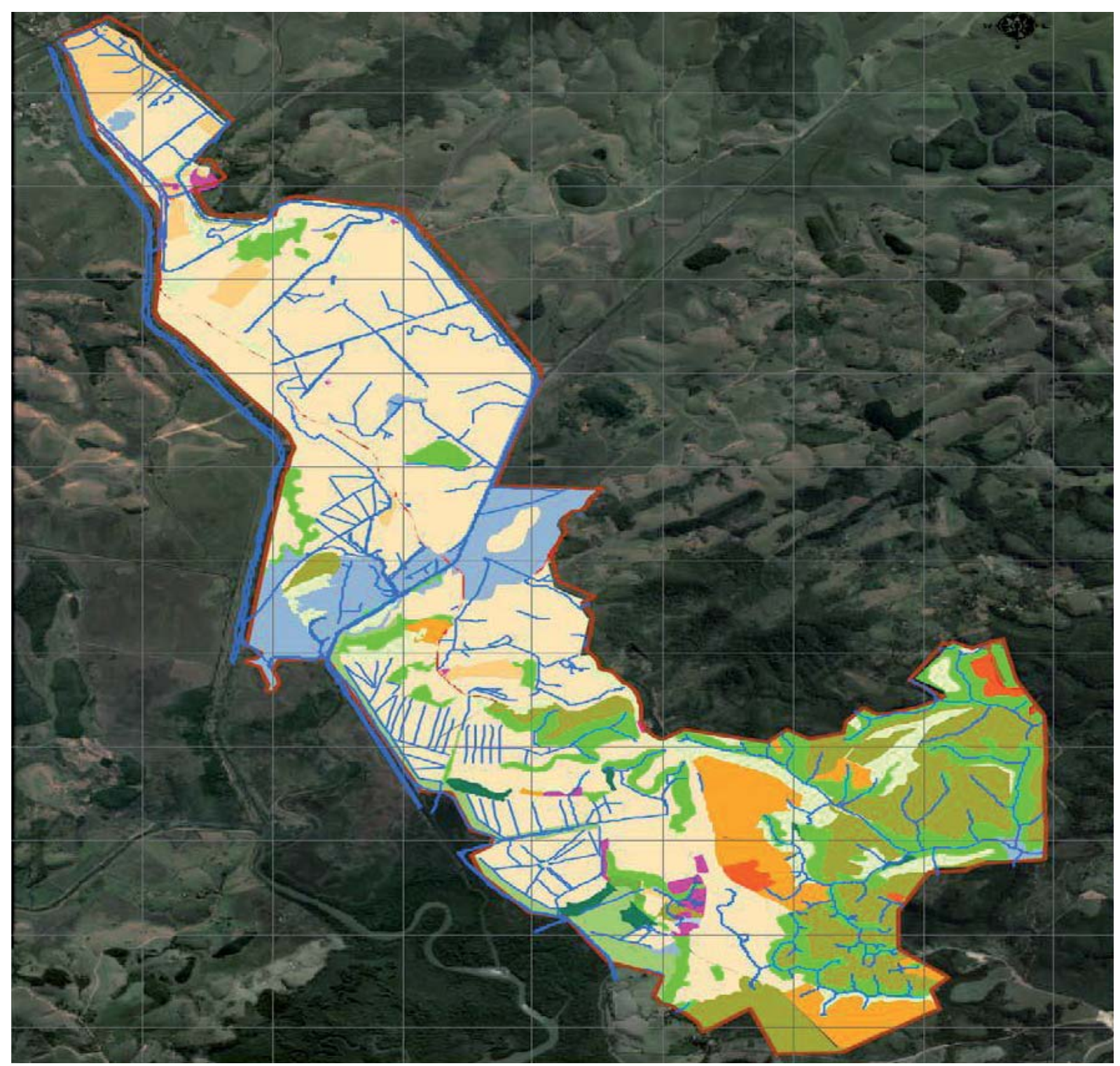

RG.56

atenção maior dispensada a esse aspecto, principalmente em função das definições do uso e ocupação do solo no estabelecimento da área legal destinada ao Polo, o que requer supressão da vegetação. Existem duas unidades de conservação no entorno imediato do Polo: a Estação Ecológica de Papagaio e a Área de Proteção Ambiental da Guanabara (APA). A primeira abrange o ecossistema manguezal, e a segunda refere-se ao ecossistema de restinga. Há também o Monte Urubu, considerado pelo Plano Diretor Municipal de Anchieta como área prioritária para conservação, e a lagoa Mãe-Bá, considerada como a segunda maior lagoa do estado. São de esperar interferências nessas unidades, que, sistematizadas ao longo do tempo com a implantação do Polo, correm o risco de até desaparecer, pelo

RG.56

Mapa da Distribuição das áreas de vegetação protegidas por lei-APP's, no interior do Pólo. Fonte: ESem Ação. AAE/ Cepemar. 2008 
comprometimento de seus sistemas.

A existência de zonas de interesse ambiental, unidades de conservação e monumentos naturais protegidos no entorno do Polo Industrial, se inseridos num contexto de expansão da atividade industrial e da urbanização sem que haja um monitoramento eficaz por parte do poder público, pode propiciar uma deterioração gradativa de tais áreas, comprometendo a estrutura ambiental e de tradição cultural do território em questão. Somado a isso, os impactos ambientais advindos da instalação do Polo incidiriam diretamente sobre os rios e cursos d'água. A qualidade das águas nos córregos e lagoas encontra-se comprometida, com tendência a influir nos usos potenciais dessa reserva hídrica. Considerando que a atividade pesqueira está muito relacionada com o turismo, que também se utiliza dos recursos naturais da cidade, qualquer alteração ambiental implica alteração dessas atividades e, por consequência, da estrutura social.

Para ilustrar o descaso que tem ocorrido no município de Anchieta em relação à preservação dos recursos naturais, cito a Lagoa Icaraí, cujo destino parece selado como o destino dos demais recursos hídricos, em geral, por ações da própria prefeitura municipal, que vem realizando sucessivos aterros em áreas alagadiças próxima à lagoa. Rios e lagoas, além de serem receptores de esgotos, agrotóxicos e lixo, têm suas nascentes soterradas e matas ciliares destruídas. ${ }^{113}$

Há que se considerar também a proposta de implementação de um corredor ecológico entre a região da Estação Ecológica Papagaio e o Monte Urubu, previsto no Plano Diretor Municipal de Anchieta. O corredor ecológico proposto tem por objetivo interligar vegetação de mangue com fragmento de floresta secundária em diferentes estágios de regeneração. $\mathrm{Na}$ verdade, o corredor proposto pelo Plano Diretor Municipal trata de fisionomias bastante distintas em estrutura e composição da vegetação e da fauna, compreendidas em diferentes espécies e grupos tróficos.

Os corredores enquanto elementos da estrutura da paisagem resultam da intensificação de processos naturais ou sociais. Um conjunto de fragmen-

113 Fonte: ONG Progaia e Fórum de Entidades do Litoral Sul do ES, 2008. 
tos, resultante da compartimentação da unidade de paisagem, dispostos linearmente, definem um corredor. Os corredores podem ser contínuos ou interrompidos, variando de acordo com a intensidade dos fenômenos que neles ocorrem e em função dos fluxos e fixos que deles fazem parte. No intuito de avaliar a efetiva conexão do corredor, algumas considerações devem ser observadas sob o ponto de vista técnico:

- Os corredores constituem-se em alternativas de interligação com fins a intensificar os fluxos de energia, insumos e populações.

- Um fator importante na efetivação de um corredor ecológico é a ligação de ambientes semelhantes, pois ambientes muito diferentes favorecerá temporariamente apenas as espécies da fauna adaptadas aos dois ambientes. ( ALMEIDA, 1995)

- As heterogeneidades próprias de cada corredor se expressam por meio de especificidades do meio bio-geofísico, bem como de processos sociais. As espécies mais adaptadas às pressões externas passam a utilizar com freqüência o corredor, aumentando a densidade de sua população.

Compreender a dinâmica socioambiental inerente ao espaço urbano requer um esforço que faça jus à complexidade e à diversidade dos fatores envolvidos. O desenvolvimento deve ser visto como uma oportunidade para aperfeiçoar a qualidade ambiental e reforçar a existência dos corredores, independente da escala. Preocupante é a localização do Polo bem próxima de grande área de manguezal, que encontra expressiva representatividade na Estação Ecológica do Papagaio. Os manguezais funcionam como barreiras naturais contra os mecanismos da erosão provocados pela ação das marés, retendo, entre suas raízes, os sedimentos provenientes das encostas, carreados pelos rios. Na ocupação de nichos especializados como o mangue, cada ligação na cadeia é ocupada por espécies adaptadas a um objetivo particular. Assim, nichos convergem espécies especializadas e tornam-se intolerantes enquanto sistemas maduros. É um sistema complexo, no qual fluxo de matéria e energia, produzido pelo sistema, é usado pelo próprio sistema de forma eficiente. Qualquer quebra pode ser fatal para a regeneração desse especialíssimo ecossistema. Já a floresta tropical é muito resistente, porém pouco resiliente, ou seja, apresenta pequena capacidade de se restabelecer, e, principalmente quando os processos sociais 
atingem uma grande área, o colapso do sistema pode ser total. O mangue, além de desempenhar função de recarga dos ecossistemas, tem sua importância social, uma vez que é fonte de renda e alimentação (BARBOSA, 2005). Estando a Estação Ecológica do Papagaio localizada nos limites imediatos do Polo, os riscos são iminentes.

\subsection{1 Água: impresc indível para o funcionamento do Polo Industrial}

O município de Anchieta é privilegiado quanto à rede hidrográfica. Em face da urbanização, da presença da atividade industrial mineradora, do quadro de agressão ambiental e do processo de supressão da vegetação nas áreas rurais, tem-se uma diminuição progressiva das reservas hídricas, levando o município a apresentar problemas em relação à disponibilidade de água potável.

A Bacia do Rio Benevente é formada pelos municípios de Anchieta, Alfredo Chaves, Iconha, Guarapari e Piúma. A bacia tem uma área de drenagem de aproximadamente $1.260 \mathrm{~km}^{2}$ e sua disponibilidade hídrica é estimada em $30 \mathrm{~m}^{3} / \mathrm{s}$ (Estação Fluviométrica do Benevente). O rio Benevente vem sofrendo, em sua parte baixa, um processo muito rápido de ocupação. Hoje, o rio já enfrenta problemas, como a poluição por esgotos, a contaminação por agrotóxicos e o assoreamento causado pelo desmatamento. Junte-se a esses fatores negativos a ausência de um plano diretor florestal e de uso e ocupação do solo para a bacia.

Aos problemas de degradação ambiental dos recursos hídricos já existentes, soma-se a questão do abastecimento de água doce necessária para o bom desempenho do Polo Industrial e de Serviços de Anchieta, que irá sobrecarregar consideravelmente o sistema. O uso da água para atividade industrial é caracterizado legalmente como não prioritário em relação ao consumo humano e à dessedentação de animais. Portanto, a concessão de uso da água passa, necessariamente, pela análise da disponibilidade de água após subtração das demandas relativas a esses usos e às outorgas relativas a outros usos, tais como abastecimento industrial e irrigação, já obtidas anteriormente com a instalação da SAMARCO.

A política de recursos hídricos do estado do Espírito Santo, descrita pela 


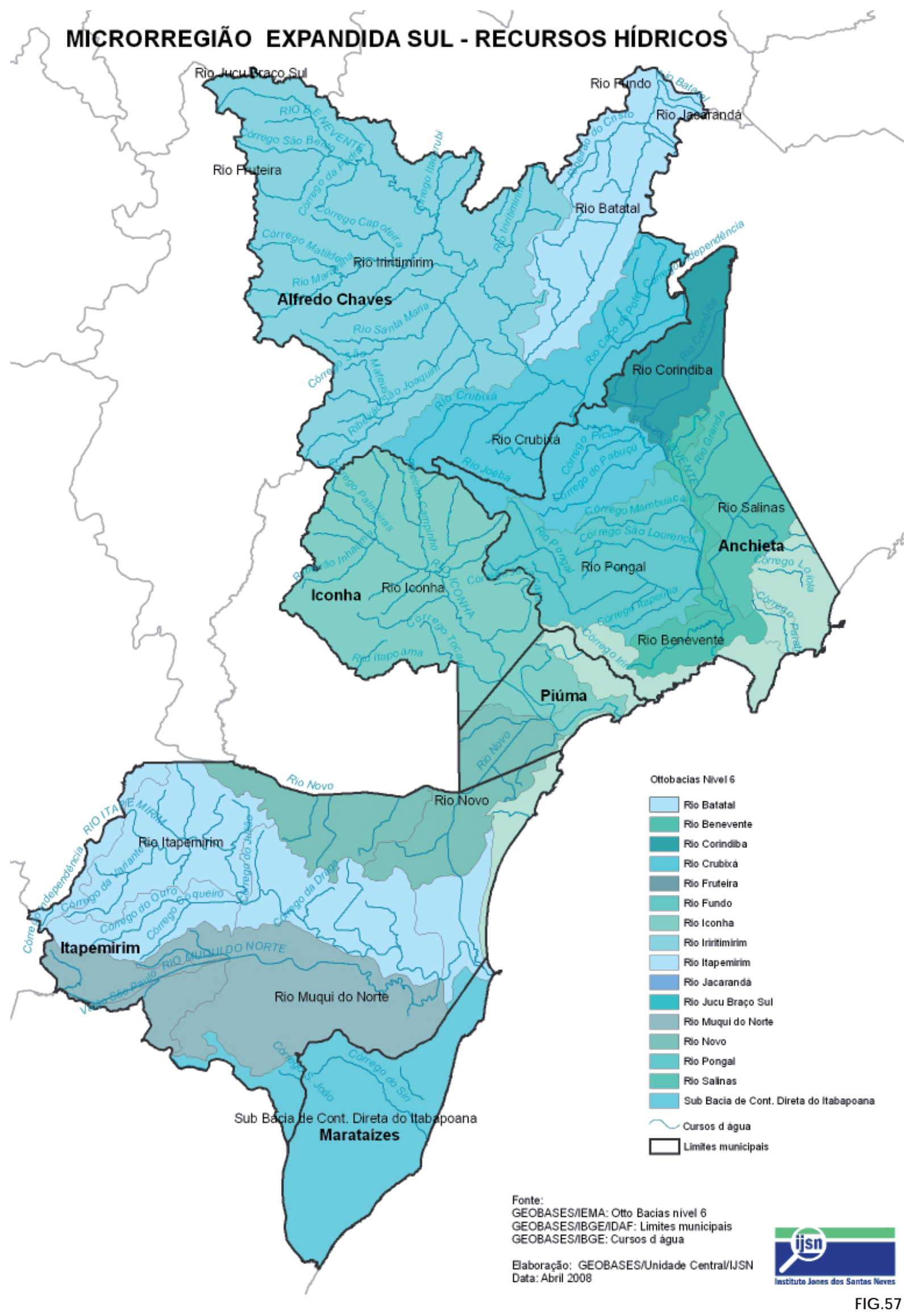


Tabela 19

Quadro resumo de demandas atuais, vazões outorgadase projeções de demandas para 2012 e 2018 (litros/s)

\begin{tabular}{|c|c|c|c|c|}
\hline \multirow{2}{*}{ Setores } & \multirow{2}{*}{$\begin{array}{l}\text { Demanda } \\
\text { Atual }\end{array}$} & \multirow{2}{*}{$\begin{array}{c}\text { Outorgas } \\
\text { emitidas } \\
\text { IEMA }\end{array}$} & \multicolumn{2}{|c|}{ Projeção Demanda Futura } \\
\hline & & & 2012 & 2018 \\
\hline CESAN (População) & 464,3 & 464,3 & 900 & 1.100 \\
\hline $\begin{array}{l}\text { SAAE (População - Alfredo } \\
\text { Chaves) }\end{array}$ & 36 & - & 36 & 37 \\
\hline INCAPER (Agricultura) & $1.780,00$ & 14,9 & 1877 & 2.318 \\
\hline Indústria & - & - & 900 & 1.329 \\
\hline Outros & - & - & - & - \\
\hline Total & $2.280,30$ & 479,2 & 3.713 & 4.784 \\
\hline
\end{tabular}

Fonte: ESEM AÇÃO. AAE com base nos dados da Cesan, Incaper, lema, Aderes. 2008

Lei 5.818/98, está atualmente em fase de implantação, já existindo o Conselho Estadual de Recursos Hídricos e alguns comitês de bacias, incluindo os que abrangem as bacias dos rios Benevente e Novo. Entre os instrumentos da lei, há a Instrução Normativa (2005) que estabelece os procedimentos administrativos e os critérios técnicos referentes à outorga de direito dos usos dos recursos hídricos em corpos d'água estaduais. Esta instrução estabelece como vazão de referência para rios perenes, como nos casos do Benevente, Iconha e Novo, a vazão Q7,10. Entre os critérios de outorga, podem ser citados os seguintes: ${ }^{114}$

- O somatório das vazões outorgadas fica limitado a 50\% da vazão de referência.

- À jusante de cada uso ou interferência deverá ser garantido o fluxo residual mínimo de $50 \%$ da vazão de referência.

- Nenhum usuário receberá outorga superior a $25 \%$ da vazão de referência para um mesmo uso.

HG.57

Recursos Hídricos da Microrregião Metrópole Expandida Sul. Fonte: GEOBASES IJ SN
Para avaliação e análise da relação Disponibilidade/ Demanda relativa ao rio Benevente (Anchieta), a Avaliação Ambiental Estratégica (AAE, 2008, p.169-170) considerou três estudos hidrológicos de regionalização de vazões:

114 ES EM AÇÃO. Avaliação Ambiental Estratégica do Pólo Industrial de Anchieta. 2008. p.169 

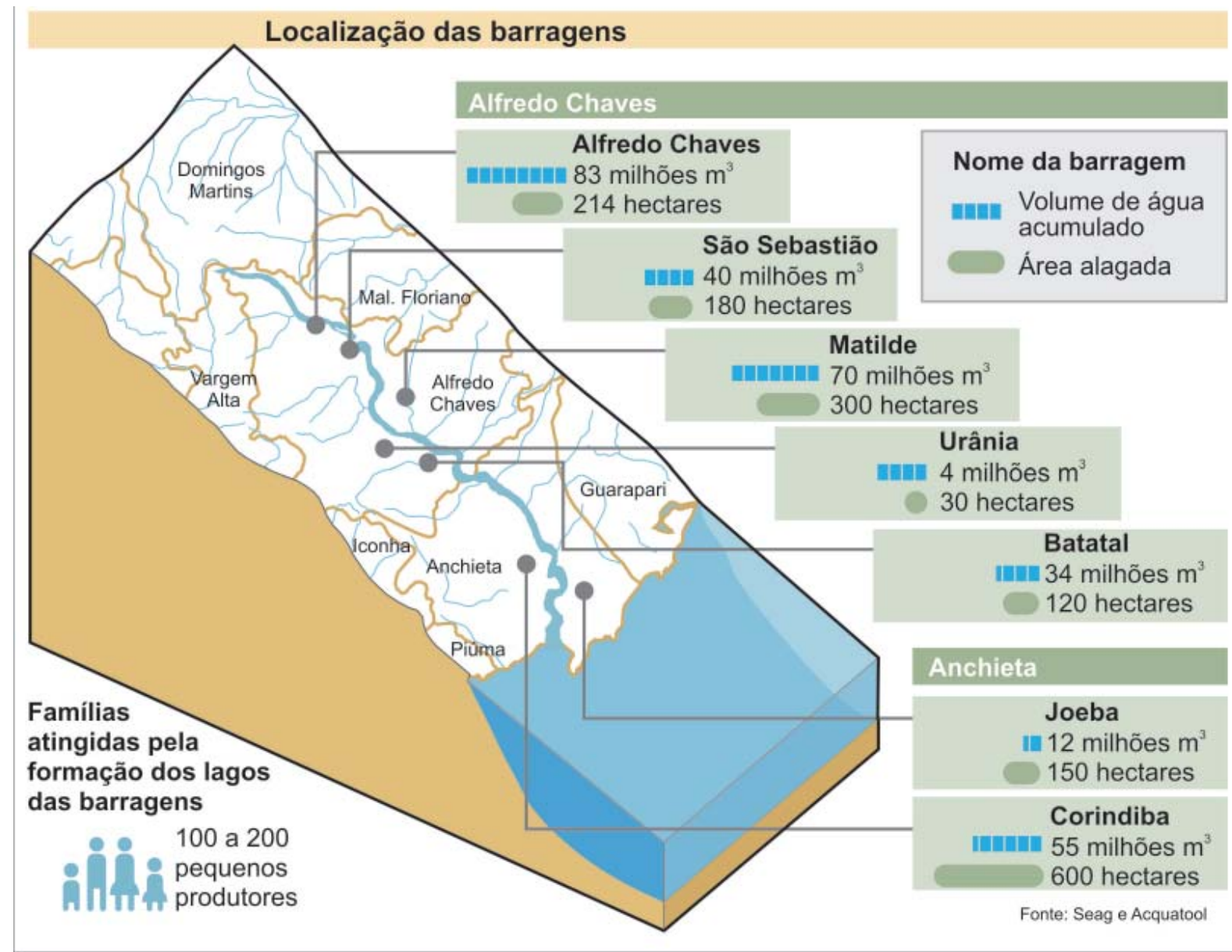

$\mathrm{m}^{3}$

Urânia

4 milhões $\mathrm{m}^{3}$

30 hectares

\section{Batatal}

IIIIIII 34 milhões $\mathrm{m}^{3}$

120 hectares

Anchieta

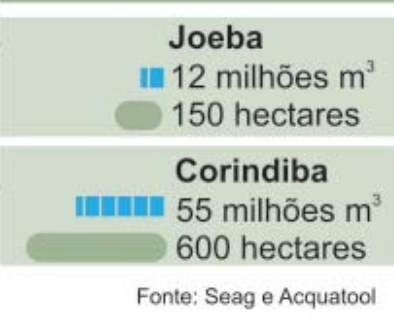

1. o Plano Estadual de Recursos Hídricos, que estima vazão de vazão de

RG.58

FG.58 referência Q7,10 : 8,57 m³ $/ \mathrm{s}$ ou 8.570 litros $/ \mathrm{s}^{115}$;

2. a concessionária de água CESAN estima vazão de referência $\mathrm{Q} 7,10$ $4,92 \mathrm{~m}^{3} / \mathrm{s}$ ou $4.920 \mathrm{litros} / \mathrm{s}$;

3. o estudo intitulado "Regionalização de Vazões Q7.10 no Estado do Espírito Santo", desenvolvido pelo Programa de Pós-Graduação em Engenharia Ambiental da Universidade Federal do Espírito Santo, estimou uma vazão de referência Q7,10 de $4,68 \mathrm{~m}^{3} / \mathrm{s}$ ou 4.680 litros/s.

A vazão mínima de referência Q7,10, estimada para o rio Benevente, em

115 A AAE ( 2008) ressalta que este dado pode estar sobrevalorado pelo fato do estudo de regionalização realizado à época, devido à metodologia adotada, ter considerado como período de regionalização as décadas de 1960 a 1990, não considerando períodos de seca anteriores, como o ocorrido entre 1952 e 1956, nem posteriores, como o do final da década de 1990. Observa-se ainda que contribui para a superestimativa o fato de que o estudo de regionalização foi realizado considerando vazões registradas no posto fluviométrico localizado em Matilde, na porção mais alta da bacia hidrográfica do rio Benevente, em cuja sub-bacia ocorrem as maiores precipitações pluviométricas médias no estado do Espírito Santo.

Desenho esquemático do estudo construção das barragens na microrregião sul para aumento do consumo de água com fins a viabilizar a demanda do Pólo Industrial. Fonte: SEAG / Aquatool. Infográfic 0 . A Gazeta, 31 ago 2008. 
Jabaquara, nos três estudos realizados para estimar abastecimento de água do Polo, é da ordem de 4.680 litros/s. Considerando os dispositivos da Instrução Normativa nº. 019/IEMA, que define 50\% da vazão mínima Q7,10 como sendo a vazão outorgável, a vazão máxima outorgável para o Polo seria de apenas 2.340 litros/s; portanto, um valor muito inferior ao necessário para a demanda do Pólo . Poder-se-ia inferir a existência de um déficit, no ano de 2018, da ordem de 2.400 litros/s para o atendimento às exigências legais quanto à emissão de outorgas para usos da água (AAE, 2008, p.174). Somente por essa avaliação da capacidade hídrica, o Polo Industrial, especialmente no atendimento à siderurgia, está muito provavelmente fadado ao insucesso, caso não se encontrem alternativas para fornecimento da água.

$\mathrm{Na}$ época dos estudos de viabilidade para implantação da siderúrgica, o Governo do Estado, através da SEAG, ${ }^{116}$ visando solucionar a demanda da água para o Polo, planejava construir sete barragens nos municípios de Alfredo Chaves e Anchieta, ao longo do Rio Benevente e de seus afluentes. O objetivo do governo era potencializar o consumo de água da região, que deve aumentar consideravelmente após o pleno funcionamento do Polo Industrial.

Desde o ano de 2007, já havia a previsão da instalação da siderúrgica, em parceria com a Vale, no município de Anchieta. A agilidade do governo do Estado em negociar com a CVRD e a Baosteel garantiu o projeto. Os chineses instalaram-se em Vitória para realização de estudos visando à efetiva implantação da siderúrgica. O empreendimento não só traria um investimento bilionário para o Estado, mas também estaria associado a outros investimentos na área de logística: a construção de um superporto na região de Ubu, capacitado para receber navios gigantes, e a Ferrovia Sul Litorânea.

Os estudos desenvolvidos pela empresa Acquatool estima em 2 mil hectares a área total a ser alagada pelas sete barragens que comporiam sete lagoas (Figura 58). A construção das barragens permitiria uma vazão de 9 mil litros/ segundo, volume superior ao consumo esperado após a construção

116 SEAG: Secretaria da Agricultura, Abastecimento, Aqüicultura e Pesca do Governo do Estado do Espírito Santo 
do Pólo Industrial (SEAG/ Aquatool,2008). Cabe, entretanto, observar que sistemas de regularizações de vazão podem requerer reservatórios de grandes dimensões, muitas vezes inviáveis do ponto de vista econômico e ambiental. Como foi apontado na simulação do estudo, a mais importante barragem denominada Alfredo Chaves, iria acumular 83 bilhões de litros de água e poderia atingir 40 a 50 propriedades. As barragens, segundo Pedro Molinas, engenheiro de recursos hídricos da empresa Aquatool, teriam a função de reduzir o impacto ecossistêmico no Rio Benevente, tais como mortandade de peixes, com a provável salinização da água, e redução do volume de água dos afluentes, quando da retirada da água do rio para fornecimento às indústrias. ${ }^{117}$

Tendo em vista, uma redução de consumo de água doce por parte do Polo Industrial e de Serviços de Anchieta, atentou-se também para a possibilidade de considerar o uso de água do mar para suprimento de parcela de suas demandas, especialmente para siderurgia, seja na forma bruta para atendimento aos processos de refrigeração, seja na forma dessalinizada, visando à utilização em processos mais específicos. Destaca-se, aqui, no entanto, que além de não ser usual a dessalinização de água do mar para utilização em processos industriais no Brasil, esse processo se caracteriza por apresentar custos expressivamente elevados, fazendo com que a alternativa seja pouco viável.

Alguns dados referentes à Bacia do Benevente devem ser considerados, assim como a sua capacidade de suporte e a expectativa de superação do déficit de atendimento ao Polo com a construção das barragens, conforme segue:

- Área da bacia do Rio Benevente: $1.200 \mathrm{~km}^{2}$

- Vazão do Rio Benevente hoje: 10 mil /litros / segundo

- Consumo de água após a construção do pólo industrial: superior a 5 mil litros/segundo

- Vazão obtida com a construção das barragens: 9 mil litros/ segundo, superior ao consumo esperado após a construção do Pólo Industrial

117 Os estudos das barragens foram feitos em conjunto com o Laboratório de Gestão de Recursos Hídricos da UFES (Universidade Federal do Espírito Santo) por solicitação do Governo do estado Espírito Santo. Parte deste material foi apresentado às comunidades. Fonte: A Gazeta. Governo planeja 7 barragens para atender à siderúrgica. 31/08/1008.p.15 
(Fonte: Acquatool)

Conforme vimos e como os estudos apontam, a demanda por água, com a instalação do Polo, é insuficiente e compromete a capacidade da bacia do Rio Benevente. Quanto aos condicionantes técnicos, deve ser ressaltada a nova necessidade de sistematizar e atualizar os dados da bacia hidrográfica à qual o Polo está efetivamente ligado. Apesar dos conflitos, observáveis quando se dá início a um trabalho entre diferentes órgãos do setor público, a atitude dos técnicos tende a evoluir para um trabalho cooperativo e participativo. Porém, constatam-se frequentes entraves para dar continuidade aos trabalhos em níveis superiores de decisão, o que evidencia a origem das dificuldades encontradas para garantir a qualidade da água em longo prazo.

\subsubsection{A emissão de poluentes do artende a aumentar}

A localização do Polo tem outro condicionante desfavorável no que se refere à questão ambiental: a qualidade do ar. Já existe, em Anchieta, a atividade mínero-siderúrgica operada por três usinas da empresa SAMARCO Mineração. Atualmente, essas usinas já são suficientes para produzir uma contaminação expressiva de poluentes no ambiente atmosférico. A qualidade do ar em Anchieta tem sido comprometida pelas emissões geradas a partir da atividade siderúrgica, sobretudo, no processo de embarque de minério de ferro nos navios atracados no porto de Ubu.

As pilhas de minério ao ar livre sofrem a ação dos ventos, que, num processo similar ao que ocorre em Vitória pela Companhia Siderúrgica de Tubarão (CST), provocam a suspensão do pó. Esse fato, associado ao embarque do minério no porto de Ubu, próximo ao centro urbano de Anchieta, acaba por causar várias doenças respiratórias à população, impactando principalmente os moradores dos balneários de Ubu até Iriri. Segundo estudos da AAE, os registros e análises históricas já indicam que as concentrações de partículas totais em suspensão (PTS) nas localidades de Ubu e Mãe-Bá se encontram em patamares elevados, chegando a alcançar 91\% do limite estabelecido pelo padrão primário da Resolução Conama, 

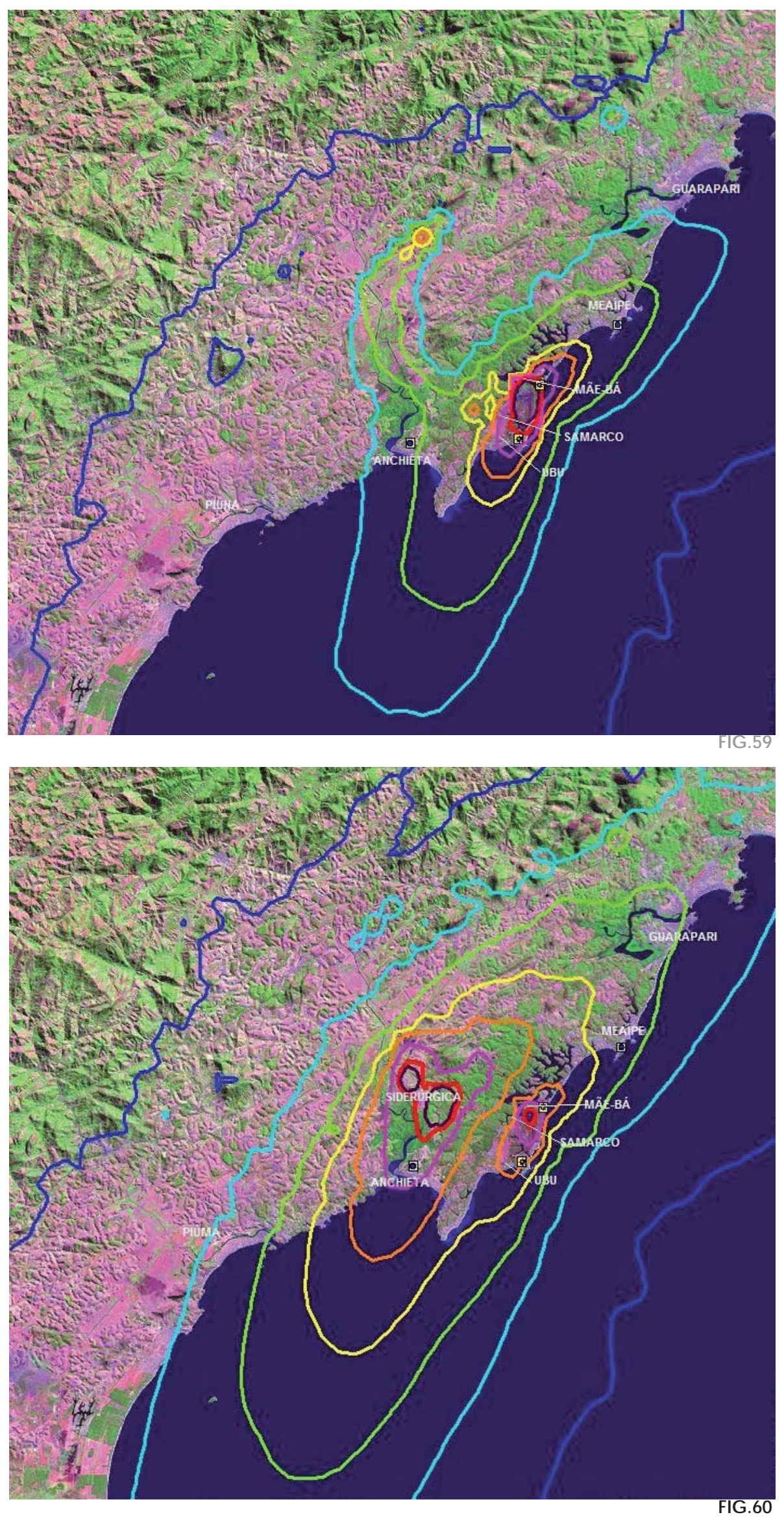

RG.59

Concentração de Partículas Tota is em Suspensão (PTS) - Região de Anchieta e Guarapari - Situação atual. Fonte: ES em Ação. AAE / Cepemar

\section{RG.60}

Concentração de Partículas Tota is em Suspensão (PTS) - Região de Anchieta e Guarapari - Situação prospectiva com a implantação do Pólo. . Fonte: ESem Ação. AAE / Cepemar 


\section{O que será feito para diminuir o pó de minério}

A Vale terá que tomar 4 medidas técnicas para barrar o pó:

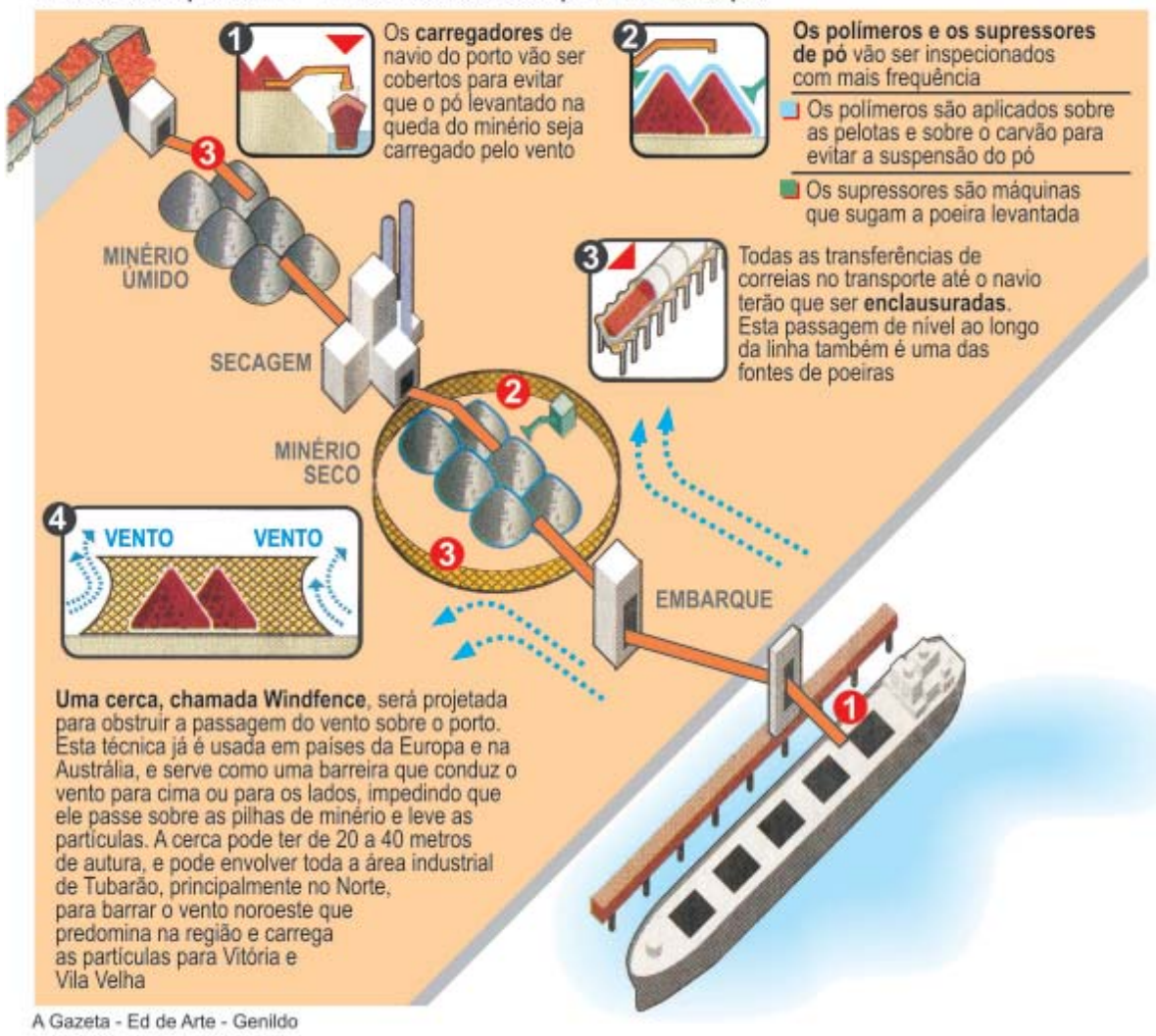

O IEMA e a UFES também são

citados no termo de compromisso

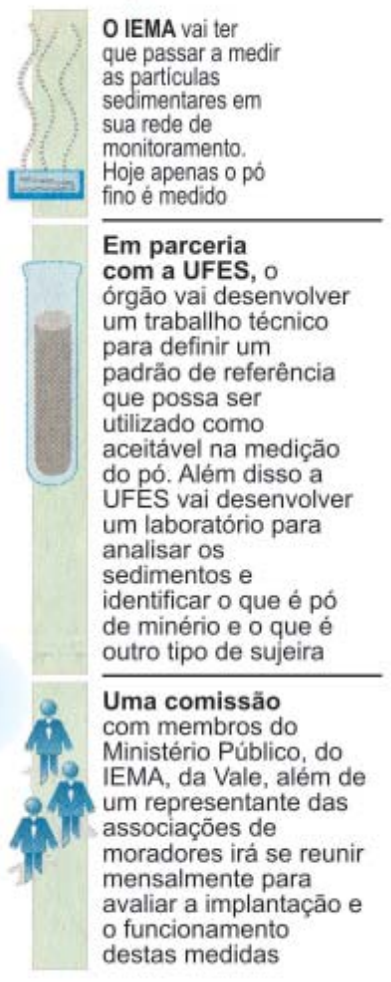

RG.61

\section{PG.61}

Esquema mostrando a implantação de Wind fence para contenção do pó de minério de ferro que atinge a RMGV, requerida pelos moradores através do Ministério Públic o. Fonte: A Gazeta. 15 jun 2007. Tratamento imagens: Eugenio de março de 1990 (AAE, 2008,p.184) ${ }^{118}$. Quanto às concentrações de partículas inaláveis (PI) monitoradas na região, pode-se afirmar que elas se encontram, atualmente, dentro dos padrões estabelecidos pelo Conama. As maiores concentrações de PI foram observadas na estação Mãe-Bá, atingindo cerca de $83,1 \%$ do padrão primário legal vigente.

No cenário do Polo, novos setores urbanos estarão sujeitos a concentrações de poluentes em níveis próximos dos limites estabelecidos pelos padrões vigentes, notadamente na zona a sudoeste das instalações da usina siderúrgica SAMARCO, no município de Anchieta. Segundo estudo da Cepemar ${ }^{119}$,a empresa responsável pela análise ambiental da AAE, se considerada a atual produção e embarque de minério-de-ferro pela SAMAR-

118 Um dos principais parâmetros para a definição da qualidade do ar da região nesta Avaliação Ambiental Estratégica - AAE é a presença de material particulado na atmosfera. Vale ressaltar que, após serem lançados na atmosfera, o material particulado (MP) e o material particulado menor que $10 \mu \mathrm{m}$ (MP10) passam a se denominar de partículas totais em suspensão (PTS) e partículas inaláveis (PI), respectivamente, seguindo a nomenclatura utilizada pela resolução CONAMA 03/1990. 119 Cepemar - empresa contratada pela Aderes (Agência de Desenvolvimento em Rede do Espírito Santo) para fazer diagnóstico ambiental para AAE- Avaliação Ambiental Estratégica. Vitória. 2008. 
CO Mineradora, a emissão de Partículas Totais em Suspensão (PTS) e Partículas Inaláveis (PI) tende a aumentar muito com a efetivação do Pólo Industrial (Figuras 59 e 60). A experiência com a instalação da Companhia Siderúrgica de Tubarão - CST - em Vitória mostra que a atividade provoca altos índices de poluição do ar, com suspensão de partículas de minério, o que causa sérios problemas à população, especialmente os relacionados às vias respiratórias.

A empresa de siderurgia CST, instalada há mais de vinte anos no município, ainda não tomou as providências cabíveis para resolver o problema. Uma representação movida por moradores de Vitória, por intermédio do Ministério Público Estadual, resultou em um acordo com a Companhia Vale do Rio Doce para medidas destinadas a conter o movimento de minério em suspensão. Entre as ações, está prevista a instalação de uma cerca flexível (wind fence), projetada especialmente para redirecionar o vento e impedir que ele carregue o pó das pilhas de minério do Porto de Tubarão em direção à capital e outros municípios da RMGV. Na verdade, o wind fence é uma medida paliativa para reduzir emissão de poluentes nas cidades. Abaixo, o desenho esquemático da forma como se comporta o Wind fence na contenção do pó de minério

Portanto, é previsível que a situação se verifique também em Anchieta, uma vez que a localização da siderúrgica se dará no litoral, em que a predominância dos ventos também é na direção nordeste, incidindo diretamente sobre o distrito-sede de Anchieta e sobre as áreas ambientalmente sensíveis. Agravante dessa condição é o fato de que as empresas tendem a não cumprir suas obrigações para mitigação de processos poluentes, apesar das obrigações e critérios previstos na legislação ambiental.

\subsubsection{0 tunismo ameaçado}

Outra possibilidade de impacto refere-se ao desempenho da atividade turística, já tradicional na região. O Plano 2025, ao reconhecer o alto potencial de impacto do Polo na cidade de Anchieta, cria, no plano de metas, o projeto "Rede de Cidades", onde também se inclui o projeto de Desenvolvimento Urbano de Anchieta e Regiões de Impacto. Um dos objetivos do projeto é ordenar o crescimento urbano, compatibilizando-o com os 
RG.62

Loteamento Monte Aghá, que solic itou aprovação junto ao poder público, logo após divulgação da criação do Pólo Industrial de Anchieta. Fonte: IJ SN. 2007.

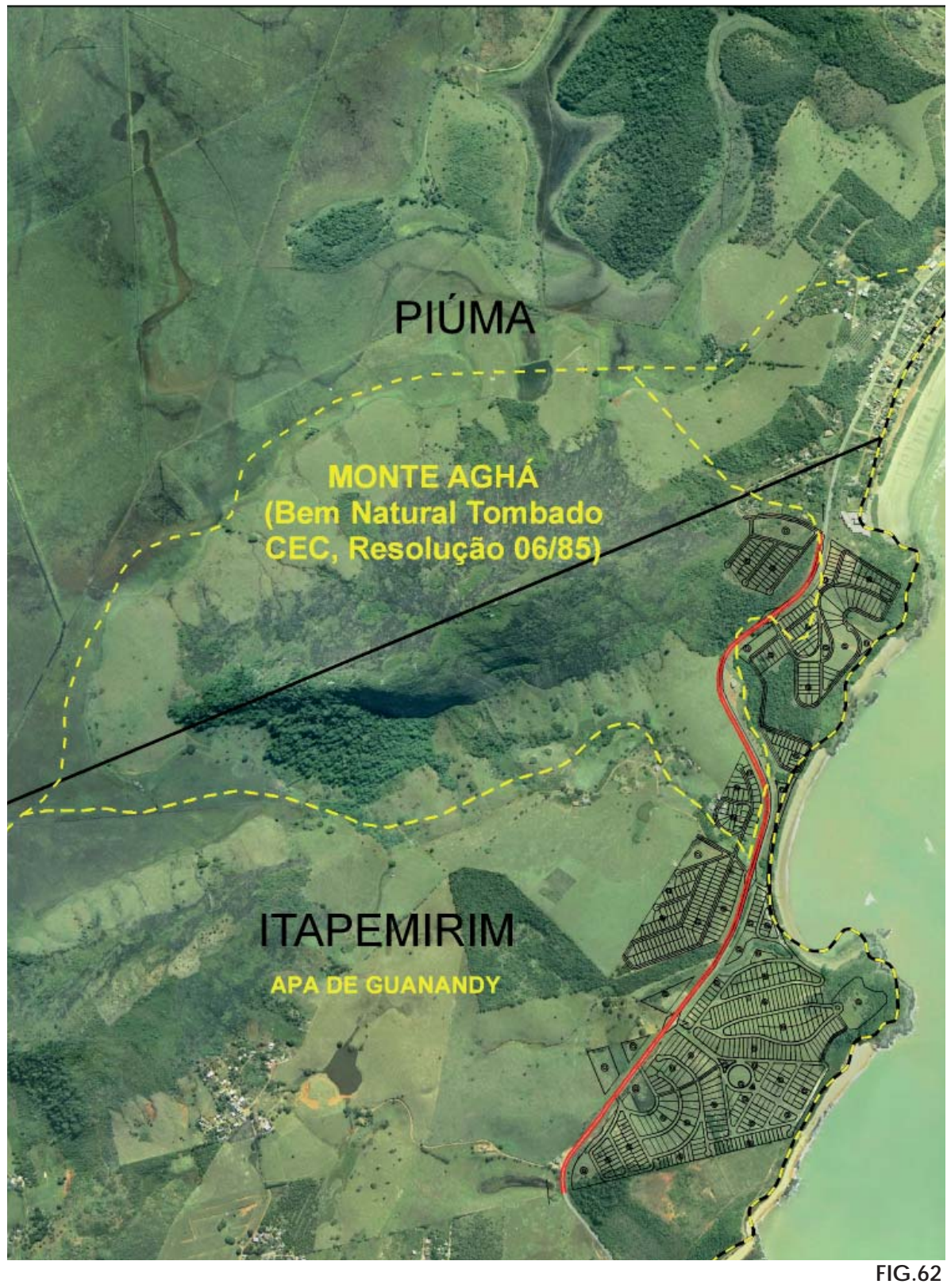

aspectos de preservação histórico-cultural em Anchieta e Alfredo Chaves (Rota dos Imigrantes e Passos de Anchieta) e de conservação dos ambientes de interesse ambiental e de proteção legal.

Na própria pesquisa qualitativa do Plano 2025, há uma preocupação inerente ao destino turístico, observando-se que é uma vocação regional que precisa ser mais bem aproveitada. No item "potencialidades" do ES, o Plano Espírito Santo 2025 faz destaque para o ecoturismo e agroturismo, vislumbrando-se a Microrregião Expandida Sul em 2025 da seguinte forma: "a expansão das atividades de beneficiamento do minério de ferro e do petróleo propiciará o surgimento de uma rede de cidades que crescerá 
de maneira planejada e ordenada e se beneficiará do elevado dinamismo do setor de turismo e da atividade pesqueira" (Plano 2025, 2006). No projeto referente à logística, no item "circuitos turísticos", define-se que a "infra-estrutura viária tem por objetivo criar condições de deslocamentos turísticos em regiões de atrativos naturais do Estado, facilitando o programa de desenvolvimento de programas específicos de turismo, entre outros, a Rota do Mar, do Sol e da Moqueca"120 . Essa foi a primeira rota criada no Espírito Santo para o turismo, voltada para os veranistas, turismo náutico, o turismo religioso, o turismo histórico/cultural e a gastronomia. A culinária capixaba destaca-se pela moqueca e pela torta capixaba, pratos típicos feitos à base de frutos do mar, servidos em panela de barro, artesanato ligado às tradições indígenas. A rota integra os municípios de Serra, Vitória, Vila Velha, Guarapari e Anchieta. Na verdade, não há um percurso rígido com limites delimitados, mas, sim, indicação de roteiros gastronômicos e culturais.

É possível compatibilizar as rotas no litoral sul com a implantação do Polo? Quando se tem uma visão global desses projetos, surgem indagações e preocupações. Como ficará a Rota do Sol e da Moqueca diante de uma rota minero-siderúrgica e logística? Quais as possibilidades e limitações do turismo diante da ampliação da atividade siderúrgica? As ações advindas de um padrão industrial afetarão as belezas naturais e os objetos intrínsecos à paisagem? Quais investimentos turísticos farão sentido? O que predominará? Estas são questões fundamentais, que não podem estar dissociadas das políticas públicas destinadas a dar suporte ao turismo.

Até agora pouca coisa mudou efetivamente, desde que se iniciaram as especulações em torno da efetivação do Polo em Anchieta. Para o presidente da Associação de Desenvolvimento do Turismo do Litoral Sul do Espírito Santo, Antônio Carlos Ferrari, proprietário de um hotel na praia de Iriri, o mercado está parado: "Nossos índices de ocupação não cresceram nem 1\% de um ano para cá e o turismo de negócios ainda não chegou”. Ferrari, que atua na região há mais de 40 anos, não alimenta expectativas: "não tem sentido um executivo ficar em Anchieta se o aeroporto é em Vitória. É mais fácil ficar em Guarapari. O futuro ainda se resume ao turista que

120 Fonte: Governo do Estado do Espírito Santo.< www.es.gov.br/site/turismo/rota_sol_moqueca>. Acesso em outubro 2008. 
sempre veio para cá no verão"121 . Portanto, o fato é que a Região Metropolitana da Grande Vitória continua a exercer grande influência sobre a região do Pólo, por centralizar e oferecer melhores condições em serviços de hotelaria, restaurantes e lazer, atraindo preferencialmente o empresariado local e externo.

Além dessas ressalvas relativas ao turismo, constata-se que as áreas diretamente afetadas e de influência direta do Polo Industrial e de Serviços de Anchieta, ou seja, os municípios de Anchieta, Guarapari e Piúma apresentam uma infraestrutura viária deficitária e incapaz de atender o aumento do fluxo, seja de forma qualitativa seja pela falta de integração entre as redes rodoviárias. O grande entrave atual e com perspectivas de sério agravamento em futuro relativamente próximo é a superposição do tráfego de passagem da rodovia ES 060 com ruas da área central da cidade de Anchieta, trazendo conflitos com a circulação local de veículos, ciclistas e pedestres. Essa situação de conflito do trânsito de passagem se torna ainda mais grave em face da quase inexistência de calçadas e ciclovias/ ciclofaixas. Um aspecto positivo é o fato de a rodovia ES 060 não adentrar os demais núcleos urbanos a ela lindeiros, garantindo, assim, a inexistência de conflitos de tráfego com os trânsitos locais. No entanto, a maior parte dos acessos da ES 060 aos diversos núcleos urbanos não possui interseções adequadas, além de apresentar precariedade em sua pavimentação, com tendência a agravar-se no período de chuvas. Os estudos do sistema viário da AAE (2008) indicam necessidade de melhoria e ampliação da rede para dar suporte ao incremento de atividades turísticas e outras, conforme segue:

- BR 101: Capacidade de tráfego razoável, com problemas de segurança em decorrência da elevada participação de veículos pesados, precariedade na pavimentação em alguns trechos e com um sistema de sinalização/fiscalização deficientes.

- ES 146: Capacidade de tráfego suficiente, mas com restrições na configuração atual do seu pavimento para suportar tráfego pesado.

- ES 060: Capacidade de tráfego insuficiente para demanda adicional em horários de pico, especialmente em períodos de verão. Segmen-

121 FERRARI, Comércio fatura alto. A Gazeta. Vitória. 16 dez 2007. Economia. p.24. Depoimento a Abdo Filho. 
tos do viário principal com nível de serviço próximo ao limite de saturação(finais de semana e feriados). Insegurança em acessos a núcleos urbanos e travessias de áreas centrais.

- Rodovia do Sol (Contorno Guarapari): Capacidade de tráfego suficiente.

Observa-se que o sistema de transporte urbano local apresenta razoável nível de cobertura territorial em Guarapari, porém sem estrutura organizacional/ gerencial adequada. Em Anchieta e Piúma, a demanda é atendida por linhas intermunicipais. Em uma visão regional, a realidade é traduzida por um sistema intermunicipal rodoviário, com funções interurbanas na região, cujas linhas de um modo geral têm origem em Guarapari (e outra parte na RMGV) e destino para outras cidades da região e do seu entorno; porém, elas atendem de forma inadequada às demandas intraurbanas, principalmente as de Anchieta e de Piúma. Uma forma de minorar o problema das limitações do sistema viário é evitar que os custos dos deslocamentos sejam, no futuro, um fator gerador de deseconomias para as cidades da região e para as atividades relacionadas ao turismo nelas estabelecidas. Diante do quadro exposto, as perspectivas de valorização do turismo como alternativa na conciliação com as atividades do Polo, são, no mínimo, remotas.

\subsubsection{O “boom imobiliánio" na região do Polo e reflexos na RMGV}

A transformação da paisagem é também consequência dos processos de especulação e valorização imobiliária, que avançam sobre o litoral. A urbanização da zona costeira brasileira e a expansão do sistema de estradas litorâneas no país transformaram sobremaneira a configuração morfológica do litoral, expandindo os limites das orlas primitivas das cidades litorâneas e destruindo parcelas significativas dos ecossistemas originais. Esse fenômeno foi particularmente intenso no litoral oriental - que se inicia nos arredores do recôncavo baiano e se estende até o sul do Espírito Santo - e no trecho dominado pelas escarpas das Serras da Mantiqueira e do Mar.

Observa-se que uma das características das mudanças que já estão ocor- 
AG.63

Censo Imobiliário mostrando o crescimento do setor imobiliário na RMGV. Fonte: A Gazeta. 2007.

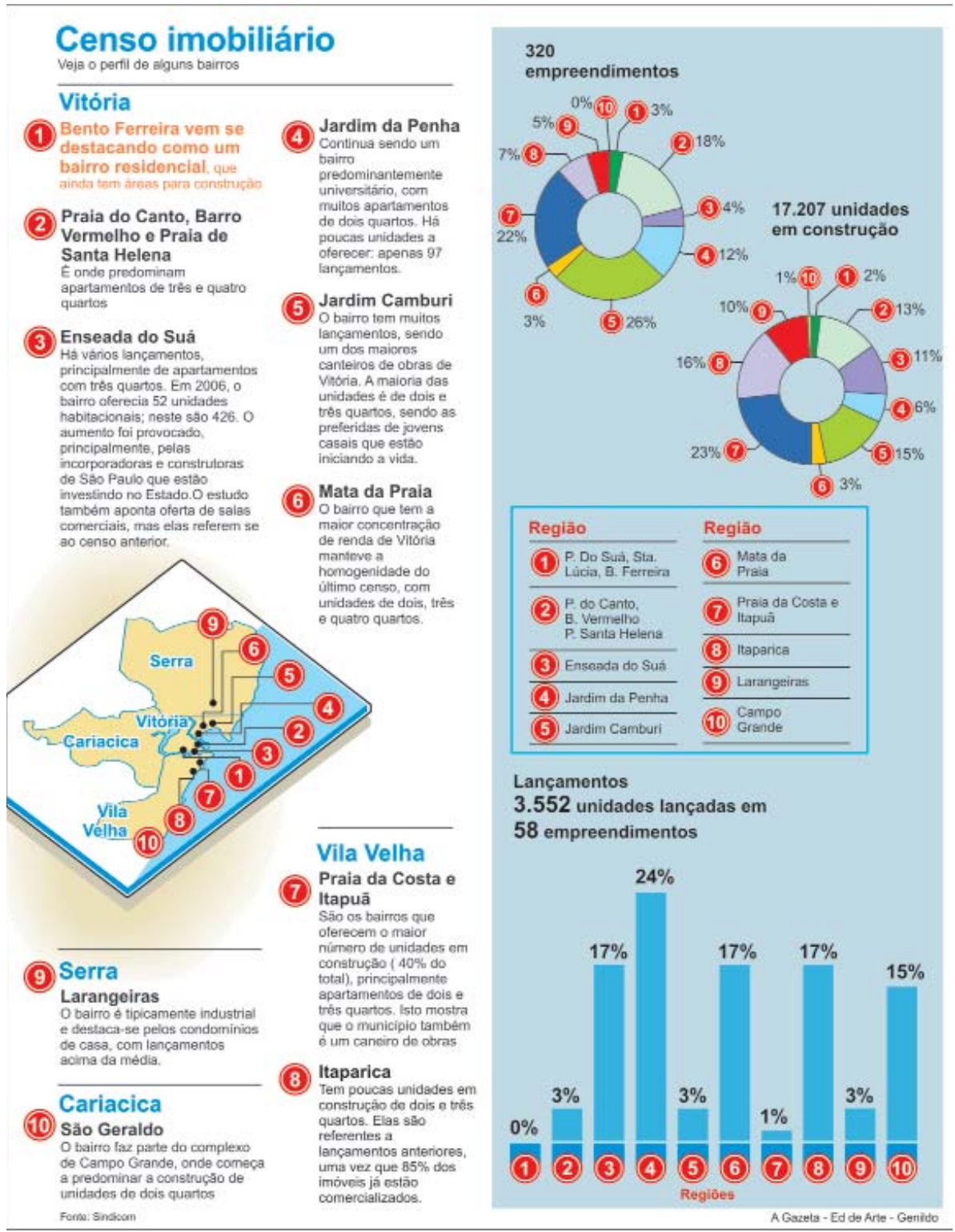

HG.63

rendo ao longo do principal eixo viário - Rodovia do $\mathrm{Sol}^{122}$ - é a formação de áreas de tecido urbano na periferia, em descontinuidade às já existentes nas sedes dos municípios do litoral sul, com múltiplas formas de utilização do território, seja por expansão de grandes loteamentos residenciais, seja pela instalação de comércio e / ou serviços, em pontos isolados.

A oferta de emprego em uma determinada região também interfere na dinâmica do mercado imobiliário, seja por meio da valorização do mercado de locação, especialmente nas áreas onde existe concentração de serviços,

122 A Rodovia do Sol, principal eixo viário litorâneo ao sul de Vitória, faz um percurso que vai desde o município de Vila Velha até Itapemirim. 
seja por meio da oferta de novas áreas residenciais. A proximidade de áreas no entorno do empreendimento alvo do Polo Industrial, por exemplo, pode determinar o valor de comercialização dos lotes, especialmente quando eles complementam a demanda do passivo habitacional. Antigos loteamentos, com anuência prévia, procuram rápida aprovação junto ao poder público, e alguns deles incorporam aos seus projetos áreas de proteção ambiental ou localizam-se no seu entorno imediato. Poderíamos citar como exemplo emblemático dessa situação de conflito, o loteamento Praia de Monte Aghá, cujo projeto incorpora, em seus limites, parte da APA de Guanandy e a APA do Monte Aghá123 ${ }^{123}$ localizados nos municípios de Piúma e Itapemirim, respectivamente (Figura 61). O referido loteamento solicitou regulamentação para aprovação, entretanto esta não foi concedida pelos órgãos competentes.

No ano de 2007, também antecipando-se ao boom imobiliário, um grupo de empresários tentou investir na construção de 1.150 apartamentos em Anchieta. Os imóveis supririam a futura demanda por moradias para funcionários de diferentes níveis da siderúrgica chinesa Baosteel, que, num primeiro momento, era a empresa candidata a se instalar no Polo Industrial de Anchieta.

Em texto de 1994, Françoise Choay ${ }^{124}$ argumenta:

[...] se de um lado há uma tendência à concentração que focaliza os fluxos humanos em direção aos pólos de atuação, que ainda são as metrópoles nacionais ou regionais; mas, por outro lado, as atividades implantam-se nas periferias cada vez mais amplamente irradiadas (...). De outro, uma tendência à dispersão opera uma desconcentração linear ou pontual.

(CHOAY, 1994, apud Reis, 2006)

Quando os processos de concentração e dispersão ocorrem em núcleos urbanos litorâneos, citando aqui alguns exemplos emblemáticos que compõem o litoral sul do Espírito Santo, tais como Vila Velha e Guarapari (RMGV) ou mesmo no litoral entre Anchieta e Piúma, é comum obser-

123 Monte Aghá: Bem Natural Tombado, Resolução 06/85.

124 CHOAY Apud REIS, Nestor Goulart. Notas sobre urbanização dispersa e novas formas de tecido urbano. São Paulo: Via das Artes, 2006. 
varmos a ocorrência dos dois processos simultaneamente, isto é, em geral o centro urbano se transforma por densificação, ao passo que, na periferia, sempre em expansão linear, vai ocorrendo a incorporação de novas áreas, por meio do crescimento por extensão. A ocorrência de assentamentos precários, especialmente nos municípios de Guarapari e Piúma, é um fato que tende a agravar-se com a implantação do Polo Anchieta. O crescimento urbano por extensão caracteriza-se pela incorporação de áreas de uso não urbano pelo uso urbano, direcionadas muitas vezes pelos próprios Planos Diretores Municipais.

Os investimentos previstos no Polo Anchieta e a descoberta de poços de petróleo ao longo da costa já fizeram com que também o mercado imobiliário da Região Metropolitana da Grande Vitória (RMGV) sofresse acelerado aquecimento na comercialização dos imóveis e, sobretudo, uma alta dos preços nas vendas e nos aluguéis, verificados especialmente nos anos de 2007 e 2008. Os números do Censo Imobiliário - estudo do Sindicato das Empresas de Construção Civil do Estado (Sindicon-ES) também provam que o boom imobiliário se mostrou, nesse período, em curva ascendente. Somente no primeiro semestre de 2007, a valorização foi de $13 \%$, e, no acumulado, de $25 \%$. Em comparação ao último censo imobiliário, divulgado em dezembro de 2006, o perfil predominante dos compradores continua o mesmo: pessoas de classe média e média alta, que optam por apartamentos de dois e três quartos - imóveis que representam $72 \%$ das unidades em construção.

$\mathrm{Na}$ perspectiva de crescimento econômico, os empresários locais estão se unindo e criando parcerias com várias construtoras e imobiliárias de fora do estado, especialmente oriundas de São Paulo e Rio de Janeiro, tais como, Cyrela, Morar, Incortel, Lopes. Essas empresas estão se instalando, construindo e lançando uma série de empreendimentos na RMGV. Os maiores lançamentos destinam-se aos bairros Enseada do Suá, Jardim Camburi, Jardim da Penha, localizados em Vitória, e aqueles situados no município da Serra, como Laranjeiras, e no município de Vila Velha, como Itaparica.

Observa-se também que a mídia desempenha papel importante na divulgação do Polo Anchieta e demais projetos vinculados ao Plano 2025, for- 
talecendo as expectativas de valorização do setor imobiliário, assim como induzindo, de certa forma, a ocupação privada em determinados trechos da região litorânea. Diariamente, no decorrer de todo o ano de 2007 e de 2008, os principais jornais de circulação do estado tiveram como principais manchetes a questão dos grandes projetos, fazendo paralelamente uma correlação com o crescimento do mercado imobiliário e apontando as tendências de expansão, especialmente no "Caderno Economia" e nos suplementos semanais "Imóveis." 


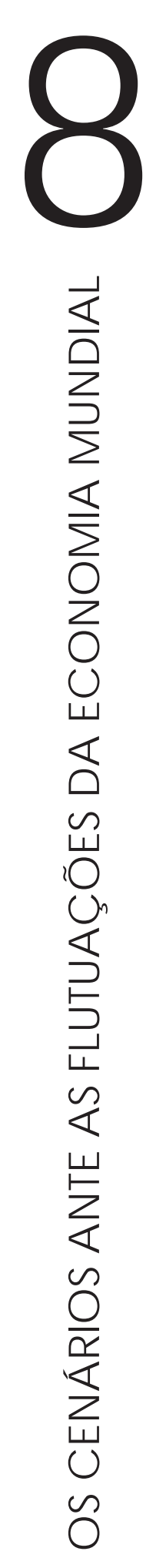

É essa ação que transforma a simples possibilidade do virtual em realidade virtual, ou seja, virtual e real misturam-se e superpõem-se. "A noção e a realidade da rede provocam um sentimento de ambigüidade, cada vez que não consideramos o seu caráter definitivo, que é ser um híbrido, um misto" [Santos, 1996, p.222]. É essa ação que incorpora ao virtual sua dimensão real que é local e global ao mesmo tempo, porque é sempre social.

Ferrara (2000) 
266| CAṔ́TULO 8 


\section{OS CENÁRIOS ANTE AS FLUTUAÇÕES DA ECONOMIA MUNDIAL}

Conforme atestam os próprios estudos do Plano 2025, o planejamento estratégico de longo prazo exibe fragilidades que representam gargalos estruturais ou vulnerabilidades ao crescimento sustentado. Por isso, a visão de futuro deve estar balizada por estudos prospectivos que contemplem os condicionantes do cenário atual e trajetórias alternativas possíveis para o estado. Diante das incertezas relativas ao ambiente externo (mundo, Brasil e entorno regional) e como resultado da combinação de hipóteses, o Plano 2025 trabalha com três cenários hipotéticos que podem vir a se consolidar ou não, conforme sejam as variáveis que se estruturam no âmbito mundial ${ }^{1}$ :

- CENÁRIO A - Desenvolvimento Sustentado: Aproveita o contexto externo favorável à época da sua formulação, considerando que os principais atores políticos, econômicos e sociais capixabas vão investir fortemente na melhoria de suas instituições, viabilizando um salto qualitativo para um novo modelo de desenvolvimento sintonizado com a chamada sociedade do conhecimento e da informação que se desenvolve em escala mundial.

- CENÁRIO B - Crescimento Excludente: Os atores capixabas não vão conseguir aproveitar as oportunidades oferecidas por um mundo em expansão econômica, pelo Brasil em crescimento e por um setor de petróleo que experimenta o excelente desempenho no Estado. Assim, o Espírito Santo não se mostrará capaz de transformar substancialmente o padrão de vida da população.

- CENÁRIO C - Estagnação e retrocesso: A inexistência de uma visão de futuro compartilhada, a fragilidade das instituições públicas e privadas e as acentuadas descontinuidades e deficiências da gestão pública podem impedir o bom aproveitamento dos recursos não renováveis e inibir a atração de novos investimentos produtivos, com reflexos negativos na formação do capital humano e na diversificação e adensamento da economia. Pobreza, desigualdade e violência c poderão continuar a fazer parte da vida cotidiana dos capixabas. 
A globalização passa por um momento que sugere novas reflexões. Desse modo, há que se pensar nas possibilidades do Plano 2025 e, consequentemente, nas possibilidades de sucesso ou insucesso na implantação do Polo Anchieta. Há, portanto, que se trabalhar estratégias alternativas diante de cenários extremamente dependentes de situações externas, já que grande parte do modelo econômico está apoiado nas macroestruturas vinculadas às redes técnicas globais. Esta é a grande vulnerabilidade à qual está atrelada a concepção do Plano 2025.

Segundo Marx, "tudo está impregnado de seu contrário", onde o progresso e o avanço do capitalismo só são possíveis por meio da destruição e da desigualdade. Os perigos dessa contradição permanente no capitalismo afligem a aldeia global, mas, ao mesmo tempo em que aciona o movimento em direção ao inesperado, a uma expansão interminável. A instabilidade do sistema é uma das premissas básicas em que se funda o capitalismo moderno. Para uma rápida amostragem dessa condição, basta nos reportarmos a um fenômeno recente: a crise financeira mundial que abalou o mercado internacional. Diante de uma crise mundial ${ }^{126}$ como a revelada em 2008 e da instabilidade do quadro econômico, países como o Brasil, com uma elevada participação nas exportações por commodities ficam muito suscetíveis às oscilações do mercado externo.

Podemos até relevar a condição de que uma sociedade muito desigual pode crescer bastante, como aconteceu com o Brasil até os anos 1980, mas

126 Trata-se da crise financeira desencadeada a partir da quebra de instituições de crédito dos Estados Unidos, que concediam empréstimos hipotecários de alto risco (em inglês: subprime loan ou subprime mortgage), arrastando vários bancos para uma situação de insolvência e repercutindo fortemente sobre as bolsas de valores de todo o mundo. A crise foi revelada ao público a partir de fevereiro de 2007, como uma crise financeira, no coração do sistema Uma crise grave - e segundo muitos economistas, a mais grave desde 1929, com possibilidades, portanto, de tra nsformar-se em crise sistêmica, entendida como uma interrupção da cadeia de pagamentos da economia global -, que tenderia a atingir generalizadamente todos os setores econômicos. A crise (2007/2008) foi precipitada por uma bolha no mercado de residências e, em certos aspectos, é muito similar às crises que ocorreram desde a Segunda Guerra Mundial, em intervalos de quatro a 10 anos. George Soros faz uma importante distinção entre essa crise e as anteriores, considerando a crise atual como o clímax de uma superexpansão (super-boom) que ocorreu nos últimos 60 anos. Segundo Soros, os processos de expansão-contração (boom-bust) giram ao redor do crédito e envolvem uma concepção erronea, que consiste na incapacidade de se reconhecer a conexão circular reflexiva entre o desejo de emprestar e o valor das garantias colaterais. Crédito fácil cria uma demanda que aumenta o valor das propriedades, o que por sua vez aumenta o valor do crédito disponível para financiá-las. As bolhas começam quando as pessoas passam a comprar casas na expectativa de que sua valorização permitirá a elas refinanciar suas hipotecas, com lucros. Isso foi o que aconteceu nessa última crise. SOROS, George. The worst market crisis in 60 years. London: Financial Times. 22 jan 2008. Disponível em : <http:// wikipedia.org/wiki/Crise_econômica 2008-2009>-Acesso em jan. 2009 
esses períodos de crescimento oscilam por causa da instabilidade política e do fato de que a riqueza não é distribuída por toda a sociedade global. A análise desenvolvida pelo economista Francis Fukuyama ${ }^{127}$ para a crise é, segundo ele, resultante de um movimento que há 30 anos prega a nãointervenção no mercado, mas que hoje, exige mais intervenção gerencial do Estado nas políticas e nas idéias.

Diante da crise financeira generalizada que atingiu os países centrais, os presidentes, Barack Obama, dos Estados Unidos, e Nicolas Sarkozy, da França, adotaram medidas protecionistas para favorecer a produção interna, as exportações e manter a taxa de empregos; os bancos obedecem a diretivas para aumentar seus empréstimos, retirando-se, se preciso for, dos mercados estrangeiros. As medidas protecionistas no setor bancário são mais fortes que no setor industrial. Em reação à crise econômica, governos reveem liberalismo e endurecem fronteiras nacionais: protecionismo, tensão social, xenofobia irrompem na globalização.

Considerando que as crises são fenômenos inerentes ao processo capitalista de produção e que o modelo da economia do Espírito Santo está voltado preferencialmente para as exportações de commodities, há de se convir que o resultado dessa interação aponta para fragilidades no percurso de um plano estratégico que se apoia na conexão com as redes globais.

O principal produto exportado pelo Espírito Santo é o minério de ferro. Um bom indicador para se avaliarem os efeitos da crise sobre a produção industrial nas diferentes regiões do país é a taxa de variação da média móvel trimestral - a qual considera a média dos últimos três meses e a compara com a média do mesmo período doze meses atrás -, na medida em que ela ameniza os possíveis efeitos calendário e de eventos específicos ocorridos em determinado mês. Observa-se que o nível geral de produção industrial no Brasil foi, em abril de 2009, 13,7\% menor do que o de igual período de 2008. Segundo dados divulgados pelo IBGE, na passagem de março para abril de 2009, justamente no período ápice do reflexo da crise no Brasil. Todas as localidades eminentemente industriais pesquisadas

127 FUKUYAMA, F. Nações Fora do Lugar. Folha de São Paulo, São Paulo, 15 fev.2009. Caderno Mais, p.5. Francis Fukuyama é professor da Universidade Johns Hopkins, economista e filósofo norte-americano de origem japonesa, autor do livro "Falling Behind - Explaining the Development Gap Between Latin America and the United States" em entrevista para a Folha de São Paulo. 
apresentaram recuos, se verificarmos a comparação mensal (mês/mesmo mês do ano anterior).

Vale ressaltar que, em todas as análises comparativas, o estado do Espírito Santo registrou o pior desempenho. Em relação a abril de 2008, houve recuo de $26,7 \%$, influenciado, principalmente, pela indústria extrativa $(-44,2 \%)$ e pelo setor de metalurgia básica $(-38,0 \%)$. No acumulado entre janeiro e abril de 2009 , em face do mesmo período do ano anterior, a indústria no estado do Espírito Santo apresentou queda de 30,4\%, originada da indústria extrativa $(-51,9 \%)$ e do ramo de metalurgia básica $(-40,6 \%)$. As maiores pressões negativas refletem os efeitos da retração do comércio mundial, conforme mostra o gráfico:

Ao incorporar em sua formulação a dimensão territorial, o Plano Espírito Santo 2025 remete, necessariamente, a diversas dinâmicas abrangentes e articuladas, correndo o risco, por este motivo, de ser entendido como um arcabouço capaz de resolver todos os problemas do território. Entretanto,

\section{Gráfico 2}

Produção industrial

\section{Produção Industrial - Abril/2009}

Variaçăo \% com Relaçăo ao Mesmo Mês do Ano Anterior

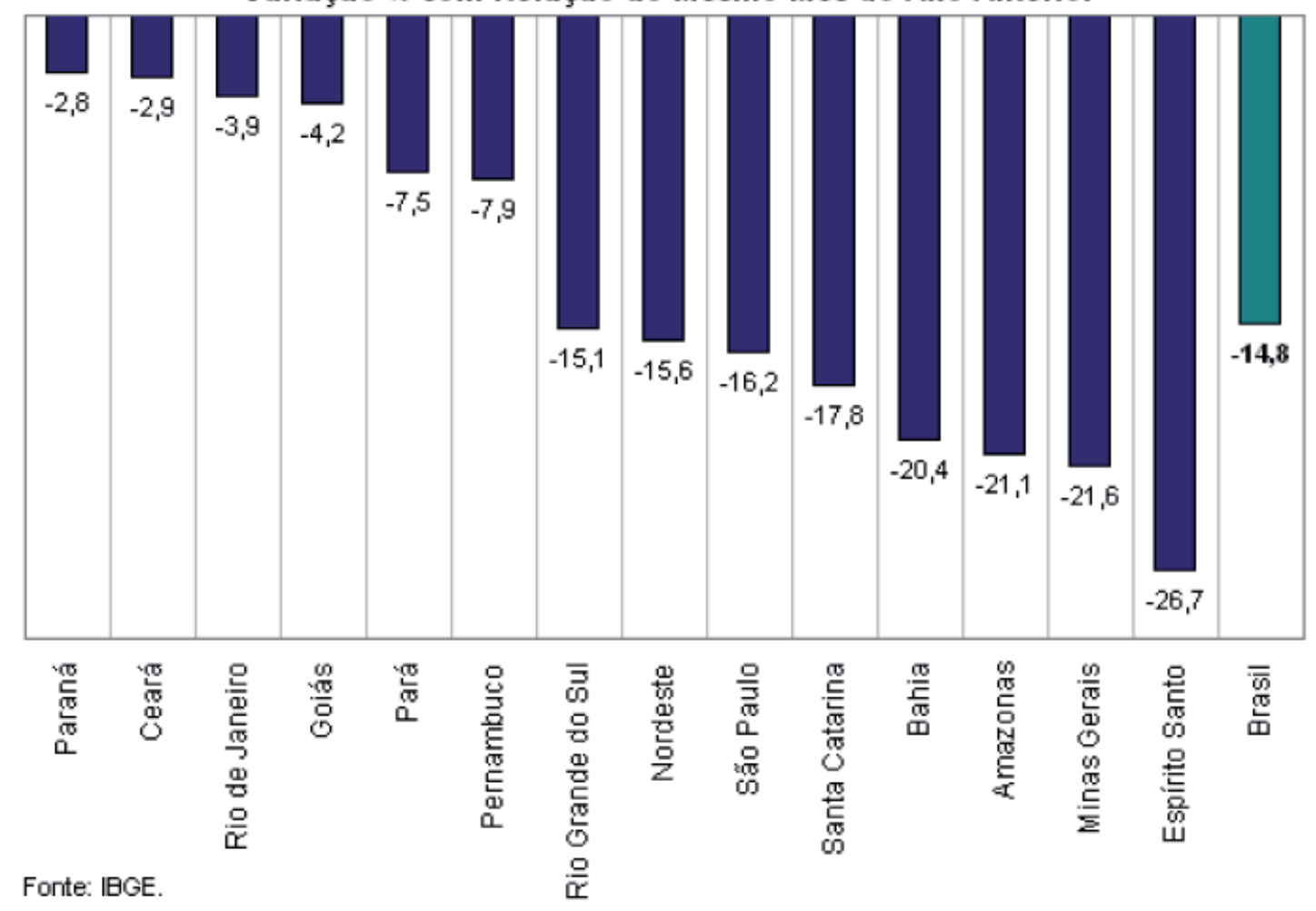


exatamente na euforia e no otimismo em que foram consolidadas as bases para a construção do Plano é que reside o perigo: a convicção de que o crescimento econômico já está contratado e que nenhum cenário adverso pode vir a modificar tal tendência. O risco é ainda maior quando a dimensão econômica fica dissociada das demais, atribuindo-se ao governo e ao cenário externo a totalidade das expectativas por mudança.

\subsection{Os resultados da AAE e a saída da Baosteel}

O Comitê da Bacia Hidrográfica do Rio Benevente ${ }^{128}$ rejeitou a construção da siderúrgica Baosteel, em reunião ordinária do "Parlamento das Águas”, ocorrida em Anchieta, dia 18 de junho de 2008, após apresentação da AAE - Avaliação Ambiental Estratégica. Na reunião, os membros do Comitê se mostraram totalmente contrários à localização do Polo Industrial e de Serviço de Anchieta, situado às margens do Rio Benevente. As razões relatadas foram a insuficiência dos recursos hídricos no atendimento à demanda e o provável comprometimento de toda a bacia hidrográfica. A CESAN (concessionária de água) já havia atestado a não capacidade de suporte e de atendimento às grandes empresas pela bacia do Rio Benevente, o que já inviabiliza o discurso de sustentabilidade do empreendimento. E, sem água, nenhuma siderúrgica consegue produzir.

A Baosteel é a principal siderúrgica da China, país que multiplicou sua demanda de aço e de outros metais nos últimos anos. A princípio, o Governo do Estado apoiou a vinda da Baosteel, produtora e maior exportadora mundial de minério de ferro, considerando que a Vale se associaria à empresa chinesa e teria como uma das razões principais o barateamento dos fretes de minério de ferro para a China, atualmente acima da média. A siderúrgica teria seu próprio sistema de geração de energia e produziria excedente.

A negociação com o grupo chinês começou há dois anos aproximadamente. A ideia inicial de colocar uma siderúrgica em Ubu foi do Governo do estado do Espírito Santo. O anúncio oficial da parceria da Boasteel com a Vale foi feito em outubro de 2007. A partir de então, o governo enviou

128 O Comitê do Rio Benevente, tem, entre as competências, a de "arbitrar os conflitos relacionados aos Recursos Hídricos da bacia, de acordo com a lei federal 9.433. 
meia dúzia de missões oficiais à China, que incluíam desde o governador Paulo Hartung até os técnicos do Instituto Estadual do Meio Ambiente (IEMA), passando por representantes das Federações da Indústria, do Comércio, dos Transportes e até da Agricultura. Colaboradores da Baosteel estimam que a empresa e a sua parceira brasileira já haviam investido no Espírito Santo algo em torno de R $\$ 30$ milhões em estudos, projetos, análises e contratações de todo gênero. $\mathrm{Na}$ época do cancelamento, a empresa Baosteel já tinha um andar inteiro em funcionamento num bairro nobre de Vitória. O propósito era construir em Anchieta a Companhia Siderúrgica Vitória (CSV), uma mega usina com capacidade para produzir 5 milhões de toneladas anuais (2012), podendo chegar a produção, num futuro próximo (2018), a quatro unidades, totalizando 20 milhões de toneladas anuais.

Ao final de 2008, o impasse gerado em torno da instalação da instalação da empresa siderúrgica Baosteel em parceria com a VALE teve um desfecho final desfavorável à implantação da usina. O Governo do Estado divulgou os resultados da AAE e optou por não permitir a instalação da siderúrgica chinesa Baosteel em Anchieta. Com o objetivo de monitorar as questões que envolvem o Polo Industrial e avaliar os possíveis impactos, o governo estadual solicitou a Avaliação Ambiental Estratégica (AAE), instrumento previsto na legislação ambiental. O AAE é reconhecido como o instrumento de política ambiental adequado para promover a articulação das várias dimensões de uma dada política, um plano ou um programa de desenvolvimento, permitindo que se explicitem com clareza seus objetivos e as questões ambientais relacionadas à sua implementação. $O$ instrumento serve, assim, para orientar os agentes envolvidos no processo e indicar os caminhos para sua viabilização econômica, social e ambiental, facilitando ainda a avaliação de impactos cumulativos porventura resultantes das diversas ações a serem desenvolvidas.

O AAE foi coordenado pelo movimento empresarial "ES em Ação", que contratou três empresas de consultoria - Cepemar, Futura e Sereng -, com finalidade de verificar critérios e procedimentos estabelecidos pelo Termo de Referência do Governo do Estado do Espírito Santo na criação do Polo Industrial e de Serviços e de formalizar dados para fins de monitoramento pelo Governo do Estado. Foram definidos os seguintes 
municípios como área de influência do Polo Industrial e de Serviços de Anchieta: a) direta - Anchieta, Piúma e Guarapari; b) indireta - outros municípios da região no entorno do Pólo, incluindo aqueles situados na bacia do Rio Benevente.

Os estudos contemplados para a elaboração da AAE caracterizaram-se pelo levantamento e análise dos seguintes aspectos: recursos ambientais e suas interações, incluindo questões básicas como o uso da água e a capacidade de atendimento à demanda da Bacia Hidrográfica do Rio Benevente; caracterização socioeconômica e análise produtiva e ocupacional da região, assim como avaliação dos sítios e monumentos históricos; análise da infraestrutura urbana e aspectos relativos ao uso e ocupação do solo; identificação de cenários de referência e desenvolvimento; avaliação dos potenciais impactos; por fim, a identificação de planos e programas a serem desenvolvidos. Para tanto, as análises seguiram o seguinte plano de avaliação (ES em AÇÃO, AAE, 2008, p. 208):

D1 - Demanda Atual - Avaliação das limitações, deficiências dos sistemas, principais problemas, capacidade para gerir as demandas - Análise de Contexto.

D2 - Previsão de Impactos - Avaliação da disponibilidade de recursos e ou serviços existentes em virtude de um aumento de demandas, avaliação desdobramentos socioeconômicos e ambientais iminentes - Impactos Previstos.

D3 - Provável Aprofundamento - Verificação da extrapolação da capacidade de gerência das demandas, indisponibilidade de recursos e ou serviços, em virtude da instalação do Polo - Previsão de aprofundamento dos Impactos.

Para fins de análise dos resultados, interessa, aqui, apresentar os fatores críticos (FCDs), observados na AAE, que ajudaram na decisão do governador em não permitir a instalação, num primeiro momento, da referida siderúrgica. Dentre os 43 fatores relevantes considerados nas análises, 14 (catorze) foram considerados com alto índice de criticidade, atingindo o nível 5, devendo impactar sobremaneira a região, se implantado o Polo, conforme segue, por ordem decrescente do valor percentual do índice: 
1. incremento na demanda futura de água com a implantação do Polo, o crescimento populacional e da área de irrigação, no limite da disponibilidade hídrica do Rio Benevente (166,67);

2. alteração na concentração de PTS e PM10 (166,67\%);

3. necessidade de qualificação dos trabalhadores para fazer frente às perspectivas de geração de postos de trabalho (166,67\%);

4. demanda por uma gestão mais eficiente da segurança publica, com aporte adicional de infraestrutura, equipamentos e pessoal (154,66\%);

5. limitações do sistema viário e do transporte coletivo atual para atender às demandas decorrentes da implantação do Pólo (148,67\%);

6. necessidade de supressão da vegetação nativa remanescente $(148,67 \%)$;

7. incremento de população flutuante e impacto sobre os serviços públicos e as questões sociais $(148,66 \%)$;

8. necessidade de incremento na oferta de serviços de saúde para atendimento das novas demandas (146,67\%);

9. baixa densidade institucional das prefeituras da região do Pólo para exercer as atividades de regulação, de controle e de promoção do desenvolvimento local (136,67\%);

10. presença da comunidade de pescadores com forte vinculação com as atividades econômicas (130,67\%);

11. baixa capacidade de absorção dos impactos positivos do efeito produção de riqueza adicional (PIB), no município de Anchieta (126,66\%);

12. maior pressão sobre o uso e ocupação do solo urbano $(116,67 \%)$;

13. necessidade de mapeamento e ocupação dos sítios arqueológicos de Anchieta (106,67\%);

14. aplicabilidade e atualidade dos Instrumentos (106,67\%).

Os três piores resultados referem-se à problemática ambiental, tais como a incapacidade de resposta ao aumento considerável da demanda por água e a elevada alteração na concentração de poluentes, seguida pela necessidade de qualificação da mão de obra local para fazer frente aos novos postos de trabalho. A AAE apresenta, para cada fator crítico, uma avaliação com respectiva elaboração de um PPP - Planos, Programas e Projetos -, que visa minimizar os impactos negativos do Polo e gerir o aumento das demandas. Entre as atribuições da AAE, está o monitoramento e acompanhamento dos PPPs, por meio da constituição de um Conselho representado por instituições governamentais (COPLAM, ADERES e prefeituras municipais), 
além do Fórum de Ubu e Comitê da Bacia do Rio Benevente.

Sabe-se que as pesquisas desenvolvidas para realização de diagnósticos, prognósticos e de avaliação ambiental foram terceirizadas, e sua responsabilidade coube às mesmas empresas que, tradicionalmente, já atuam no setor de prestação de serviços às instituições públicas, presumindo-se uma parceria. Observa-se que as parcerias, sempre renovadas, caracterizam-se por um continuísmo que compromete seus resultados, especialmente de forma qualitativa. Agrava-se também o papel de interlocutor "passivo", adotado pela ADERES ${ }^{129}$, firmando uma postura um tanto quanto imparcial na condução dos debates e da postura técnica em face da dinâmica acelerada que envolve o Polo. Ao coordenar o processo, a ADERES estabeleceu reuniões quinzenais para apresentação de dados e discussão dos temas relativos à questão, restritas apenas a alguns técnicos das instituições e secretarias de Governo do Estado.

Em paralelo a essas reuniões de cunho técnico e governamental, o Fórum de Ubu foi criado com o objetivo de se tornar o espaço de discussão das questões relativas ao Polo industrial de Anchieta mais participativo, e sua coordenação coube ao Ministério Público da Microrregião Sul. A criação do Fórum gerou grandes expectativas, e as entidades civis esperavam que o desejado diálogo com as autoridades tivesse início. As apresentações realizadas em Anchieta para tratar da Avaliação Ambiental Estratégica do Polo ocuparam grande parte do tempo da sociedade civil interessada em discutir questões importantes, mas as respostas das autoridades às questões colocadas pelas entidades foram sutilmente desviadas para se tornarem uma clara apologia à instalação da Baosteel.

O tradicional argumento usado pelo poder público para justificar a ausência da sociedade civil nas discussões técnicas é o da incapacidade da população comum em participar de decisões sobre assuntos de interesse coletivo que exigem certo conhecimento técnico. Na realidade, mais do que presumir a não viabilidade da participação popular direta nestes fóruns, os defensores do sistema representativo costumam ir mais longe,

129 ADERES - Agência de Desenvolvimento em Rede do Espírito Santo - é uma autarquia que tem como principal compromisso a articulação e a viabilização de parcerias e condições para implementação de projetos especiais ou prioritários do Governo do Estado. A ADERES tem como presidente Cristina Vellozo Santos. 
argumentando que essa participação não seria desejável, sob os ângulos da eficácia e da eficiência, uma vez que, no Executivo, os técnicos seriam os únicos capazes de deliberar racionalmente e com isenção a respeito da administração pública.

Não se assume que o baixo nível de informação da maioria da população é fruto de uma sociedade sobre a qual se encontra cristalizado e sancionado um acesso brutalmente desigual à educação e à informação. É necessário atentar ao fato de que não se está defendendo que o planejamento dispense a atuação de técnicos, que têm um papel importante na identificação de diferentes aspectos da realidade; entretanto, acredita-se que a "leitura técnica" deve apoiar e complementar uma "leitura participativa", conforme argumenta Souza (2006). E mais, que esta leitura técnica deva ser compartilhada e debatida pelos diferentes agentes sociais sem que a tomem como uma verdade absoluta.

É que esses técnicos/pesquisadores, e não os cidadãos, devam se arrogar o privilégio de definirem o conteúdo dos fins, das metas. Sua função seria mais adequadamente a de um consultor popular, capaz de aconselhar, sobre a base de seu treinamento profissional para coletar, manusear e integrar dados volumosos e de natureza variada e para refletir combinando diversas escalas espaciais e temporais, uma coletividade formada, tanto quanto possível (ao menos é essa a meta), por cidadãos livres. Cidadãos livres que, para serem de fato livres, não podem alienar seu direito de serem os agentes responsáveis pela deliberação e aprovação dos conteúdos essenciais do planejamento e da gestão de seus espaços e de suas vidas (SOUZA, 2006, pg.14).

O Fórum de Ubu afirma ainda que algumas reuniões foram também utilizadas para que o Iema (Instituto Estadual do Meio Ambiente) formalizasse os convites a alguns líderes e autoridades para conhecerem a empresa Baosteel na China. Como se o fato de isso acontecer em espaço legalmente e democraticamente constituído pudesse afastar, de forma categórica, qualquer suspeita de tentativa de cooptação. Nesse contexto, quando as ações são cunhadas com uma visão eminentemente técnica, alguns valores são realçados em detrimento de outros, inviabilizando a possibilidade de visões diferenciadas serem compartilhadas e debatidas. Em geral, as propostas são tecnicamente bem construídas; porém, frequentemente, elas padecem de um vício de origem por estarem descoladas da realidade coti- 
diana das pessoas diretamente envolvidas.

A ambientalista Ilda de Freitas, presidente do Programa de Apoio e Interação Ambiental (Progaia), relatando as discussões do Fórum das Entidades Civis Organizadas do Litoral Sul do Espírito Santo, compostas por 20 entidades fundadoras, afirma que a agregação em torno do interesse comum é o instrumento mais importante para enfrentar o que ela considera como a luta mais desigual de todas aquelas das quais participou. A ambientalista afirma que não seria possível descrever o nível de preocupação da população local e de muitos moradores que integram a RMGV diante do que está ocorrendo no Espírito Santo, nem a densidade e importância das questões levantadas, conforme relato:

\begin{abstract}
David contra Golias é fichinha comparado com o que foi minuciosamente preparado pelas multinacionais e poder público durante anos para subjugar a população capixaba e transformar nosso Estado, na prática, em área privatizada das multinacionais. Na teoria, tudo parece estar em harmonia com as leis, com a democracia, com a constituição e até com as duras vitórias conquistadas, ao longo de séculos, para assegurar aos seres humanos um mínimo de Justiça, de igualdade de direitos, de garantia de qualidade de vida para a atual e futuras gerações.
\end{abstract}

Ilda de Freitas $(2008)^{130}$

A Baosteel e a Vale chegaram a contratar a empresa de consultoria Agência 21, do Rio de Janeiro, para fazer um trabalho junto aos líderes locais da sociedade civil de Anchieta. Ilda de Freitas relata que os funcionários da Agência 21 só quiseram falar com os líderes do movimento ambientalista em reuniões fechadas, em base desigual de participação: seis funcionários da empresa para apenas um participante do movimento ambientalista, o que gerava situações desconfortáveis e constrangedoras. No entendimento de Ilda, a empresa Cepemar, responsável pela análise ambiental da AAE, já havia constatado que todas as lideranças foram contra a instalação da siderúrgica CSV (Baosteel-Vale) e que, em virtude disso, contratou a empresa carioca para "tentar, com manipulação, fazer com que as entidades fossem a favor da instalação". A ambientalista descreve esse episódio em seu blog

130 Presidente do PROGAIA - Programa de Apoio e Interação Ambiental.Coordenadora do Fórum de Entidades Civis Organizadas do Litoral Sul do ES. Depoimento no blog Pousada das Bromélias e do Progaia. 2008. 
divulgado na Internet:

O grupo de consultores responsável pela intermediação com o Fórum das Entidades Civis é composto por jovens, todos bem educados, bem vestidos e simpáticos. Cada um domina um assunto. Dizem que estão apenas abrindo o diálogo da Baosteel-Vale com a sociedade civil. Os líderes da sociedade civil são convidados a responder um questionário para o qual não tiveram tempo de se preparar. O que a estratégia reúne: efeito surpresa, grupo preparado contra uma pessoa despreparada e o próprio questionário, que é executado de tal forma que pode induzir alguns a contradições. Isto sem contar que das respostas do questionário poderia ser extraído apenas o que interessa às empresas. Outro ponto importante é que a abordagem do grupo enfatiza o diálogo com a sociedade, desenvolvimento sustentável e o projeto Vale.

Ilda de Freitas

Após todo o processo de negociação entre as partes interessadas, mais precisamente no dia 28 de novembro de 2008, o Governo do Estado anuncia publicamente o cancelamento do projeto da siderúrgica CSV (parceria Baosteel - VALE). A notícia, veiculada nos jornais de todo o estado, anunciavam o veto à instalação da siderúrgica chinesa: a incapacidade de suporte da rede hídrica, o aumento significativo relativo à emissão de partículas poluentes e os problemas sociais gerados pela falta de infraestrutura do município foram os principais argumentos usados na justificativa dos motivos que levaram o governo a tal decisão.

Para os munícipes de Anchieta, já era óbvio que a siderúrgica traria, na sua esteira, danos irremediáveis para o meio ambiente, com a degradação das suas belezas naturais, assim como o agravamento da poluição atmosférica, uma vez que os índices de poluentes já eram superiores ao tolerado. Também era evidente que o aporte súbito de milhares de pessoas para as frentes de trabalho nessa atividade iria gerar um impacto social de grande envergadura, em um município com uma infraestrutura de porte reduzido, que veria sua população quase dobrar em tempo recorde.

Ainda não ficaram muito claras as razões que levaram o governo estadual a barrar a implantação da usina siderúrgica chinesa, de forma inesperada. 
PG. 64

A notícia veiculada na mídia: o govemo estadual veta a Baosteel alegando problemas ambienta is com base no resultado da AAE. Fonte: A Gazeta, Vitória, 28 nov. 2008

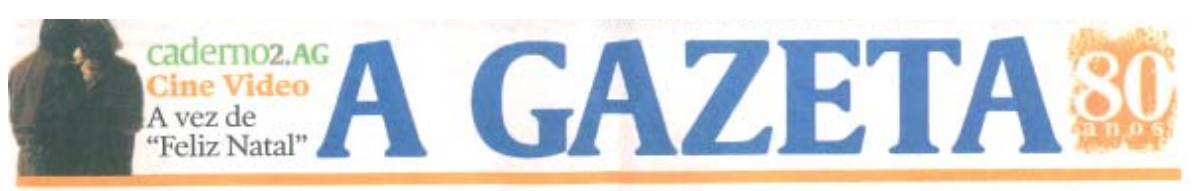

Gigante do aço. Indústria deveria iniciar operação em 2012 e produzir 5 milhōes de toneladas por ano Sobra pó, falta água. E pólo de Anchieta fica sem siderúrgica

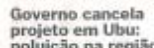
polucicio na regiso a atinge $91 \%$ do
imite permitido
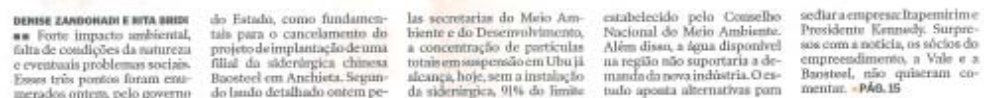

RG. 64

É importante ressaltar que a decisão do Governo do Estado em vetar a instalação ocorreu concomitante à deflagração da crise financeira mundial (2008), que impactou os mercados de diversos países.

Em entrevista, o vice-governador, Ricardo Ferraço, assegurou que a decisão tomada foi exclusivamente com base na Avaliação Ambiental Estratégica (AAE). Entretanto, tal argumentação não convenceu a sociedade, de modo geral. $\mathrm{Na}$ ocasião, a decisão não pareceu estritamente técnica. Mesmo porque, ainda hoje (2009), assentada a poeira da crise mundial, a Vale realiza negociações com o Governo do Estado em torno de nova siderúrgica. Dessa vez, só que com outro nome: Companhia Siderúrgica de Ubu (CSU). Em face da crise mundial que eclodiu no segundo semestre de 2008, buscar explicações plausíveis para o discurso repentino adotado pelo Estado em prol da causa ambiental é um pouco temerário, diante do discurso até então propagado pelo governo estadual - o do progresso tecnológico e desenvolvimento econômico do estado.

Alguns contra-argumentos podem ser elencados para a súbita mudança de estratégia. Um deles é que a versão oficial do governo é simpática ao movimento ambientalista e se compatibiliza com a estratégia de valoração da imagem pelo marketing político. Outro contra-argumento é que o governo não tomou essa decisão meramente por questões ambientais, pois o apoio do governo era evidente até quando eclodiu a crise mundial, que poderia comprometer seriamente os investimentos em siderurgia, cujo mercado é estritamente dependente das redes globais.

Um questão se impõe: Se o governo do estado tem mesmo tanta preocupação com a questão ambiental, por que permitiu a ampliação da SA- 


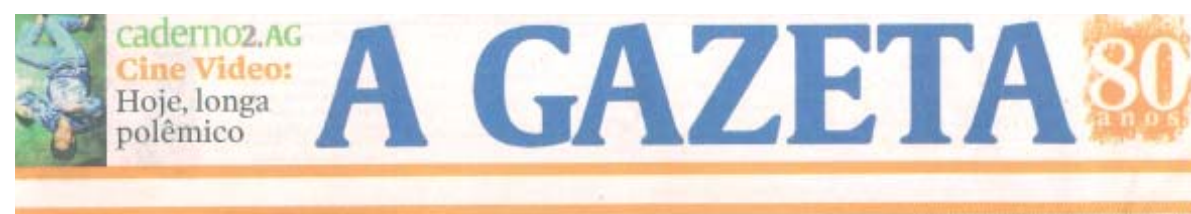
Virada estratégica. Chineses estariam buscando terrenos em Itapemirim e em Presidente Kennedy

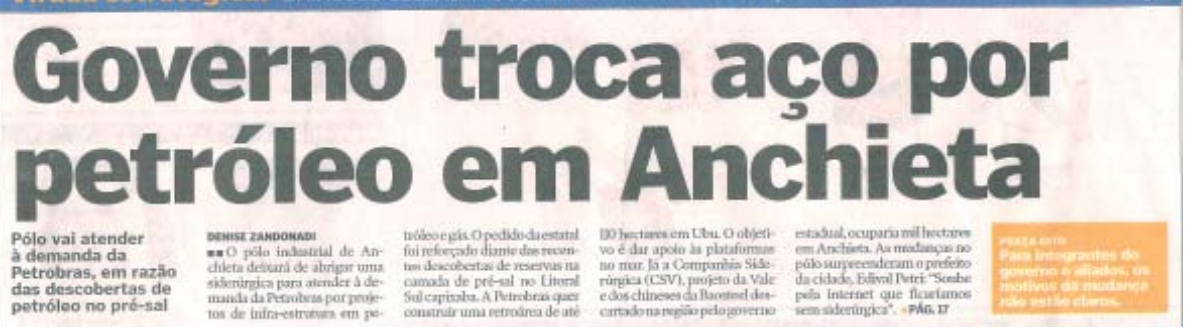

FG.65

\section{RG.65}

Um dos motivos especulados para suspender o projeto da sidenurgia seria a prionização das atividades petrolíferas. Fonte: A Gazeta, Vitória, 29 nov. 2008.

MARCO, com a construção da terceira usina de pelotização, estando ciente de que o índice de poluição em Anchieta chegou ao patamar de 91\% do índice limite estabelecido pelo Conama, e por que ainda conjugou a possibilidade de estabelecimento de outra siderúrgica como a Baosteel? Ao que tudo indica, o governo já sabia, ou já deveria saber, que o limite de poluição na região estava altíssimo. Os técnicos do Instituto Estadual do Meio Ambiente (IEMA) estavam, de fato, apavorados com a possibilidade de o projeto da siderúrgica ser aprovado, uma vez que o acordo entre as partes - governo e empresas - estava praticamente fechado. Há também os que alegam ter havido pressão da Petrobras em demanda por mais área na região para operação depois das recentes descobertas de petróleo na camada de pré-sal no litoral capixaba.

É preocupante pensarmos que, passados alguns meses, em maio de 2009, surgiu nova intenção de construção e instalação de um complexo minerador, siderúrgico e exportador no litoral sul do Espírito Santo. Essa segunda possibilidade, especulada pelo governo e divulgada na mídia, foi a de o grupo Ferrous Resources vir a se instalar no município de Presidente Kennedy (Microrregião Sul) para construção de outra siderúrgica. Em 2009, o grupo havia assinado um novo protocolo de intenções com a prefeitura e o Governo do Estado, ratificando a aplicação de recursos na região, estimados em torno de US $\$ 2,7$ bi inicialmente. A área adquirida pela empresa fica entre a foz do rio Itabapoana e Barra do Marobá, onde seria construído um porto.

Além da previsão de implantação da Ferrous no litoral sul, a VALE voltou 
a anunciar, no dia 30 de julho de 2009, a construção de uma siderúrgica em Anchieta, durante a apresentação dos resultados da empresa. O projeto da siderúrgica, desta vez denominada CSU (Companhia Siderúrgica de Ubu), tal como a Baosteel, teria capacidade para produzir 5 milhões de toneladas de aço por ano e criar 18 mil empregos, segundo o presidente da mineradora da VALE, Roger Agnelli, na apresentação do projeto ao Governo do Estado. A viabilidade de uma planta industrial desse porte em Ubu (Anchieta) depende, segundo a própria VALE, de um porto e de uma ferrovia. Portanto, as características do empreendimento são similares às das proposições da Baosteel; o que muda é apenas a "roupagem". O presidente da VALE afirmou ainda que iriam estudar como fazer o uso e o reúso da água para viabilizar o projeto sem desrespeitar nenhuma determinação ambiental, apesar de já ter sido constatada a incapacidade dos recursos hídricos, pela AAE, ao final de 2008.

Sobre o episódio de uma nova siderúrgica em Anchieta, veiculado na mídia em 2009, mesmo após ter sido vetada a instalação da Baosteel pelo governo do estado, alegando sérios danos ao meio ambiente, vale registrar aqui o protesto veemente feito ao Ministério Publico pelo morador Perseu Carvalho, indignado com a possibilidade da CSU se tornar uma realidade:

A VALE voltou à carga. Desvinculou-se (pelo menos aparentemente) dos chineses, cujos índices de rejeição pelos moradores da região são alarmantes, maquiou o projeto original e está novamente empurrando o projeto de siderurgia "garganta à baixo" da população. Ora, se há alguns meses a siderúrgica não era viável, como o é agora? Será que a água do município aumentou? Será que o pó de minério que a população respira diminuiu? Nada disso pelo que consta aconteceu. O fato é que uma nova siderúrgica na região, conforme dados da própria VALE, vai colocar mais 18 mil pessoas em um municipio com 20 mil habitantes; vai inviabilizar o turismo na região, causar um tremendo impacto social e ambiental. O projeto vem sendo desenvolvido no momento a passos rápidos, com pouca participação das comunidades, a participação, até o momento, resumida a pequenas assembléias publicas, onde poucos e humildes moradores locais se defrontam com senhores bem vestidos, que acenam com as velhas promessas de emprego, progresso e desenvolvimento. Será que um membro do Ministério Público não deveria obrigatoriamente participar 
destas reuniões? Quem no E. Santo está acompanhando este processo? A quem os cidadãos comuns podem recorrer, pois há muito se perdeu a esperança nas autoridades locais, e mesmo os órgãos encarregados de zelar pelo meio ambiente estão sabidamente sem autonomia para enfrentar um poderio econômico do porte de uma VALE. ${ }^{131}$

Perseu Seixas Carvalho

(morador de Ubu, médico e professor da UFES)

Em 2009, ao ser indagado por um jornalista como conseguiria deixar para decidir em cima da hora a tecnologia que será usada como alternativa à demanda de água, o coordenador executivo da CSU, Marcos Chiorboli, disse que a estratégia será a seguinte: "vamos fazer o projeto de engenharia conceitual e vamos fazendo a engenharia básica que poderá ser, depois, ajustada à tecnologia que for trazida pelo parceiro ou que for escolhida pela empresa". Chiorboli fez questão de deixar claro por que a VALE escolheu o balneário de Ubu como local para implantar seu quarto projeto siderúrgico no país: "esta região tem um diferencial competitivo fantástico em relação aos outros locais que é a proximidade da matéria-prima (minério) com o porto, já operado pela SAMARCO."132 Portanto, a VALE ainda não apresentou nenhum estudo efetivo que viabilize o fornecimento de água para a atividade siderúrgica. Considerando a experiência do município de Anchieta com relação às promessas de medidas compensatórias para o meio ambiente, que ainda não foram cumpridas pela SAMARCO mineradora, há que se ter uma perspectiva preocupante quanto ao futuro diante da possibilidade de instalação de mais uma siderúrgica.

O Grupo de Apoio ao Meio Ambiente - GAMA - fez uma nota de repúdio à imprensa questionando a instalação de mais uma usina e a retomada do projeto da Siderúrgica em Ubu (Anchieta), uma vez que não houve, até o momento, qualquer alteração no quadro ambiental, após resultado das avaliações técnicas da AAE. Em 2005, foi elaborado o TAC ${ }^{133}$ (Ministério Público, IEMA e SAMARCO), com a finalidade de amenizar o passivo ambiental da Terceira Usina de Pelotizaçâo, o que permitiria o licencia-

131 Carta de protesto encaminhado ao Ministério Público via email em 30 set 2009.

132 Entrevista concedida ao jornal A Gazeta, Vitória, 29 ago. 2009. Caderno Economia. p.15.

133 TAC - Termo de Compromisso de Ajuste de Conduta. O TAC é um acordo entre o Ministério Público e a parte interessada, de modo que esta se comprometa a agir de acordo com as leis trabalhistas, sob pena de multa. 
mento. Uma das exigências consistiu no não descarte de efluente líquido da Barragem Norte para o restante da lagoa Mãe-Bá. Entretanto, o que se observa é que a SAMARCO, até o presente momento, continua despejando seus efluentes nesse frágil corpo d'água. Há ainda várias outras condicionantes, prometidas pela SAMARCO, que ainda não foram concluídas, como há também o não cumprimento de medidas mitigadoras, compensatórios e planos de controle, estabelecidos no EIA-Rima da Terceira Usina dessa empresa mineradora.

O que era condicionante da primeira e segunda usina da SAMARCO foi mesmo integrado ao TAC da SAMARCO, assinado em setembro de 2004. Já se foram cinco anos, e só agora (2009) os estudos terão início. Para efetivarem o compromisso assinado, quanto tempo ainda vai se arrastar? Numa reunião na SAMARCO, os técnicos da Cepemar - a empresa responsável pelos estudos - argumentaram que a demora é devida à dificuldade para obter licenças do Ibama para os estudos e que isso pode demorar quase um ano. E, com mal disfarçado orgulho, os técnicos afirmaram ser esse plano inédito ainda no Brasil, e, por isso, não há referências para embasar os estudos.

Quando dissemos que a situação das lagoas agora já é muito diferente daquela de há cinco anos e que, pelo andar da carruagem, quando o estudo estiver pronto já não haverá mais nada para salvar, foi-nos dito que, de qualquer forma, o destino de todas as lagoas é desaparecer. Claro, disso já sabíamos. O destino da terra também é desaparecer assim como do sol e de tudo o que há no universo.

Ilda de Freitas (PROGAIA) $)^{134}$

A população em geral não tem o controle seja do nível de contaminação do ar, seja do grau de cumprimento dessas determinações legais, impostos à SAMARCO. Antes que estudos de viabilidade ambiental sejam realizados e que seja autorizado qualquer outro empreendimento, os habitantes de Anchieta precisam ter o controle dessas informações, que dizem respeito às suas condições de vida e de saúde. Os grupos organizados já solicitaram ao IEMA (Instituto Estadual do Meio Ambiente) a instalação de me-

134 Presidente do PROGAIA - Programa de Apoio e Interação Ambiental.Coordenadora do Fórum de Entidades Civis Organizadas do Litoral Sul do ES em carta dirigida aos munícipes e associados em 18 out 2009. 
didores de contaminação do ar, a serem distribuídos em diversos pontos do município, similares àqueles de medição de temperatura. Eles exigem também a divulgação do nível de cumprimento das condicionantes e dos TACs referentes a todos os empreendimentos produtivos (SAMARCO e Petrobras), para que possam acompanhar e ter o controle sobre o cumprimento de suas exigências.

É fator agravante da situação a forma de condução da política brasileira no trato das questões públicas, estando ela sempre apoiada em instituições que são estruturadas setorialmente e que funcionam tão somente voltadas para questões que lhe dizem respeito. Dessa forma, a crise relativa aos projetos de magnitude, a qual envolve diretamente paradigmas socioambientais, se desenvolve em duas velocidades: uma velocidade acelerada para a deterioração e outra extremamente reduzida para a adoção de soluções adotadas, insignificantes perante a magnitude e a complexidade do conflito estabelecido. Outro problema que se apresenta é o da falta de continuidade dos processos iniciados, pautados pelas dificuldades encontradas no confronto entre poder, aspirações sociais e resultados concretos, muito em decorrência também da resistência da gestão empresarial em estabelecer um diálogo efetivo com o poder representativo local.

Para Furtado (1996), o Estado, numa sociedade de classes, onde grupos concorrentes competem e quase sempre dividem de alguma forma o poder, constitui uma instituição mais complexa, de objetivos menos definidos e cambiantes, portanto, menos linear em sua evolução. Não há dúvida de que as grandes empresas detêm um considerável poder no plano social, pois controlam as formas de invenção mais poderosas, aquelas fundadas na técnica e no controle do aparelho de produção. Segundo o autor, essa debilidade do Estado como instrumento de direção e coordenação das atividades econômicas, em função de algo que se possa definir como o interesse da coletividade local, passa a ser um fator significativo no processo evolutivo de construção da democracia (FURTADO, 1996, p.68).

Embora a lógica da ação do Estado, em uma sociedade capitalista, tenda a ser a da reprodução vigente, há que se acreditar na possibilidade de alternativas pautadas num processo mais democrático de construção da cidadania. Contradições e conflitos, se bem explorados, podem condu- 
zir a situações bem diferentes daquelas a que pode conduzir um simples reforço da dominação, perpetuamente renovado, por parte do Estado. A construção de uma identidade é um processo e, como tal, sujeita a mudanças. Há que se ter, portanto, a autonomia individual e coletiva para fornecer fundamentos sólidos na defesa simultânea de mecanismos e instituições propiciadores de integração, o que constitui a vocação da ideia de cidadania, e de uma margem de manobra institucional para a proteção de identidades legítimas. O envolvimento e o intercâmbio entre os diversos atores sociais são imprescindíveis nesse processo, de forma a destituir a banalização do caráter cotidiano dos problemas urbanos, buscando novos arranjos institucionais e mediando os interesses e conflitos apresentados. 
286| CAṔ́TULO 8 

288| CAṔ́TULO 9 


\section{AS INTERVENÇÕES: COTIDIANO E IMAGINÁRIO SOCIAL}

As demandas que se apresentam para Anchieta possuem não apenas um sentido propriamente econômico do território, visto como fonte de riqueza a ser trabalhada, mas também um sentido simbólico - o território como universo sensorial, como força de resistência a ser submetida pela ação humana, constituindo ele o cenário da experiência dos indivíduos, da memória social para si mesmo e para o mundo.

A memória urbana é a própria cidade, que guarda os traços dos seus processos de permanência e de transformação constante. Toda a memória, tanto a individual como a coletiva, se apoia em bases concretas ou materiais. As práticas espaciais, conforme sejam conduzidas, podem proporcionar um distanciamento do cotidiano do lugar, sobrecarregando as estruturas existentes e alterando os significados incorporados pela tradição centenária. Outras configurações devem ser criadas no relacionamento com o passado, de tal maneira a relevar a possibilidade de uma nova prática narrativa, baseada no excepcional do lugar, e de modo a recriar, adaptar, o desejo (de mudança) do presente.

\footnotetext{
Uma sociedade é uma realidade histórica com características peculiares. Ela se concretiza por meio de longa vida em comum num determinado território. As atividades econômicas fornecem os artefatos que, produzidos no curso da história, constituirão determinada civilização material. Contudo, essa civilização só se tornará expressiva se houver entre os membros de uma comunidade pontos comuns que constituam suas referências culturais e de identidade[...] A cultura é igualmente um elemento de coesão na comunidade, atuando tanto como força criadora quanto como força conservadora. Tanto ela transmite as idéias, os sentimentos e as aspirações, quanto mantém as conquistas obtidas e preserva os bens adquiridos.
}

(SOMEKH, 2001, p.111)

Esse sistema complexo de estruturas espaciais e humanas estabelece uma rede de relações significativas em constante mudança, em equilíbrio dinâmico no ritmo de uma sociedade localizada. Portanto, essas estruturas estão gerando, sempre, novos significados, conforme o seu valor sistêmico 
e sua posição como objeto no contexto espacial, ou seja, seu valor relativo dentro de um sistema mais amplo. E todas as estruturas espaciais ou institucionais da cidade se caracterizam como elementos essencialmente carregados de uma força informacional e de uma memória técnica de domínio do homem sobre a natureza e de afirmação do seu território. Assim, a cidade como totalidade e, mesmo, suas partes já apresentam em si uma lógica espacial simbólica muito peculiar, onde engendram relações com os sistemas de objetos e os sistemas de ações humanas (SANTOS, 1994).

Castoriadis (1982) argumenta que existe um componente imaginário em todo símbolo e em qualquer nível que ele se apresente. O termo imaginário poder-se-ia empregar para falar de algo "inventado", seja uma estória imaginada ou um deslocamento dos símbolos usados, isto é, algo subjacente investido de outras significações, metáforas ou metonímias, fruto da imaginação. O imaginário será sempre algo descolado do real. E, dessa forma, usa o simbolismo como representação e a percepção do espaçotempo real, não somente para exprimir-se, o que é óbvio, mas para "existir" e passar do virtual a qualquer coisa a mais (CASTORIADIS, 1982, p. 154).

O imaginário da cidade é, de certa forma, o real transmutado em algo que ele não é, mas como forma de representação ou, como ensina Baudrillard (1991), como simulação. Essa capacidade simbólica estabelecida por um vínculo permanente entre a realidade das coisas e sua representação é uma função imaginária que se propaga por meio dos elementos informacionais. Essa articulação da sociedade com o espaço por meio da técnica, definindo sua identidade cultural e suas relações com os elementos urbanísticos é, pois, a representação de um imaginário.

Leite (1998), com base no pensamento freudiano, afirma que o imaginário é uma forma de pensamento que se afasta explicitamente do real e se apoia na memória, para organizá-la objetivando, não o conhecimento da realidade, mas para a estruturação de cenários irreais e a criação de um universo fictício: "apesar do pensamento imaginário resultar da produção de fantasias que não são nem falsas nem verdadeiras, o imaginário aponta para uma realidade possível, situada além da visibilidade existente e, portanto, potencialmente capaz de concretizar-se como alternativa ao presen- 
te “(LEITE, 1998, p.54).

Ferrara entende o imaginário pensado como dissociado do real e como manifestação da estrutura dicotômica que caracteriza a cultura ocidental (sujeito/objeto; consciente e inconsciente, entre outros). Considera ainda que a unidade imagem/imaginário é responsável pela geração do significado. Para a autora, "o pragmatismo da imagem está individual e necessariamente ligado ao resgate da experiência urbana que supõe uma inteligibilidade do presente e do passado, como condição de escolha da ação capaz de alterar comportamentos" (FERRARA, 2000, p.117).

Diante de uma nova realidade que se apresenta - o Pólo Industrial de Anchieta - o desafio é tentar compreender o objeto técnico como elemento de ressignificação da cidade e, por meio dela, dos valores culturais de seus cidadãos, de uma coletividade. Walter Benjamin (apud GAGNEBIN, 2006) entendia que os grandes domínios do passado eram abandonados ao esquecimento porque não contariam para o desenvolvimento do "espírito". Benjamin argumenta que, ao se pensar a construção da história, há de se ter esse cuidado pelo detalhe, pelo resto, pelos resquícios; sua preocupação, porém, não visa a uma descrição exaustiva, mas a uma história "a contrapelo": não aquela dos vencedores, mas aquela que poderia ter sido outra, que foi sufocada, mas deixou interrogações e lacunas que são tantos sinais de alteridade e de resistência. ${ }^{135}$ Para o autor, cabe ao presente, justamente, reconhecer esses sinais e, quem sabe, retomá-los e assumir suas promessas de alteridade e de resistência. No entender de Benjamim, essa relação do presente com o passado não pode, então, seguir os moldes da identificação afetiva ou empatia (Einfühlung) com os grandes feitos ou heróis do passado, tais quais são descritos pela história oficial; pelo contrário, deve desconstruir a narrativa da "história dos vencedores" e indicar outras possibilidades narrativas e históricas, silenciadas, esquecidas ou recalcadas.

135 Essa busca de outra história possível leva Benjamin a lançar mão de paradigmas teóricos pouco usados até aí, a saber, o paradigma psicanalítico de Freud e estético de Proust. Não é o caso aqui entrar em detalhes a respeito desse pressuposto; podemos, porém, ressaltar que tanto Freud quanto Proust procuram, justamente, por uma nova relação do presente com o passado, isto é, por uma nova definição da memória e da identidade subjetiva. Ao tentar transpor essas redefinições do domínio da subjetividade para o da história coletiva e do território estético para o político, Benjamin enfrenta grandes dificuldades, das quais é perfeitamente consciente. Contudo, permanece a questão de uma narrativa histórica que soubesse responder no presente às interpelações silenciadas do passado. GAGNEBIN, Jeanne Marie. Benjamin e as teses. Disponível em <:www.uol.com.br> Acesso em set.2006. 
E é justamente nos lugares de vida cotidiana que se abre a possibilidade de resgatar as especificidades muitas vezes esquecidas, propositadamente forjadas ou omitidas pela história oficial a que se refere Benjamim.

É evidente que o lugar se define, inicialmente, como a identidade histórica que liga o homem ao local onde a vida se processa, mas, cada vez mais, a "situação" se vê influenciada pelas relações do lugar com um espaço mais amplo. $\mathrm{O}$ fato de o homem ter a possibilidade de mover-se com bastante fluidez no território, base concreta do desenvolvimento das forças produtivas, enche o domínio do imaginário e o domínio da vida material; por outro lado, essa possibilidade é tolhida em sua plenitude pela limitação dos possíveis mecanismos de intervenção social nos espaços onde a vida se realiza: o cotidiano vivido. A modernização crescente é, portanto, marcada por essa ambiguidade entre o futuro progressista e certa nostalgia que parte em busca da poética das tradições e a historiografia dos lugares de vida. A nova economia em escala global em rede faz com que a sociedade dependa da sua capacidade de gerar, processar e aplicar de forma eficiente a informação baseada em conhecimentos.

Estabelecer relações com a paisagem em transformação significa entender o Pólo Anchieta como fenômeno que marca uma etapa do processo de desenvolvimento. A universalização dos modos de vida material pode criar novos valores identitários. A mobilidade intensa e a facilidade das comunicações sugerem situações inteiramente novas para a imensa maioria da população de Anchieta. Novas oportunidades se abrem para que cada habitante possa fazer, ou não, a sua opção.

Para Harootunian ${ }^{136}$ (2000), todo evento excepcional tem conotações, temporalidades, relembrando que algo ocorreu num determinado espaço de tempo, correspondendo a uma determinada ordem temporal. Desse modo, todo evento histórico deixa uma marca, uma inscrição. Na medida em que as estruturas do poder econômico e político são manifestadas e legitimadas, reforça-se a pertinência da abordagem dos fenômenos do cotidiano como elementos fundamentais à compreensão da totalidade.

136 HAROOTUNIAN, Harry. History's Disquiet: modernity, cultural pratice, and the question of everyday life. New York: Columbia University Press, 2000. 
Ferrara argumenta que a escala de valores que fundamenta o imaginário urbano é particular e se pauta nos meandros do indivíduo, no emaranhado dos seus sentimentos, memória, experiências e informações urbanas.

Privado, o imaginário não condiz com a ordem e a segurança do código, mas é tênue, instável e, sobretudo, contínuo e indeterminado; por isso não se constrói fisicamente, mas é apenas, indiretamente sugerido. Daí talvez a naturalidade com que as imagens se materializam aos nossos olhos, a evidente facilidade com que, aos nossos olhos, as paisagens se tornam reais ou metáforas do visível.

(FERRARA, 2000, p.129)

Os projetos vinculados ao Polo Anchieta estão sendo encaminhados com forte divulgação na mídia, cuja produção imagética e virtual assume maior importância que a própria narratividade da paisagem em si, deslocando, assim, o foco que confere a identidade ao lugar. O que é virtual tenta recriar, dar um novo sentido, qualificar a cidade e a arquitetura tal qual a visão que interessa ressaltar, fazendo da forma urbana suporte de múltiplos discursos, que afluem ou não para um ponto em comum, mas que se mesclam atuando sobre ideias e comportamentos individuais e coletivos. A visibilidade abandona o grande plano e se constrói no close das imagens, que procuram criar uma referência de valores para a comunidade, que podem estar presentes ou não. Uma imagem urbana que nem sempre corresponde à realidade dos fatos, mas que muitas vezes, preenche lacunas. Nessa perspectiva analítica, a visão daquilo que nos apresenta, em um determinado momento, como paisagem, é dificultada pela aparente banalidade de um mundo concreto.

As dragagens, feitas para manter o calado do porto, e os navios das petrolíferas, mexem muito com o fundo do mar, e espantam os peixes. Além disso, as plataformas de petróleo atraem o pescado, que fica ao redor delas. O problema é que não é permitido que pesquemos no local. Isso dificulta demais o nosso trabalho. [...] Não temos décimo terceiro, previdência, FGTS e outros benefícios. Na pesca, se a gente não trabalha, não come. Os pescadores mais novos estão largando a profissão e indo trabalhar nas empresas que estão chegando. Só sobrou quem está com mais de 40 anos. Eu só não saio porque já tenho 55 anos. 
No contexto do Polo de Anchieta, a paisagem tem uma "tecnicidade" embutida e uma "desejabilidade" manifestada (LEITE, 2009). Percebe-se, na fala do pescador, a incerteza "do que virá e de como virá". Sentimentos ambíguos deixam uma boa parte da comunidade local atenta. No limiar de transformações a serem empreendidas na microrregião sul, especialmente em Anchieta, importa perceber como os instrumentos de imposição do comportamento social desejado podem influir na criação de uma imagem ideal, uma espécie de cenário desejável e aceito pela comunidade. Nesse sentido, Leite dá uma importante contribuição ao associar o pensamento freudiano - o imaginário social - à possibilidade de entender o que está sendo representado na paisagem:

Entre os muitos motivos que alimentam a sensação de manipulação, de ocultação da verdade está o fato de que a paisagem pode ser facilmente confundida com as instâncias econômica, política e ideológica do espaço social, que nela se fazem presentes com maior ou menor intensidade em cada momento histórico. Se a representação dos objetos funcionais é manipulada pelos mecanismos de regulação, à paisagem cabe o papel de revelar a falsificação decorrente do descompasso entre as relações sociais que a produzem e a imagem que as representa, abrindo, através da percepção, caminho para mudanças desejadas.

(LEITE, 1998, p.52)

Para o casal Eduardo e Andréa Martins, que vieram de Brasília há dois anos em busca de novas oportunidades em Anchieta e montaram uma lan house (casa que permite acesso à Internet), o comportamento é de estranhamento. Reclamam dos poucos serviços oferecidos na cidade: "a única conexão de Internet da cidade, via rádio, é muito lenta. Além disso, não são oferecidos serviços básicos como TV a cabo, cinema, restaurantes e lanchonetes." Já para o proprietário de uma pousada em Castelhanos, Nereo Marchesotti, a preocupação com os novos horizontes causa certo espanto: "Anchieta não está preparada para esse impacto todo. Não houve planejamento e o preço disso a gente conhece bem", diz, ele ${ }^{138}$. O presi- 
dente da Câmara de Vereadores expressa suas apreensões: Já temos um Plano Diretor Municipal, mas a gente sabe
que mesmo com as regras estabelecidas a cidade vai sofrer.
Poluição? Vai ter. Poluição industrial, de carros circulan-
do, até de grande concentração de pessoas. Em dez anos,
a população do município deve, no mínimo, triplicar. Meu
medo é que isso aqui vire uma nova Macaé. [...] Vai ser bom
para o crescimento da receita, mas péssimo para a nossa
qualidade de vida.

Edson Souza

(presidente da Câmara dos Vereadores) $)^{139}$

De olho na chegada das grandes empresas, o empresário do ramo de autopeças, Charles Amorim, dobrou o tamanho do seu negócio: "eu tinha uma oficina e uma loja pequena de autopeças. Pensando na chegada das empreiteiras, fechei a oficina e dobrei o tamanho da loja". Segundo ele, o investimento ainda não teve retorno, mas, mesmo assim, Amorim já tem planos para expansão, conforme relato: “a partir de 2009, quando todas as obras estiverem em curso, com certeza, o retorno virá. Já tenho até planos para ampliação". O lojista salienta que, se não existisse um horizonte de crescimento regional, não faria o investimento.

Essas impressões, essas sugestões, os gestos, esses discursos não verbais com características metafóricas assinalam o caráter de representação, ou seja, salientam, realçam a dimensão sígnica de mediação pela qual a cidade se faz conhecida por seu interlocutor. O olhar gerado pelas condições históricas que atualmente se apresentam para os moradores de Anchieta é, por vezes, invadido pela angústia, um olhar que não mais encontra a confiança tranquila que sempre se acostumou atribuir à paisagem. Não se trata aqui do registro pretensamente objetivo daquilo que os olhos naturalmente captam. É um olhar que, cada vez mais, encontra como foco os objetos técnicos, fundamentalmente urbanos, e que se tornam imperativos a outros olhares, sejam eles desiderativos ou nostálgicos. O olhar individual ou coletivo anseia apenas por estar no lugar, ou seja, o lugar onde o indivíduo possa se reconhecer.

139 TURISMO e meio ambiente em busca de soluções. Vitória, 16 dez. 2007. Economia, p.27 
Quando um objeto técnico é mais amplo que o lugar, o imaginário social fica deslocado para a ordem do fragmento, percebida, por vezes, por meio de situações básicas, monótonas e inalteráveis. ${ }^{140}$ De fato, de tanto desviarmos os olhos do que já nos vai custando ver, arriscamo-nos, mesmo sem querer, a perder o jeito de ver a realidade ao nosso lado, a qual continua a ser parte inseparável do mundo. A possibilidade de perceber e compreender o que está sendo formulado e representado na paisagem, assim como a sua gênese, é o início do processo que permite desejar alterações na ordem estabelecida pelo modo de produção atual. Mas há limitações nesse processo. É o caso da maioria dos moradores de Anchieta.

[...] nas condições sociais que, historicamente, prevalecem, os homens precisam proteger-se de si mesmos, de sua capacidade de desejar alterações nas relações sociais de produção estabelecidas e, para isso, contam com mecanismos de defesa, isto é, acionam dispositivos inibidores de consciência, que tornam invisíveis as percepções da realidade exterior associadas a impulsos de transgressão. Esses mecanismos de autoproteção, que coincidem com as formas de proteção social, são ilusões, ou falsificações da consciência [...] não é a realidade exterior que me ilude, mas é minha percepção dela que canaliza para a ilusão, visa perpetuar o modo de produção e reprodução das relações sociais.

FREUD $^{141}$ apud LEITE (1998, p.53)

Desse modo, conforme argumentação de Freud, essa autocensura reforça e perpetua a reprodução do modo capitalista e das relações sociais estabelecidas, privilegiando o poder e a riqueza para poucos.

Pode-se destacar o fato de que algumas das comunidades tradicionais do município de Anchieta, por terem se desenvolvido e se estabelecido em espaços territoriais contíguos aos que foram posteriormente identificados como de expansão para uso industrial, no PDM de Anchieta, apesar de não estarem diretamente inseridas no interior do Polígono do Polo, devem merecer a atenção e os devidos cuidados para que não sejam expulsas ou mesmo prejudicadas. As comunidades Chapada do A e do Monteiro estão localizadas próximas ao mangue, e a população residente é nativa e vive,

140 LEITE, Maria Ângela Faggin. As tramas da segregação. Tese (Livre Docência) - Faculdade de Arquitetura e Urbanismo da Universidade de São Paulo. São Paulo, 1998.

141 FREUD, S . Formulações sobre os dois princípios do funcionamento psíquico. 
em sua maioria, da cata do caranguejo. No contexto em que se prioriza o uso industrial, os valores da dinâmica socioambiental impressa no território ficam por entre outros motivos, não tão bem esclarecidos, favorecidos também pela dificuldade dos indivíduos e da coletividade que usufruem desse território de percebê-los.

Para Leite (2006, p.9-11), “o efeito mais evidente dessa modernização contínua a que o espaço está submetido é a desvalorização, senão mesmo a destruição localizada, mas não homogênea, de formas e habilidades do passado e, na esteira dessa destruição, novas formas são geradas para atender às ações reclamadas pelas particularidades do processo de modernização". As diversas interfaces do discurso ambientalista e do desenvolvimento sustentável, utilizado pelo poder público em parceria com o privado para implementação do Pólo, só se tornam cabíveis na medida em que traduzam também um significado favorável ao cotidiano local.

Há uma proposição teórica que sustenta a tese de que em condições de desigualdade social e de poder sobre os recursos ambientais, bem como de liberdade irrestrita de movimento para os capitais, o instrumentos correntes de controle ambiental tendem a aumentar os esforços e a desigualdade, sancionando a transferência de atividades predatórias para áreas onde é menor a resistência social. A mobilidade do capital tende correntemente a abandonar áreas de maior organização política e dirigir-se para áreas com menor nível de organização (ASCERALD, 2004, p.33).

Sem diminuir a importância de conquistas da sociedade no espaço público global, especialmente por meio das ONG's, não se pode, contudo, supervalorizá-las em termos de mudança social. Os governos engajam-se no discurso e concordam no diagnóstico, participam dos atos de forma espetacular, mas, depois, outros interesses falam mais alto. As organizações da sociedade civil, com poucos recursos, voltam-se para suas atividades de rotina, sem condições de realizar um acompanhamento mais sistemático das decisões e compromissos.

As chamadas audiências públicas constituem-se em reuniões onde senhores bem vestidos, tentando vender uma imagem de simpatia e usando os velhos chavões de geração de empregos, chegada de dinheiro e de progresso, 
iludem os poucos e humildes moradores das localidades, que se sentem sem a menor condição de enfrentar o poderio econômico e político que têm diante de si. Diante dessa impossibilidade, os representantes das pequenas comunidades tentam negociar algumas migalhas, na forma de compensação financeira para as associações de moradores, ou pequenas melhorias no local, melhorias essas que são de obrigação das prefeituras usando a arrecadação pública, obrigação esta que as prefeituras transferem para as empresas, perdendo desta forma sua autoridade e sua isenção no momento de vetar qualquer situação que vá prejudicar seus munícipes. Hoje mesmo, dia 30, está marcada uma reunião entre representantes da VALE e moradores de um povoado do município, chamado Ubu, que sobrevive do turismo e da pesca. As pessoas são humildes e sem argumentos e acho que deveria ter uma pessoa do Ministério Público presente. A minha pergunta é se isto pode ser feito e se pescador tem direito de negociar o mar, pois este, ao que me consta, é um bem de todos e não pode ser vendido ou poluído em troca de um punhado de moedas.

Perseu Carvalho ${ }^{142}$

(morador, médico e professor da UFES)

A compreensão dessas relações que se impõem mediante a implantação de objetos técnicos, e, portanto, estranhas ao contexto cotidiano vivido historicamente, podem ter diferentes desdobramentos, tanto analíticos como práticos. Os indivíduos diretamente envolvidos com a questão do Polo Anchieta, especialmente seus moradores, deparam-se constantemente com essas interlocuções perceptivas com a paisagem, a partir do momento em que se manifestam variáveis adversas àquilo que lhes já é familiar. Todos esses possíveis olhares, nostálgicos, de estranhamento, dos habitantes de Anchieta são passíveis de reflexão e de novas conotações acerca do valor que imprimem a cada objeto manifestado na paisagem. $\mathrm{O}$ que caracteriza essa nova paisagem vinculada ao Polo, onde o público e o privado se fundem, é a certeza de que aí tudo é passível de acontecer, de se deslocar; o risco iminente passa a ser constitutivo do lugar e atinge a todos indistintamente.

À paisagem entendida como construção coletiva pode-se, ademais, atribuir uma qualidade de manipulação, de oculta-

142 Carta dirigida ao Ministério Público em 30 set 2009 
ção da verdade, na medida em que o que ali está representado não corresponde à totalidade dos fatos, mas a uma visão parcial deles, muitas vezes em desacordo com os nossos desejos individuais.

(LEITE, 1998, p.52)

Para Leite (2004 a, p.67), a questão fundamental que se apresenta, é que já “não é mais possível desconsiderar a diversidade e a complexidade da sociedade civil como última instância de decisão, especialmente quando essa decisão é responsável pela viabilização de anseios tão diversos". Existe, portanto, uma dimensão política, resultante dos impactos das ações intervenientes no espaço, cujos interesses são diferenciados e, na maioria das vezes, conflitantes. Se a proteção de uma área de interesse ambiental requer restrições à urbanização e a atividades correlatas, é essencial que as autoridades públicas não considerem apenas alguns imperativos estruturais ou sistema lógico. As dimensões políticas e culturais do lugar devem ser incorporadas na implementação de programas que viabilizem metas do planejamento estratégico de âmbito fundamentalmente econômico com uma cidadania digna de sua população.

Para enfrentamento da situação inusitada que se apresenta para a região sul, vale rever como se dão os fóruns de participação. Uma das dificuldades da relação entre organizações da sociedade civil e poder político é a inexistência de canais permanentes de interlocução entre os diversos atores e estruturas de poder. O processo de descentralização, de uma forma ou de outra, ocorre no país, mas, de forma geral, nem sempre acompanhado dos mecanismos efetivos de participação. No entender de Teixeira (2002, p.103), "em muitos casos os instrumentos são criados sobretudo para legitimar governos, com uma retórica participacionista, formal.”

Em Anchieta, algumas organizações têm se constituído, seja em razão de necessidades imediatas, seja para defender-se de alguma situação indesejada. Entre os diversos tipos de organizações, cabe destacar o papel desenvolvido pelas ONGs, destacando-se aqui a atuação do Progaia, liderada pela ambientalista Ilda de Freitas. O Fórum de Entidades Civis do Litoral Sul pretende abranger todo o litoral Sul do ES, mas, por enquanto, conta apenas com representantes (permanentes) dos municípios de Anchieta, 
Guarapari e Piúma. As principais questões tratadas no Fórum de Entidades são levadas para discussão no Fórum de Ubu, este criado, por último, pelo Ministério Público. As reuniões são mensais.

Apesar de não conseguirem alavancar a proposta ao qual se propuseram no ato de sua criação, o Fórum de Ubu e Fórum das Entidades Civis do Litoral Sul desempenham papel importante no debate do Polo de Anchieta, criando novos espaços de participação por intermédio de blogs na internet e fazendo o papel de "educar" politicamente os cidadãos para os fatos de interesse público. Mesmo que essa interlocução mais efetiva ainda se dê no âmbito de seus líderes, os fóruns não estão suficientemente preparados com uma participação mais expressiva, de modo a garantir as proposições coletivas diante das hegemonias econômicas e políticas.

Os dados de desigualdade de poder no espaço social, tal como frequentemente denunciados pelos fóruns de participação de entidades do litoral sul, já existiam, mas a luta social na questão do Pólo lhes deu visibilidade. Mesmo levando em conta a importância estratégica desses fóruns, considera-se que o espaço de participação não pode se esgotar nesses mecanismos, pois há os excluídos, que estão fora de qualquer acesso à expressão de suas opiniões e/ou direitos. Ainda não há espaços próprios para esse tipo de participação "não organizada", além de não haver mecanismos plebiscitários de consulta. Muitos cidadãos não têm acesso às novas tecnologias de comunicação. Outro fator agravante é que a grande maioria dos municípios, e aí se inclui também Anchieta, é controlada por elites conservadoras. Pela aparente fragilidade com que se constituem esses espaços de discussão, o risco maior reside na possibilidade de as organizações perderem sua autonomia, inserindo-se na lógica do poder.

As relações sociais podem se mascarar à medida que os sistemas funcionais da sociedade vão-se estereotipando e os comportamentos convertemse em papéis. Na vida cotidiana, como vimos, a ação e o pensamento tendem a ser econômicos, ou seja, manifestam-se e funcionam na exata medida em que são imprescindíveis à continuação da cotidianidade.

Valendo-se da constatação de que a subjetividade (no sentido da individualidade, da pessoa, do sujeito) foi banida do pensamento materialista 
histórico, Heller (1972) a resgata e a coloca no centro do processo histórico, entendido como expressão do homem em busca de sua humanização. Uma de suas principais contribuições ao marxismo contemporâneo é, portanto, a colocação da temática do indivíduo no centro das reflexões. $\mathrm{E}$ o indivíduo a que a autora se refere não é um indivíduo abstrato ou excepcional, mas, sim, o indivíduo da vida cotidiana, isto é, o indivíduo voltado para as atividades necessárias à sua sobrevivência. Para Heller, quando a "exterioridade" encobre a "interioridade" e esta se empobrece, aliena-se uma propriedade característica do homem. Por isso, a autora adverte para o papel alienante da elaboração de metodologias para manipular os homens, em especial nas esferas da vida cotidiana que têm uma relação mais direta com a genericidade: o trabalho e a política. A técnica contribui, dessa forma, para acentuar, por meios científicos, a fetichização cotidiana (HELLER, 1972, p 38).

As relações entre o indivíduo e o papel social, porém, nem sempre são de total identificação, mesmo nas sociedades de comportamento manipulado e administrado. Heller refere-se a várias possibilidades dessa relação, que vão desde a plena identificação, que é a forma mais direta de expressão da alienação e de imersão na particularidade, até a recusa do papel. Nesse sentido, Heller, entre outros autores, ressalta a importância da cotidianidade como instrumento de superação dos conflitos individuais e coletivos.

Assim como não existe nenhuma relação social inteiramente alienada, tampouco há comportamentos humanos que se tenham cristalizado absolutamente em papéis [...] Além disso, em situações novas, surpreendentes, nas quais os estereótipos deixam de funcionar ou funcionam mal, restabelece-se sempre a unidade do cotidiano.

(HELLER, 1972, p.40)

Não é difícil perceber que a vida cotidiana é, dialeticamente, o lugar da dominação e da subversão ou mesmo da revolução. A passagem da particularidade, onde há alienação e inconsciência dela, para os pequenos grupos que se indagam "por quê?", "como?", e nos quais se estabelece uma relação libertadora, é feita de pequenas conquistas. $\mathrm{O}$ meio pelo qual se realiza essa passagem é a prática política, cotidiana, não necessariamente partidária. É no plano de um trabalho invisível em pequenos grupos que se toma consciência da alienação e é agindo que se acaba com essa alie- 
nação. Mais importante é que, ao privilegiar a vida cotidiana como lugar onde a sociedade adquire existência concreta, redefine-se o lugar onde se dão as transformações sociais.

O que se deve buscar e manter nas cidades é o valor concreto que a sociedade atribui aos seus lugares de vida, e não valores abstratos de objetos que, concebidos como respostas racionais a situações ideais, terminam por relacionarse apenas entre si, formando nos discursos um conjunto perfeito, mas inexistente. E é essa busca de perfeição que anula, no lugar, o saber e, por conseqüência, a cidadania.

(LEITE, 2004 b, p.55)

A globalização não é capaz de destruir os lugares. Eles se transformam com os processos globais, mas não se constituem apenas em um processo de homogeneização. Entre o lugar e o mundo estabelecem-se relações dialéticas: o global se concretiza nos lugares, mas não sem resistência ou subversão. No lugar se dá efetivamente, "o embate das diferentes ações e suas intenções; se processam dialeticamente solidariedades orgânicas (da co-presença, da continuidade espacial) e organizacionais (das ordens, da distância e racionalidade econômica). Cabe ao lugar uma força reativa concreta e cotidiana aos processos de globalização, cabe ao cidadão tomar consciência. O lugar transforma o mundo em ato e potência.

(QUEIROGA, 2001, p.330)

O desafio, portanto, é a redescoberta do lugar, dentro dessa dimensão global, aquilo que é a sua essência em suas variáveis: objetos; ações; técnica e tempo. É justamente nas relações cotidianas, que se torna possível o rompimento desses limites. Ao estabelecerem-se relações de proximidades se dá essencialmente a revelação dos pontos em comum, aqui entendidos por laços culturais, onde acontece o exercício da solidariedade, enfim, da identidade. O sonho representa, para o cidadão, a não "aceitação resignada da impotência de todos os dias diante do factível, mas a vivência do estranhamento mediada pela consciência crítica dessa impotência" (HELLER, 1972, p.37) 


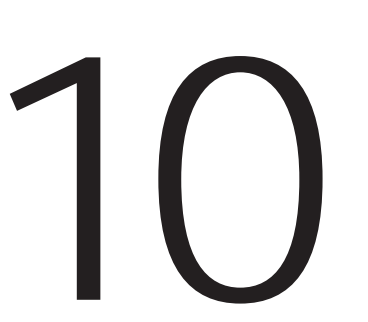

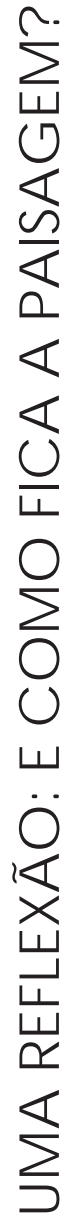

Quando eu olhava pela janela não via apenas o Bósforo e os navios que desciam ou subiam lentos os canais tão conhecidos, via também os jardins entre as casas, as velhas mansões que ainda não haviam sido demolidas e as crianças que brincavam entre seus muros derrubados.

Pamuk (2007) 
304| CAPÍTULO 10 


\section{UMA REFEXÃO: E COMO RCA A PAISAGEM?}

Haviam-me questionado, durante o desenvolvimento da tese, por que eu haveria de focar, em determinada parte do trabalho, uma imagem de Anchieta que enquadrava uma bela composição do pôr do sol com o mar, pressupondo uma visão "romântica" da paisagem. Essa imagem não estaria, assim, propriamente em consonância com o aporte teórico conceitual que explica o movimento inerente à paisagem e as relações que se estabelecem no espaço, e, por conseguinte, na paisagem. Fiquei um pouco melindrada diante de tal questionamento e talvez fosse o caso de suprimir a tal imagem. Entretanto, antes de fazê-lo, surgiu-me a necessidade de uma reflexão a respeito: Há forma de ver a paisagem sob determinado ângulo que deva ser preponderante? Por que não poderia eu pensar a perpetuação de uma imagem tão enigmática quanto divina, restauradora da vida moderna? O meu encantamento diante da paisagem é algo que deveria ser perpassado pela urgência de uma modernidade galopante?

Independentemente do olhar objetivo, há múltiplos outros olhares sobre a paisagem. $\mathrm{Na}$ autonomia do olhar, talvez resida a força e a liberdade. A essa ideia eu não poderia sucumbir. Seria, pois, necessário retomar alguns conceitos de paisagem para focar o seu conjunto, sem esquecer que a paisagem deve, em escalas apropriadas, acolher o individual e o coletivo, a razão e a emoção.

O estudo da paisagem, como categoria de análise do espaço, apresenta interfaces entre várias áreas do conhecimento e a das ciências urbanas, o que dificulta o estabelecimento de limites claros para a reflexão sobre seus conceitos. A concepção racionalista que colocou o espaço como responsável pela produção da paisagem urbana abriu caminho para uma concepção dialética e flexível, na qual se fazem presentes conteúdos históricos, geográficos, culturais. Dependendo do âmbito de análise a que esses conteúdos são submetidos, a abordagem conceitual sobre a paisagem pode ser similar, complementar ou mesmo divergente. É o caso, controverso, por vezes, dos critérios e parâmetros para entendimento da paisagem adotados por arquitetos, paisagistas e geógrafos. 
Apesar de algumas divergências na forma de abordar conceitualmente a paisagem, sabemos que poucas são as paisagens que não têm a intervenção do homem, mesmo que se apresentem preponderantemente como elementos da base natural da paisagem. Segundo Magnoli, a interação da sociedade humana com o suporte biofísico se dá no espaço geográfico pelas adaptações e transformações das sucessivas formas encontradas, elaboradas e reelaboradas. A essas conformações, configurações, carregadas de interação social com o suporte, a autora denomina de "paisagens" (MAGNOLI, 2006, p. 241). A paisagem, portanto, é considerada como um produto, resultante de um processo social, de ocupação e de gestão de um território, e como um sistema, na medida em que, a partir de qualquer ação sobre ela impressa, com certeza haverá uma reação correspondente, que, no caso, equivale ao surgimento de uma alteração morfológica parcial ou total.

Dessa forma, as paisagens, dos menores aos maiores ambientes, acham-se carregadas de informações, sendo ponto de partida para outras averiguações que, por sua vez, dependem da capacidade perceptiva do observador. O observador tem um papel ativo na percepção do mundo e uma participação criativa no desenvolvimento de uma determinada imagem. No momento atual, o valor universal do modo de produção representa a base material para a compreensão de paisagens em constante e rápida transformação. Augé tenta explicar esse sentimento ambíguo presente no olhar contemporâneo sobre a paisagem:

O movimento acrescenta à coexistência dos mundos e à experiência particular do lugar antropológico e daquele que não o é mais, uma experiência particular de uma forma de solidão e, em sentido literal, de uma "tomada de posição" - a experiência daquele que, diante da paisagem que é obrigado a contemplar e que não pode contemplar, tira da consciência dessa atitude um prazer raro e, às vezes, melancólico. Portanto, não é de se espantar que seja entre os viajantes "acidentais", de pretexto ou de ocasião, que estejamos aptos à evocação profética do espaço, onde nem a identidade, nem a relação, nem a história fazem realmente sentido, onde a solidão é sentida como superação ou esvaziamento da individualidade, onde só o movimento das imagens deixa entrever, por instantes, àquele que as olha fugir, a hipótese de um passado e a possibilidade de um 
Magnoli (2006) também fala da paisagem como possibilidade de conexão entre o mundo do sonho e o mundo da vida cotidiana, "o sonho como modalidade de interpretação, do ver a vida". E a autora prossegue com o pensamento de Martins (1996, apud MAGNOLI, 2006), segundo o qual "cada sonhador elabora o sonho e re-elabora ao interpretá-lo através de um estilo cognitivo próprio, de acordo com sua cultura”. E Magnoli complementa: "cada sonhador estabelece uma ponte entre as incoerências as quais experimenta no mundo interativo; no sonho, as defesas da racionalidade e vigília são recolhidas" (MAGNOLI, 2006, p.149).

O indivíduo estabelece relações com a paisagem e lhe atribui significados, ou seja, apreende a diferença que se pode encontrar num conjunto de fatos rotineiros que, lidos na sua diferença, permitem transformar o hábito, a rotina em alguma coisa perceptível. A interlocução entre sujeito e objeto é fundamental para compreensão dos mecanismos que operam na paisagem. Nessa perspectiva, o olhar constitui um instrumento de mediação entre o real físico e concreto e a capacidade perceptiva que acende o conhecimento e a imaginação. Essa conjunção de estímulos coordenados constitui a imagem apreendida pelo olhar. A paisagem é também da ordem da imagem, seja esta uma imagem mental, verbal, inscrita sobre uma tela, ou realizada sobre um território. Toda imagem registra o elemento visual dos processos de representação, oscilando, porém, entre o hábito e a experiência de ver. Como consequência disso, é possível falar em visualidade, que corresponde à imagem que se constata no visual físico e concreto, e em visibilidade, que corresponde à elaboração reflexiva do dado visual, transformando-o em fluxo cognitivo e evolutivo (FERRARA, 2002, p.73). A curiosidade está constantemente atrás da novidade, na busca de outro objeto que se imagina mais satisfatório. O que a paisagem revela de tão inquietante? Cada um encontra resposta em sua própria experiência.

A arte em quase todas as suas dimensões sempre interpretou as condições existenciais, e o artista, a sua visão particular do mundo. $O$ intercâmbio entre a ciência e arte, no que concerne à paisagem, é muito mais profundo e mais frequente do que geralmente se supõe. O século XVIII ressaltou as implicações de diferenciação social vinculadas ao olhar. Assim, discute-se 
a inserção do homem nesse contexto e como ele dialoga sua consciência "finita" com a "infinitude" da paisagem e do lugar. A analogia de experiências na paisagem conduz a análises, por vezes, opostas. Se, para uns, o olhar sobre a paisagem reconduz a uma introspecção interior, para outros, ao contrário, a presença diante da paisagem torna sensível a afirmação de um eu sentimental e provoca mesmo um esquecimento de si próprio.

Para Lynch, cada cidadão tem vastas associações com alguma parte de sua cidade, cuja imagem fica impregnada de lembranças e significados, e "o sentimento da terra natal é mais forte quando, não apenas esta lhe é familiar, mas característica, constituída por certa singularidade [...]" "Ampliar e aprofundar nossa percepção do ambiente seria dar continuidade a um longo desenvolvimento biológico e cultural que avançou dos sentidos do tato para os sentidos distantes, e destes para as comunicações simbólicas" (LYNCH, 1997, p.5 e p.14). A isso, o autor atribui o nome de identidade, mas com o significado de individualidade.

A ponte entre o sonho e a realidade cotidiana é manifestada por diversos poetas, escritores, filósofos e artistas. Para o escritor Orhan Pamuk ${ }^{143}$, por exemplo, manter o segundo mundo em segredo (o do sonho) tornava mais fácil para ele o trânsito de um mundo - o do sonho - para o outro - o da realidade cotidiana. A título ilustrativo, vale destacar a reflexão do referido autor acerca de sua cidade natal, Istambul, em que ele tece uma rede de impressões subjetivas que conjuga sentimento, paisagem e memória. A narrativa ganha força à medida que o autor estabelece relações cognitivas com a arquitetura e a paisagem, expressando, por meio de vivências cotidianas, sentimentos do seu povo. O "sentir" torna-se a exata ilustração da paisagem, que, para ele, se traduz em melancolia, um sentimento de tristeza coletiva - a hüzun ${ }^{144}$-, nos signos impressos pela cidade. Um dos

143 PAMUK,Orhan. Istambul. Memória e Cidade.Tradução Sérgio Flaskman. São Paulo. Companhia das Letras, 2007.

144 Há uma grande afinidade entre "hüzun” e a outra forma de melancolia, a "tristesse”, descrita por Claude Lévi-Strauss em “Tristes Trópicos”, apesar de climas distintos entre as cidades tropicais e a de Istambul. Tanto a hüzun quanto a tristesse sugerem um sentimento compartilhado e comum a milhões de pessoas, mas as palavras e os sentimentos que descrevem não são idênticos. Na verdade, as cidades e as formas que a pobreza assume são semelhantes, tanto em Istambul quanto em Nova Délhi ou São Paulo. Para Pamuk, a diferença reside no fato de que, em Istambul, os restos de uma gloriosa civilização do passado são visíveis por toda a parte. A fragilidade da vida das pessoas, a maneira como tratam umas às outras e a distância que sentem dos centros do Ocidente fazem de Istambul uma cidade que os ocidentais recém-chegados têm grande dificuldade de compreender e, devido a essa incompreensão, 
centros dessa memória é o Edifício Pamuk, que se irradia por todas as direções da cidade, no tempo e no espaço. A narrativa extensa e rica em detalhes expressa a decadência e o cotidiano de sua cidade. A paisagem se completa na expressão do olhar sobre sua cidade natal, Istambul, e na intimidade cúmplice do seu interlocutor Pamuk:

\footnotetext{
[...] estou falando dos fins de tarde que o sol se põe mais cedo; das velhas barcas de passageiros do Bósforo amarradas em estações desertas no meio do inverno, com marinheiros sonolentos esfregando o convés; das casas de chá repletas até as vigas do teto de homens desempregados; das gangorras quebradas nas praças públicas; das muralhas da cidade em ruínas desde o fim do Império Bizantino; dos mercados que se esvaziam no fim da tarde; dos velhos e cansados Chevrolets dos anos 1950 que seriam peças de museu em qualquer cidade ocidental; [...] de ruínas de mármore que foram gloriosas fontes séculos a fio e agora estão secas; do homem que vende cartões-postais no mesmo ponto há quarenta anos; das cartas dos leitores, espremidas num canto do jornal e lidas por ninguém, anunciando que a cúpula da mesquita do bairro, construída há 375 anos, começou a ceder e perguntando por que o Estado não toma providências [...] ; das multidões de homens fumando cigarros depois do campeonato nacional, que durante a minha infância nunca deixavam de terminar em derrota adjeta: é deles todos que eu falo (PAMUK, 2007, pg. 104).
}

Num primeiro momento, a visualidade inerente à paisagem leva o pensamento a concentrar sua atenção em aspectos que apenas sugerem uma história ou um processo de formação social. Conforme argumenta Leite (1998, p. 56), “a visualização do que está apenas sugerido num primeiro momento, adquire corpo em cada um e no modo de reunião dos muitos objetos que constituem a paisagem. O pensamento movido pelo imaginário concentra sua atenção nos aspectos da realidade que devem ser transformados”. Segundo a autora, “esta atenção concentrada é a força motriz que permite à imaginação traduzir, em objetos simbólicos, os significados sociais implícitos na paisagem: é a visualidade da paisagem que permite a visibilidade das práticas sociais" (LEITE, 1998, p.56). Dessa forma, o observador tem um papel ativo na percepção do mundo e uma participação

atribuem a ela um "ar misterioso", identificando assim a hüzun com a tristesse de que fala Lévi- Strauss (PAMUK, 2007, p.110). 
criativa no desenvolvimento de uma determinada imagem.

Ao iniciar meus estudos sobre Anchieta, o que me ocorria, num primeiro momento, era me limitar ao presente, ou seja, centrar o foco no contexto das redes técnicas que estavam por se instalar, em vez de encarar o passado como uma voz autêntica da cidade. Porém, na medida em fazia incursões pela vila de Anchieta, por entre suas ruas, casas, visitava lagoas e adentrava os rios com barcos simples guiados pelos nativos que contavam inúmeras "estórias", gradativamente ia despertando em mim um grande interesse por descobrir a importância de uma época histórica. Nessa trajetória, incorporei o conhecimento dos sons e das falas, as sensações nitidamente carregadas de símbolos culturais que conferiam à cidade um ar de nostalgia e mistério. Anchieta guardava uma peculiaridade inusitada que se explicitava à medida que se conhecia suas paisagens e os seus segredos revelados por pessoas comuns. Tudo isso conferia uma autenticidade histórica e afetiva ao lugar.

Será esse o segredo de Anchieta - que, por detrás das suas edificações nada suntuosas voltadas para o rio e o mar, das paisagens tranquilas e sublimes, esconde uma teia frágil e elegante? Na simplicidade de seus moradores, uma cidade rica em gestos cotidianos? É possível perceber o pitoresco no silêncio das pequenas ruelas próximas ao porto com suas casas antigas degradadas, sugerindo uma história, assim como o pequeno porto com os inúmeros registros dos imigrantes italianos que por ali passaram e subiram o Benevente. A beleza que eu vejo no Santuário de Anchieta não é por nenhuma excepcionalidade de sua arquitetura religiosa, mas pela harmonia de sua composição: a praça; o conjunto igreja e residência; a vista da paisagem tanto para a baía do Benevente como também para o mar; a escadaria que liga o Santuário à baía, indicando um percurso do cotidiano jesuítico. Tudo isso forma um conjunto que, mesmo quatrocentos e cinquenta anos depois de sua construção, ainda se impõe na paisagem, como no primeiro momento.

Tanpinar, um grande romancista do século XX, para apresentar aquelas partes da cidade como áreas tradicionais que eram "arruinadas, pobres e infelizes", mas que "conservavam o seu estilo próprio, as tradições e o seu próprio modo de vida", recorria a palavras como "picturesque" e "paysa- 

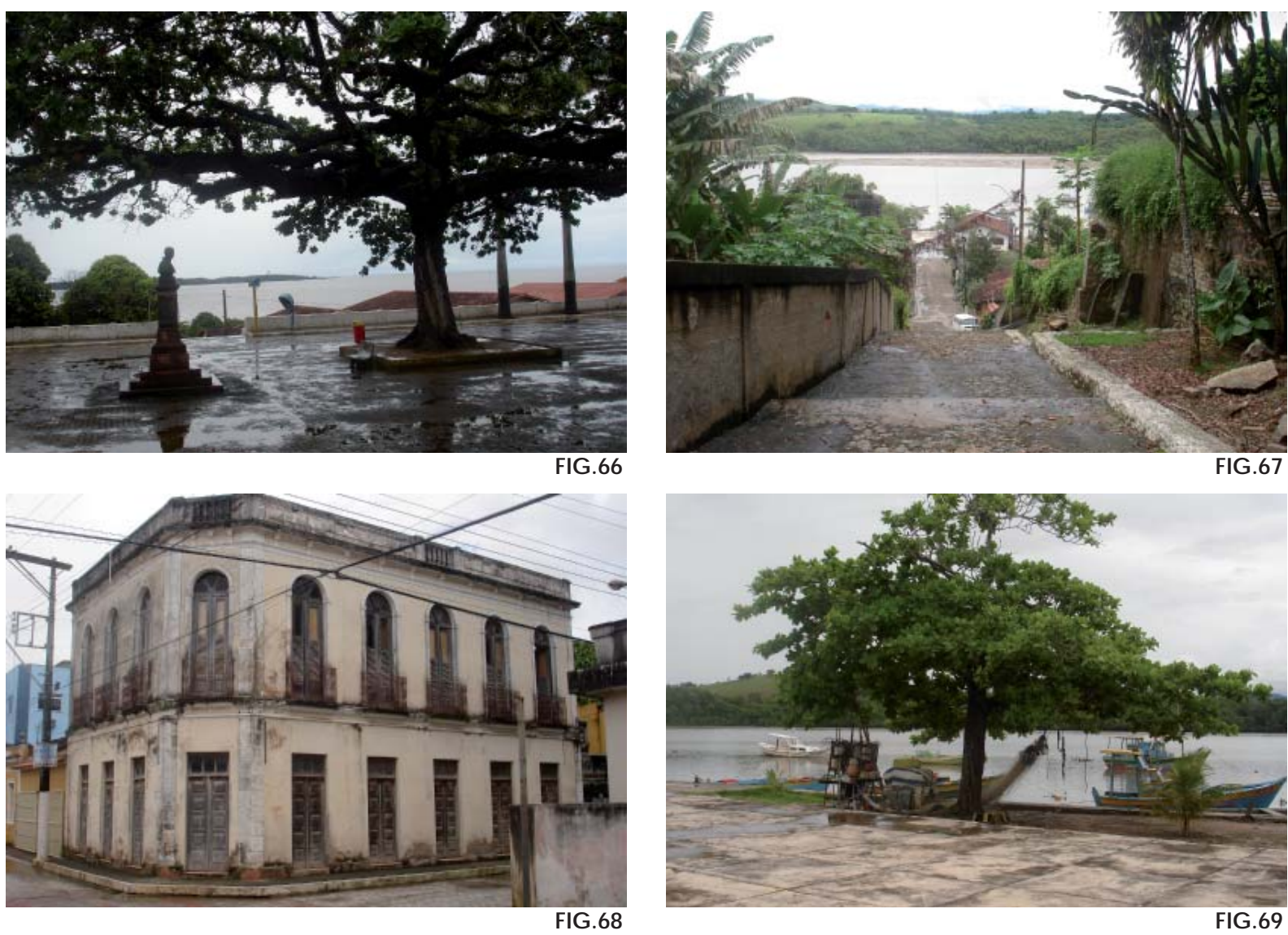

\section{PG.66}

Pátio do Santuário de Anchieta de onde se avista o mar. Fonte: Acervo pessoal.

PG.67

Escadaria junto ao Santuário que sugere o percurso dos jesuítas a té a baía do Rio Benevente. Fonte: Acervo pessoal.

FG.68

Casarão da família Assad na vila histórica de Anchieta. Fonte: Acervo pessoal.

FG.69

Atracadouro de barcos na baía do Benevente. Fonte: Acervo pessoal. ge". Já Walter Benjamin costumava dizer que as pessoas de fora de uma cidade são as que mais se interessam pelas suas características exóticas e pitorescas.

Mas, para descobrir a "alma" da cidade, para ver as ruínas como as do Rio Salinas, que suscitam mistérios e que manifestam a essência do lugar, é preciso recorrer a um longo caminho labiríntico de acidentes históricos, nem sempre explícitos. O tempo e os jogos de memória, que combinam tanto com as tradições do lugar, poderiam evocar a ilusão fugidia de que, pelo menos na qualidade do prazer estético, o passado ainda pudesse estar de alguma forma vivo. A partir dessa reflexão, passei a me sentir profundamente conectada à paisagem de Anchieta, porque ela me oferecia uma visão e uma compreensão mais profunda do que qualquer coisa que eu poderia aprender formalmente.

Entendemos melhor a paisagem em que nos movemos, quando aprendemos a reconhecê-la. A cada nova informação, a cada novo sobre a paisagem fazia com que eu adquirisse um olhar consciente da unicidade técnica 
a que estaria submetida a paisagem com a implantação do Polo, mas, ao mesmo tempo, me levava a uma interação poética com o lugar. As possíveis mudanças e manifestações locais dessa nova realidade que se impõe em Anchieta me fazem antever a dialética inerente ao movimento do espaço: a paisagem em constante transformação.

Ciente de todos os contextos e conceitos que regem a paisagem, ainda assim persiste a inquietação: Por que necessariamente deveria ter apenas a visão híbrida da paisagem de Anchieta? A "romântica" ou "nostálgica", como haviam suposto o meu olhar para com ela, não encontraria lugar? Será que já não é mais possível assegurar uma determinada imagem ou close que, no instante seguinte, já não o será mais, tão intenso é o movimento do espaço? Cobra-se, no mundo contemporâneo, para além de uma mudança de foco, a percepção em múltiplas e diversas escalas, ampliadas, procedimento que se costuma denominar de interação escalar. $\mathrm{O}$ olhar gerado pelas condições históricas que atualmente se apresentam no mundo é, constantemente, invadido por um olhar que não mais encontra a confiança tranquila que sempre se acostumou atribuir à paisagem. É um olhar que, cada vez mais, encontra como foco os objetos técnicos, fundamentalmente urbanos, os quais se tornam imperativos a outros olhares, sejam eles desiderativos, sejam nostálgicos.

A ideologia do mercado para justificar suas políticas de inserção no território, explicar o presente e esboçar o futuro, exime-se de qualquer realidade cotidiana em proveito de uma "realidade mais verdadeira e objetiva", que se dissimularia por trás de todas as coisas. Penso que a verdade vem sempre acompanhada de duplicidade, e que, a ambigüidade conduz o mundo; que não há o bem de um lado, e o mal do outro. O mundo como teia informacional e modo de organização não é o lugar onde reside a essência do homem. Talvez não seja apropriado aqui falar do homem ou da solidão que lhe é inerente, mas da paisagem, esta sim, continua sendo um dos únicos espaços no qual os homens pensam e poetizam, na medida em que se mantêm próximos ao ser.

Vale, então, retomar o pensamento de Hannah Arendt que nunca se distanciou dessa visão fundamental do mundo: "A eternidade é o que pensamos, mas é enquanto 'mortais' que [a] pensamos" (ARENDT apud ADLER, 


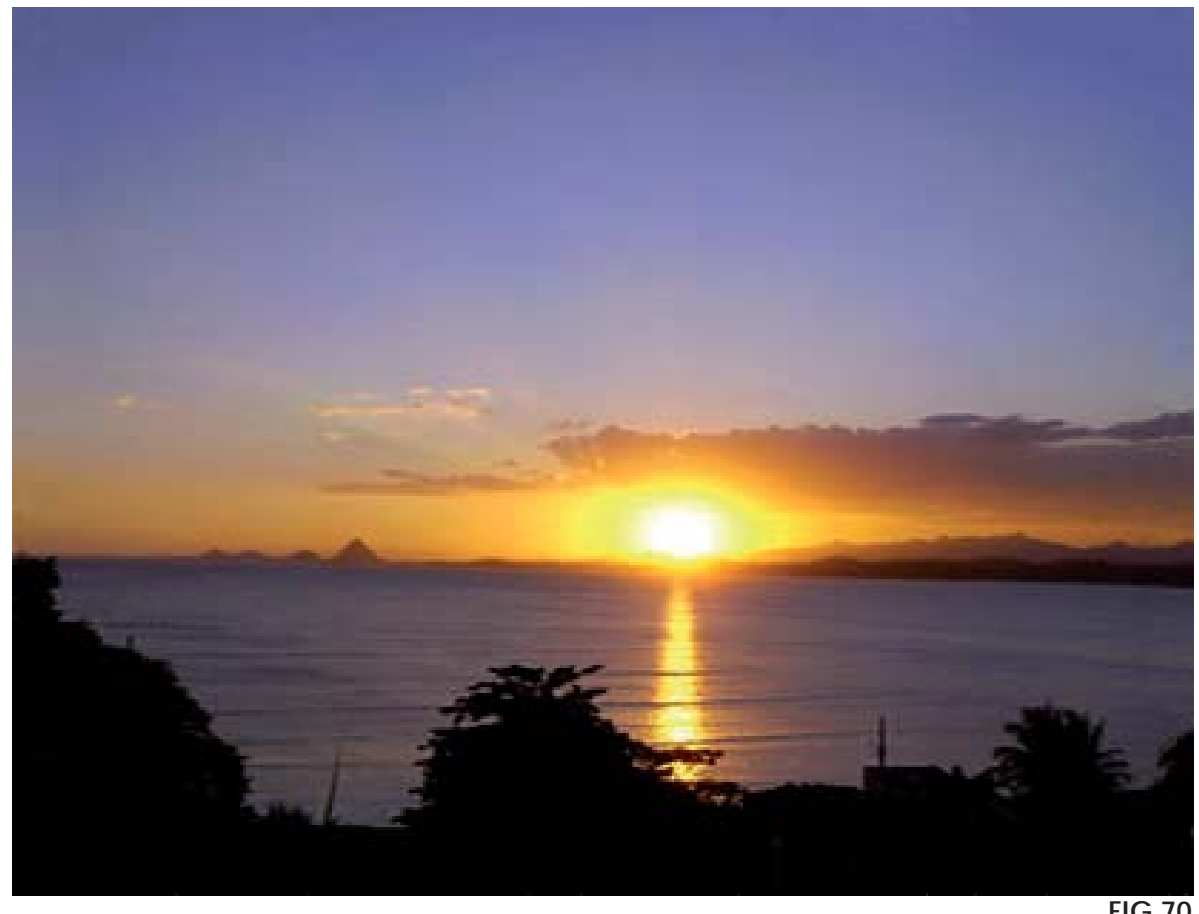

2007, p.377). Nosso pertencimento ao mundo consiste em saber que somos mortais e que tudo deverá prosseguir, apesar da revolução industrial e da bomba atômica. O mundo muda, mas não a condição fundamental da vida humana. O que interessa para Arendt é a maneira pela qual nos inserimos no mundo, nós todos enquanto espécie humana, e cada um de nós enquanto seres singulares e únicos. Cada um de nós é, pois, um criador que faz advir não apenas seu mundo, mas também o mundo: "Embora todos comecem a vida inserindo-se no mundo através do discurso e da ação, ninguém é autor ou criador de sua própria história"145. O que a autora quer dizer é que não temos nenhum domínio sobre o mundo, e, muito menos, sobre a nossa condição diante dele.

Com base no pensamento filosófico de Arendt, poderíamos afirmar que o desejo de perpetuação de uma paisagem é, no mínimo, em vão. Então, como não ser dela espectador? Não um mero espectador passivo, mas cúmplice. Uma cumplicidade que impõe restabelecer um sentido de cognição entre paisagem, lugar e imaginário. E nessa cumplicidade, o exercício da responsabilidade política e social para com ela. De qualquer modo, a esperança é que ainda perdure, sim, o olhar dos solitários, dos viajantes,

145 Pensamento de Hannah Arendt transcrito na entrevista concedida por HANS, Jonas. Souvenirs d'aprés des entretiens avec Rachel Salamander. Tradução: Sabine Cornille e Phillipe Irvinel, Payot Rivages, 2005, p.83. 
dos artistas e dos poetas sobre a paisagem.

A reflexão a respeito daquela imagem do pôr do sol levou-me à consciência do quanto era importante preservar certos momentos e paisagens no imaginário, assim como mantê-los. Não há como restringi-lo apenas ao registro frio e pretensamente objetivo daquilo que os olhos captam. No contexto atual, onde o mundo é um leque de inúmeras variáveis, o lugar - Anchieta - ainda mantém a força de poder ser apenas o lugar. E o que mais agrada em fazer essas incursões antropológicas ao lugar, é poder ver por toda a parte os vestígios de uma cultura que sofre a influência das redes mundiais de circulação e de consumo, sem ter perdido ainda sua originalidade ou vitalidade.

As imagens da paisagem de Anchieta, em especial a do pôr do sol, exercem sobre mim e, certamente, sobre os demais moradores do lugar o fascínio singular de reparação dessa cultura acelerada da vida moderna que nos cerca por todos os lados... Isso - a reflexão sobre o pôr do sol -, é o que, mais tarde, eu reconheceria como uma melancolia, enfim, uma fuga para aquilo que considero o vínculo substancial entre homem e natureza. A complexa rede de relações que assim se estabelece entre quem olha e o que se espera desse olhar, remete-nos para o sempre presente encanto e fulgor de um mundo que importa urgentemente (re)descobrir, um mundo em que todos os olhares se venham a tornar cúmplices de um mesmo comum desejo de humanidade. Um sentimento compartilhado por todos aqueles que, em seus depoimentos, ressaltaram a particularidade e a quietude inspiradora da paisagem de Anchieta. 

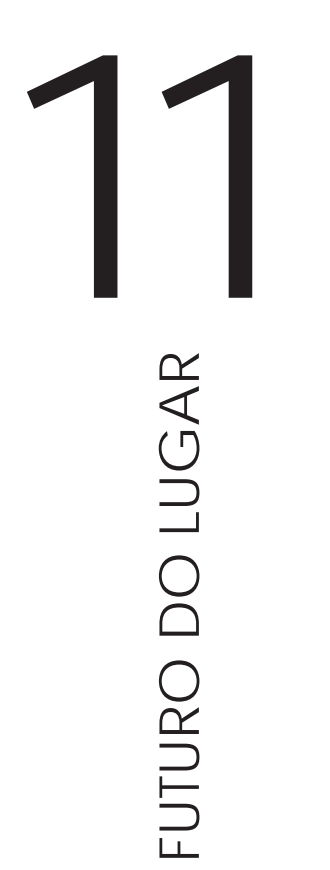

0

A política agora é feita no mercado. Só que esse mercado global não existe como ator, mas como uma ideologia, um símbolo. Os atores são as empresas globais, que não têm preocupações nem éticas, nem finalísticas. Dir-se-á que, no mundo da competitividade, ou se é cada vez mais individualista, ou se desaparece. Então, a própria lógica de sobrevivência da empresa global sugere que funcione sem nenhum altruísmo. Mas, se o Estado não pode ser solidário e a empresa não pode ser altruísta, a sociedade como um todo não tem quem a valha.

Santos (2006) 
316| CAPÍTULO 11 


\section{CONSIDERAÇÕES RNAIS: O FUTURO DO LUGAR}

Valorizar grandes questões e desafios, que iluminam e justificam projetos de longo prazo, não é incompatível com a valorização de pequenas (ou cotidianas) questões e pequenos desafios, os quais dão sentido agora e atualizam criticamente o navegar de longo curso, desde que as duas coisas sejam sempre bem articuladas. As escolhas que estão sendo feitas não podem ser explicadas a partir de uma lógica tecnológica ou estritamente econômica como afirma o discurso neoliberal adotado no Plano 2025, mais especificamente na condução das questões relativas ao Polo Anchieta. Em geral, os projetos pautados pelo viés econômico e vinculados às estratégias das redes globais nunca são capazes de poupar o local vitimado pela escolha. As técnicas, em todos os seus domínios, exigem autorizações para serem implantadas. As escolhas são políticas pelo fato de refletirem os interesses de alguns grupos sociais, mais especificamente os dos grandes empreendedores privados, que impõem sua hegemonia por meio da implementação desse sistema de redes globais.

As estatísticas e os dados falam, muitas vezes, da aceleração do crescimento de uma dada região, na tentativa de mostrar que as chamadas desigualdades regionais estão se atenuando. É possível que um olhar simplório sobre os dados possa induzir o leitor, e mesmo o especialista, a essa conclusão. O problema, todavia, não é o de medir quantidades, mas de verificar o que significam. As mais das vezes, os projetos pouco representam para a economia da área em que se inserem, mas contribuem para aumentar exponencialmente lucros dos grandes empreendedores e servem aos interesses do mercado externo. O problema principal do Polo Anchieta é que nenhuma questão pode ser respondida fora da concepção de uma totalidade de estruturas e de uma totalidade de relações que se estabelecem em todas as dimensões, seja econômica, ambiental, seja social. Não há, portanto, desenvolvimento, se algumas dessas dimensões não se sustentam ou ficam a reboque das demais.

Conforme se procurou demonstrar ao longo da tese, percebe-se de imediato que a questão do Polo Industrial, antes de estar imbuída de uma preocupação social e paisagística do lugar que serve de instrumento para 
acomodá-lo, revela-se mais pelas prioridades econômicas e políticas respaldadas por atos jurídicos que levam à perda dos valores socioambientais. O complexo mínero-siderúrgico do Polo Anchieta poderá representar divisas para o Espírito Santo. Entretanto, o argumento que permeia todo o suposto desenvolvimento da região é ceifado pela própria contradição inerente ao seu discurso, ou seja, a possibilidade quase irrefutável da fragmentação de áreas ambientalmente sensíveis, a inadequação da infraestrutura e equipamentos sociais para atendimento às demandas do Pólo e comprometimento da base social e cotidiana das populações tradicionais.

A reflexão sobre o quadro nos leva a prever o conflito iminente entre a atividade industrial e a necessidade de banir e/ou controlar com rigor sua expansão em áreas de interesse ambiental. À exuberância da paisagem associa-se a diversidade histórico-cultural. Os estudos apontam e a experiência mostra que todo esse potencial estaria sendo ameaçado. A redução do território à sua dimensão estritamente material do ponto de vista economicista tende a afetar a complexidade da trama social responsável pela inovação da temporalidade histórica das cidades.

O discurso que embasa o Polo Industrial como instrumento de aceleração econômica é incompatível com as práticas pretendidas de preservação do patrimônio cultural e ambiental e o desenvolvimento social em todos os seus aspectos, mesmo considerando que as mesmas leis que criaram o Polo embasaram os critérios de proteção. A possibilidade de vislumbrar os resultados concretos num futuro próximo é vaga ou imprecisa quanto às prioridades estabelecidas pelos planos que asseguram e regulam a implantação do Polo Anchieta. A relativa autonomia do lugar, nesse processo, é substituída por crescente interdependência "funcional" em relação à atividade produtiva.

Como vimos, Anchieta apresenta especificidades ecossistêmicas diversas que compõem a paisagem. A falta de informações básicas sistematizadas não favorece a tomada de decisões quanto à locação de empreendimentos e na formulação de uma gestão ambiental eficaz. A ausência de Planos de Manejo e de conselhos gestores das Unidades de Conservação (UC’s) e a ausência de monitoramento público sistemático dos lançamentos de esgoto doméstico, hospitalar e industrial são outros dos fatores que dificultam 
a manutenção de importantes ecossistemas presentes no município. Além disso, faltam mecanismos eficazes para impedir a ocupação das áreas ciliares dos corpos d'água e topos de morros e manter áreas para recarga dos aquíferos, para fiscalizar o desmatamento e efetivar a recomposição ciliar. Todas essas variáveis negativas aliadas à imprevisibilidade dos fatos gera um descontrole das áreas ambientalmente sensíveis como um todo. Tal situação não favorece o planejamento das intervenções na busca / melhoria da qualidade ambiental.

Tendo por base essas premissas, não há razões para se esperar que aconteça uma compatibilização ou acomodação tranquila entre as zonas, ambiental e industrial, nos moldes estabelecidos e previstos no PDM de Anchieta. O discurso do planejamento organiza-se, neste caso, pelo recurso à condição de "resiliência", ou seja, aquele que procura descrever a capacidade dos ecossistemas para superarem a sua condição de vulnerabilidade a choques externos. Há, portanto, uma clara divergência entre os interesses corporativos e as regras da legislação de proteção ambiental que restringem as atividades econômicas no entorno dessas áreas ambientalmente frágeis. Onde haverá convergência das prospostas, por ora, está difícil vislumbrar.

De qualquer modo, é importante, neste momento, fazer uma avaliação propositiva para ajustes das áreas delimitadas no PDM como Zona de Expansão Industrial 1 - ZEI 1, situadas nas proximidades do Rio Benevente e da Estação Ecológica do Papagaio, onde uma alteração do zoneamento deve ser levada a efeito. Tal proposta é justificada considerando que o Polo Industrial e de Serviços de Anchieta prevê a reserva de áreas para fins de ampliação no entorno da Estação do Papagaio e APP do Rio Benevente, propondo ainda viabilizar a implantação de um parque na área das Ruínas do Rio Salinas. Da mesma forma, para a área delimitada no PDM como Área Especial de Interesse Ambiental 2, situada entre o Monte Urubu e o Rio Benevente, propõe-se que ela seja alterada no zoneamento, considerando a proposta de funcionalidade do Polo Industrial e de Serviços de Anchieta, além de inclusão da possibilidade de ampliação das Áreas Especiais de Interesse Ambiental.

Entre as conclusões a que os estudos chegaram, está a indicação de que, mantidos os atuais padrões de densidade, os municípios terão problemas 
na absorção do incremento populacional previsto, uma vez que exigirá a abertura de novas áreas para a urbanização, com custos proporcionais às densidades previstas. $\mathrm{O}$ conflito entre o crescimento demográfico e a ocupação de áreas tidas como de preservação ambiental é iminente. Mais que isso, a verificação dos cenários disponíveis hoje para a convivência entre densidade populacional, siderurgia e demanda por água pode levar a uma construção insustentável do espaço regional. Por outro lado, não há nenhum sinal de que o início de uma curva descendente da desigualdade regional e intraurbana se verifique com a implantação do Polo. A verticalidade de um fenômeno dito global não implica haver nenhuma automaticidade no sistema que o leve a redistribuir na escala das horizontalidades (cotidiano).

Considerando a formatação do Polo Industrial de Anchieta em sua concepção, observa-se que além do aspecto da vulnerabilidade ambiental já mencionado, não há uma preocupação que enfatize a noção de lugar como processo histórico e de construção de identidades. No atual Plano Diretor Municipal (2006) e na Avaliação Ambiental Estratégica (2008), em que pesem todos os reveses embutidos na negociação das propostas, os estudos de capacidade de suporte da infra-estrutura podem ser identificados; porém, eles apontam na direção da insuficiência em compatibilizar demandas provenientes de objetos técnicos de magnitude em virtude do previsível crescimento demográfico nas cidades. Assim como, é evidente a inexistência de parâmetros seguros que apontem para a regulação e capacidade de suporte das águas perante o aumento da atividade industrial. Essas são apenas algumas, entre outras premissas básicas a serem observadas, a que a noção de "sustentabilidade" incorporada ao planejamento deveria se ater para não cair na reprodução corriqueira do discurso que lhe é inerente.

Cada vez mais as políticas são globalizadas e o âmbito de decisão da esfera local é reduzido, que se justifica em parte, pelas dificuldades encontradas no confronto entre o poder e a sociedade; por isso onde os resultados esperados não refletem as aspirações coletivas. Outro aspecto a ser realçado é que a intenção do Plano 2025 de fazer com que novas centralidades regionais despontem no cenário estadual ainda é incipiente e configura-se mais como uma proposta virtual do que concreta propriamente dita. Os investimentos continuam concentrados e direcionados para o entorno da 
Região Metropolitana e em seu entorno imediato, na costa litorânea dos municípios adjacentes.

A lógica da ocupação do espaço urbano que, de modo geral, favorece os grandes grupos econômicos e parcelas restritas da população, somada à distribuição seletiva das infraestruturas e dos equipamentos urbanos, induz ao crescimento das periferias urbanas e das diferenças regionais, à melhor expressão da segregação sócio-espacial a que são submetidas partes das cidades e a grande maioria de seus habitantes. Tal qual acontece na "Região Concentrada", podemos dizer que a absorção do meio "técnicocientífico-informacional" no território capixaba se dá como refluxo do processo de concentração na Região Metropolitana da Grande Vitória, especificamente em polos adjacentes a ela (litoral sul - Anchieta - e litoral norte - Linhares), e se desenvolve ainda de forma frágil e periférica, impedindo que estes pólos possam concorrer na constituição efetiva de uma nova centralidade.

A questão ambiental incorpora a complexidade das questões de cunho social e cultural, em especial nas situações particulares em que a população está inserida no ambiente a ser preservado. Nesse sentido, é preciso dotar os cidadãos de condições mínimas para o exercício de sua cidadania, já que a responsabilidade da gestão deve ser dividida entre Estado, municípios e sociedade civil. Mesmo considerando o diferencial relativo à criação sistemática de regulamentações da legislação ambiental brasileira em suas diversas instâncias, observa-se que, na prática espacial, a esfera do econômico ainda é preponderante em detrimento da esfera ambiental e social. Quanto aos mecanismos de processos participativos, estes estão muito aquém de representatividade nos fóruns e conselhos.

É inegável o poder de barganha dos lugares, conferido pelo próprio fato de abrigarem os investimentos técnicos e financeiros, o que permitiria a negociação de contrapartidas, por parte do poder público local e estadual, junto às empresas. Contudo, o que se observa é que o capital produtivo mundial retira boa parte de sua força de penetração nos lugares, de sua capacidade de enfraquecer os atores sociais menos móveis - governos locais e movimentos sindicais ou comunitários, por exemplo - desfazendo normas governamentais urbanas ou ambientais. Por sua maior mobilidade, 
o capital mundial especializa gradualmente os espaços, produzindo uma crescente coincidência entre a localização de áreas degradadas e dotadas de menor capacidade de organização técnica dos seus recursos e de menor resistência dos atores locais. Configura-se assim uma espécie de divisão social do espaço, definida pelo que, poderíamos chamar, de especialização técnica do poder.

É preciso que os lugares e a sociedade percebam que, ao abrigarem um grande investimento privado e ao ter seu espaço cotidiano todo reorganizado para melhor servir a demandas específicas, os lugares passam a ter uma expressiva vantagem de negociação com as empresas. Parte da responsabilidade cabe ao poder público, em todas as suas esferas, o qual se esforça para planejar e disponibilizar o uso do seu território para as grandes empresas; no entanto, por outro lado, muitas vezes, as dinâmicas e particularidades das regiões e lugares que preenchem esse mesmo território não são consideradas numa dimensão mais ampla. De uma forma ou de outra, constata-se que novos campos de força atuam sobre o Estado, e este não tem, necessariamente, o poder de ingerência ou de investidor principal, senão o poder de assumir a coordenação de macroestratégias.

Não se tem aqui, a intenção de rotular o desenvolvimento econômico como algo perverso e de considerar que as cidades e respectivas paisagens devam permanecer intocáveis, mas deve se pensar no Polo Industrial como uma alternativa real para atrair investimentos, gerar empregos e renovar a base produtiva local. É importante pensar na aplicação de políticas públicas integradas que assegurem a permanência dos moradores no local e a gestão comunitária do processo, em parceria com as esferas públicas e privadas, para um efetivo desenvolvimento social e controle sobre os seus lugares de vida.

Em outras palavras, a questão parece residir mais na necessidade de uma estratégia institucional, aliada à capacitação da participação popular visando a um esforço conjunto capaz de considerar e valorizar as aspirações coletivas e exercendo um controle social mais eficaz sobre as políticas globais na utilização dos espaços e recursos disponíveis. Esse talvez seja o ponto de partida para se pensar a responsabilidade institucional na regulação tanto da proteção como do aproveitamento econômico e social das 
paisagens e do lugar. Para tanto, é imprescindível manter a autonomia de suas organizações, construindo alternativas viáveis para um desenvolvimento mais equitativo. Caso contrário, a sociedade e o Estado deixar-seiam envolver na teia de projetos econômico-sociais que beneficiam reduzido número de pessoas.

A sociedade civil não pode assumir responsabilidades que são do Estado, mas sim, compete a ela exercer uma função política sobre o Estado no sentido de que este possa priorizar as necessidades do conjunto da sociedade. Nessa perspectiva, importante realçar o papel atribuído ao Estado de regulação do território, substituindo o enfoque mecanicista e restritivo do planejamento por um enfoque mais proativo, que se apoie em um conhecimento mais aprofundado do território e das especificidades de sua cultura. A ruptura da dicotomia "natureza-cidade" é pressuposto básico para esse novo olhar, de modo a permitir que a cidade e seus habitantes reconheçam os valores inerentes ao seu território, modificado pela ação do homem, criando uma nova consciência, com respeito ao que consideram como recursos valiosos e significativos. 
324| CAPÍTULO 11 


\section{REERÊNCIAS}

ABE, André. Grande Vitória, ES: crescimento e metropolização.Tese de Doutorado - Faculdade de Arquitetura e Urbanismo, Universidade de São Paulo, São Paulo,1999.

ACSELRAD, Henri. Discursos da sustentabilidade urbana. Revista Brasileira de Estudos Urbanos e Regionais, n.1, ANPUR, p. 1-14, 1999.

ACSELRAD, Henri; HERCULANO, Selene; PÁDUA; José Augusto. Justiça ambiental e cidadania. Rio de Janeiro: Relume Dumará. Fundação Ford, 2004.

ADLER, Laure. Nos passos de Hannah Arendt. Tradução Tatiana Salem Levy e Marcelo Jacques. 3. ed. Rio de Janeiro: Record. 2007.

AGNEW, John. From the political economy of regions to regional political economy. Progress.Human Geography, v. 24, n. 1, p.101-110, 2000.

APPADURAI, Arjun. Modernity at Large: Cultural Dimensions of Globalization. Public Worlds. Vol.1, Minneapolis: University of Minnesota Press, 1996

APPURBANA2007. Resumos expandidos e programa de seminário nacional sobre o tratamento de áreas de preservação permanente em meio urbano e restrições ambientais ao parcelamento do solo. São Paulo: Faculdade de Arquitetura e Urbanismo, Universidade de São Paulo, 2007.

ARACRUZ CELULOSE S.A. Formação do pólo industrial de AracruzInfra-estrutura básica. 1977. Relatório.

ARAÚJO FILHO, José Ribeiro. O Porto de Vitória. São Paulo: Ed. Gráfica Cairu 1974.

ARENDT, Hannah (1958). A condição humana. Tradução: Roberto Raposo, 5. ed. Rio de Janeiro: Forense Universitária, 1991.

ARRAIS, Tadeu Alencar. A cidade e a região/a cidade-região: reconhecer processos, construir políticas. Cadernos Metrópole, São Paulo, n.20, p.8191, $2^{\text {a }}$ sem. 2008.

AUGÉ, Marc. Não-Lugares: introdução a uma antropologia da supermodernidade. 4. ed. Campinas: Papirus, 2004. 
BARBIER, E. The concept of sustainable economic development. Environmental Conservation, v.2, n.14, p.101-110,1987.

BARBOSA, Isabella B. Muniz. Modernidade e assimetrias na paisagem: a fragmentação de ecossistemas naturais e humanos na Baía Noroeste de Vitória - ES. 2005. Dissertação de Mestrado - Faculdade de Arquitetura e Urbanismo, Universidade de São Paulo, São Paulo, 2005.

BARIDON, Michel. Paisaje con un filósofo, un geógrafo y un historiador. In: BERJMAN, Sonia (org.). Diversas maneras de mirar el paisaje. Buenos Aires: Nobuko, p. 11-25, 2005.

BAUDRILLARD, Jean. Simulacros e simulações. Lisboa: Relógio D’Agua, Ed., 1991.

BENJAMIN, Walter. Charles Baudelaire: um lírico no auge do capitalismo. Trad. José carlos Martins Barbosa e Hemerson Alves Baptista.São Paulo: Brasiliense, Obras escolhidas, v. 3, 1989.

BERARDINELLI, Cleonice (org.). Fernando Pessoa Poemas. 6. ed. Rio de Janeiro: Nova Fronteira, 1985, 162 p.

BERMAN, Marshall. Tudo que é sólido desmancha no ar - a aventura da modernidade. São Paulo: Companhia das Letras, 1987.

BERQUE, Augustin. La trajectivité des formes urbaines. In: SALGUEIRO, Heliana Angotti (org.). Paisagem e arte: a invenção da natureza, a evolução do olhar. Anais do I COLÓQUIO INTERNACIONAL DE HISTÓRIA DA ARTE . São Paulo, 2000, p. 41-47.

BECKER, Bertha. A geopolítica na virada do milênio. Logística e desenvolvimento sustentável. In: Castro. I.E. et al. (Orgs.). Redescobrindo o Brasil. Rio de Janeiro: Bertrand Brasil, 1999.

BESSE, Jean-Marc. Ver a Terra - seis ensaios sobre a paisagem e a geografia. Tradução Vladimir Bartalini. Arles: Actes Sud / ENSP / Centre du paisaje, 2000.

BRANCO, Samuel Murgel. 1995. Conflitos conceituais nos estudos sobre meio ambiente . Estudos Avançados, São Paulo: IEA,/USP, n.9, p.217233,1995.

BRANCO, Samuel Murgel \& ROCHA, Aristides Almeida. Ecologia, educação ambiental: ciências do ambiente para universitários. São Paulo: CETESB. 1987. 
BRASIL - PAC, 2008. Disponível em: < htttp://www.brasil.gov.br/PAC/ estados>.Acesso em:10 ago 2010.

BRASIL. Ministério da Integração Nacional. Anais da I MOSTRA NACIONAL DE DESENVOLVIMENTO REGIONAL. Salvador. Março 2009, Salvador: Ministério da Integração Nacional, 2009.

Para pensar uma política de ordenamento territorial. Anais da OFICINA SOBRE A POLÍTICA NACIONAL DE ORDENAMENTO TERRITORIAL. Brasília: Ministério da Integração Nacional, 2005.

BREITBACH, Áurea.C.M. Estudo sobre o conceito de região. Porto Alegre: Fundação de Economia e Estatística Siegfried Emanuel Heuser, 1988. 96p. (Teses,13).

BRUNET, Roger et al. Les mots de la Géographie. Dictionnaire critique. Paris, Montpellier : La Documentation Française. Reclus., 1990.

BRUNHES, Jean (1910). La Geógraphie Humaine: Essay de classification positive, principes et exemples. 2ème. ed. Paris: Félix Alcan, 1912.

CAMPOS JÚNIOR, Carlos Teixeira. O novo arrabalde: aspectos da formação urbana de Vitória. Dissertação (Mestrado) - Faculdade de Arquitetura e Urbanismo da Universidade de São Paulo. São Paulo, 1985.

A construção da cidade: formas de produção imobiliária em Vitória. Vitória: Flor e Cultura, 2002.

CARLOS, Ana Fani Alessandri. O lugar no/do mundo. São Paulo: Hucitec, 1996.

CASTELLS, Manuel - La question urbana. 2. ed. Madrid: Siglo Veinteuno,1976.

A intervenção Administrativa nos Grandes Centros Urbanos. Espaço \& Debates, São Paulo: Cortez, n.6, p. 64, 1982.

CASTELLS, Manuel; MURPHY, Karen. Cultural identity and urban structure: the spatial organization of San Francisco's Gay Community. Urban affairs annual reviews, v. 22, p. 1-20,1982.

CASTORIADIS, Cornelius. A Instituição imaginária da sociedade. Rio de Janeiro: Paz e Terra, 1982.

CLAVAL. Paul. A contribuição francesa ao desenvolvimento da abordagem cultural na geografia. In: CORREA, Roberto Lobato e ROSENDHAL, 
Zeny (org.). Introdução à geografia cultural. Rio de Janeiro: Bertrand, 2007 , p.41-47.

O território na transição da Pós-modernidade. Revista géographies et cultures.Tradução e revisão de: Inah Vieira Lontra, Márcio de Oliveira e Rogério Haesbaert. Universidade de Sorbonne. Paris: L'Harmattan, n. 20, 1996.

COLBY, Michael Ellsworth. Environmental management in development: the evolution of paradigms. World bank discussion. Paper. 1990.

COSTA, Heloisa Soares de Moura. Desenvolvimento Urbano Sustentável: uma contradição em termos? Revista Brasileira de Estudos Urbanos e Regionais, ANPUR, n.2, p.55-71, mar.2000.

CROCCO, Marco. Redes e polarização urbana e financeira: uma exploração inicial para o Brasil. Belo Horizonte: UFMG/Cedeplar, 2008.

CST. Estudo de viabilidade. Relatório final. Vitória: CST, 1974.

Companhia Siderúrgica de Tubarão. Estudo de impacto ambiental - EIA/RIMA “ALTO FORNO I”. Vitória: CEPEMAR, 1996. $4 \mathrm{~V}$.

CURBANI, Sáira Glazar. Henrique Novaes em diferentes momentos: Plano Geral da Cidade de 1917 e Plano de Urbanização de Vitória de 1931. Vitória: Universidade Federal do Espírito Santo, 1998.

DARDEL, Eric (1952). L' Home et la terre. Paris: CTHS, 1990.

DEÁK, Csaba (1985). O mercado e o Estado na organização espacial da produção capitalista. Espaço \& Debates, n. 28, p.18-31, 1989.

DEBÓRD, Guy. A sociedade do espetáculo. Rio de Janeiro: Contraponto, 1997.

EMBRAPA. Sistema Brasileiro de Classificação de Solo. Brasília: Embrapa Produção de Informação; Rio de Janeiro: Embrapa Solos, 1999.

ESCOBAR, A. Encountering development: the making and unmaking of the third world. Princeton: Princeton University Press, 1995.

ESPAÇO CONSTRUTORA. Estudos para formulação do PLANO DIRETOR MUNICIPAL DE ANCHIETA. Vitória, 2006.

ESPÍRITO SANTO EM AÇÃO. Avaliação Ambiental Estratégica do 
Pólo Industrial e de Serviços de Anchieta - ES.Vitória, 2008.

ESPÍRITO SANTO (estado). Decreto n ${ }^{\circ}$ 1.499-R, de 14 de junho de 2005. Dispõe sobre espécies da fauna e flora ameaçadas de extinção no Estado do Espírito Santo. Diário Oficial do Estado do Espírito Santo, p. 4, 14 jun. 2005.

ESPÍRITO SANTO (estado). Decreto Estadual $\mathrm{n}^{\circ} 1.247-\mathrm{S}$, de 10 de julho 2007. Diário Oficial do Estado do Espírito Santo, p.6, 11 jul. 2007.

ESPÍRITO SANTO (estado). Secretaria de Estado de Economia e Planejamento. Espírito Santo 2025: Plano de Desenvolvimento.Vitória-ES, 2006.

Instituto de Apoio à Pesquisa e ao Desenvolvimento Jones dos Santos Neves (IJSN). Região Metropolitana da Grande Vitória - RMGV: Sistema Gestor e informações Básicas. Vitória: IJSN, 2005.

Instituto de Apoio à Pesquisa e ao Desenvolvimento Jones dos Santos Neves (IJSN). Verticalização e reestruturação urbana na Região Metropolitana da Grande Vitória:1990-2002.Vitória-ES: IJSN, 2006.

Instituto de Apoio à Pesquisa e ao Desenvolvimento Jones dos Santos Neves (IJSN). Região Metropolitana da Grande Vitória. Vitória: IJSN, 2006.

Instituto de Apoio à Pesquisa e ao Desenvolvimento Jones dos Santos Neves (IJSN). Investimentos previstos 2007-2012. Vitória, IJSN, 2008.

Instituto de Apoio à Pesquisa e ao Desenvolvimento Jones dos Santos Neves (IJSN). Estatísticas de Comércio Exterior 2005: Portos do Espírito Santo. Vitória: IJSN, 2006.

Instituto de Apoio à Pesquisa e ao Desenvolvimento Jones dos Santos Neves (IJSN). Perfil básico de Anchieta. Vitória: IJSN, 2008.

FERNANDES, A.J. \& PERIA, L.C.S. Características do ambiente. In: SHAEFFER-NOVELLI, Y. (Coord.) Manguezal: ecossistema entre a terra e o mar. São Paulo: Caribbean Ecological Research. 1995, p. 13-15.

FERNANDES, Rubem César. Privado, porém, público: o terceiro setor na América Latina. Rio de Janeiro: Relume-Dumará, 1994.

FERRARA, Lucrécia d'Alessio. Os significados urbanos. São Paulo: Editora da Universidade de São Paulo: Fapesp, 2000. 
. Os lugares improváveis. In: YÁZIGI, Eduardo (org). Turismo e paisagem. São Paulo: Contexto, 2002.

FERREIRA, William Rodrigues. O espaço público nas áreas centrais: a rua como referência - um estudo de caso em Uberlândia-MG. Tese (Doutorado) - Faculdade de Filosofia, Letras e Ciências Humanas, Universidade de São Paulo, São Paulo, 2002.

FORMAN, R.; GODRON, M. Landscape ecology. New York: John Wiley, 1986.

FOUCAULT, Michel. Afterword. The Subject and Power. In: DREYFUSS, Hubert L. and RABINOW, Paul (org.) Michel Foucault - beyond structuralism and hermeneutics. $2{ }^{\text {nd }}$. ed. Chicago: The University of Chicago Press.,1983, p. 208-226.

.What is enlightenment? In: RABINOW, Paul (Ed.). The Foucault reader. New York: Pantheon Books, 1984.

.The art of telling the truth. In: KELLY, Michael (Ed.) Critique and power: recasting the Foucault/ Habermas debate. Cambridge: MIT Press, 1994.

. Microfísica do poder. Rio de Janeiro: Graal,1998.

FRUGOLI JÚNIOR, Heitor. Centralidade em São Paulo: trajetórias, conflitos e negociações na metrópole. São Paulo: Cortez; Editora da Universidade de São Paulo, 2000.

. São Paulo: espaços públicos e interação social. São Paulo: Marco Zero, 1995.

FURTADO, Celso (1974). O mito do desenvolvimento econômico. 4.ed. Rio de Janeiro: Paz e Terra, 1996.

Em busca de um novo modelo. Rio de Janeiro: Paz e Terra. 2005.

GIDDENS, A. As conseqüências da modernidade. São Paulo: Universidade Estadual Paulista, 1991.

GODARD, Olivier. Environnement, modes de coodination et sistèmes de legitimé: analyse de la categorie de patrimonie naturel. Révue Economique. Paris, n.2, 1990.

GOTTMANN, JEAN. (1952): La politique des États et leur géographie. Paris: A. Colin, 1973. 
The significance of territory. Charlottesville: The University Press of Virginia. 1973.169 p.

HABERMAS, Jürgen. Mudança estrutural da esfera publica: investigações quanto a uma categoria da sociedade burguesa. Tradução de Flávio R.Kothe. Rio de Janeiro: Tempo Brasileiro, 2003.

HAESBAERT, Rogério. Desterritorialização, multiterritorialidade e regionalização. In: Para pensar uma política nacional de ordenamento territorial. Anais da OFICINA SOBRE A POLÍTICA DE ORDENAMENTO TERRITORIAL. Brasília, Ministério da Integração Nacional, 2005.

Desterritorialização: entre as redes e os aglomerados de exclusão. In: Castro, I. et al. (orgs). Geografia: conceitos e temas. Rio de Janeiro: Bertrand Brasil, 1995.

Da desterritorialização à multiterritorialidade. In: IX Encontro Nacional da ANPUR. Anais...Vol. 3. Rio de Janeiro: ANPUR, 2001.

. Fim dos territórios ou novas territorialidades? In: LOPES, L.: BASTOS, L. (orgs.). Identidades: recortes multi e interdisciplinares. Campinas: Mercado de Letras, 2002.

HARVEY, David. Condição pós-moderna. 9. ed. São Paulo: Loyola, 2000.

HELlER, Agnes. O cotidiano e a história. 8 ed. Rio de Janeiro: Paz e Terra, 2008.

HOUGH, Michael. City form and natural processes. New York: Routledge, 1989.

JAMESON, Frederick. Pós-modernismo: a lógica cultural do capitalismo tardio. São Paulo: Ática, 1996.

JOLY, Carolina. Especialização produtiva do território e o circuito espacial produtivo de celulose em Eunápolis - BA. Dissertação (Mestrado) - Faculdade de Filosofia, Letras e Ciências Humanas da Universidade de São Paulo. São Paulo, 2007.

KAYSER, Bernard. (1980). A região como objeto de estudo da geografia. In: GEORGE, Pierre et al. Geografia ativa. São Paulo: Difel, 1980.

LACOSTE, Yves. Para que serve a paisagem? O que é uma bela paisagem? Tradução Luís Antônio Venturi. Bol. Paul. Geog., São Paulo, n. 79, p.115150, 2003. 
LATOUR. Jamais fomos Modernos. São Paulo: Editora 34. 2000.

LEFEBVRE, Henri. La Production de l'espace. 3 . $^{\text {ime }}$ ed. Tradução Jorge Oseki. Paris : Anthropos, 1986.Cap.VI.

Le materialisme dialetique. Paris. Quadrige/PUF.1940.

De l'État : Le mode de production étatique. Tradução Jorge Oseki (mimeo). Tomo III, cap.1,2,3 e 4. Paris, 1977.

Espacio y política. Barcelona: Ediciones Península, 1976. 159 p.

LEITE, Maria Ângela Faggin Pereira (1994). Destruição ou desconstrução? Questões de paisagem e tendências de regionalização. 2.ed. São Paulo: FAPESP: Hucitec, 2006.

As tramas da segregação. Tese (Livre Docência) - Faculdade de Arquitetura e Urbanismo da Universidade de São Paulo. São Paulo, 1998.

Natureza e Cultura: paisagem, objetos e imagens. Paisagem e ambiente: ensaios/ Universidade de São Paulo, Faculdade de Arquitetura e Urbanismo, São Paulo, n.18, p.59-69, 2004a. Anual. ISSN 0104-6098.

- Mas se o lugar nos engana, é por conta do mundo. In: BRANDÃO, Maria (org.). Milton Santos e o Brasil. São Paulo: Fundação Perseu Abramo, 2004b, p. 51-56. ISBN: 8586469998.

LIMA, Thiago Muniz. Genealogia do Poder: In: Zaganelli Margareth (org.). Estudos de História do Processo. Rio de Janeiro: Editora Lúmen, 2009. p.213-230.

LISPECTOR, Clarice. A Cidade Sitiada. Rio de Janeiro: Editora Rocco. 1998. 204 p.

LYLE, John Tillman. Design for human ecosystems. New York: Van Nostrand, 1985.

LYNCH, Kevin. A imagem da cidade. São Paulo: Martins Fontes. 1997.

MACEDO, Maria Helena de Almeida. A emergência do marketing na política capixaba: comunicação, imagem, símbolo e poder. Dissertação (Mestrado) - Faculdade de História da Universidade Federal do Espírito Santo. Vitória, 2007.

MAGNOLI, Miranda. M. E. Martinelli. Espaços livres e urbanização: 
uma introdução a aspectos da paisagem metropolitana. Tese (Livre-docência) - Faculdade de Arquitetura e Urbanismo, Universidade de São Paulo. São Paulo, 1982.

Em busca de outros espaços livres de edificação. Paisagem e Ambiente: ensaios/ Universidade de São Paulo, Faculdade de Arquitetura e Urbanismo, São Paulo, n. 21, p. 141-159 , 2006. Anual. ISSN 01046098.

MARKUSEN, Ann (2005). Mudança econômica regional segundo o enfoque centrado no ator. In: DINIZ, C. C. e LEMOS, M. B. (org.). Economia e território. Belo Horizonte: Editora da UFMG, 2005.

MARX, Karl e ENGELS, Friedrich Friedrich. O Manifesto do Partido Comunista. Moscou: Edições Progresso Lisboa, 1987.

MASSEY, Doreen. Power-geometry and a progressive sense of place. In: BIRD, J. et al. (eds.) Mapping the futures, local cultures, global change. Londres, Nova York: Routledge. 1993.

MENDES, Constantino C. Brasil policêntrico e planejamento territorial de longo prazo. Boletim Regional. Brasília: Ministério da Integração Nacional, V Edição, maio 2008.

MONTEIRO, Peter Ribon. Vitória: cidade e presépio. Os vazios visíveis da capital capixaba. São Paulo: Annablume, Fapesp; Vitória.: Facitec. 2008.

MORAES, Cícero. Geografia do Espírito Santo. Vitória: Fundação Cultural do Espírito Santo, 1974.

MOREIRA, Antonio Claudio L. Megaprojetos e ambiente urbano: uma metodologia para elaboração do Relatório de Impacto de Vizinhança. 1997. Tese (Doutorado) - Faculdade de Arquitetura e Urbanismo da Universidade de São Paulo, São Paulo, 1997.

MURARI, Luciana. Tudo o mais é paisagem: representações da natureza na cultura brasileira. 2002. Tese (Doutorado) - Departamento de História da Universidade de São Paulo. São Paulo, 2002.

PAIVA, Ricardo Alexandre. Entre o mar e o sertão: paisagem e memória no Centro de Fortaleza. Dissertação (Mestrado) - Faculdade de Arquitetura e Urbanismo da Universidade de São Paulo. São Paulo, 2005.

PAMUK, Orhan. Istambul: memória e cidade. Tradução Sérgio Flaskman. São Paulo: Companhia das Letras, 2007.

PENTEADO, Homero; ALVAREZ, Cristina Engel. Corredores Verdes 
Urbanos: Estudo da viabilidade de conexão das áreas verdes de Vitória. Paisagem e Ambiente. Universidade de São Paulo. Faculdade de Arquitetura e Urbanismo - Anual. São Paulo, n.24 Especial. ENEPEA, 2007. ISSN 01046098.

PRADO, Michele Monteiro. A modernidade e o seu retrato: imagens e representações das transformações da paisagem urbana de Vitória (E.S) - 1890/1950. Dissertação (Mestrado) - Faculdade de Arquitetura da Universidade Federal da Bahia. Salvador, 2002

PRADO, Paulo Paisagem. In: Paulística. Rio de Janeiro: Col. Documentos Brasileiros, n. 152, p. 139-142, 1925.

PREFEITURA MUNICIPAL DE ANCHIETA. Plano Diretor Municipal de Anchieta. Anchieta, 2006. ISSN 01046098.

AGENDA 21 de Anchieta. Anchieta, 2006.

PRONSATO, Sylvia A. Dobry. Arquitetura e paisagem: projeto participativo e criação coletiva. São Paulo: Annablume; Fapesp; Fupam, 2005.

QUEIROGA, Eugênio Fernandes. A megalópole e a praça. Tese (Doutorado) - Faculdade de Arquitetura e Urbanismo da Universidade de São Paulo. São Paulo, 2001.

Por um paisagismo crítico: uma leitura sobre a contribuição de Miranda Magnoli para a ampliação do corpus disciplinar do paisagismo. Paisagem e Ambiente: ensaios / Universidade de São Paulo, Faculdade de Arquitetura e Urbanismo, São Paulo, n.21, p. 55-63, 2006. Anual. ISSN 01046098.

Sistemas de espaços livres urbanos: construindo um referencial teórico. Paisagem e Ambiente: ensaios/ Universidade de São Paulo, Faculdade de Arquitetura e Urbanismo - Anual. São Paulo, n.24, p.81-87, Especial. ENEPEA, 2007. ISSN 01046098.

RADAMBRASIL. Geologia, geomorfologia, pedologia, vegetação e uso potencial da terra. Rio de Janeiro/Vitória: Ministério das Minas e Energia/ SG/Projeto RADAMBRASIL, 1983, Fls. SF. 23-24.

RADAMBRASIL. Levantamento de recursos naturais. Rio de Janeiro/ Vitória: Ministério das Minas e Energia SG/Projeto RADAMBRASIL,1983, Fls. SF. 23-24.

RAFFESTIN, Claude. Por uma geografia do poder. Tradução de Maria 
Cecília França. São Paulo: Ática, 1993.

RAMOS, Aluísio Wellichan. A cidade como negócio: aspectos da atuação do setor imobiliário e da relação público-privado na Barra Funda e na Água Branca (Município de São Paulo) - um exame crítico da operação urbana Água Branca e do projeto 'Bairro Novo'. 2006. Tese (Doutorado) - Faculdade de Filosofia, Letras e Ciências Humanas (FFLCH), Universidade de São Paulo, São Paulo, 2006.

REIS, Nestor Goulart. Notas sobre urbanização dispersa e novas formas de tecido urbano. São Paulo : Via das Artes, 2006.

ROCHLITZ, Rainer (Coord). Habermas: o uso público da razão. Tradução Léa Novaes. Rio de Janeiro: Tempo Brasileiro. 2005.

DESCHAMPS, Marley. Estudo sobre a vulnerabilidade socioambiental na Região Metropolitana de Curitiba. Cadernos Metrópole, n.19. Semestral. ISSN 1517-2422, p.191-219, 2008.

SACHS, Ignacy. Estratégias de Transição para o Século XXI. Para Pensar o Desenvolvimento Sustentável. Bursztyn, M.(org.). São Paulo: Ed. Brasiliense. 1994.

SOROS, George. The worst market crisis in $\mathbf{6 0}$ years. London: Financial Times. 22 jan 2008. Disponível em : <http:// wikipedia.org/wiki/Crise_ econômica 2008-2009>- Acesso em: jan. 2009.

SANDEVILLE JUNIOR, Euler. Patrimônio paisagístico natural e construído. IN: I Encontro sobre Percepção e Conservação Ambiental: a Interdisciplinaridade no Estudo da Paisagem. 28, 29 e 30 de abril de 2004. Rio Claro - SP, Anais... OLAM - Ciência \& Tecnologia, 2004. ISSN 1519-8693.

SANTOS, Milton. Espaço e sociedade. Petrópolis: Vozes, 1979.

Técnica, espaço, tempo: globalização e meio técnico-científicoinformacional. São Paulo: Hucitec, 1994.

Metamorfoses do espaço habitado. São Paulo: Hucitec, 1998.

Por uma outra globalização: do pensamento único à consciência universal. 13. ed. Rio de Janeiro: Record, 2006.

A natureza do espaço: técnica e tempo, razão e emoção. 4.ed. São Paulo: Editora da Universidade de São Paulo, 2008.

SANTOS, Milton; SILVEIRA, Maria Laura. O Brasil: território e socie- 
dade no início do séc. XXI. 7.ed. Rio de Janeiro. Record, 2005.

SARFATI, Gilberto. O terceiro xadrez: como as empresas multinacionais negociam nas relações econômicas internacionais. Tese (Doutorado). Faculdade de Filosofia, Letras e Ciências Humanas (FFLCH), Universidade de São Paulo. São Paulo, 2006.

SHIELDS, R. A truant proximity: presence and absence in the space of modernity. Environment and Planning D: Society and Space, v. 10, 1992.

SHI-

NOHARA, Daniel Yoshio. Parcerias público-privadas: um estudo de casos no Brasil. Dissertação de Mestrado. Faculdade de Economia, Administração e Contabilidade da Universidade de São Paulo (FEA/USP). São Paulo, 2006.

SIMMEL, Georg. The metropolis and mental life; fashion; e the stranger. In:__. On individuality and social forms. Edited and introduced by Donald Levine. Chicago: Chicago University Press, 1971.

SIMÕES, Roberto Garcia. Aterros, mangues e mar: primeiras considerações sobre o problema. Vitória: Fundação Jones dos Santos Neves, 1978.

SOMEKH, Nadia. A luz da cidade: memória urbana e sociedade. In: DIAS, Beatriz (Org.). Um Século de Luz. São Paulo/SP: Scipione, 2001, p. 45-137.

SOUZA, Marcelo Lopes. Mudar a cidade: uma introdução crítica ao planejamento e à gestão urbanos. 4. ed. Rio de Janeiro: Bertrand Brasil, 2006.

SPOSITO, Eliseu Savério. Sobre o conceito de território: um exercício metodológico para a leitura da formação territorial do sudoeste do Paraná. In: RIBAS, A. D; SPOSITO, E. S.; SAQUET, M. A (org.). Território e Desenvolvimento: diferentes abordagens. Francisco Beltrão: Unioeste, 2004.

STRANGE, Susan. States and markets: an introduction to International Political Economy. London: Pinter Publishers, 1988.

TEIXEIRA, Aparecida Netto. Cidade e Siderurgia: A Região Metropolitana de Vitória (ES) e o Complexo Mínero-Siderúrgico. Dissertação (Mestrado) - Faculdade de Arquitetura e Urbanismo da Universidade de São Paulo. São Paulo, 1998.

TEIXEIRA, Elenaldo. O Local e o Global: limites e desafios da participação cidadã. São Paulo: Cortez, 2002.

VEYNE, Paul. Como se escreve a história e Foucault revoluciona a história. Brasília: Universidade de Brasília, 1998. 
WALTZ, Kenneth. Theory of International Politics. Addison- Wesley, Reading.1979.

YÁZIGI, Eduardo et al. (Org.). Turismo e paisagem. São Paulo: Contexto, 2002.

\section{Periódicos}

ABDO FILHO. Construção de siderúrgica de U\$ 3,5 bilhões em Anchieta vai gerar 15 mil empregos no estado. A Gazeta, Vitória, 24 ago.2007. Caderno Economia.

Para $61,7 \%$ dos capixabas, imóveis valem menos que o valor cobrado. A Gazeta, Vitória, 30 out. 2007, p.13.

Indústria do petróleo vai contratar 4,7 mil trabalhadores em dois anos. A Gazeta, Vitória, 22 nov. 2007. Economia.

Novos bairros surgem com a construção de megacondomínios. A Gazeta, Vitória, 20 nov. 2007. Economia, p.13.

ABDO FILHO: FELIZ, Claúdia. Crescimento transforma. A Gazeta, Vitória, 16 dez. 2007. Cidades, p.22.

. Municípios vizinhos de Anchieta vão sentir o impacto das obras. A Gazeta, Vitória, 16 dez. 2007. Caderno Cidades, p.23.

Comércio fatura alto. A Gazeta, Vitória, 16 dez. 2007. Cidades, p.24.

Da Pesca às obras. A Gazeta, Vitória, 16 dez. 2007. Cidades, p.26.

. Turismo e meio ambiente em busca de soluções. A Gazeta, Vitória. 16 dez. 2007. Economia.

BELLO, Elisângela. Faltam fiscais em áreas verdes do Estado. A Gazeta, Vitória, 12 nov. 2007, p. 4.

BRIDI, Rita. Aracruz vai investir R \$ 3 bilhões em sua quarta fábrica no Estado. A Gazeta, Vitória, 27 abr. 2007, p.15.

Ubu poderá abrigar filial brasileira da maior siderúrgica da China.

A Gazeta, Vitória, 11 jul. 2007. Economia, p.13. 
Bancada pede que Petrobrás faça obra em Barra do Riacho. A Gazeta, Vitória, 13 jul. 2007, p.15.

Com a vinda de indústrias, Estado ganhará mais estradas e portos. A Gazeta, Vitória, 29 jul. 2007, p.24.

Agência leiloa petróleo no Estado a partir de R \$35 mil. A Gazeta, Vitória, 4 out. 2007, p.17.

. Mittal quer fazer do Estado a base do grupo na América Latina. A Gazeta, Vitória, 8 dez. 2007. Economia, p. 31.

Plano prevê R \$ 900 milhões para energia eólica no Estado. A Gazeta, Vitória, 17 mar. 2008, p.21.

. Samarco investirá US\$2 bi em nova usina, porto e mineroduto. A Gazeta, Vitória, 19 abr. 2008. Economia, p.20.

. Estado receberá investimentos de R $\$ 55$ bi até 2012. A Gazeta, Vitória, 7 set. 2008. Economia, p.19.

BRIDI, Rita, ZANDONADI, Denise. Cidades perdem R $\$ 400$ milhões com reforma tributária. A Gazeta, Vitória, 6 mar. 2008, p.15.

CARPANEDO, Flávia. Ubu: capacidade ampliada em 4 milhões de toneladas. A Gazeta, Vitória, 8 dez. 2007. Economia, p. 29,

Findes capacitará 3 mil trabalhadores por ano em Anchieta. A Gazeta, Vitória, 14 dez. 2007. Economia, p. 28.

CUSTÓDIO, Zenilton. Fogo destrói mata no Parque de Itaúnas há duas semanas. A Gazeta, Vitória, 12 nov. 2007, p. 6.

FERNANDES, Vilmara. Governo planeja 7 barragens para atender a siderúrgica. A Gazeta, Vitória, 31 out. 2008. Economia, p.15.

FERRAÇO, Vera; QUINTINO, Felipe. Criada por lei em 1995, Região Metropolitana não deslancha. A Gazeta, Vitória, 22 nov. 2007. Suplemento Política, p.15.

GARCIA, Lucia. Por trás dos investimentos, riqueza já está no ar no Estado. A Gazeta, Vitória, 10 jun. 2007. Caderno Economia.

Cidades se transformam num grande canteiro de obras. A Gazeta, Vitória, 10 jun. 2007, p.22. 
Mercado aquecido: valor dos imóveis cresceu até $40 \%$ no ano. A Gazeta, Vitória. $1^{\circ}$ jul. 2007. Suplemento Imóveis.

Estado será o quarto maior mercado imobiliário do país em três anos. A Gazeta, Vitória. 12 set. 2007. Caderno Economia.

GONÇALVES, Rodrigo. Ferrous inicia projeto de porto e mineradora no Sul. A Gazeta, Vitória, 28 maio 2009. Economia, p.15.

HEES, André. Chineses confirmam usina siderúrgica de R $\$ 10$ bi no Sul. A Gazeta. Vitória, 9 out. 2008, p.21.

MENDONÇA, Maurílio. Centro de referência do Trabalho por enquanto fica só nas placas. A Gazeta, Vitória, 9 jun. 2007, p. 6.

MURTA, Milena. Construção civil, bares e hotéis são campeões em contratações. A Gazeta, Vitória, 19 out. 2007. Caderno Economia, p.15.

NOBRE, Karina. Anchieta vai concentrar vários empreendimentos econômicos. A Gazeta, Vitória, 10 jan. 2008.

SIMÕES, Roberto. Rotas do Litoral Sul. A Gazeta. Vitória, 24 jul. 2007. Opinião. Primeiro Caderno.

SOUZA, Daniela. Morros da Enseada já sentem os efeitos de expansão imobiliária. A Gazeta, Vitória, 21 out. 2007, p.4.

SILVA, Elaine. Nem Kennedy, nem Itapemirim. Baosteel deve deixar o Estado. A Gazeta, Vitória, 4 dez 2008. Economia, p.19.

VARGAS, André. Chineses querem bairro com 1.150 casas em Anchieta. A Gazeta, Vitória, 21 set. 2007, p.18.

VIEIRA, Elaine. Moradores vencem luta, e Vale terá que controlar pó de minério. A Gazeta, Vitória, 15 jun. 2007, Cidades, p.4.

ZANDONADI, Denise. Governo acende sinal amarelo para exploração de gás no Estado. A Gazeta, Vitória, 9 maio 2007, p.15.

Petrobrás descobre mais gás no Norte do Espírito Santo. A Gazeta, Vitória, 10 maio 2007, p.19.

Petrobras começa a dividir reinado do petróleo no Estado. A Gazeta, Vitória, 10 jun. 2007. Economia, p.26. 
. ANP vende 18 blocos de petróleo no Estado. A Gazeta, Vitória, 25 jul. 2007, p.19.

Estado receberá navios gigantes no porto mais profundo do país. A Gazeta, Vitória, 25 ago. 2007, p.15.

. Agência explica cálculo do dinheiro do petróleo. A Gazeta, Vitória, 25 ago. 2007, p.17.

- Seis sondas buscam novos campos de petróleo no Estado. A Gazeta, Vitória, 30 ago. 2007, p.17.

. Mais petróleo e mais dinheiro para o Estado. A Gazeta, Vitória,16 out. 2007, p.24.

. Exploração começou em 1957 em São Mateus. A Gazeta, Vitória, 16 out. 2007 , p. 24 .

Siderúrgica, porto e ferrovia de R $\$ 10$ bi: o maior projeto do país. A Gazeta, Vitória, 4 out. 2007. Economia.

Economia aquecida e gestão tiram municípios do vermelho. A Gazeta, Vitória, 7 out. 2007. Economia, p.26.

. Produção de reserva gigante de Petróleo começará pelo Estado. A Gazeta, Vitória, 9 nov. 2007, p.15.

Curso de petróleo deixa 440 alunos sem bolsa e qualificação. A Gazeta, Vitória, 22 fev. 2008, p.15.

Empresa inicia construção de plataforma. A Gazeta, Vitória, 22 fev. 2008, p.15.

Governo já prepara estudo ambiental para pólo de Anchieta. A Gazeta, Vitória, 26 junho 2008, Economia, p.15.

Pólo em Ubu: ambientalistas alertam para falta de água. A Gazeta, Vitória, 25 junho 2008. Economia, p.15.

Sul ganha Mineradora e Porto de US\$2,7bilhões. A Gazeta, Vitória, $1^{\circ}$ ago. 2008. Economia, p.15.

Sobra pó, falta água. E pólo de Anchieta fica sem siderurgia. A Gazeta, Vitória, 28 nov.2008, p.1.

.Governo retira siderúrgica de Ubu por poluição e falta d'água. A 
Gazeta, Vitória, 28 nov.2008, p.15.

Governo troca aço por petróleo em Anchieta. A Gazeta, Vitória, 29 nov.2008, p.1 e p.17.

Pólo de Anchieta: siderurgia dará espaço ao petróleo. A Gazeta, Vitória, p.17, 29 nov.2008.

Siderúrgica no sul não sai do papel sem porto e ferrovia. A Gazeta, Vitória, 6 ago. 2009. Economia, p.15.

Siderúrgica da Vale em Ubú vai criar 18 mil empregos. A Gazeta, Vitória, 28 ago. 2009. Economia, p.15.

- Vale vai investir R\$9,4 bi em siderúrgica e porto. A Gazeta, Vitória, 29 ago. 2009. Economia, p.15.

\section{Sites eletrônicos}

www.anchieta.es.gov.br

www.CST.com.br/perfil/história

www.brasil.gov.br/PAC/estados.

www.es-acao.org.br/esemacao/esemacao/missao/missao.php

www.es.gov.br/site/turismo/rota sol moqueca.

www.samarco.com.br

www.midiaindependente.org

http://www.aracruz.com.br

Vale do Rio Doce e chinesa Baosteel iniciam projeto siderúrgico no ES.

Disponível em: <www.uol.com.br>. Acesso em: 3 out. 2007. 